\title{
Advances in Research on Mineral Resources, 1994
}

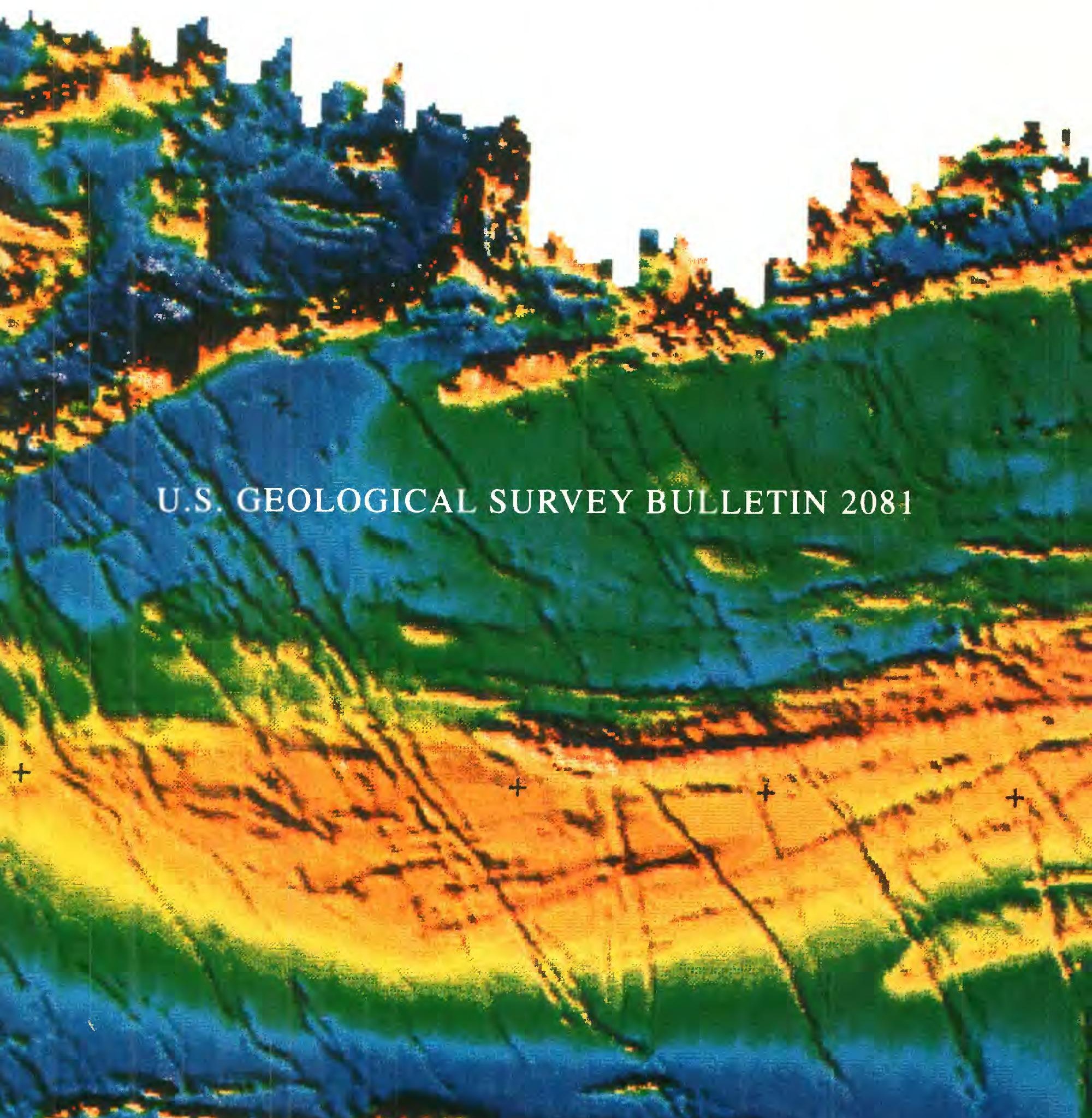


Cover. Part of a color shaded-relief aeromagnetic map of north-central Minnesota. Color changes represent broad changes in magnetic field strength. The warm colors (red, orange, and yellow) represent areas of magnetic field highs; the cool colors (green, blue, and purple) represent magnetic field lows.

[From Horton, R.J., Day, W.C., and Bracken, R.E., Aeromagnetic survey of north-central Minnesota, chap. T of Scott, R.W., Jr., Detra, P.S., and Berger, B.R., eds., Advances Related to United States and International Mineral Resources: Developing Frameworks and Exploration Technologies: U.S. Geological Survey Bulletin 2039, p. 203] 


\section{Advances in Research on Mineral Resources, 1994}

Edited by Byron R. Berger

U.S. GEOLOGICAL SURVEY BULLETIN 2081

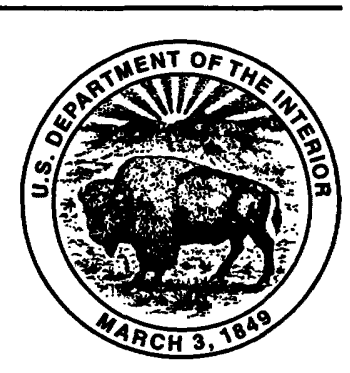

UNITED STATES GOVERNMENT PRINTING OFFICE, WASHINGTON : 1994 


\title{
U.S. DEPARTMENT OF THE INTERIOR BRUCE BABBITT, Secretary
}

\author{
U.S. GEOLOGICAL SURVEY \\ Gordon P. Eaton, Director
}

\author{
Published in the Central Region, Denver, Colorado \\ Manuscript approved for publication June 17, 1994 \\ Edited by Richard W. Scott, Jr. \\ Photocomposition by Shelly A. Fields \\ Cover design by Art Isom \\ Additional assistance from Branch of Geochemistry: \\ Additional proofing and review by Pamela S. Detra \\ Graphics prepared by Dick Walker \\ Assistance with manuscript preparation by Margo Johnson \\ and Barbara Ramsey
}

For sale by U.S. Geological Survey, Map Distribution

Box 25286, MS 306, Federal Center

Denver, CO 80225

\begin{abstract}
Any use of trade, product, or firm names in this publication is for descriptive purposes only and does not imply endorsement by the U.S. Government.
\end{abstract}

\section{Library of Congress Cataloging-in-Publication Data}

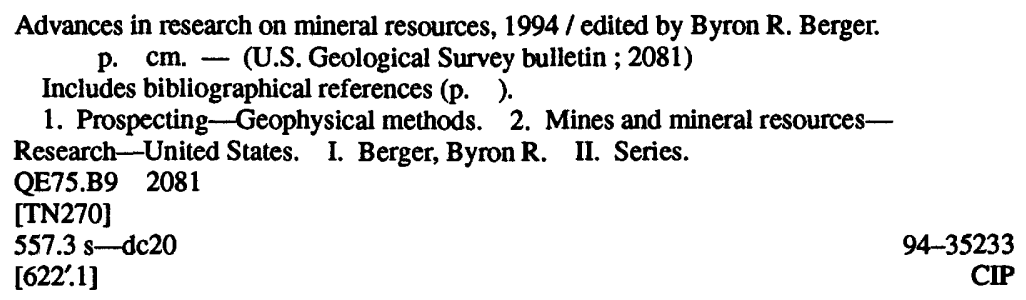




\section{CONTENTS}

[Letters designate chapters]

Introduction: USGS-An International Perspective on Mineral Resources and Resource Technologies

By Byron R. Berger.

A. $\mathrm{Pb}$ Isotope Compositions of the Bandelier Tuff, Valles Caldera, Jemez

Mountains, New Mexico-An Active Geothermal System Associated with Mo Mineralization

By Robert A. Ayuso and Robert L. Smith

B. Implications of Eocene Through Miocene Ages for Volcanic Rocks, Snowstorm Mountains and Vicinity, Northern Nevada By Alan R. Wallace and E.H. McKee

C. ${ }^{40} \mathrm{Ar} /{ }^{39} \mathrm{Ar}$ and U-Th-Pb Ages Associated with Base- and Precious-Metal Deposits in Central Idaho

By Karl V. Evans, Lawrence W. Snee, and Robert E. Zartman.

D. Geology and Mineral Deposits in the Terrill Mountains Area, Holy Cross

District, Churchill County, Nevada

By Stephen G. Peters, Richard F. Hardyman, and Katherine A. Connors

E. Time-pH- $\mathrm{f}_{\mathrm{O}_{2}}$ Paths of Hydrothermal Fluids and the Origin of Quartz-Alunite-Gold Deposits

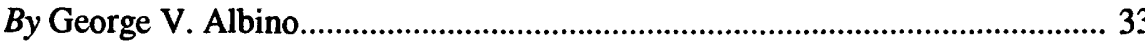

F. Remote-Sensing Spectral Properties of Selected Industrial

Minerals and Ores

By James K. Crowley

G. Geochemical Exploration Studies in the Portuguese Pyrite Belt

By David J. Grimes and Delfim de Carvalho 



\title{
INTRODUCTION
}

\section{USGS-AN INTERNATIONAL PERSPECTIVE ON MINERAL RESOURCES AND RESOURCE TECHNOLOGIES}

\author{
By Byron R. Berger ${ }^{1}$
}

Geographic landscapes change only slowly, but political and economic landscapes can change abruptly and unexpectedly. The geological sciences are contributors to changes in these landscapes, but they also serve as a source of information on which an informed polity may base decisions on behalf of a society. The U.S. Geological Survey (USGS) is dedicated to providing information for the public good in all aspects of the geological sciences, including mineral resources.

Mineral resources are a part of the geosciences that impact all aspects of a society from national economic security to national defense to land-use decisions to health and welfare-these impacts affect not just humans but all other animals as well as all flora. Minerals are an essential part of the well-being of both a society and the Earth. They serve as the basis for infrastructure, technological innovation and development, economic policies, national defense, and national economic security; they are also essential to informed decisions on environmental risk and environmental tradeoffs in any decision-making process.

The USGS provides mineral resource information, knowledge, and technical analyses from highly trained scientists with broad-ranging technical skills to Federal, State, and local governments; industries; schools and universities; and the general public of the United States. It also engages in cooperative studies with other countries and their institutions to provide training, exchange information and understanding, and attack important scientific problems. This Bulletin, Advances in research on mineral resources, 1994, reports progress on some of the current domestic and international research activities of the Office of Mineral Resources, Geologic Division of the USGS.

${ }^{1}$ U.S. Geological Survey, Mail Stop 973, P.O. Box 25046, Denver Federal Center, Denver, CO 80225.

\section{ESTABLISHING A GEOLOGIC FRAMEWORK FOR MINERAL DEPOSITS}

Since the emergence of economic geology as a recognized subdiscipline within the earth-science research community within the last century, there has been heated debate about the role of igneous processes in the genesis of deposits that are spatially associated with intrusions and volcanic rocks. Do the metals in most deposits come from magmas, or is the magma merely a partial contributor or simply a heat engine? Even the use of sophisticated new technologies in the post-World War II era has not caused the issue to wither. Although there are stable-isotope methodologies to fingerprint probable water sources and radiogenic methodologies that reveal the source of some metals (and most deposits and rocks can now be dated with high precision), the debate continues. Lead, for example, in some epizonal, polymetallic, mineral deposits is isotopically indistinguishable from coeval igneous rocks, whereas in other, ostensibly identical, rock types, it more closely reflects the composition of basement crystalline rocks than do coeval igneous rocks.

In the first chapter in this volume, Ayuso and Smith (chapter A) use lead isotopes to examine the behavior of heavy metals in a shallow, siliceous magma chamber. Their results show that the lead isotopic composition of different magma batches from a presumed single reservoir may vary considerably-a fact that has important implications for the use of isotopes in ore-genesis studies.

The timing of mineralization is of considerable importance in exploration as well as mineral-resource-appraisal studies. Wallace and McKee (chapter B) and Evans and others (chapter C) both present data of considerable import to two areas in the Western United States. Wallace and McKee show that both late Eocene and middle Miocene volcanism in northern Nevada blanketed larger areas than has been previously recognized. Base- and precious-metal 
mineralization is associated regionally with both periods of volcanic activity-therefore, their work substantially enlarges the terrain that is permissive for mineral occurrences. Similarly, Evans and others have shown there to be a period of Late Cretaceous mineralization in Idaho in a region thought previously to contain only Tertiary mineralization.

Geologic mapping by Peters and others (chapter D) in western Nevada has established a geologic and structural context for epithermal mineralization in the Holy Cross mining district. This work permits an evaluation of the mineral resource potential at Holy Cross relative to nearby producing mines in the Rawhide and Santa Fe districts and contributes to the general volcanic stratigraphy of the region.

\section{DEVELOPING A CONCEPTUAL FRAMEWORK FOR ORE-DEPOSITING PROCESSES}

Descriptive, geochemical, and geophysical data are compiled from numerous mineral deposits and mining districts and assembled into models that serve as backbones for exploration and resource-assessment activities. Marrying experimental data and descriptive data from actual deposits is a difficult task in modeling. Albino (chapter E) attacks this problem by examining the temporal relations between different deposits of a certain style of gold mineralization and postulates that these deposits are derived through the mobilization of metals from a previously existing deposit. If this conceptual model is correct, then there are important implications for both exploration and assessment.

\section{DEVELOPING AND TESTING TECHNOLOGIES FOR MINERAL RESOURCE ASSESSMENT AND EXPLORATION}

The development and use of appropriate and state-ofthe-art technologies is integral to mineral resource assessments and exploration. In chapter F, Crowley shows the results of laboratory experiments designed to evaluate the utility of remotely sensed spectral data in detecting industrial minerals and ores. His results are encouraging for the use of new airborne and satellite technologies in the search for and assessment of important industrial commodities.

When technologies have been developed that appear to be useful, performance testing under normal field conditions is valuable both to document the conditions under which a technology is useful and to transfer that technology to other users. Grimes and de Carvalho (chapter $\mathrm{G}$ ) tested a variety of exploration geochemical techniques over wholly unexposed, massive sulfide mineralization in the Portuguese Pyrite Belt. They not only successfully found indications of unexposed mineralization with some techniques, but they also delimited the optimum conditions under which to apply these techniques. Their findings will be of considerable value to additional exploration in this part of Portugal and to future work in similar climatological and geologic environments. 


\title{
CHAPTER A
}

\section{$\mathrm{Pb}$ ISOTOPE COMPOSITIONS OF THE BANDELIER TUFF, VALLES CALDERA, JEMEZ MOUNTAINS, NEW MEXICO_AN ACTIVE GEOTHERMAL SYSTEM ASSOCIATED WITH Mo MINERALIZATION}

\author{
By Robert A. Ayuso ${ }^{1}$ and Robert L. Smith ${ }^{2}$
}

\begin{abstract}
Two Pleistocene eruptions, approximately 350,000 years apart, deposited the Otowi and Tshirege Members of the Bandelier Tuff. These members were associated with the collapse of the Toledo and Valles calderas, and each caldera had a complex post-collapse history of rhyolitic volcanism, which included the Cerro Toledo Rhyolite and the Valles Rhyolite. $\mathrm{Pb}$ isotope determinations of 78 whole rocks and K-feldspars from the Bandelier Tuff and associated rocks indicate that $\mathrm{Pb}$ isotope compositions changed significantly during evolution of the silicic rocks. The Otowi Member of the Bandelier Tuff is less radiogenic than the Tshirege (e.g., ${ }^{206} \mathrm{~Pb} /{ }^{204} \mathrm{~Pb}=17.816-17.853$ for the Otowi and 17.938-18.003 for the Tshirege), and the Cerro Toledo Rhyolite has intermediate values $\left({ }^{206} \mathrm{~Pb} /{ }^{204} \mathrm{~Pb}=\right.$ 17.823-18.003). In the Valles Rhyolite, older domes $\left({ }^{206} \mathrm{~Pb} /{ }^{204} \mathrm{~Pb}=17.925-18.010\right)$ overlap the Tshirege Member, but the younger Valles domes $\left({ }^{206} \mathrm{~Pb} /{ }^{204} \mathrm{~Pb}=\right.$ 17.686-17.745) are the least radiogenic in the BandelierToledo-Valles magma system. $\mathrm{Pb}$ isotope values of pre-Bandelier Quaternary basalts and intra-Bandelier basaltic andesites $\left({ }^{206} \mathrm{~Pb} /{ }^{204} \mathrm{~Pb}=17.549-17.891\right)$ overlap the Bandelier Tuff; pre-Bandelier andesites, dacites, rhyodacites, and rhyolites, which include potential parents or contaminants of the Bandelier Tuff, have $\mathrm{Pb}$ isotope compositions that bracket the entire magmatic system. The Bandelier Tuff originated as a mixture of mantle-derived rocks and crustally derived melts; the magma chamber grew by replenishment or mixing of chemically variable magma at the bottom of the chamber
\end{abstract}

${ }^{1}$ U.S. Geological Survey, Mail Stop 954, National Center, 12201 Sunrise Valley Drive, Reston, VA 22092-0001. 95821 . (open system) and was influenced by fractional crystallization coupled with assimilation of isotopically different wallrocks. Volcanic eruptions in such periodically discharged systems may partially remove magmas from the roof of the magma chamber whose isotopic and other geochemical signatures differ from those stored at lower depths-this process may give rise to isotopically zoned plutonic rocks.

\section{INTRODUCTION}

This paper reports preliminary results of an ongoing isotopic study of the Bandelier Tuff and associated igneous rocks in the Jemez Mountains (fig. 1) in an effort to better understand the genesis of compositionally zoned magmatic systems and to improve our knowledge of isotopic variations in an active hydrothermal system. We have established the range of $\mathrm{Pb}$ isotopic compositions of rhyolitic ash-flow sheets of the Bandelier Tuff (Otowi Member and Tshirege Member); Cerro Toledo Rhyolite; Valles Rhyolite; older and contemporaneous mafic, intermediate, and rhyolitic rocks; and Proterozoic basement (fig. 2; table 1).

The processes associated with caldera formation and zoned magma chambers have been documented in the Jemez Mountains, and the Valles caldera represents a classic example of an intracontinental resurgent caldera (Smith and Bailey, 1966, 1968; Smith and others, 1970; Gardner and others, 1986; Heiken and others, 1986; Self and others, 1986, 1988). Various attempts have also been made to refine the geochemical constraints associated with the evolution of Bandelier magmas (e.g., Smith, 1979; Macdonald and Smith, 1988; Turbeville and Self, 1988; Loeffler and others, 1988; Stix and others, 1988; Spell and Kyle, 1989; Skuba and Wolff, 1989; Ayuso and Smith, 1989; Stix and Gorton, 1990; Hervig and Dunbar, 1992). The Valles caldera was 


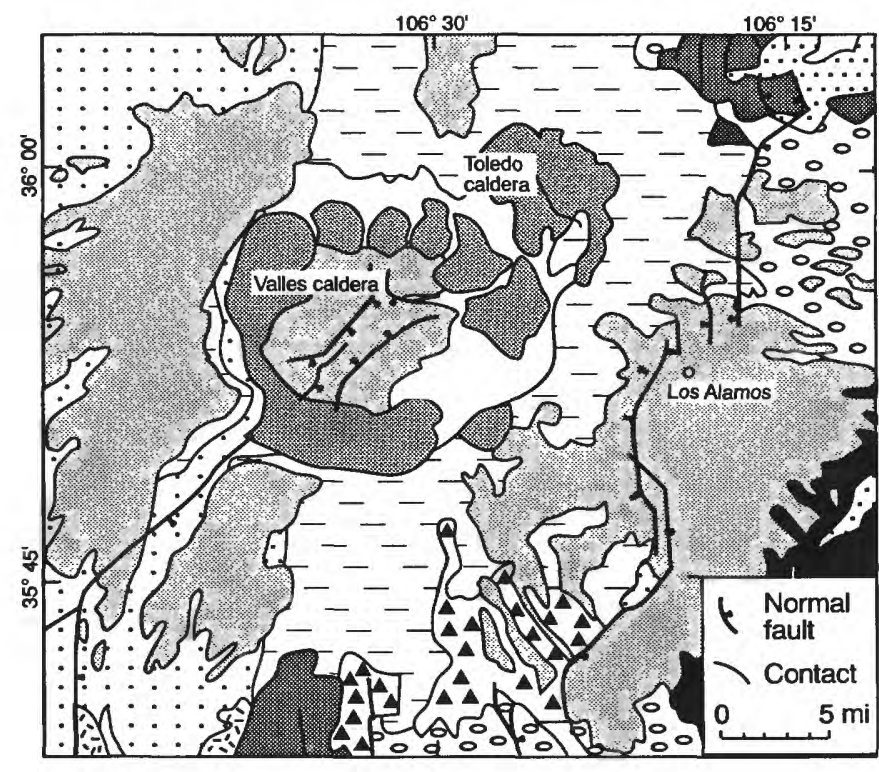

Explanation

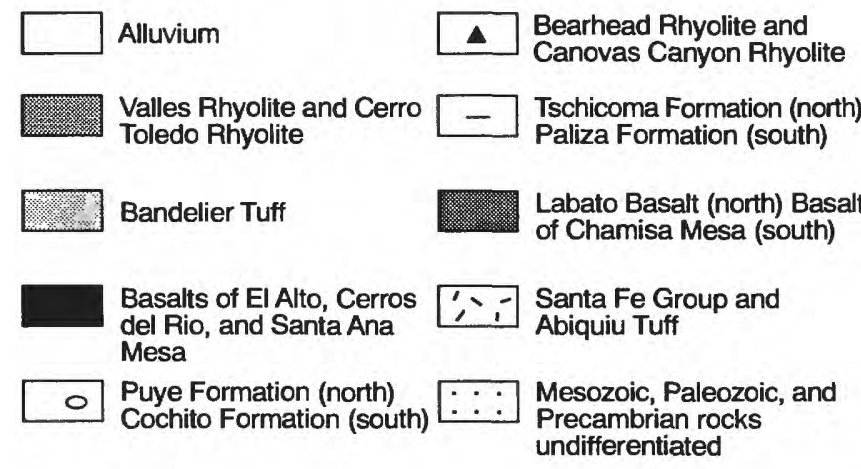

Figure 1. Generalized map of the Valles caldera, New Mexico (from Smith and others, 1970).

also selected as a site for deep drilling for the continental scientific drilling program (Goff and Gardner, 1988). Moreover, the Valles caldera is an active hydrothermal system associated with sub-ore-grade molybdenum mineralization, as well as $\mathrm{Cu}, \mathrm{Pb}, \mathrm{Zn}, \mathrm{Mn}, \mathrm{Bi}, \mathrm{Te}$, and $\mathrm{Ag}$ minerals (Hulen and others, 1987). A better understanding of the isotope variations in active hydrothermal systems and their ore deposits could well result in an increased ability to identify fossil ore deposits associated with silicic calderas.

\section{CHEMICAL ZONING IN SILICIC SYSTEMS}

Isotopic studies have been particularly useful in helping to constrain mechanisms leading to chemical zoning in silicic magma chambers. For example, variations in ${ }^{87} \mathrm{Sr} /{ }^{86} \mathrm{Sr}$ values within individual ash-flow sheets were ascribed to assimilation of country rock (Noble and Hedge, 1969), and variations in O isotopes were used to detect a gradually increasing component of meteoric ground water during evolution of a volcanic complex (Lipman and Friedman, 1975). In order to explain a trend of increasing ${ }^{87} \mathrm{Sr} /{ }^{86} \mathrm{Sr}$ values toward the roof of a magma chamber, a convection-driven, liquid-state differentiation mechanism has also been proposed (Hildreth, 1979). In many ash-flow tuffs, isotopic zonation is monotonic, and significant assimilation may occur in the roof zones of magma chambers (e.g., Tegtmeyer and Farmer, 1989; Johnson, 1989; Johnson and others, 1990). However, in some cases $\mathrm{Sr}, \mathrm{O}$, and $\mathrm{Nd}$ isotopic data were interpreted to indicate negligible contamination of magma (Halliday and others, 1984; 1989). Our results on the Bandelier Tuff system demonstrate that $\mathrm{Pb}$ isotopic variations are cyclic, probably reflecting the effects of magma recharge, mixing, fractionation, and assimilation of wallrocks (Ayuso and Smith, 1989).

\section{THE BANDELIER TUFF AND RELATED ROCKS}

The Bandelier Tuff consists of a lower member (Otowi, $1.45 \mathrm{Ma}$, about $300 \mathrm{~km}^{3}$ in volume) and an upper member (Tshirege, $1.12 \mathrm{Ma}$, about $300 \mathrm{~km}^{3}$ in volume) (Smith and Bailey, 1966, 1968; Doell and others, 1968; Izett and others, 1981). The beginning of magmatic activity in the area, however, predates the Bandelier Tuff perhaps by at least as much as 10 m.y. (Bailey and others, 1969; Self and others, 1986; Gardner and others, 1986). The Otowi Member was erupted to form the Toledo caldera, followed by eruption of the Tshirege Member, which formed the Valles caldera. The Cerro Toledo Rhyolite, consisting of high-silica rocks, was erupted from the Toledo caldera and stratigraphically occurs between the Otowi Member and the Tshirege Member of the Bandelier Tuff. The Valles Rhyolite is also a high-silica rhyolite and was erupted after the collapse of the Valles caldera. The older Valles Rhyolite domes span from about $1.18 \mathrm{Ma}$ to $0.75 \mathrm{Ma}$ (Izett and others, 1981), and their age generally depends on the location of individual domes (from older to younger, Cerro del Medio, Abrigo, Santa Rosa, and Seco); the younger Valles domes and flows (San Antonio, South Mountain, Battleship Rock, and Banco Bonito) are $<0.73$ Ma (Izett and others, 1981). The boundary between the resurgent dome (Redondo Peak) and the western ring-fracture marks the strongest hydrothermal activity at the surface, and it is where investigation of a core hole documented fractured and quartz sericitized tuff containing molybdenite, as well as anomalous enrichment in lead, zinc, and silver (Hulen and others, 1987).

The Otowi Member consists of a basal air-fall tuff that originated from the top of the magma chamber and ash flows that originated from deeper in the magma chamber (Smith and Bailey, 1966). Older volcanic rocks, Proterozoic granitic basement, and Proterozoic metamorphic rocks are the predominant xenoliths. Five subunits in the Tshirege Member 

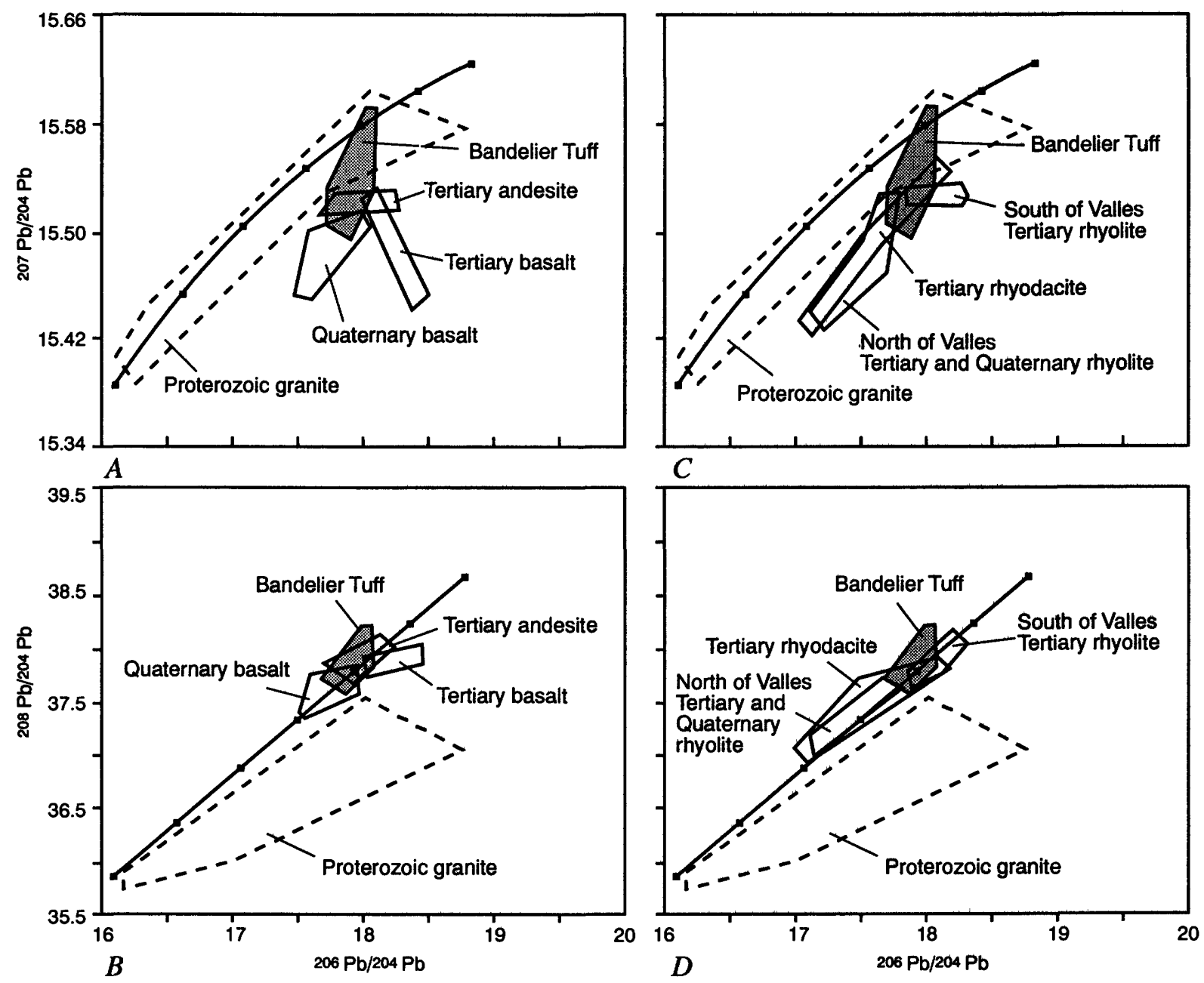

Figure 2. $\mathrm{Pb}$ isotope compositions in the Jemez Mountains, New Mexico. Data for Proterozoic granites, Tertiary basalt and andesite, Quaternary basalt, and Bandelier Tuff magma system: $A,{ }^{206} \mathrm{~Pb} /{ }^{204} \mathrm{~Pb}$ vs. ${ }^{207} \mathrm{~Pb} /{ }^{204} \mathrm{~Pb} ; B,{ }^{206} \mathrm{~Pb} /{ }^{204} \mathrm{~Pb}$ vs. ${ }^{208} \mathrm{~Pb} /{ }^{204} \mathrm{~Pb}$. Data for Tertiary rhyodacite, Quaternary rhyolites, and Bandelier Tuff magma system: $C,{ }^{206} \mathrm{~Pb} /{ }^{204} \mathrm{~Pb}$ vs. ${ }^{207} \mathrm{~Pb} /{ }^{204} \mathrm{~Pb} ; D$, ${ }^{206} \mathrm{~Pb} /{ }^{204} \mathrm{~Pb}$ vs. ${ }^{208} \mathrm{~Pb} /{ }^{204} \mathrm{~Pb}$. Two-stage $\mathrm{Pb}$ evolution curve (solid line) of Stacey and Kramers (1975) is shown for reference and is graduated at $250-\mathrm{Ma}$ intervals.

are recognized. Quartz is found throughout Tshirege, but it is rare in the late, erupted ash flows; abundances of sanidine, clinopyroxene, fayalite, orthopyroxene, magnetite, and ilmenite vary consistently from the bottom to the top. Trace amounts of zircon, apatite, chevkinite, and allanite are also present.

The Bandelier Tuff consists predominantly of high-silica (76-77 percent) rhyolite except for the late eruptives of the Tshirege Member, which have $\mathrm{SiO}_{2}=72$ percent (Smith, 1979). Trace element contents change systematically within each member of the Bandelier Tuff. Lithophile trace elements (e.g., Nb, Ta, Th, etc.) decrease up section, and compatible and ferromagnesian elements (e.g., $\mathrm{Eu}, \mathrm{Co}, \mathrm{Cr}, \mathrm{Sc}$, etc.) increase up section. These variations were interpreted as evidence that the chamber was chemically zoned and that the chemical gradients existed in bulk rock, crystals, and glass in the liquid prior to the formation of the erupted phenocryst gradient (Smith, 1979).

\section{ANALYTICAL TECHNIQUES}

A total of 78 samples of the Bandelier Tuff and associated rocks were analyzed in this study; table 1 summarizes the results. The majority of whole-rock samples from the Bandelier Tuff were obtained from nonwelded vitric pumice blocks. Samples of basalts, andesites, dacites, and rhyolites included pumice, obsidian, perlite, and crystallized rocks. Kfeldspar separates were made from pumice fragments in the Bandelier Tuff and from Proterozoic granitic rocks. $\mathrm{Pb}$ was concentrated using standard $\mathrm{HBr}$ chemistry, and the $\mathrm{Pb}$ isotope values were measured using a 12-inch NBS-type mass spectrometer and a Finnigan MAT 262 multicollector mass spectrometer at the U.S. Geological Survey, Reston, Va. Procedural blanks during the course of this study were $<0.5$ ng and thus are negligible relative to the measured data. The $\mathrm{Pb}$ determinations have a maximum total analytical uncertainty of about 0.1 percent at the 95 percent level on the basis 
Table 1. $\mathrm{Pb}$ isotopic ranges of 78 samples from the Bandelier Tuff and associated rocks, Jemez Mountains, New Mexico.

[n, number]

\begin{tabular}{|c|c|c|c|}
\hline \multirow[b]{2}{*}{ Unit } & \multicolumn{3}{|c|}{$\mathrm{Pb}$ isotopic ratios } \\
\hline & ${ }^{206} \mathrm{~Pb} /{ }^{204} \mathrm{~Pb}$ & ${ }^{207} \mathrm{~Pb} /{ }^{204} \mathrm{~Pb}$ & ${ }^{208} \mathrm{~Pb} /{ }^{204} \mathrm{~Pb}$ \\
\hline \multicolumn{4}{|c|}{ Proterozoic granites $(n=18)$} \\
\hline Whole rock & $17.074-18.589$ & $15.477-15.578$ & $36.030-37.028$ \\
\hline K-feldspar & $16.261-16.749$ & $15.411-15.430$ & $35.801-36.040$ \\
\hline \multicolumn{4}{|c|}{ Pre-Bandelier volcanic rocks $(\mathrm{n}=\mathbf{2 0})$} \\
\hline \multicolumn{4}{|l|}{ Tertiary } \\
\hline Basalt $^{1}$ & $18.027-18.340$ & $15.460-15.527$ & $37.754-37.860$ \\
\hline Andesite $^{2}$ & $17.767-18.099$ & $15.524-15.528$ & 37.613-37.972 \\
\hline Dacite $^{3}$ & $17.124-18.075$ & $15.435-15.546$ & 36.988-37.737 \\
\hline Rhyolite $^{4}$ & $17.897-18.197$ & $15.529-15.531$ & $37.616-37.935$ \\
\hline \multicolumn{4}{|l|}{ Quaternary } \\
\hline Basalt $^{5}$ & $17.549-17.891$ & $15.464-15.512$ & $37.375-37.690$ \\
\hline Rhyolite $^{6}$ & $17.192-17.862$ & $15.440-15.546$ & $37.019-37.695$ \\
\hline \multicolumn{4}{|c|}{ Bandelier Tuff-Cerro Toledo-Valles magmatic system $(n=40)$} \\
\hline Precursor $^{7}$ & $17.805-17.862$ & $15.520-15.546$ & $37.639-37.695$ \\
\hline \multicolumn{4}{|l|}{ Otowi } \\
\hline Early & $17.816-17.837$ & $15.497-15.504$ & $37.560-37.601$ \\
\hline Late & $17.831-17.853$ & $15.516-15.534$ & $37.648-37.699$ \\
\hline \multicolumn{4}{|l|}{ Cerro Toledo } \\
\hline Early & $17.823-17.828$ & $15.511-15.512$ & $37.604-37.607$ \\
\hline Late & $17.980-18.003$ & $15.598-15.627$ & $37.993-38.092$ \\
\hline \multicolumn{4}{|l|}{ Tshirege } \\
\hline Early & $17.938-17.957$ & $15.538-15.570$ & $37.807-37.866$ \\
\hline Late & $17.969-18.003$ & $15.545-15.577$ & $37.838-37.930$ \\
\hline \multicolumn{4}{|l|}{ Valles } \\
\hline Early & $17.925-18.010$ & $15.557-15.570$ & $37.920-37.990$ \\
\hline Late & $17.686-17.745$ & $15.528-15.529$ & $37.626-37.728$ \\
\hline
\end{tabular}

${ }^{1}$ Basalts from Lobato and Chamisa Mesa.

${ }^{2}$ Andesites from Paliza Canyon and Tschicoma Formations.

${ }^{3}$ Dacites and rhyodacites from Tschicoma Formation.

${ }^{4}$ Rhyolites from Canovas Canyon and Bearhead Formations.

${ }^{5}$ Basalts from Totavi and El Alto.

${ }^{6}$ Rhyolites from El Rechuelos Formation.

${ }^{7}$ San Diego Canyon ash flows from precursor Bandelier Tuff (Smith, 1979).

of replicate analyses and accepted values of NBS 981 and NBS 982 standards. A more detailed description of the analytical procedures is given in Ayuso and others (1988). The $\mathrm{Pb}$ data were treated according to the scheme outlined by Ludwig (1988).

\section{RESULTS}

\section{BANDELIER TUFF SYSTEM}

The $\mathrm{Pb}$ isotopic range of the Bandelier Tuff magmatic system is relatively restricted compared to other volcanic rocks from the Jemez Mountains (Ayuso and Smith, 1989) (fig. 2). $\mathrm{Pb}$ isotopic values in the Bandelier Tuff plot for the most part below the average crust $\mathrm{Pb}$ evolution curve of Stacey and Kramers (1975) for uranogenic $\mathrm{Pb}$; the values straddle the model curve for thorogenic $\mathrm{Pb}$ in most cases, although a few of the samples plot above the curve. Isotopic compositions are thus significantly less radiogenic than present-day $\mathrm{Pb}$, indicating a time-integrated evolution in a reservoir with relatively low $\mathrm{U} / \mathrm{Pb}$ and $\mathrm{Th} / \mathrm{Pb}$ values.

The Bandelier-Toledo-Valles magmatic system fluctuates in isotopic composition from relatively unradiogenic in Otowi (and the early units from the Cerro Toledo Rhyolite) to slightly more radiogenic in younger units of the Cerro Toledo Rhyolite, Tshirege Member, and early Valles Rhyolite domes (fig. 3). The younger Valles domes are significantly less radiogenic than the Tshirege Member and older Valles domes. The overall zigzag pattern from less to more radiogenic and back again to less radiogenic compositions seems to be an important feature that characterizes the entire magmatic system from pre-Bandelier rhyolites to the most recent Valles rhyolites. 


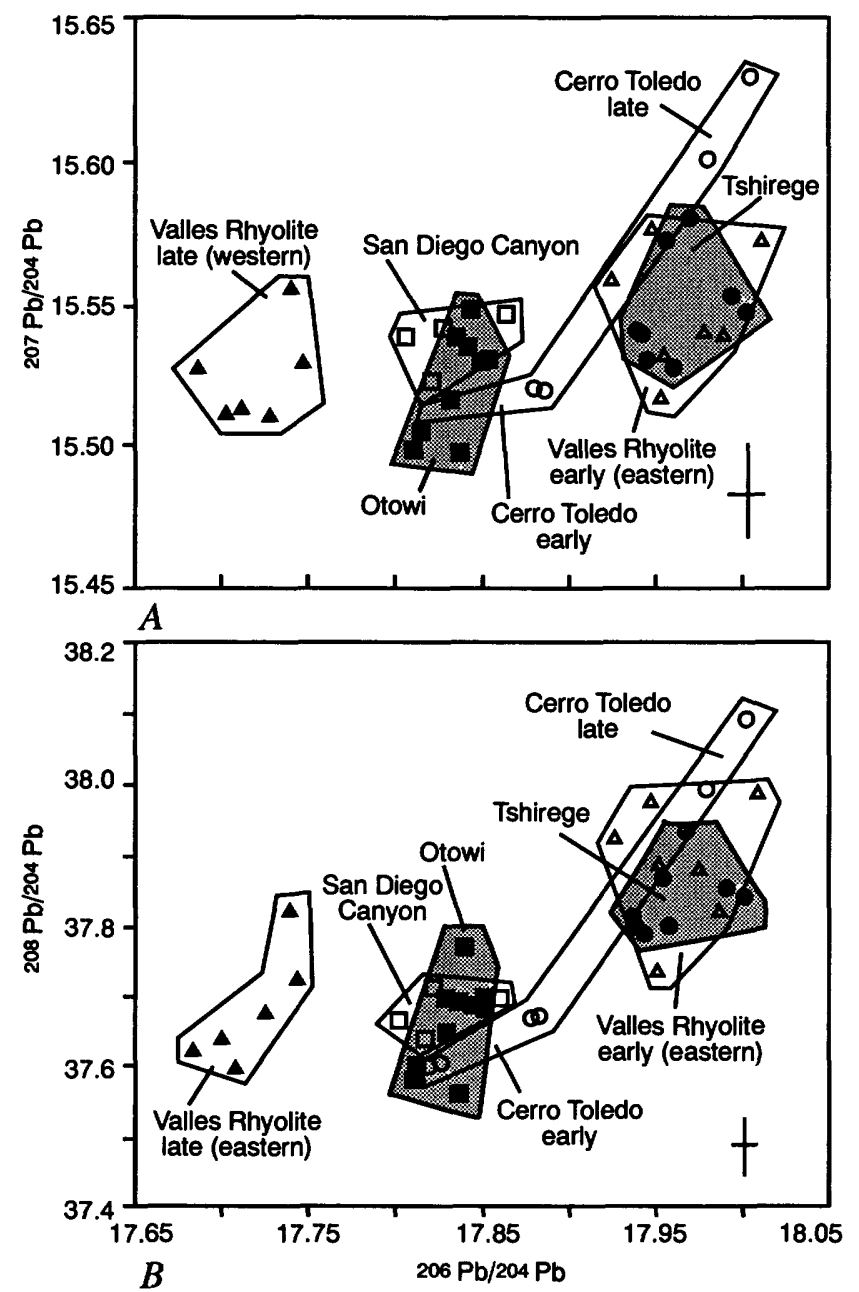

Figure 3. Range of $\mathrm{Pb}$ isotope compositions in the Bandelier Tuff magma system. $A,{ }^{206} \mathrm{~Pb} / 204 \mathrm{~Pb}$ vs. ${ }^{207} \mathrm{~Pb} /{ }^{204} \mathrm{~Pb} . B,{ }^{206} \mathrm{~Pb} / 204 \mathrm{~Pb}$ vs. ${ }^{208} \mathrm{~Pb} /{ }^{204} \mathrm{~Pb}$. Analytical uncertainty at 2 sigma is shown by crosses in lower right portion of each part of figure.

A small but significant $\mathrm{Pb}$ isotopic difference distinguishes the two major members of the Bandelier Tuff (Ayuso and Smith, 1989) - The Otowi Member is less radiogenic than the Tshirege Member (fig. 3). More importantly, each member plots as a coherent isotopic group. $\mathrm{Pb}$ isotope compositions of sanidines are indistinguishable from the whole-rock compositions, indicating that phenocrysts and matrix were in isotopic equilibrium.

Early and late ash flows within individual members of the Bandelier Tuff do not have significant differences in their $\mathrm{Pb}$ isotope compositions (table 1); in contrast, there is a strong zonation in abundances of the trace elements (Smith, 1979). For example, early Otowi ash flows are higher in Ta $(16 \mathrm{ppm})$ and lower in $\mathrm{Eu}(0.03 \mathrm{ppm})$ relative to late ash flows, which are lower in $\mathrm{Ta}(4.2 \mathrm{ppm})$ and higher in $\mathrm{Eu}$ (0.097 ppm); the $\mathrm{Pb}$ isotope compositions, however, are virtually the same between the early ash flows $\left({ }^{206} \mathrm{~Pb} /{ }^{204} \mathrm{~Pb}=\right.$ 17.816) and the late ash flows $\left({ }^{206} \mathrm{~Pb} /{ }^{204} \mathrm{~Pb}=17.853\right)$.
Similarly, no isotopic gradients are evident in the Tshirege Member because the total variation in ${ }^{206} \mathrm{~Pb} /{ }^{204} \mathrm{~Pb}$ is from 17.957 to 18.003; again, this is in contrast to an obvious zonation in $\mathrm{Ta}$, from 12.5 to $3 \mathrm{ppm}$, and in $\mathrm{Eu}$, from 0.1 to $0.9 \mathrm{ppm}$, between early and late ash flows.

$\mathrm{Pb}$ isotope compositions of the Cerro Toledo Rhyolite overlap the Otowi and Tshirege Members of the Bandelier Tuff (Ayuso and Smith, 1989) (table 1). Stratigraphically lower samples of Cerro Toledo Rhyolite match the isotopic composition of the Otowi Member; up section, the Cerro Toledo Rhyolite is more radiogenic resembling the values in the Tshirege Member (fig. 3). The overall $\mathrm{Pb}$ isotope evolution of the Cerro Toledo Rhyolite thus provides direct evidence for recharge of the Bandelier Tuff magma chamber prior to eruption of the Tshirege Member, consistent with suggestions made on the basis of major- and trace-element variations (Smith, 1979; Stix and others, 1988).

The Valles Rhyolite domes have a wide range of $\mathrm{Pb}$ isotope compositions (table 1; fig. 3) that can be grouped according to age and generally according to location of individual domes. Redondo Creek Rhyolite and rhyolites from the older Valles domes (Cerros del Medio, Abrigo, Santa Rosa, and Seco) overlap the relatively radiogenic compositions and trace-element contents of the Tshirege Member of the Bandelier Tuff. In contrast, the $\mathrm{Pb}$ isotopic compositions of the younger Valles domes and flows (San Antonio, South Mountain, Battleship Rock, and Banco Bonito) are even less radiogenic than the Otowi Member of the Bandelier Tuff (fig. 3).

\section{PRE-BANDELIER VOLCANIC ROCKS}

Quaternary basalts that underlie the Bandelier Tuff at Totavi and at El Alto (table 1) and intra-Bandelier basaltic andesites in the Rio Grande gorge (Doe and others, 1969) overlap the $\mathrm{Pb}$ isotopic values of the Bandelier Tuff (figs. $2 B, 2 C$ ). The $\mathrm{Pb}$ isotopic composition from Tertiary basalt (Doe and others, 1969) and from Tertiary andesites from the Tschicoma Formation and Paliza Canyon Formation (Keres Group) overlap the Bandelier Tuff (fig. 2).

The pre-Bandelier rhyolite ash flows that chronologically and spatially(?) represent the closest precursor to the Bandelier Tuff (erupted about $0.3 \mathrm{~m}$.y. prior to the Otowi eruption and collapse of the Toledo caldera) match the isotopic compositions of the Otowi Member (table 1; fig. 3). The pre-Bandelier ash flows may represent early leaks from the Bandelier Tuff magma chamber (Smith, 1979; Turbeville and Self, 1988). Other pre-Bandelier rhyolites and rhyodacites have $\mathrm{Pb}$ isotopic values that can be grouped on the basis of their relative location north and south of the Valles caldera. Tertiary and Quaternary rhyolites north of the caldera (El Rechuelos Rhyolite) are less radiogenic than the Bandelier Tuff; the Canovas Canyon Rhyolite south of the Valles caldera is more radiogenic; and the Bearhead 
Rhyolite has ${ }^{206} \mathrm{~Pb} /{ }^{204} \mathrm{~Pb}$ values between those of the Otowi and the Tshirege Members of the Bandelier Tuff.

Tertiary dacites, rhyodacites, and quartz latites from most of the Tschicoma Formation (Polvadera Group) are generally slightly less radiogenic than the Bandelier Tuff (fig. 2). Our $\mathrm{Pb}$ isotopic data for Tschicoma dacitic rocks project generally toward the composition of K-feldspars from Proterozoic granite; thus, they are consistent with an origin by melting of a crustal source and mixing with basalt that had previously assimilated Proterozoic upper crustal rocks. However, the lower ${ }^{207} \mathrm{~Pb} /{ }^{204} \mathrm{~Pb}$ values of Tertiary thyodacite and Quaternary rhyolites (table 1; fig. 2A), and the trend toward compositions less radiogenic than analyzed Proterozoic granites suggest involvement of an old, unradiogenic (low $\mathrm{U} / \mathrm{Pb}$ ) source. In general, the data overlap the unradiogenic portion of the extensive isotopic field for 1.7Ga plutonic rocks from the Taos Range in northern New Mexico (J. Wooden, J. Aleinikoff, and J. Reed, unpub. data, 1989) and trend toward the field of massive sulfide deposits (1.7-1.8 Ga) (Doe and others, 1979).

K-feldspars from Proterozoic granitic rocks southwest of the Valles caldera (e.g., Guadalupe Box, Soda Dam) and from the Sangre de Cristo Mountains have relatively unradiogenic $\mathrm{Pb}$ initial ratios, plotting below the $\mathrm{Pb}$ model curve (table 1; fig. 2). K-feldspars have model ages of up to $1.45 \mathrm{Ga}$ and ${ }^{238} \mathrm{U} /{ }^{204} \mathrm{~Pb}$ of about 9.5-9.9. The range in $\mathrm{Pb}$ isotope compositions overlaps the field for Proterozoic (1.7$\mathrm{Ga}$ ) granitic rocks in northern New Mexico and Colorado (J. Wooden and others, unpub. data). Whole-rock granite values near the Valles caldera are widely variable, however, and span a broad band from about $1.45 \mathrm{Ga}$ toward the present.

\section{DISCUSSION}

Otowi ash flows that have the lowest incompatible element content represent the lowest level erupted from the Bandelier magma chamber; these constitute the dominant volume of magma tapped by the eruption (fig. 4) (Smith, 1979). Such samples best characterize the starting compositions of the Otowi subsystem and correspond generally to subunits IV and V in the Tshirege Member, which likewise represent the lowest level tapped and the most likely starting composition for the Tshirege subsystem. In both cases, however, estimated starting compositions could be related to even more mafic magmas.

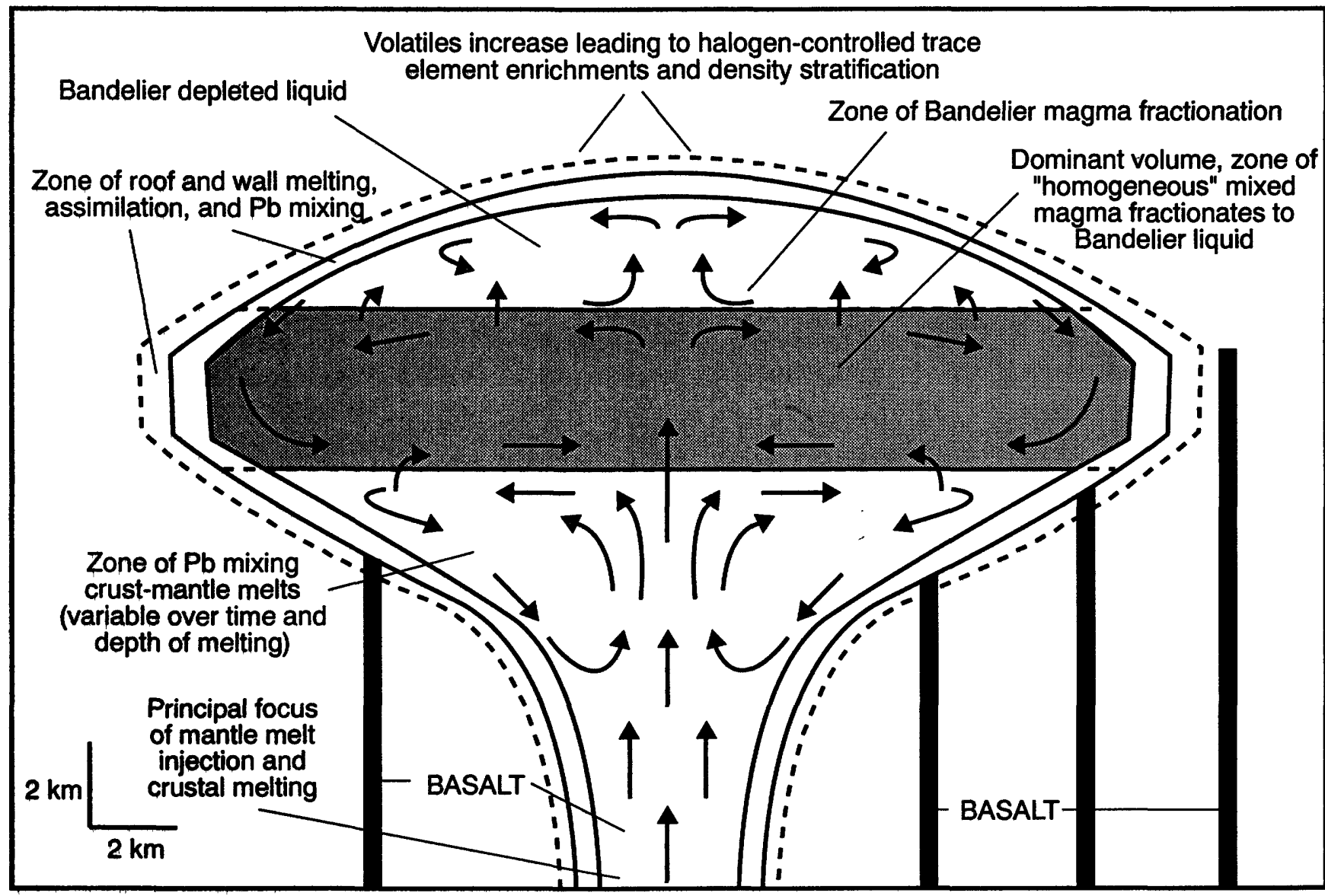

Figure 4. Hypothetical magma chamber model for the Bandelier Tuff. 
If the Bandelier Tuff had been produced exclusively by fusion of the analyzed Proterozoic granites, its values for uranogenic and thorogenic $\mathrm{Pb}$ ideally would be within the granite field (fig. 2). Although there is a substantial overlap, there is no exact isotopic match. Also, ${ }^{208} \mathrm{~Pb} /{ }^{204} \mathrm{~Pb}$ values of the Bandelier Tuff are higher relative to Proterozoic granites; therefore, the total fusion of these rocks cannot produce the entire spectrum of $\mathrm{Pb}$ isotope compositions in the Bandelier Tuff.

The Bandelier Tuff has $\mathrm{Pb}$ isotopic differences that cannot be related to fractional crystallization or melting of a basaltic parent. Differentiation of basalt is incapable of producing isotopic fractionation of radiogenic heavy isotopes within a comagmatic sequence (Leeman and Hawkesworth, 1986) and is incapable of producing the elevated values of incompatible elements found in the Bandelier Tuff. Although we accept the idea that fractionation operated in the Bandelier magma chamber (Warshaw and Smith, 1988), we have concluded that fractionation alone is not a viable mechanism to explain the small but consistent isotopic differences among the different members of the Bandelier Tuff magmatic system. In addition, melting of a mafic source similar to the basalts analyzed in this study is not likely to account for the observed range of isotopic values or for the major- and trace-element variations in the high-silica rhyolites.

Because the uranogenic $\mathrm{Pb}$ isotopic composition of the Bandelier Tuff is intermediate between that of Proterozoic granites near the Valles caldera and Quaternary basalts, we think that the dominant volume of the Bandelier chamber may have been generated by mixing mantle-derived mafic magma and crustally derived sialic magma. In fact, a close association between mantle-derived and rhyolitic magmas has been shown in many studies of ash-flow tuffs (e.g., Doe and others, 1982; Hildreth and others, 1984; Bacon and others, 1984). Totavi basalt or intra-Bandelier basaltic andesites may represent mafic magmas that provided the heat necessary for melting in the mid-crust starting about 2.5 m.y. ago (Smith and Shaw, 1975; Luedke and Smith, 1978) and that probably constituted an intermittent source of material during the evolution of the Bandelier magma system. The basalts near the Valles caldera might have been previously contaminated by old, unradiogenic Proterozoic granitic rocks, consistent with suggestions that apply to adjacent regions (Lipman and others, 1978; Johnson and Lipman, 1988). The felsic magma invoked in this mixing scenario could have been produced from Proterozoic basement.

After eruption of the Otowi Member, a large volume of magma remained that still contained remnants of the less radiogenic upper parts of the Otowi magma chamber, as indicated by the $\mathrm{Pb}$ isotope composition of the early units of the Cerro Toledo Rhyolite, which represent "leaks" of this magma. $\mathrm{Pb}$ isotope zonation in the Cerro Toledo Rhyolite cannot be explained by liquid-state diffusive processes or by fractional crystallization, although the latter process appar- ently explains the trace-element variations (Stix and others, 1988). After eruption of the Otowi Member and before eruption of the Tshirege, there must have been renewed input of magmas with more radiogenic $\mathrm{Pb}$ isotope compositions. Continued fractionation, assimilation of roof rocks (Smith, 1979; Heiken and others, 1986; Stix and others, 1988)-as suggested by xenoliths of older volcanic rocks, Proterozoic granites, and Proterozoic metamorphic rocks-and mixing with new increments of more radiogenic magma ultimately shifted the composition of the Cerro Toledo Rhyolite toward the composition of the Tshirege Member. This shift produced the observed continuum of $\mathrm{Pb}$ isotopic values from the Cerro Toledo Rhyolite to the Tshirege (Ayuso and Smith, 1989) and the progressively higher abundances of incompatible elements in successively younger tephras of the Cerro Toledo Rhyolite (Smith, 1979; Stix and others, 1988; Stix and Gorton, 1990).

The higher and distinct $\mathrm{Pb}$ isotopic values in the Tshirege Member cannot be explained by fractional crystallization of Otowi-like magma. The Tshirege chamber may well have been roofed by consolidated remnants of pre-Bandelier plutons or by partly consolidated Otowi magma. Alternatively, the Otowi Member and the Tshirege Member of the Bandelier Tuff could represent separate evolutionary events, but this does not account for the intermediate $\mathrm{Pb}$ isotopic compositions of the Cerro Toledo Rhyolite.

Isotopic variations in the Valles Rhyolite domes appear to be influenced by their location and age. Following collapse of the Valles caldera, fresh inputs of magma produced (1) early rhyolitic leaks (Redondo Creek Member) on the western side of the Valles caldera and (2) relatively radiogenic compositions in Valle Grande Member domes (Cerro Medio, Abrigo, Santa Rosa, San Luis, Seco) on the eastern and northern side of the caldera that match the isotopic composition of Tshirege Member. This isotopic resemblance suggests that Tshirege magma was not completely drained and that it continued to evolve toward a chemically more fractionated and less radiogenic composition, perhaps by wallrock assimilation and (or) mixing with new unradiogenic magma. In order to explain the geochemical trend, Smith (1979) suggested that, after eruption of this early postcaldera magma, there was a thermal hiatus and a change from convective to conductive cooling. If the chamber solidified at this time, the later magmatic activity that produced the youngest and least radiogenic Valles Rhyolite domes and flows (San Antonio I and II, South Mountain, Battleship Rock, and Banco Bonito) in the western half of the caldera must represent a separate event, possibly involving melting and mixing of larger increments of unradiogenic magma from depth.

$\mathrm{Pb}$ isotopic signatures of younger domes in the Valle Grande Member (San Antonio I and II) are less radiogenic than those of older domes and form two distinct $\mathrm{Pb}$ isotopic groups (Ayuso and Smith, 1989) that also have distinct initial $\mathrm{Sr}$ isotopic ratios (Spell and others, 1989). In fact, the $\mathrm{Pb}$ 
isotopic data establish a genetic link between the youngest domes of the Valle Grande Member (San Antonio I and II) and the youngest Valles Rhyolite units (Battleship Rock and Banco Bonito members). Molybdenum mineralization and intense alteration effects are concentrated in tuffs of the Valles Rhyolite, for the most part, and in the upper part of the Tshirege Member of the Bandelier Tuff. This type of mineralization conceivably could represent a shallow expression of a deeper, Climax- or granite-type (White and others, 1981) stockwork molybdenite mineralization (Hulen and others, 1987). The $\mathrm{Pb}$ isotope composition of the mineral assemblage associated with the molybdenum mineralization is unknown, but that of the host Valles Rhyolite, as indicated above, spans a wide spectrum. If the mineralization were related specifically to the Battleship Rock Member of the Valles Rhyolite (J. Hulen, oral commun., 1993), the mineralized rocks would resemble the least radiogenic units in the magmatic system. In the Creede district Colorado, a classic example of a mineralized fossil hydrothermal system that shares many geological attributes with the Valles caldera, $\mathrm{Pb}$ isotope compositions evolved toward more radiogenic values as a function of age of the mineralized rocks. For example, the older hydrothermal assemblages in the Creede district associated with gold mineralization contain the least radiogenic $\mathrm{Pb}$; in contrast, the younger assemblages associated with silver and base metals are the most radiogenic (Foley and Ayuso, in press).

The evolving Bandelier Tuff magmatic system thus grew by incremental replenishment with mantle-derived mafic magma into the bottom of the chamber, by mixing with silicic crustal melts, and by assimilation of relatively unradiogenic silicic wallrocks near the top of the chamber (fig. 4) (Smith, 1979). The magmatic system was open (e.g., Smith, 1979; Lipman, 1984, 1988; Hildreth and others, 1984) and dynamic in the sense that several isotopically distinct magma batches were added to the Bandelier magmatic system during its evolution. Despite the isotopic differences between the Otowi Member and the Tshirege Member, it seems clear that major members of the Bandelier Tuff are linked in a chemical continuum by tephras from the Cerro Toledo Rhyolite, which represent recharging and continued fractionation of the system. This interpretation is in agreement with the long-lived nature of the magmatic system associated with the Valles and Toledo calderas (Smith and Bailey, 1966, 1968; Self and others, 1986; Heiken and others, 1986).

Some other pre-Bandelier rocks may also have been part of the Bandelier system, although their isotopic heterogeneity clearly identifies them as "separate" magma batches. Isotopic changes from less radiogenic $\mathrm{Pb}$ to more radiogenic $\mathrm{Pb}$ and back again to less radiogenic compositions after caldera-forming eruptions are an important feature of the Bandelier magmatic system. In such periodically discharged volcanic systems, magmas whose isotopic signatures differ greatly from magmas deeper in the chamber may be entirely or partially removed (Smith and Macdonald, 1979; Lipman, 1984; Druitt and Bacon, 1988; Ayuso and Smith, 1989). When the magma chamber ultimately solidifies to plutonic rock, crystallization after complete removal of the upper volcanic members or convective homogenization may obliterate the initial isotopic heterogeneity in the magmatic system. However, where the upper volcanic members are not eroded entirely, or if homogenization does not occur, the initial isotopic zonation may be preserved.

\section{ACKNOWLEDGMENTS}

We thank R.A. Bailey, B.R. Doe, N.K. Foley, M.F. Horan, and R.P. Koeppen for their many helpful suggestions, comments, and reviews of the paper.

\section{REFERENCES CITED}

Ayuso, R.A., Horan, M.F., and Criss, R.E., 1988, $\mathrm{Pb}$ and $\mathrm{O}$ isotopic geochemistry of granitic plutons in northern Maine: American Journal of Science, v. 288A, p. 421-460.

Ayuso, R.A., and Smith, R.L., 1989, Lead isotopic diversity in the Bandelier Tuff, Valles caldera, and related rocks of the Jemez Mountains, New Mexico [abs.]: International Association of Volcanology and Chemistry of the Earth's Interior, Santa Fe, New Mexico Bureau of Mines and Mineral Resources, Bulletin 131, p. 10.

Bacon, C.R., Kurazawa, H., Delevaux, M., Kistler, R.W., and Doe, B.R., 1984, Lead and strontium isotopic evidence for crustal interaction and compositional zonation in the source regions of Pleistocene basaltic and rhyolitic magmas of the Coso volcanic field, California: Contributions to Mineralogy and Petrology, v. 85 , p. $366-375$.

Bailey, R.A., Smith, R.L., and Ross, C.S., 1969, Stratigraphic nomenclature of volcanic rocks in the Jemez Mountains, New Mexico: U.S. Geological Survey Bulletin 1274-P, p. 1-19.

Doe, B.R., Leeman, W.P., Christiansen, R.L., and Hedge, C.E., 1982 , Lead and strontium isotopes and related trace elements as genetic tracers in the upper Cenozoic rhyolite basalt association of the Yellowstone plateau volcanic field: Journal of Geophysical Research, v. 87, p. 4786-4806.

Doe, B.R., Lipman, P.W., Hedge, C.E., and Kurazawa, H., 1969, Primitive and contaminated basalts from the southern Rocky Mountains: Contributions to Mineralogy and Petrology, v. 21, p. 142-156.

Doe, B.R., Steven, T.A., Delevaux, M.H., Stacey, J.S., Lipman, P.W., and Fisher, F.S., 1979, Genesis of ore deposits in the San Juan volcanic field, southwestern Colorado-Lead isotope evidence: Economic Geology, v. 74, p. 1-26.

Doell, R.R., Dalrymple, G., Smith, R.L., and Bailey, R.A., 1968, Paleomagnetism, potassium-argon ages, and geology of rhyolites and associated rocks of the Valles caldera, New Mexico: Geological Society of America Memoir 116, p. 211-248.

Druitt, T.H., and Bacon, C.R., 1988, Petrology of the zoned calcalkaline magma chamber of Mount Mazama, Crater Lake, 
Oregon: Contributions to Mineralogy and Petrology, v. 101, p. 245-259.

Foley, N.K., and Ayuso, R.A., in press, Paragenetic constraints on $\mathrm{Pb}$ isotopic evolution of the north amethysts $\mathrm{Au}-\mathrm{Ag}$ vein system, Creede mining district, San Juan volcanic field: Economic Geology.

Gardner, J.N., Goff, F., Garcia, S., and Hagan, R.C., 1986, Stratigraphic relations and lithologic variations in the Jemez volcanic field, New Mexico: Journal of Geophysical Research, v. 91, p. 1763-1778.

Goff, F., and Gardner, J.N., 1988, Valles caldera region, New Mexico, and the emerging continental scientific drilling program: Journal of Geophysical Research, v. 93, p. 5997-5999.

Halliday, A.N., Fallick, A.E., Hutchinson, J., and Hildreth, W., 1984, A Nd, Sr and O isotopic investigation into the causes of chemical and isotopic zonation in the Bishop Tuff, California: Earth and Planetary Science Letters, v. 68, p. 379-391.

Halliday, A.N., Mahood, G.A., Holden, P., Metz, J.M., Dempster, T.J., and Davidson, J.P., 1989, Evidence for long residence times of rhyolitic magma in the Long Valley magmatic system-The isotopic record in precaldera lavas of Glass Mountain: Earth and Planetary Sciences Letters, v. 94, p. 274-290.

Heiken, G., Goff, F., Stix, J., Tamanyu, S., Shafiqullah, M., Garcia, S., and Hagan, R., 1986, Intracaldera volcanic activity, Toledo caldera and embayment, Jemez Mountains, New Mexico: Journal of Geophysical Research, v. 91, p. 1799-1815.

Hervig, R.L., and Dunbar, N.W., 1992, Cause of chemical zoning in the Bishop (California) and Bandelier (New Mexico) magma chambers: Earth and Planetary Science Letters, v. 111, p. 97-108.

Hildreth, W., 1979, The Bishop Tuff-Evidence for the origin of compositional zonation in silicic magma chambers: Geological Society of America Special Paper 180, p. 43-75.

Hildreth, W., Christiansen R.L., and O'Neil, J.R., 1984, Catastrophic isotopic modification of rhyolitic magma at times of caldera subsidence, Yellowstone plateau volcanic field: Journal of Geophysical Research, v. 89, p. 8339-8370.

Hulen, J.B., Nielson, D.L., Goff, F., Gardner, J.N., and Charles, R.W., 1987, Molybdenum mineralization in an active geothermal system, Valles caldera, New Mexico: Geology, v. 15, p. 748-752.

Izett, G.J., Obradovich, J., Naeser, C., Cebula, G., 1981, Potassiumargon and fission-track zircon ages of Cerro Toledo rhyolite and tephra units in the Jemez Mountains, New Mexico: U.S. Geological Survey Professional Paper 1199-D, p. 37-43.

Johnson, C.M., 1989, Isotopic zonations in silicic magma chambers: Geology, v. 17, p. 1136-1139.

Johnson, C.M., and Lipman, P.W., 1988, Origin of metaluminous and alkaline volcanic rocks of the Latir volcanic field, northern Rio Grande rift, New Mexico: Contributions to Mineralogy and Petrology, v. 100, p. 107-128.

Johnson, C.M., Lipman, P.W., and Czamanske, G.K., 1990, H, O, $\mathrm{Sr}, \mathrm{Nd}$, and $\mathrm{Pb}$ isotope geochemistry of the Latir volcanic field and cogenetic intrusions, New Mexico, and relations between evolution of a continental magmatic center and modifications of the lithosphere: Contributions to Mineralogy and Petrology, v. 104 , p. 99-124.

Leeman, W.P., and Hawkesworth, C.J., 1986, Open magma systems-Trace element and isotopic constraints: Journal of Geophysical Research, v. 91, p. 5901-5912.
Lipman, P.W., 1984, The roots of ash flow calderas in Western North America-Windows into the tops of granitic batholiths: Journal of Geophysical Research, v. 89, p. 8801-8841.

1988, Evolution of silicic magma in the upper crust-The mid-Tertiary Latir volcanic field and its cogenetic granitic batholith, northern New Mexico, U.S.A.: Transactions of the Royal Society of Edinburgh, Earth Sciences, v. 79. p. 265-288.

Lipman, P.W., Doe, B.R., Hedge, C.E., and Steve, T.A., 1978, Petrologic evolution of the San Juan volcanic field, southwestern Colorado- $\mathrm{Pb}$ and $\mathrm{Sr}$ isotopic evidence: Bulletin of the Geological Society of America, v. 89, p. 59-82.

Lipman, P.W., and Friedman, I., 1975, Interaction of meteoric water with magma-An oxygen isotope study of ash-flow sheets from southern Nevada: Geological Society of America Bulletin, v. 86, p. 695-702.

Loeffler, B.M., Vaniman, D.T., Baldridge, W.S. and Shafiqullah, M., 1988, Neogene rhyolites of the Northern Jemez volcanic field, New Mexico: Journal of Geophysical Research, v. 93, p. 6157-6167.

Ludwig, K., 1988, A plotting and regression program for radiogenic isotope data: U.S. Geological Survey Open-File Report 88-557, $41 \mathrm{p}$.

Luedke, R.G, and Smith, R.L., 1978, Map showing distribution, composition, and age of Late Cenozoic volcanic centers in Arizona and New Mexico: U.S. Geological Survey Miscellaneous Investigations Series Map I-1091-A, scale 1:1,000,000.

Macdonald, R., and Smith, R.L., 1988, Relationships between silicic plutonism and volcanism: Geochemical evidence: Transactions of the Royal Society of Edinburgh, Earth Sciences, v. 79, p. 257-263.

Noble, D.C., and Hedge, C.E., $1969,{ }^{87} \mathrm{Sr} /{ }^{86} \mathrm{Sr}$ variations within individual ash-flow sheets: U.S. Geological Survey Professional Paper 650-C, p. 133-139.

Self, S., Goff, F., Gardner, J.N., Wright, J.V., and Kite, W.M., 1986, Explosive rhyolitic volcanism in the Jemez Mountains-Vent locations, caldera development and relation to regional structure: Journal of Geophysical Research, v. 91, p. 1779-1798.

Self, S., Kircher, D.E., and Wolff, J.A., 1988, The El Cajete series, Valles caldera, New Mexico: Journal of Geophysical Research, v. 93, p. 6113-6127.

Skuba, C.E., and Wolff, J.A., 1989, Trace element and radiogenic isotope constraints on the genesis and evolution of rhyolitic magmas beneath Valles caldera [abs.]: International Association of Volcanology and Chemistry of the Earth's Interior, Santa Fe, New Mexico Bureau of Mines and Mineral Resources, Bulletin 131, p. 245.

Smith, R.L., 1979, Ash-flow magmatism, in Chapin, C.E., and Elston, W.E., eds., Ash-Flow Tuffs: Geological Society of America Special Paper 180, p. 5-27.

Smith, R.L., and Bailey, R.A., 1966, The Bandelier Tuff-A study of ash-flow eruption cycles from zoned magma chambers: Bulletin of Volcanology, v. 29, p. 83-104.

1968, Resurgent cauldrons: Geological Society of America, Memoir 116, p. 613-662.

Smith, R.L., Bailey, R.A., and Ross, C.S., 1970, Geologic map of the Jemez Mountains, New Mexico: U.S. Geological Survey Miscellaneous Investigations Series Map I-571, scale $1: 125,000$. 
Smith, R.L., and Macdonald, R., 1979, Rhyolitic volcanism and its relation to granitic plutonism [abs]: Geological Society of America Abstracts with Programs, v. 11, p. 520.

Smith, R.L., and Shaw, H.R., 1975, Igneous-related geothermal phenomena: U.S. Geological Survey Circular 726, p. 58-83.

Spell, T.L., and Kyle, P.R., 1989, Petrogenesis of Valle Grande Member rhyolites, Valle caldera, New Mexico-Implications for evolution of the Jemez Mountain magmatic system: Journal of Geophysical Research, v. 94, p. 10379-10396.

Spell, T.L., Kyle, P.R., and Thirlwell, M., 1989, Geochemistry and $\mathrm{Sr}$ isotopic compositions of post-Bandelier Tuff rhyolites, Valles caldera, New Mexico-Evidence for multiple magma systems in the Jemez Mountains volcanic field [abs.]: International Association of Volcanology and Chemistry of the Earth's Interior, Santa Fe, New Mexico Bureau of Mines and Mineral Resources, Bulletin 131, p. 251.

Stacey, J.D., and Kramers, J.N., 1975, Approximation of terrestrial lead isotope evolution by a two-stage model: Earth and Planetary Science Letters, v. 36, p. 207-222.

Stix, J., Goff, F., Gorton, M.P., Heiden, G., and Garcia, S.R., 1988, Restoration of compositional zonation in the Bandelier silicic magma chamber between two caldera-forming eruptionsGeochemistry and origin of the Cerro Toledo Rhyolite, Jemez
Mountains, New Mexico: Journal of Geophysical Research, v. 93, p. 6129-6147.

Stix, J., and Gorton, M.P., 1990, Variations in trace element partition coefficients in sanidine in the Cerro Toledo Rhyolite, Jemez Mountains, New Mexico-Effects of composition, temperature and volatiles: Geochimica et Cosmochimica Acta, v. 54, no. 10, p. 2697-2708.

Tegtmeyer, K., and Farmer, G.L., 1989, Isotopic evidence for the origin of late Tertiary metaluminous and peralkaline rhyolites from the Great Basin, Western U.S.: International Association of Volcanology and Chemistry of the Earth's Interior, Santa $\mathrm{Fe}$, New Mexico Bureau of Mines and Mineral Resources, Bulletin 131, p. 266.

Turbeville, B.N., and Self, S., 1988, San Diego Canyon ignimbrites-Pre-Bandelier tuff explosive rhyolitic volcanism in the Jemez Mountains, New Mexico: Journal of Geophysical Research, v. 93, p. 6148-6156.

Warshaw, C.M., and Smith, R.L., 1988, Pyroxenes and fayalites in the Bandelier Tuff, New Mexico-Temperatures and comparison with other rhyolites: American Mineralogist, v. 73, p. 1025-1037.

White, W.H., Bookstrom, A.A., Kamilli, R.J., Ganster, M.W., Smith, R.P., Ranta, D.R., and Steininger, R.C., 1981, Character and origin of Climax-type molybdenum deposits: Economic Geology, 75th Anniversary Volume, p. 270-316. 


\title{
CHAPTER B
}

\section{IMPLICATIONS OF EOCENE THROUGH MIOCENE AGES FOR VOLCANIC ROCKS, SNOWSTORM MOUNTAINS AND VICINITY, NORTHERN NEVADA}

\author{
By Alan R. Wallace ${ }^{1}$ and E.H. McKee ${ }^{2}$
}

\begin{abstract}
New potassium-argon dates on volcanic rocks from the Snowstorm Mountains area in northern Nevada, coupled with existing geochronology and new field mapping, shed new light on three major volcanologic topics in that area. First, new dates show that the hiatus between the eruption of two major middle Miocene bimodal suites was less than 1 million years. Second, a new date on a welded tuff confirms field evidence for a previously unrecognized late Eocene volcanic field west of the Snowstorm Mountains. Third, field relations and additional dates on pre-middle Miocene volcanic rocks define a complex eruption history and distribution of late Eocene and younger volcanic rocks.
\end{abstract}

\section{INTRODUCTION}

The Snowstorm Mountains of western Elko and eastern Humboldt Counties in northern Nevada are underlain by a complex middle Miocene volcanic field erupted onto Paleozoic sedimentary rocks and Eocene, Oligocene, and lower Miocene volcanic rocks (Wallace, 1993; A.R. Wallace, unpub. mapping, 1987-89). Geochronologic studies of the middle Miocene field showed that the volcanics were erupted between about 15 and $6 \mathrm{Ma}$ (Wallace and others, 1990), but the wide range in ages of the volcanic rocks beneath these middle Miocene units was previously unknown.

The new K-Ar dates reported in table 1 are used to evaluate three topics related to Tertiary volcanism and tectonism in north-central Nevada: (1) confirmation and refinement of

\footnotetext{
${ }^{1}$ U.S. Geological Survey, Mail Stop 905, P.O. Box 25046, Denver Federal Center, Denver, CO 80225.

${ }^{2}$ U.S. Geological Survey, Mail Stop 901, 345 Middlefield Road, Menlo Park, CA 94025.
}

the age of early bimodal volcanism in the middle Miocene volcanic field, (2) identification of a previously unrecognized middle Tertiary volcanic field west of the Snowstorm Mountains, and (3) analysis of pre-middle Miocene Tertiary volcanism and tectonism. The purpose of this paper is to elaborate on these topics and make suggestions for additional studies.

\section{MIDDLE MIOCENE VOLCANISM}

Geologic mapping (Wallace, 1990, 1993) in the Snowstorm Mountains has defined two middle Miocene bimodal volcanic sequences. The older sequence consists of predominantly mafic flows and volcaniclastic sedimentary rocks with subordinate amounts of pyroclastic rhyolite tuffs and rhyolitic domes; these units were erupted and emplaced, respectively, between about 16.7 and $14.5 \mathrm{Ma}$ (Wallace and others, 1990; Stewart and others, 1975; Zoback and others, 1994). The younger sequence, composed of anhydrous thyolites and rhyodacites with minor basalt, formed between about 14.3 and $9.8 \mathrm{Ma}_{\text {, }}$ with minor basaltic volcanism at 6.4 Ma (Wallace and others, 1990). The older bimodal assemblage is related to the north-northwest-trending northern Nevada rift, which formed during incipient basin-and-range extension (Zoback and Thompson, 1978; Stewart and others, 1975). The younger bimodal assemblage mostly is a product of early volcanism interpreted to be related to the Yellowstone hot spot (Bonnichsen and Kauffman, 1987; Honjo and Leeman, 1987).

In the Midas mining district in the southeastern part of the Snowstorm Mountains, basaltic andesite forms two sequences that are locally separated by a variably thick pyroclastic unit and lacustrine sedimentary rocks. A dike that fed flows in the lower sequence was dated at $15.1 \pm 0.5 \mathrm{Ma}$ (sample 9LH24; see comment in Appendix regarding possible 
Table 1. Summary of dates for volcanic rocks units, Snowstorm Mountains and vicinity, northern Nevada.

[rad, radiogenic]

\begin{tabular}{llcccc}
\hline Sample no. & Rock type & $\begin{array}{c}\mathrm{K}_{2} \mathrm{O} \\
\text { (weight percent) }\end{array}$ & $\begin{array}{c}{ }^{40} \mathrm{Ar}_{\text {rad }} \\
(\mathrm{mol} / \mathrm{g})\end{array}$ & $\begin{array}{c}{ }^{40} \mathrm{Ar}_{\text {rad }}{ }^{40} \mathrm{Ar}_{\text {total }} \\
\text { (percent) }\end{array}$ & $\begin{array}{c}\text { Age } \\
\text { (Ma) }\end{array}$ \\
\hline 9LH25 & Basaltic andesite & 0.575 & $1.21855 \times 10^{-11}$ & 33.6 & $14.7 \pm 0.5$ \\
9LH24 & Basaltic andesite & 6.43 & $1.401607 \times 10^{-10}$ & 84.4 & $15.1 \pm 0.5$ \\
& Basaltic andesite & 6.43 & $1.399958 \times 10^{-10}$ & 85.4 & $15.1 \pm 0.5$ \\
9LH11 & Andesite & 2.97 & $9.53078 \times 10^{-11}$ & 42.8 & $22.1 \pm 0.7$ \\
9LH22 & Andesite & 0.492 & $2.52043 \times 10^{-11}$ & 39.2 & $35.2 \pm 1.1$ \\
9LH8 & Dacite & 0.928 & $5.1823 \times 10^{-11}$ & 19.8 & $38.4 \pm 1.6$ \\
\hline
\end{tabular}

alteration), and a flow in the upper sequence was dated at $14.7 \pm 0.5 \mathrm{Ma}$ (sample 9LH25). These dates are consistent with other dates reported along the northern Nevada rift (Stewart and others, 1975; Zoback and others, 1994) and with a date of $15.2 \pm 1.6 \mathrm{Ma}$ on a basaltic andesite lava flow west of Midas (Wallace and others, 1990). The mafic volcanic rocks and associated pyroclastic and sedimentary rocks in the Midas district were classified as middle Tertiary by Coats (1987), an age that is too old in light of these new dates.

In Midas, the 14.7-Ma upper basaltic andesite flow underlies by only a few tens of meters the oldest rhyolite unit of the younger bimodal sequence; to the west of Midas, this rhyolitic unit is cut by a rhyolite dike that has been dated at

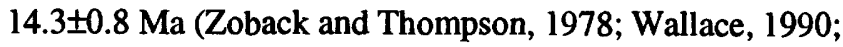
Wallace and others, 1990). Throughout the Snowstorm Mountains, the basaltic andesites that directly underlie the younger rhyolite show no evidence of paleosol development or lag deposits related to surficial processes, despite evidence (paper birch leaves and conifer plant debris in the intervening lacustrine sedimentary rocks; Wallace, 1993) of temperate, nonarid climatic conditions. Combined with the geochronologic data, this evidence indicates relatively little time between the cessation of older bimodal volcanism and inception of younger volcanic activity.

\section{POSSIBLE EOCENE VOLCANIC FIELD}

Along the west to northwest margin of the Snowstorm Mountains, biotite-hornblende rhyolitic to dacitic flows and welded tuffs underlie middle Miocene volcanic and sedimentary rocks (Wallace, 1993; A.R. Wallace, unpub. mapping, 1988-91). A late Eocene date of $38.4 \pm 1.6 \mathrm{Ma}$ (sample 9LH8) was obtained from a dacitic welded tuff in this sequence.

The presence of hydrous mafic minerals petrographically distinguishes the Eocene rocks from the middle Miocene felsic volcanics of the Snowstorm Mountains. The middle Tertiary felsic volcanic rocks elsewhere in northern Nevada typically contain a biotite-hornblende assemblage of mafic minerals (Coats, 1987). In contrast, the middle Miocene volcanic rocks are anhydrous, and the mafic minerals include pyroxenes and olivine (Wallace, 1993). This anhydrous mineralogy typifies felsic volcanic rocks of this age throughout a large area that includes northern Nevada, southeastern Oregon, and southwestern Idaho (Ekren and others, 1984; Rytuba and McKee, 1984), and it probably is the product of partial melting of a granulitic lower crust (Honjo and Leeman, 1987).

Reconnaissance mapping (A.R. Wallace, unpub. mapping, 1988-91) indicates that the biotite-hormblende-bearing volcanic rocks are exposed over a widespread area of at least several tens of square kilometers, generally west and northwest of Chimney Reservoir (fig. 1). The total areal extent of this volcanic field is undoubtedly larger than is shown in figure 1, but parts of it are covered by younger volcanic and sedimentary rocks, so its total size is not known. Volcanic rocks in this area were designated as Miocene (Stewart and Carlson, 1978) and Miocene or Pliocene in age (Willden, 1964). At the spillway for Chimney Reservoir, a biotite rhyodacite forms a north-northwest-trending elongate ridge with a contorted basal vitrophyre and breccia. Thin sections show no evidence of fiamme or phenocryst breakage, indicating that the rock is not a welded tuff. The ridge most likely is an elongate, exogenous dome. To the west, other biotitebearing volcanic rocks are pumiceous welded tuffs with broken phenocrysts.

The nearest documented middle Tertiary felsic volcanic rocks are exposed approximately $60 \mathrm{~km}$ east-southeast of Chimney Reservoir in the vicinity of Willow Creek Reservoir (Stewart and Carlson, 1978; Coats, 1987). These rocks include thick ash-flow tuffs, air-fall tuffs, and tuffaceous sedimentary rocks; the ash-flow tuffs have been dated at 32.9 $\pm 1.1 \mathrm{Ma}$ (recalculated from McKee and others, 1976). Combined with the late Eocene date on the dacite west of the Snowstorm Mountains, field relations and petrography indicate the presence of a late Eocene igneous center in the general vicinity of Chimney Reservoir. Additional field, petrologic, and geochronologic studies are necessary to better define the volcanic rocks and the age of volcanic activity in this area west and northwest of the Snowstorm Mountains. 


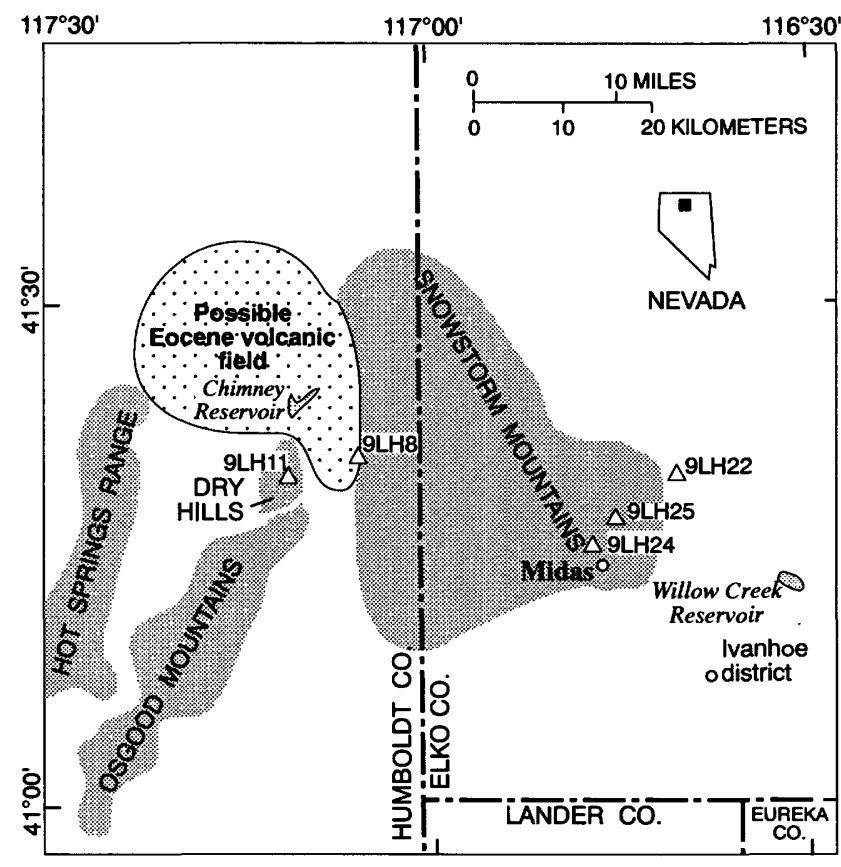

Figure 1. Map showing locations of dated samples (triangles), as well as pertinent geographic features. Location of late Eocene volcanic field (stippled) is conjectural but is shown to provide general location of rocks that might be part of that field.

\section{PRE-MIDDLE MIOCENE VOLCANISM AND TECTONISM}

In addition to the Eocene date on the dacite described above, new K-Ar dates have been obtained from two other pre-middle Miocene volcanic sequences to the west and east of the Snowstorm Mountains. These dates, coupled with field relations and previous geochronologic studies, provide insight into pre-middle Miocene volcanism and tectonism.

The Dry Hills, at the northeast end of the Osgood Mountains, approximately $10 \mathrm{~km}$ south of Chimney Reservoir and $10 \mathrm{~km}$ west of the Snowstorm Mountains (fig. 1), are underlain by a series of andesite flows that blanket Paleozoic sedimentary rocks (Stewart and Carlson, 1978). A date of 22.1 $\pm 0.7 \mathrm{Ma}$ was obtained from an andesite flow in the central part of the Dry Hills (sample 9LH11). Similar andesitic flows are exposed in two large areas along the western and southern flanks of the Osgood Mountains (Hotz and Willden, 1964); andesites in the southern area of outcrop were dated at $22.6 \pm 0.7 \mathrm{Ma}$ (recalculated from Erickson and Marsh, 1974). These three relatively large areas of exposure suggest that the Osgood Mountains-Dry Hills area was covered at least partially by andesitic flows at about $22 \mathrm{Ma}$.

Four major Cenozoic volcanic groups are exposed along the western margin of the Snowstorm Mountains and areas to the northwest and west: the Eocene sequence, the Dry Hills andesites, and the two middle Miocene bimodal assemblages. The distribution of these groups is erratic, due either to nondeposition in certain areas or removal by erosion. In areas where the base of the Dry Hills andesites is exposed, flows clearly were erupted directly onto Paleozoic sedimentary rocks, and the Eocene volcanic rocks are absent. The Eocene volcanic rocks, as exposed at Chimney Reservoir spillway, are capped by lacustrine sedimentary rocks that are related to the younger sequence of middle Miocene volcanism (Wallace, 1993), with no evidence of the intervening Dry Hills andesite or early bimodal-related basalt. Along the western flanks of the Snowstorm Mountains, the Dry Hills-type andesite is not present, and the Paleozoic sedimentary rocks are overlain by Eocene volcanics, basalts of the older bimodal suite, and rhyolites and lacustrine sedimentary rocks of the younger bimodal suite, either individually or in all combinations. Additional work is needed to determine the distributions of these volcanic rocks and their stratigraphic relations west and northwest of the Snowstorm Mountains.

The volcanic stratigraphy on the eastern and southeastern margins of the Snowstorm Mountains is equally complex. Near Scraper Springs, rhyolites of the younger middle Miocene bimodal sequence were emplaced directly on pumice-rich air-fall tuff and tuffaceous sedimentary rocks, which, in turn, overlie andesitic flows and dome-collapse breccias. One of these andesite flows was dated at 35.2 \pm 1.1 Ma (sample 9LH22). The andesites are part of a larger group of late Eocene to early Oligocene andesites that are exposed to the east and northeast of Scraper Springs; they overlie Paleozoic sedimentary rocks $5 \mathrm{~km}$ north of Scraper Springs. The overlying air-fall tuffs and related tuffaceous sedimentary rocks can be traced southeastward some $15 \mathrm{~km}$ to Willow Creek Reservoir, where they directly underlie the 32.9-Ma sequence of welded tuffs.

Twenty kilometers to the south of Scraper Springs, in the Ivanhoe mining district, middle Miocene volcanic rocks, including those of the lower bimodal sequence, directly overlie Paleozoic sedimentary rocks; the early Oligocene tuffaceous sedimentary rocks are absent, and the 32.9-Ma ignimbrites are exposed only locally at the very north end of the district (Bartlett and others, 1990). The extent of premiddle Miocene volcanic rocks west of Scraper Springs is unknown. Volcanic-rock xenoliths of many compositions are present in inter-basaltic andesite pyroclastic rocks in the Midas mining district, but none can be attributed to a specific older unit. No Paleozoic rocks are exposed in the core of the Snowstorm Mountains.

In summary, the volcanic rocks on the margins of the Snowstorm Mountains reveal a complex relationship between volcanism, tectonism, and erosion. The distribution of late Eocene and Oligocene pyroclastic rocks, which would have formed blankets over a subdued paleotopography, is erratic, indicating either substantial post-eruption erosion or rugged paleotopography. Andesitic flows and breccias, such as in the Dry Hills and at Scraper Springs, may have had much greater areal distribution, forming locally thick accumulations. 
The older middle Miocene bimodal volcanism related to the north-northwest-trending northern Nevada rift may have been preceded by thermal doming and attendant erosion. Deep drilling in the Ivanhoe district has revealed a north-northwest-trending paleohorst in the Paleozoic basement upon which middle Miocene volcanic rocks were erupted (Bartlett and others, 1990). Limited evidence suggests that a similar situation may have occurred in the Snowstorm Mountains. In both the Snowstorm Mountains and areas to the south, including the Ivanhoe district, the older bimodal sequence has a limited extent to the east and west. This elongate dome may have foundered during volcanism, permitting the preservation of thousands of meters of Miocene volcanic rocks along its axis.

Although the general volcanic stratigraphy in the Snowstorm Mountains is fairly well understood (Wallace, 1993), additional work clearly is needed to more fully understand relationships in the volcanic rocks to the west and east. This additional work would add to the understanding of middle Tertiary volcanism and tectonism in northern Nevada if coupled with new field and geochronologic studies of middle Tertiary volcanism and related tectonics in eastern Elko County by Thorman and others (1993).

\section{ECONOMIC GEOLOGY}

A belt of bulk-minable gold deposits, known as the Getchell trend, is located along the eastern base of the Osgood Mountains west of the Snowstorm Mountains (fig. 1). The deposits occur in Paleozoic sedimentary rocks and Cretaceous igneous rocks. The age of mineralization is a point of controversy, with one camp arguing for a Cretaceous age (Silberman and others, 1974) and the other for a middle Tertiary or Miocene age (Joraleman, 1975). Andesite flows in the Dry Hills extend to within a few kilometers of the northern exposed limit of the gold belt. Establishing the temporal relationship between the volcanic rocks and the gold deposits would demonstrate that the deposits are either younger or older than $22 \mathrm{Ma}$. If they are older, the area beneath the volcanic rocks would have significant potential for undiscovered, concealed gold deposits; if they are younger, then altered andesites might provide a guide to undiscovered mineral deposits.

Late Eocene volcanic rocks host precious metal deposits in several places east of the Snowstorm Mountains, including the Tuscarora, Burner Hills, and Good Hope districts (LaPointe and others, 1991). Mineralization at these locations was related genetically to the volcanic systems. Although mineralized rocks were not observed in the late Eocene volcanic rocks west of the Snowstorm Mountains, evidence for an eruptive center in that area raises the possibility that mineralization may have accompanied volcanic activity.
The middle Miocene volcanic rocks host epithermal precious metal deposits at Midas and in the Ivanhoe district, and these volcanic rocks contain mineral deposits to the north-northwest and south-southeast. Geologic and geochronologic evidence indicates that the mineral deposits were formed during the waning stages of the older middle Miocene bimodal volcanic activity or the very earliest stages of the younger bimodal volcanism (Wallace, 1993; Bartlett and others, 1990). In the vicinity of the Snowstorm Mountains, middle Miocene volcanic rocks do not extend to the east or west, and related mineral deposits therefore would not be expected beyond the limits of these volcanic rocks.

\section{REFERENCES CITED}

Bartlett, M.W., Enders, M.S., and Hruska, D.C., 1990, Geology of the Hollister gold deposit, Ivanhoe district, Elko County, Nevada, in Raines, G.L., Lisle, R.E., Schafer, R.W., and Wilkinson, W.H., eds., Geology and Ore Deposits of the Great Basin, Symposium Proceedings: Reno, Geological Society of Nevada, p. 957-978.

Bonnichsen, Bill, and Kauffman, D.F., 1987, Physical features of rhyolite lava flows in the Snake River Plain volcanic province, southwestern Idaho: Geological Society of America Special Paper 212, p. 119-145.

Coats, R.R., 1987, Geology of Elko County, Nevada: Nevada Bureau of Mines and Geology Bulletin 101, $112 \mathrm{p}$.

Cox, Allan, and Dalrymple, G.B., 1967, Statistical analysis of geomagnetic reversal data and the precision of potassium-argon dating: Journal of Geophysical Research, v. 72, no. 10, p. 2603-2614.

Dalrymple, G.B., and Lanphere, M.D., 1969, Potassium-Argon Dating: San Francisco, W.H. Freeman and Co., 258 p.

Ekren, E.B., McIntyre, D.H., and Bennett, E.H., 1984, High-temperature, large-volume, lavalike ash-flow tuffs without calderas in southwestern Idaho: U.S. Geological Survey Professional Paper 1272, 76 p.

Erickson, R.L., and Marsh, S.P., 1974, Geologic map of the Golconda quadrangle, Humboldt County, Nevada: U.S. Geological Survey Geologic Quadrangle Map GQ-1174, scale $1: 24,000$.

Honjo, Norio, and Leeman, W.P., 1987, Origin of hybrid ferrolatite lavas from Magic Reservoir eruptive center, Snake River Plain, Idaho: Contributions to Mineralogy and Petrology, v. 96, p. 163-177.

Hotz, P.E., and Willden, Ronald, 1964, Geology and mineral deposits of the Osgood Mountains quadrangle, Humboldt County, Nevada: U.S. Geological Survey Professional Paper 431, $128 \mathrm{p}$.

Ingamells, C.O., 1970, Lithium metaborate flux in silicate analysis: Analytica Chimica Acta, v. 52, p. 323-334.

Joraleman, Peter, 1975, K-Ar relations of granodiorite emplacement and tungsten and gold mineralization near the Getchell mine, Humboldt County, Nevada-A discussion: Economic Geology, v. 70, p. 405-409. 
LaPointe, D.D., Tingley, J.V., and Jones, R.B., 1991, Mineral resources of Elko County, Nevada: Nevada Bureau of Mines and Geology Bulletin 106, 236 p.

McKee, E.H., Tarshis, A.L., and Marvin, R.F., 1976, Summary of radiometric ages of Tertiary volcanic and selected plutonic rocks in Nevada. Part V: Northeastern Nevada: Isochron/West, no. 16, p. 15-27.

Rytuba, J.J., and McKee, E.H., 1984, Peralkaline ash flow tuffs and calderas of the McDermitt volcanic field, southeast Oregon and north central Nevada: Journal of Geophysical Research, v. 89 , p. $8616-8628$.

Silberman, M.L., Berger, B.R., and Koski, R.A., 1974, K-Ar relations of granodiorite emplacement and tungsten and gold mineralization near the Getchell mine, Humboldt County, Nevada: Economic Geology, v. 69, no. 5, p. 646-656.

Stacey, J.S., Sherrill, N.D., Dalrymple, G.B., Lanphere, M.A., and Carpenter, N.V., 1981, A five-collector system for the simultaneous measurement of argon isotopic ratios in a static mass spectrometer: International Mass Spectrometry Ion Physics, v. 39 , p. $167-180$.

Steiger, R.H., and Jäger, E., 1977, Subcommission on Geochronology: Conventions on the use of decay constants in geocosmochronology: Earth and Planetary Science Letters, v. 36, p. 359-362.

Stewart, J.H., and Carlson, J.E., 1978, Geologic map of Nevada: U.S. Geological Survey, scale 1:500,000.

Stewart, J.H., Walker G.W., and Kleinhampl, F.J., 1975, OregonNevada lineament: Geology, v. 3, p. 265-268.

Thorman, C.H., Brooks, W.E., Snee, L.W., Potter, C.J., Dubiel, R.J., and Ketner, K.B., 1993, Late middle Eocene Nanny Creek calc-alkaline volcanic field, NE Nevada and NW Utah: Age, extent, and implications for Eocene tectonics [abs.]: Geological Society of America Abstracts with Programs, v. 25, no. 5 , p. 155.

Wallace, A.R., 1990, Geologic map of the Jake Creek Mountain quadrangle, Elko County, Nevada: U.S. Geological Survey Geologic Quadrangle Map GQ-1672, scale 1:24,000.

1993, Geologic map of the Snowstorm Mountains and vicinity, Elko and Humboldt Counties, Nevada: U.S. Geological Survey Miscellaneous Investigations Series Map I-2394, scale 1:50,000.

Wallace, A.R., McKee, E.H., Zoback, M.L., and Zimmermann, R.A., 1990, New ages for volcanic rocks, western Elko County, Nevada: Isochron/West, no. 55, p. 3-5.

Willden, Ronald, 1964, Geology and mineral deposits of Humboldt County, Nevada: Nevada Bureau of Mines and Geology Bulletin $59,154 \mathrm{p}$.

Zoback, M.L., McKee, E.H., Blakely, R.J., and Thompson, G.A., 1994, The northern Nevada rift: Regional tectono-magmatic relations and middle Miocene stress direction: Geological Society of America Bulletin, v. 106, p. 371-382.

Zoback, M.L., and Thompson, G.A., 1978, Basin and Range rifting in northern Nevada: Clues from a mid-Miocene rift and its subsequent offsets: Geology, v. 6, p. 111-116.

\section{APPENDIX: ANALYTICAL METHODS AND SAMPLE DESCRIPTIONS}

\section{ANALYTICAL METHODS}

$\mathrm{K}$-Ar sample preparation and analyses were done in the laboratories of the U.S. Geological Survey, Menlo Park, Calif. Analyses were by standard isotope dilution procedures as described by Dalrymple and Lanphere (1969). Plagioclase and hornblende concentrates were made by heavy-liquid, magnetic, electrostatic, and hand-picking procedures. The andesite and basaltic andesite samples were ground to 80 to 100 mesh, leached in $\mathrm{HNO}_{3}$ and $\mathrm{HF}$ solutions, and washed and dried immediately before loading in the high-vacuum gas-extraction system. Potassium analyses were performed by lithium metaborate flux fusion flame photometry techniques, the lithium serving as an internal standard (Ingamells, 1970). Argon analyses were performed using a 15.2-cm-radius, Neir-type mass spectrometer or a five-collector mass spectrometer (Stacey and others, 1981). The precision of the data, shown as the " \pm value," is the estimated analytical uncertainty at one standard deviation (Cox and Dalrymple, 1967). It represents uncertainties in the measurement of radiogenic ${ }^{40} \mathrm{Ar}$ and $\mathrm{K}_{2} \mathrm{O}$ based on experience with hundreds of replicated analyses in the Menlo Park laboratories. Mass discrimination of the spectrometer is routinely determined on the basis of multiple analyses of purified air. The constants used in age determination are those from the Subcommission on Geochronology (Steiger and Jäger, 1977).

\section{SAMPLE DESCRIPTIONS}

9LH8: Dacite of Kelly Creek Spring (lat $41^{\circ} 19^{\prime} 51^{\prime \prime} N$., long $117^{\circ} 07^{\prime} 12^{\prime \prime} \mathrm{W}$.; Kenny Creek 7.5-minute quadrangle; Humboldt Co., Nevada); outcrop of dacite welded tuff. Contains broken, 1-mm-long phenocrysts of plagioclase, biotite, hornblende, and sparse opaque minerals, quartz, and sanidine; plagioclase $>>$ sanidine. Groundmass is partially devitrified and composed of weakly compacted angular shards.

9LH11: Andesite of Dry Hills (lat $41^{\circ} 13^{\prime} 30^{\prime \prime} \mathrm{N}$., long $117^{\circ} 11^{\prime} 10^{\prime \prime}$ W.; Dry Hills North 7.5-minute quadrangle; Humboldt Co., Nevada); fresh andesite excavated from trench for pipeline. Aphyric with a very fine grained groundmass of plagioclase, iron oxides, and pyroxene. Drill cuttings from nearby drill hole indicate andesite overlies argillites of presumably Paleozoic age, based upon exposures of contact $2 \mathrm{~km}$ to the southeast.

9LH22: Andesite of Scraper Springs (lat $41^{\circ} 19^{\prime} 38^{\prime \prime} \mathrm{N}$., long $116^{\circ} 40^{\prime} 01^{\prime \prime}$ W.; Scraper Springs 7.5-minute quadrangle, Elko Co., Nevada); andesite flow collected from roadcut at the mouth of Scraper Springs Creek. 
Contains phenocrysts of plagioclase $\left(\mathrm{An}_{45-55}\right)$ and pyroxene; Coats (1987) also reports amphibole. Capped $1.5 \mathrm{~km}$ to the west by andesite breccia, which is overlain by a nonwelded pumice tuff of unknown age and middle Miocene rhyolite flows.

9LH24: Basaltic andesite dike (lat $41^{\circ} 15^{\prime} 34^{\prime \prime} \mathrm{N}$., long $116^{\circ} 48^{\prime} 32^{\prime \prime} \mathrm{W}$; Oregon Canyon 7.5-minute quadrangle; Elko Co., Nevada); outcrop in western part of Midas district. Dike fed flows in lower basaltic andesite sequence in the district. Petrographically similar to 9LH25, but slightly finer grained. Influence of 15.5Ma mineralization in the district is unknown, but the dike is more than $2 \mathrm{~km}$ from the nearest veins, and the date on the dike is consistent both with a 15.2-Ma date to the west (Wallace and others, 1990) and with the relative age of the dike and the 14.7-Ma flows in the upper basaltic andesite sequence (sample 9LH25). However, the high $\mathrm{K}_{2} \mathrm{O}$ content ( 6.43 weight percent) suggests potassic alteration that is not evident in thin sections.

9LH25: Basaltic andesite flow (lat $41^{\circ} 16^{\prime} 49^{\prime \prime} \mathrm{N}$., long $116^{\circ} 47^{\prime} 29^{\prime \prime} \mathrm{W}$.; Oregon Canyon 7.5-minute quadrangle; Elko Co., Nevada); exposure of massive flow unit in roadcut near northern margin of Midas Creek valley. Part of the upper of two basaltic andesite sequences in the Midas area. Contains sparse 1-mmlong plagioclase $\left(A n_{65-75}\right)$, olivine, orthopyroxene, and clinopyroxene phenocrysts in fine-grained groundmass of the same minerals. Two $\mathrm{km}$ to south, unit overlies intervening pyroclastic rocks; less than $500 \mathrm{~m}$ to west, unit overlain by basal rhyolite flow of the younger bimodal sequence. 


\title{
${ }^{40} \mathrm{Ar} /{ }^{39} \mathrm{Ar}$ AND U-Th-Pb AGES ASSOCIATED WITH BASE- AND PRECIOUS-METAL DEPOSITS IN CENTRAL IDAHO
}

\author{
By Karl V. Evans, ${ }^{1}$ Lawrence W. Snee, ${ }^{2}$ and Robert E. Zartman ${ }^{2}$
}

\begin{abstract}
${ }^{40} \mathrm{Ar} /{ }^{39} \mathrm{Ar}$ analysis of muscovite from quartz fissurevein gold and base-metal deposits at the Mammoth mine in west-central Idaho yields a plateau age of $69 \mathrm{Ma}$. Other argon analyses of biotite and a whole-rock sample from the Bobcat Gulch porphyry copper-molybdenum prospect in east-central Idaho indicate an age of mineralization of about $49 \mathrm{Ma}$. These results confirm a growing body of evidence that both the Late Cretaceous and middle Eocene were times of significant metallic mineral deposition in Idaho. U-Th- Pb analyses of zircon from a rhyolite sill within the Yellowjacket Formation at the West Fork Indian Creek gold prospect in east-central Idaho yield an essentially concordant age of $47 \mathrm{Ma}$, confirming previous suggestions that the rhyolite is part of the Challis volcanic-plutonic event; the age of gold deposition at the prospect remains unknown.
\end{abstract}

\section{INTRODUCTION}

In the course of studies by the U.S. Geological Survey (USGS), during which the geology and mineral resource potential of current and proposed Wilderness Areas were investigated, several mineral deposits were sampled to provide information regarding the age of base- and preciousmetals deposition. This report provides a brief description of the geologic setting, analytical data, and interpretations of the results. Isotopic techniques follow Snee (1982), Snee and others (1988), and Evans and Zartman (1990). Age calculations are based on the decay constants of Steiger and Jäger (1977).

Acknowledgments.-We would like to thank Paul de Renne (consulting geologist) for providing information and

${ }^{1}$ U.S. Geological Survey, Mail Stop 905, P.O. Box 25046, Denver Federal Center, Denver, CO 80225.

${ }^{2}$ U.S. Geological Survey, Mail Stop 963, P.O. Box 25046, Denver Federal Center, Denver, CO 80225. access to the West Fork Indian Creek prospect and Cominco American for allowing Robert C. Pearson (USGS) to collect the core sample from Bobcat Gulch. Discussions with Norm Lavery (consulting geologist), Bob Pearson, and Karen Lund improved our understanding of the mineral deposits. Ed DeWitt and Bob Pearson reviewed the manuscript.

\section{MAMMOTH MINE}

The Mammoth mine is in the Dixie mining district, about $1.5 \mathrm{~km}$ from the boundary of the Cove Mountain addition to the Frank Church-River of No Return Wilderness (fig. 1). The mine operated intermittently from 1932 to 1963 , producing as much as $1,000 \mathrm{oz}$ each of gold and silver, up to $500 \mathrm{lbs}$ each of copper and lead, and an unknown amount of zinc (Mitchell and others, 1991). The host rock for the deposit is Cretaceous biotite-muscovite granite of the Idaho batholith (Lund and others, 1986; Lund and Esparza, 1990). At the Mammoth mine, the granite shows intense sericitic alteration and silicification, with numerous gold- and basemetal-bearing quartz veins that range from several centimeters to nearly $1 \mathrm{~m}$ in width (Capps and Roberts, 1939).

Muscovite from the quartz veins is cogenetic with orebearing sulfide minerals; its age, therefore, should yield the time of metal deposition. A ${ }^{40} \mathrm{Ar} /{ }^{39} \mathrm{Ar}$ plateau date of $69.5 \pm 0.5 \mathrm{Ma}$ ( 1 sigma error) (table 1; fig. $2 A$ ) indicates that ore deposition at the Mammoth mine is Late Cretaceous, similar in setting and age to deposits in the nearby Buffalo Hump mining district (Lund and others, 1986) and numerous other mining districts in central Idaho (Snee and others, 1991).

\section{BOBCAT GULCH PROSPECT}

The Bobcat Gulch prospect is a copper-molybdenum porphyry target located about $28 \mathrm{~km}$ northeast of the Special Mining Management Zone-Clear Creek of the Frank 


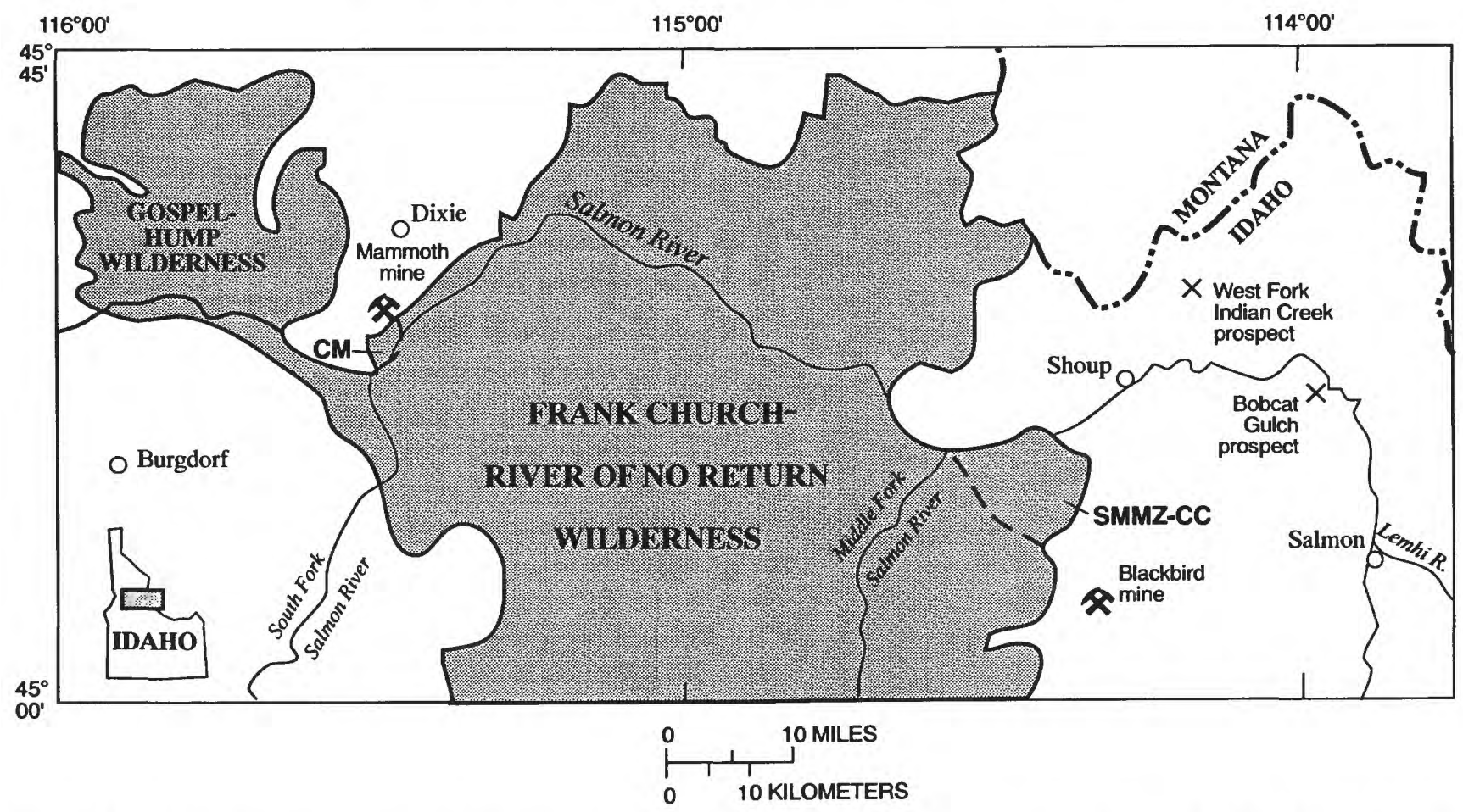

Figure 1. Index map of central Idaho showing sample localities and geographic features mentioned in text. CM, Cove Mountain addition to the Frank Church-River of No Return Wilderness; SMMZ-CC, Special Mining Management Zone-Clear Creek (Lund and others, 1983).
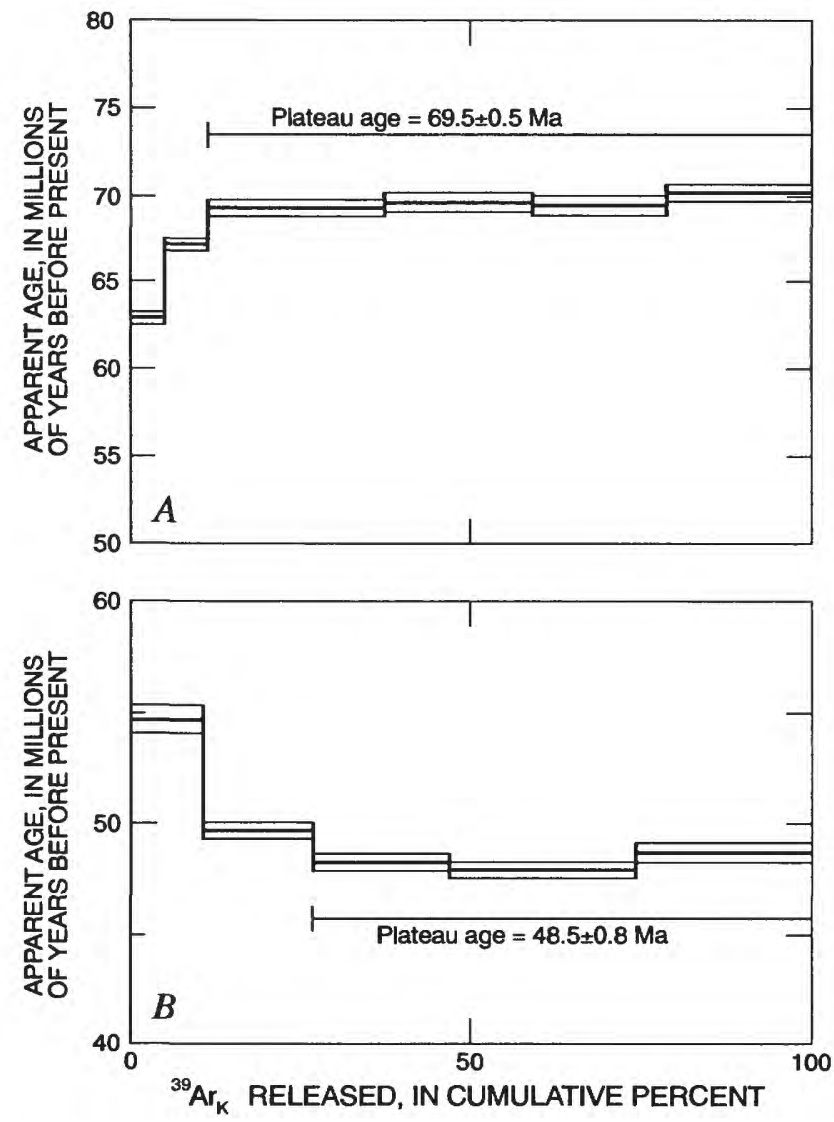

Church-River of No Return Wilderness (Lund and others, 1983). Cominco American (Bunning and Burnet, 1981) drilled several holes between 1977 and 1981; Nisbet and Scales (1990) later interpreted the data as defining 40 million tons of 0.40 -percent copper, but the prospect has not been developed further. Copper and molybdenum minerals are associated with several intrusive phases, ranging from rhyolite to quartz diorite, that exhibit various stages of alteration (Bunning and Burnet, 1981; Loen and Pearson, 1989; Pearson and others, 1992).

Biotite and a whole-rock sample from a diamond drill core yield similar ages by the ${ }^{40} \mathrm{Ar} /{ }^{39} \mathrm{Ar}$ method. Biotite phenocrysts from fresh to very slightly altered rhyolite porphyry give a total-gas date of $49.1 \pm 0.5 \mathrm{Ma}$ (table 1 ). A whole-rock sample from the same drill hole (1497-1538- $\mathrm{ft}$ interval) is an altered and mineralized mafic dike consisting of clinopyrox-

Figure 2 (facing column). ${ }^{40} \mathrm{Ar} /{ }^{39} \mathrm{Ar}$ age spectrum diagrams for samples from Mammoth mine and Bobcat Gulch prospect. Ages for each heating step are shown as horizontal lines with 1 sigma error bars. ${ }^{39} \mathrm{Ar}_{\mathrm{K}}$ indicates the ${ }^{39} \mathrm{Ar}$ produced from ${ }^{39} \mathrm{~K}$ during irradiation. $A$, Muscovite from quartz veins at the Mammoth mine (sample IB20-83). $B$, Whole-rock sample of mafic dike from drill core at the Bobcat Gulch prospect (sample 80PO61). 
Table 1. ${ }^{40} \mathrm{Ar} /{ }^{39} \mathrm{Ar}$ data for samples from Mammoth mine and Bobcat Gulch prospect.

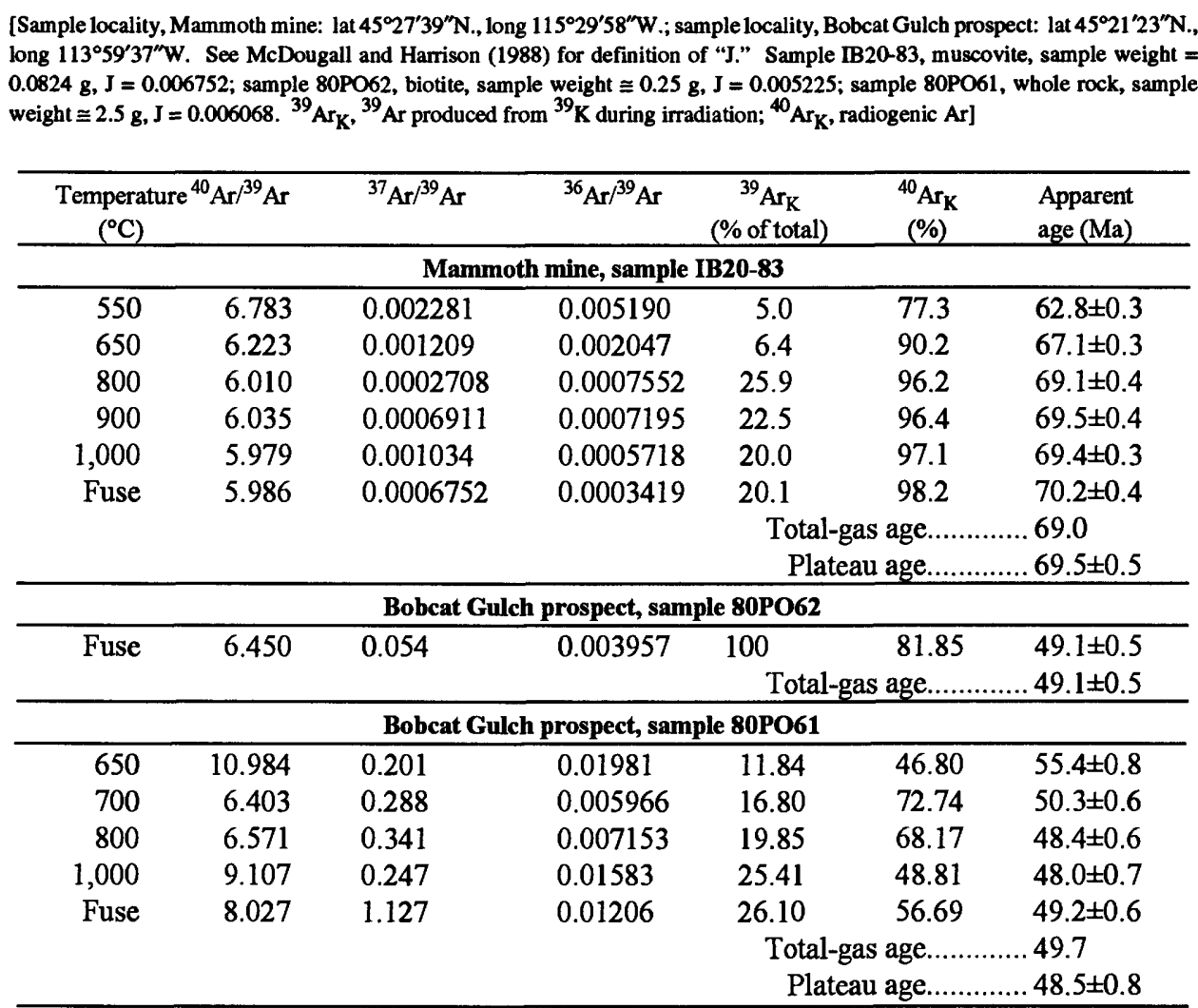

ene, brown hornblende, biotite, and plagioclase (albite), with minor quartz completely replacing some phenocrysts (clinopyroxene?). Plagioclase laths are slightly ragged and irregularly shaped. Alteration phases include minor carbonate minerals, clays, and pyrite; much of the fine-grained material is unidentifiable. Because adequate mineral separates could not be obtained from the fine-grained altered core, the whole rock was analyzed. This sample yields a plateau date of $48.5 \pm 0.8 \mathrm{Ma}$; the total-gas date is $49.7 \mathrm{Ma}$. The shape of the age spectrum suggests minor excess argon (fig. $2 B$ ). Both plateau dates are identical within analytical error and indicate that the $\mathrm{Cu}$ and $\mathrm{Mo}$ mineralization is related to the Eocene Challis volcanic and plutonic event. Curiously, a very nearby gold deposit developed in sheared Proterozoic quartzite has been dated by conventional $\mathrm{K}$-Ar methods on sericite at $69 \mathrm{Ma}$ (Nisbet and Scales, 1990). The latter date is similar to the age of the Beartrack gold deposit at Leesburg (K.V. Evans and L.W. Snee, unpub. data) but is distinctly different from that at Bobcat Gulch.

\section{WEST FORK INDIAN CREEK PROSPECT}

The West Fork Indian Creek prospect is about $15 \mathrm{~km}$ northeast of Shoup, Idaho (fig. 1). Recent drilling by an independent exploration and management company has demonstrated the presence of gold mineralization (P. de Renne, consulting geologist, oral commun., 1990); however, we are not aware of public information regarding the size and grade of the deposit. Rocks in the area of exploration are strata of the Middle Proterozoic Yellowjacket Formation, at least some of which is recognizable as the middle unit of that formation (Connor and Evans, 1986; Evans, in press; Evans and Connor, 1993). Reconnaissance mapping by Lopez (1982) characterizes an area of the West Fork drainage as being mixed Yellowjacket strata and Tertiary rhyolitic dikes. However, some of the "dikes" are strictly parallel to bedding, and core logging has indicated that they might be spherulitic, thyolite ash-flow tuffs, apparently with alteration developed only on one side of the "tuff" (N.G. Lavery, consulting geologist, oral and written commun., 1990). If the rhyolites are tuffs, they would provide an excellent means to date the sedimentary rocks of the Yellowjacket and perhaps relate the gold deposit to a Proterozoic mineralizing system such as those known in the region at the Blackbird (Nash and others, 1987) and Ulysses mines (Chevillon and Herberger, 1989). Because field, drill-core, and even thin-section data remained equivocal, rhyolite from a fresh roadcut through one of the bodies was sampled for $\mathrm{U}-\mathrm{Th}-\mathrm{Pb}$ analysis of zircon.

Two splits of hand-picked zircon demonstrate that the rhyolite is Eocene in age and corroborate Lopez's (1982) original field interpretation. One zircon split (split A, table 2 
Table 2. U-Th-Pb zircon data for rhyolite from West Fork Indian Creek prospect.

[Sample locality: lat $45^{\circ} 29^{\prime} 05^{\prime \prime} \mathrm{N}$., long $114^{\circ} 10^{\prime} 29^{\prime \prime} \mathrm{W}$. Isotopic composition of common lead is assumed to be ${ }^{204} \mathrm{~Pb}:{ }^{206} \mathrm{~Pb}:{ }^{207} \mathrm{~Pb}:{ }^{208} \mathrm{~Pb}=1: 18.63: 15.63: 38.54$. Split A: elongate, euhedral crystals with average length-to-width ratio of 6:1; split B: nearly equant, euhedral crystals with average length-to-width ratio of 1.6:1. Crystal diameters are from 20 to $50 \mu \mathrm{m}]$

\begin{tabular}{|c|c|c|c|c|c|c|c|c|c|c|c|c|}
\hline & $\begin{array}{c}\text { Sample } \\
\text { weight } \\
(\mu \mathrm{g})\end{array}$ & \multicolumn{3}{|c|}{$\begin{array}{l}\text { Concentration } \\
\text { (ppm) }\end{array}$} & \multicolumn{4}{|c|}{$\begin{array}{l}\text { Isotopic composition of } \\
\text { lead (atom percent) }\end{array}$} & \multicolumn{4}{|c|}{$\begin{array}{c}\text { Age } \\
\text { (millions of years before present) }\end{array}$} \\
\hline Split A & 44.8 & 925.6 & 430.7 & 7.796 & 0.1117 & 77.01 & 5.279 & 17.60 & $47.1 \pm 0.8$ & $47.3 \pm 0.9$ & $57 \pm 13$ & $54.6 \pm 0.8$ \\
\hline
\end{tabular}

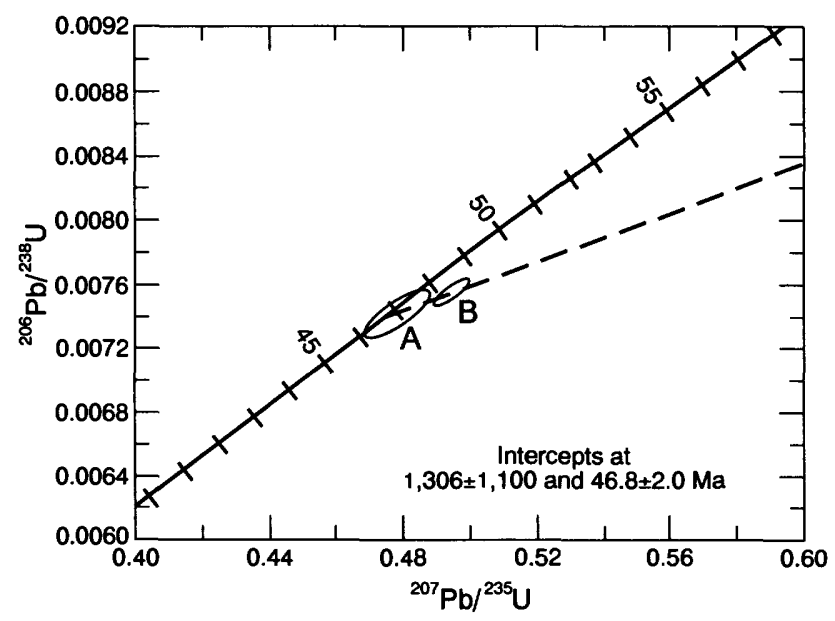

Figure 3. Concordia diagram for zircon from rhyolite at the West Fork Indian Creek prospect (sample 48-9KE-103B). Error ellipses plotted using procedure of Ludwig (1988). " $A$ " indicates error ellipse for elongate, euhedral zircon crystals (split A). "B" indicates error ellipse for nearly equant, euhedral zircon crystals (split B).

-elongate, euhedral crystals with average length-to-width ratio of 6:1) is essentially concordant within analytical error, and the second split (split B, table 2-nearly equant, euhedral crystals with average length-to-width ratio of $1.6: 1$ ) is only slightly discordant. Taken together, both splits suggest the presence of a minor component of inherited Precambrian radiogenic lead in the zircon (fig. 3, table 2) with the greater proportion residing in the more equant crystals. This phenomenon is probably best explained as arising from the incorporation into the rhyolite of a small amount of xenocrystic zircon derived from the surrounding country rock. The xenocrystic zircon then served as nuclei for newly crystallizing overgrowths of the same mineral. A crystallization age of $46.8 \pm 2 \mathrm{Ma}$ (fig. 3 ) is considered the best time estimate for the emplacement and solidification of the rhyolite. At present, the age of the gold deposit remains undetermined.

\section{DISCUSSION}

Prior to the advent of modern isotopic geochronology, the ages of mineral deposits in Idaho were often extremely difficult to ascertain. Because several deposits were hosted in volcanic rocks of the Tertiary Challis Volcanic Group, geologists tended to promote a very strong bias that most deposits were Tertiary (see Lund and others, 1986, for a brief historical account). Recent geochronologic studies have clearly identified a Late Cretaceous period of mineralization (Snee and others, 1991) in addition to the well-documented Tertiary events. The present study adds to this growing database and confirms the complex history of mineralization in Idaho. Data from the Mammoth mine are consistent with numerous other Late Cretaceous dates of mineralization throughout central Idaho. The Bobcat Gulch data confirm the importance of Eocene intrusive and volcanic rocks as ore-producing systems. The significance of the zircon date of the rhyolite at the West Fork Indian Creek is unclear with respect to the drilled mineral deposit. Dating of appropriate alteration minerals directly associated with the deposit will probably be needed to resolve the age of mineralization.

\section{REFERENCES CITED}

Bunning, B.B., and Burnet, F.W., 1981, Copper-molybdenum mineralization in the Bobcat Gulch porphyry system, Lemhi County, Idaho: Unpublished paper presented at the 87th Annual Northwest Mining Association Convention, Spokane, Washington, Dec. 5, 1981.

Capps, S.R., and Roberts, R.J., 1939, The Dixie placer district, Idaho, with notes on the lode mines: Idaho Bureau of Mines and Geology Pamphlet No. 48, 35 p.

Chevillon, V., and Herberger, D.J., 1989, Syngenetic gold mineralization in the Proterozoic Yellowjacket Formation, Ulysses gold mine, Lemhi County, Idaho [abs.]: Geological Society of America, Abstracts with Programs, v. 21, no. 5, p. 65.

Connor, J.J., and Evans, K.V., 1986, Geologic map of the Leesburg quadrangle, Lemhi County, Idaho: U.S. Geological Survey Miscellaneous Field Studies Map MF-1880, scale 1:62,500.

Evans, K.V., in press, The Yellowjacket Formation of east-central Idaho, in Berg, R.B., ed., Proceedings of Belt Symposium III: Montana Bureau of Mines and Geology Special Publication.

Evans, K.V., and Connor, J.J., 1993, Geologic map of the Blackbird Mountain 15-minute quadrangle, Lemhi County, Idaho: U.S. Geological Survey Miscellaneous Field Studies Map MF-2234, scale 1:62,500. 
Evans, K.V., and Zartman, R.E., 1990, U-Th-Pb and Rb-Sr geochronology of Middle Proterozoic granite and augen gneiss, Salmon River Mountains, east-central Idaho: Geological Society of America Builetin, v. 102, p. 63-73.

Loen, J.S., and Pearson, R.C., 1989, Map showing locations of mines and prospects in the Dillon $1^{\circ} \times 2^{\circ}$ quadrangle, Idaho and Montana: U.S. Geological Survey Miscellaneous Investigations Series Map I-1803-C, scale 1:250,000.

Lopez, D.A., 1982, Reconnaissance geologic map of the Ulysses Mountain quadrangle, Lemhi County, Idaho: U.S. Geological Survey Miscellaneous Field Studies Map MF-1445, scale 1:48,000.

Ludwig, K.R., 1988, ISOPLOT for MS-DOS: A plotting and regression program for radiogenic-isotope data, for IBM-PC compatible computers, version 2.0 [revision as of January 3 , 1990]: U.S. Geological Survey Open-File Report 88-557, $35 \mathrm{p}$.

Lund, K., and Esparza, L.E., 1990, Mineral resources of the Gospel-Hump Wilderness, Idaho County, Idaho: U.S. Geological Survey Bulletin 1812, 19 p.

Lund, K., Evans, K.V., and Esparza, L.E., 1983, Mineral resource potential map of the Special Mining Management Zone--Clear Creek, Lemhi County, Idaho: U.S. Geological Survey Miscellaneous Field Studies Map MF-1576-A, scale 1:50,000.

Lund, K., Snee, L.W., and Evans, K.V., 1986, Age and genesis of precious metals deposits, Buffalo Hump district, central Idaho: Implications for depth of emplacement of quartz veins: Economic Geology, v. 81, p. 990-996.

McDougall, Ian, and Harrison, T.M., 1988, Geochronology and Thermochronology by the ${ }^{40} \mathrm{Ar} /{ }^{39} \mathrm{Ar}$ Method: New York, Oxford University Press, $212 \mathrm{p}$.

Mitchell, V.E., Vance, R.E., and Bennett, E.H., 1991, Mines and prospects of the Elk City quadrangle, Idaho ( $2 \mathrm{~d}$ ed.): Idaho Geological Survey Mines and Prospects Map Series, 83 p., scale 1:250,000.
Nash, J.T., Hahn, G.A., and Saunders, J.A., 1987, The occurrence of gold in siliceous $\mathrm{Co}-\mathrm{Cu}$ exhalite deposits of the Blackbird mining district, Lemhi County, Idaho: U.S. Geological Survey Open-File Report 87-410, 14 p.

Nisbet, P., and Scales, W.G., 1990, Descriptive road log, northeastern Leesburg Basin-Bobcat project area, in Moye, F.J., ed., Geology and Ore Deposits of the Trans-Challis Fault System/Great Falls Tectonic Zone: Guidebook of the 15th Annual Tobacco Root Geological Society Field Conference, Salmon, Idaho, August 16-18, 1990, p. 45-54.

Pearson, R.C., Trautwein, C.M., Moll, S.H., Berger, B.R., Hanna, W.F., Loen, J.S., Rowan, L.C., Ruppel, E.T., and Segal, D.B., 1992, Maps showing mineral resource assessment for copper and molybdenum in porphyry and stockwork deposits and for tungsten, iron, gold, copper, and silver in skarn deposits, Dillon $1^{\circ} \times 2^{\circ}$ quadrangle, Idaho and Montana: U.S. Geological Survey Miscellaneous Investigations Series Map I-1803-G, scale $1: 250,000$.

Snee, L.W., 1982, Emplacement and cooling of the Pioneer batholith, southwestern Montana: Columbus, Ohio State University, unpub. Ph.D. thesis, 320 p.

Snee, L.W., Lund, K., Evans, K.V., Gammons, C.H., and Kunk, M.J., $1991,{ }^{40} \mathrm{Ar} /{ }^{39} \mathrm{Ar}$ thermochronology of fracture-controlled mineral deposits of the Idaho batholith-Age, thermal history, and origin: U.S. Geological Survey Circular 1062, p. 74-76.

Snee, L.W., Sutter, J.F., and Kelly, W.C., 1988, Thermochronology of economic mineral deposits: Dating the stages of mineralization at Panasqueira, Portugal, by high-precision ${ }^{40} \mathrm{Ar} /{ }^{39} \mathrm{Ar}$ age spectrum techniques on muscovite: Economic Geology, v. 83, p. 335-354.

Steiger, R.H., and Jäger, E., 1977, Subcommission on geochronology: Convention on the use of decay constants in geo- and cosmochronology: Earth and Planetary Science Letters, v. 36, p. 359-362. 



\title{
CHAPTER D
}

\section{GEOLOGY AND MINERAL DEPOSITS IN THE TERRILL MOUNTAINS AREA, HOLY CROSS DISTRICT, CHURCHILL COUNTY, NEVADA}

\author{
By Stephen G. Peters, ${ }^{1}$ Richard F. Hardyman, ${ }^{1}$ and Katherine A. Connors ${ }^{1}$
}

\section{INTRODUCTION}

The Terrill Mountains, between Fallon and Schurz in western Nevada (fig. 1), contain numerous silver-gold veins hosted in Tertiary volcanic, volcaniclastic, and hypabyssal rocks. These veins are spatially associated with copper, lead, zinc, and manganese deposits. Mineral deposits in the Terrill Mountains were discovered in 1910 (Lincoln, 1923; Vanderburg, 1940), and mining in the area has been intermittent from that time to the present. These mineral occurrences, which constitute the southern part of the Holy Cross mining district, are located in the central part of the Terrill Mountains. The northern part of the district, $7 \mathrm{~km}$ to the northeast in the Barnett Hills, is separated from the southern part by Rawhide Flats, a northwest-trending valley thought by us to conceal a major northwest-trending strike-slip fault (see Bingler, 1978; Hardyman, 1980). Early production records are incomplete (Schraeder, 1947), but reported production since 1934 is $74,000 \mathrm{oz}$ silver, $282 \mathrm{oz}$ gold, and $34,000 \mathrm{lbs}$ lead, and minor zinc and copper, from approximately 2,000 tons of ore (Willden and Speed, 1974).

This study was initiated using 1:5,000-scale geologic mapping and rock geochemistry in both the north and south parts of the Holy Cross district in order to investigate the geological, geochemical, and lode characteristics on each side of the inferred strike-slip fault. This study is part of a larger regional study of the central Walker Lane (Hardyman and Oldow, 1991; Hardyman, unpub. mapping, 1983-93; Peters, unpub. mapping, 1992). Comparison of geologic and mineralization characteristics allows speculation on the timing and genetic relationships between the two parts of the mining district. The results of this study also allow comparison of the Holy Cross district with the larger Rawhide gold-

${ }^{1}$ U.S. Geological Survey, Mackay School of Mines, Mail Stop 176, Reno, NV 89557-0047. silver district, located $20 \mathrm{~km}$ to the southeast in a similar geologic setting (cf., Ross, 1961; Black and others, 1991). The purpose of this report is to summarize geologic relationships in the Terrill Mountains part of the Holy Cross mining district and to discuss the relationship of mineral deposits to Walker Lane-style strike-slip and other faulting and to Tertiary volcanism and plutonism.

\section{REGIONAL SETTING}

The Terrill Mountains area is within the central part of the Walker Lane structural zone of western Nevada (fig. 1). This zone contains a composite set of major northwest-striking faults that dissect 30- to 3-Ma (Tertiary) igneous and sedimentary sequences that unconformably overlie faulted and locally deformed and metamorphosed Paleozoic and Mesozoic sedimentary and volcanic basement rocks and intrusive Mesozoic plutons. Pre-Tertiary tectonism of these units involved several periods of thrusting from middle Paleozoic to middle Mesozoic time - this tectonism, toward the end of thrusting, was accompanied by transpressional faulting (Oldow and others, 1989).

Tertiary tectonic evolution has been interpreted by Hardyman and Oldow (1991) to involve a change in the regional least principal stress direction from north-northeast to eastwest to northwest-southeast from 28 to $8 \mathrm{Ma}$. This extension was variously accompanied by normal, strike-slip, and associated detachment faulting. Tertiary faulting was partitioned differently throughout the central Walker Lane, resulting in several structural domains, which are defined by the relationship of tilting between basement rocks and overlying Tertiary sequences. Domains where basement rocks and overlying Tertiary sections were tilted together can be documented in some areas. In other areas associated with large strike-slip faulting, domains are typified by tilted Tertiary strata that lie in fault contact above non-tilted basement 


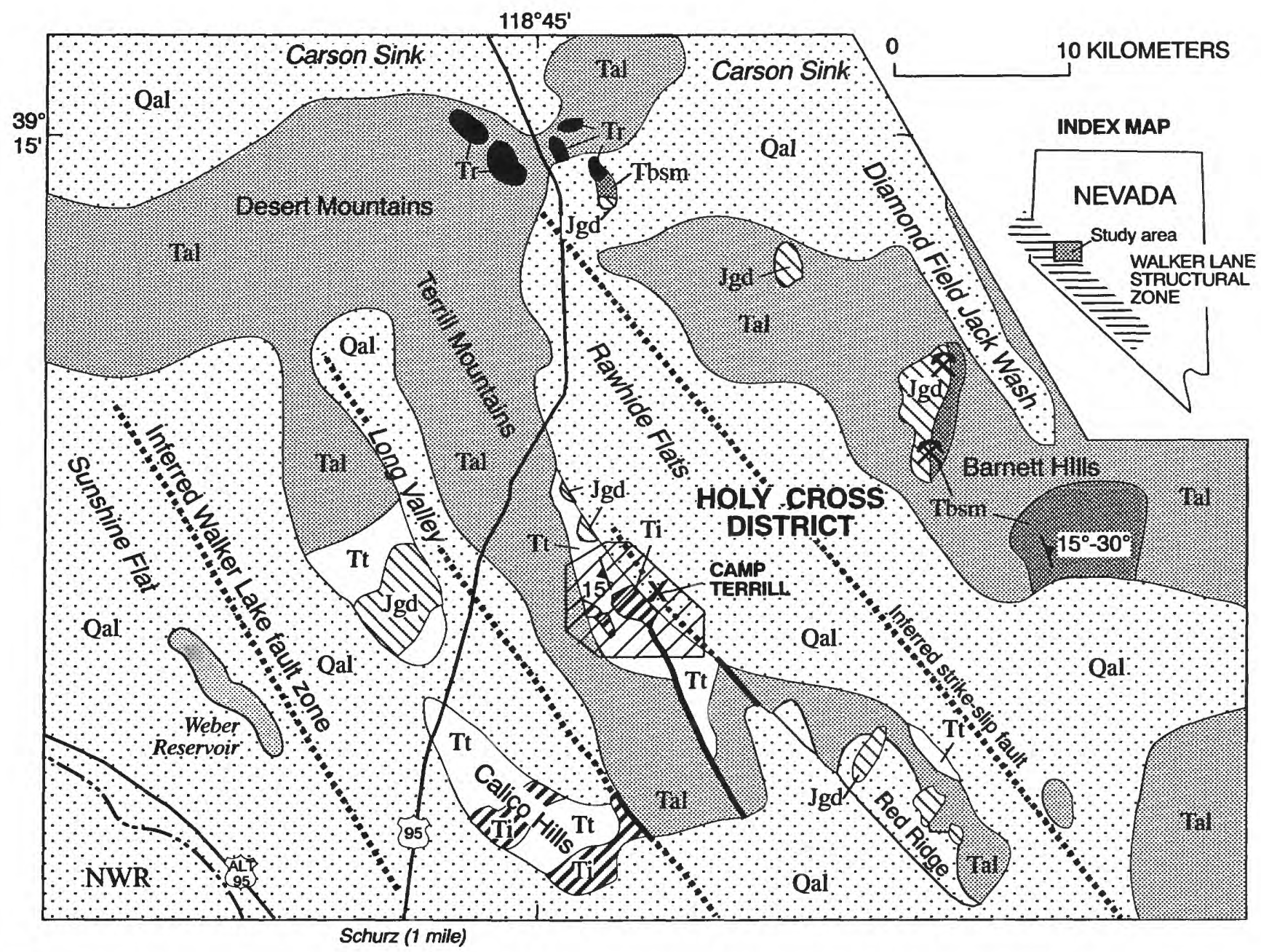

Figure 1. Index map of western Nevada showing the Walker Lane structural zone (inset) and generalized regional geologic map of the Terrill Mountains. Map units: Qal, Quaternary alluvium; Tbsm, Tertiary ash-flow tuffs of the Blow Sand Mountains; Tt, Tertiary ash-flow tuffs of uncertain correlation; Tal, younger Tertiary andesite lavas and lahars and younger basaltic andesite and basalt lavas unconformably overlying the ash-flow tuff sequences; Tr, Tertiary rhyolite intrusions; Ti, Tertiary hypabyssal dacite intrusions in the eastern part of the Terrill Mountains and the southern Calico Hills; Jgd, Jurassic(?) basement rocks. NWR, northern Wassuk Range; solid heavy lines are faults; heavy dotted lines are inferred concealed faults or extensions of mapped faults in bedrock. Area on map near Camp Terrill shown by diagonal lines is area shown in figures 2 and 3. Regional geologic map modified after Hardyman and others (1992).

rocks. The Terrill Mountains area is a fault-bounded structural block, which is interpreted by Hardyman and others (1992) as tilted Tertiary strata lying upon non-tilted pre-Tertiary basement rocks (see Dilles and others, 1993; Hardyman and others, 1992).

\section{GEOLOGY}

The Terrill Mountains rise approximately $600 \mathrm{~m}$ above the valley floor of Rawhide Flats and consist of widespread exposures of late Oligocene to earliest Miocene silicic ashflow tuffs and early Miocene hypabyssal dacite intrusions.
These rocks are unconformably overlain by middle Miocene hornblende-andesite lahars and pyroxene andesite and olivine-basalt lava flows. Except in local areas adjacent to some intrusive dacite contacts or faults where compaction foliation is steep to moderate, the Tertiary volcanic section exposed in the Terrill Mountains has a generally gentle (approximately $15^{\circ}$ ) west-southwest dip.

Limited exposures of Mesozoic (Jurassic?) gabbro and diorite are found along the eastern range front, approximately $2.8 \mathrm{~km}$ northwest of Camp Terrill (fig. 2). Some of these Mesozoic basement rocks are in contact with the southeastern part of a 4-km-long by $0.9-\mathrm{km}$-wide, northwesttrending, ash-flow tuff/fissure-vent complex that intrudes 


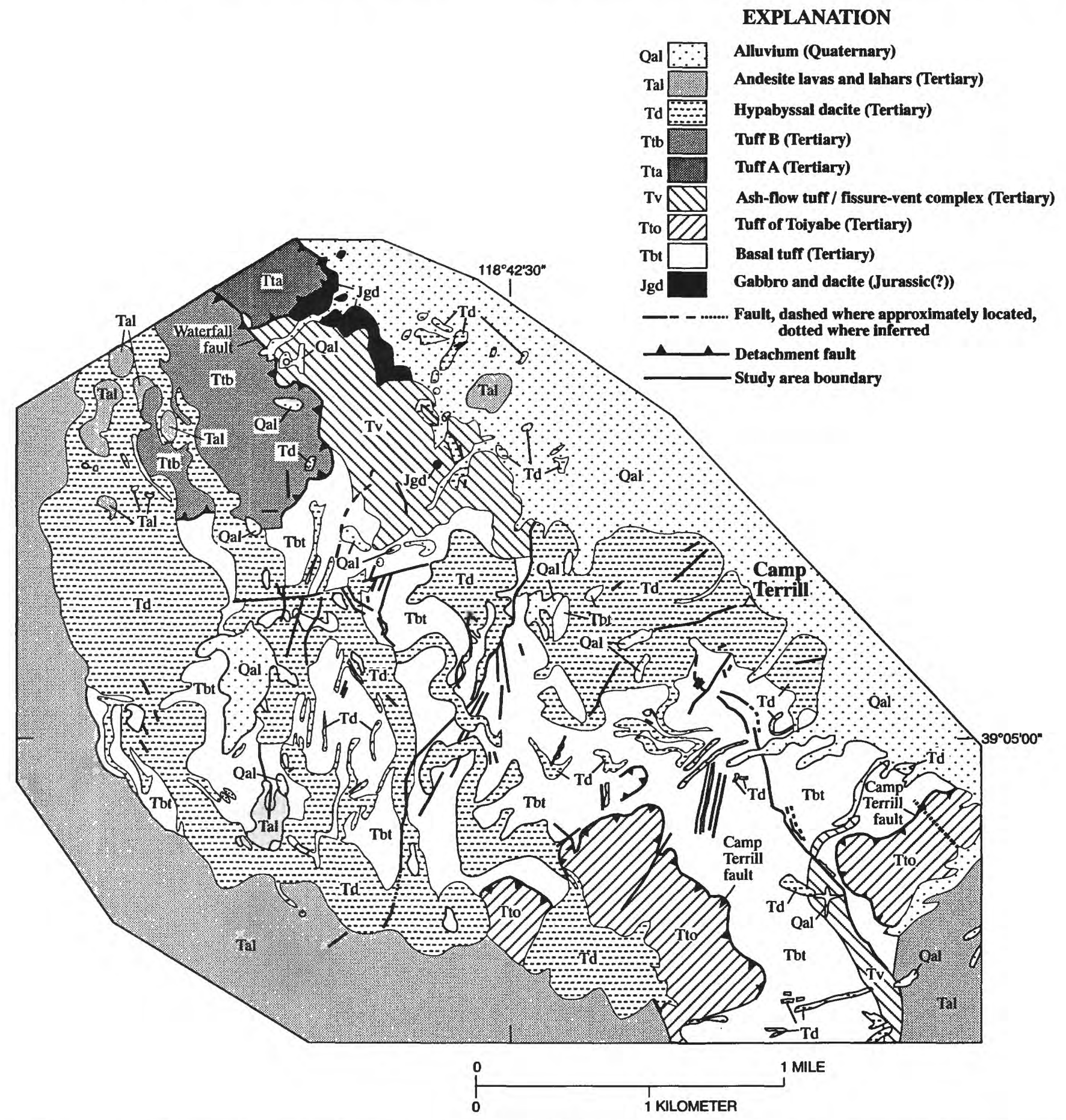

Figure 2. Simplified geologic map of the Terrill Mountains area, southern Holy Cross mining district, showing main geologic units and faults.

older, lower tuff units and may locally intrude the gabbro and diorite. Elsewhere, contacts between the gabbro and diorite unit and the Tertiary volcanic rocks are, for the most part, low-angle detachment faults. Steep faults trend northwest and north-northwest and further dismember the Mesozoic-Tertiary rock contact (fig. 2).

\section{LITHOLOGY}

Jurassic(?) gabbro and diorite ( $\mathrm{Jgd}$ ).--These rocks comprise the oldest recognized unit in the Terrill Mountains (fig. 2). Much of the rock is a medium-grained hornblende gabbro with oligoclase and minor clinopyroxene, biotite, 
lesser apatite, sphene, and opaques. The rock is massive and undeformed but contains local 1 - to $10-\mathrm{m}^{2}$ areas of metasomatism that are characterized by massive scapolite with lesser albite, brown garnet, and epidote. The nearest rocks of similar type are the 165- to 145-Ma (Middle Jurassic) lopolithic gabbros located $100 \mathrm{~km}$ to the northeast, in the Mopung Hills, Clan Alpine Mountains, and in the West Humboldt Mountains (Willden and Speed, 1974). No direct correlation has been made between these similar rocks.

Basal tuff $(T b t)$.- The basal tuff hosts the majority of the mineral deposits in the Terrill Mountains and is the basal unit of the Tertiary section (fig. 2). A thickness of approximately $200 \mathrm{~m}$ of this unit is exposed in the east flank of the range. The base of the unit is either covered by Quaternary deposits or intruded by hypabyssal dacite. The unit is nowhere exposed in contact with the Jurassic(?) gabbro and diorite (Jgd) basement rocks. The basal tuff is unconformably overlain, in low-angle detachment-fault contact, by the tuff of Toiyabe (Tto) and tuff B (Ttb) (fig. 2). The basal tuff consists of two main cooling units of felsic ash-flow tuff with additional, truncated cooling units present at the base of and capping the exposed section. Mapped in detail, the basal tuff can be subdivided into seven individual 20 - to $30-\mathrm{m}$ thick horizons that are distinguishable by color, degree of welding, pumice and crystal content, and by specific ingredients such as local sedimentary rock lenses or wood shards. The central part of the basal tuff hosts the majority of the silver-gold mineral deposits, localized at the contact between porous, white, volcanic-pebble conglomerate and an overlying densely welded tuff member. The basal tuff unit is undated in the Terrill Mountains and has not been correlated with units outside the Terrill Mountains.

Tuff of Toiyabe (Tto).-The 23- to 22-Ma tuff of Toiyabe is exposed in two areas south and southeast of Camp Terrill (fig. 2). The easternmost exposure overlies, and is in low-angle detachment-fault contact with the lower members of the basal tuff as described by Hardyman and others (1992). To the southwest, exposures of the tuff of Toiyabe are in low-angle detachment-fault contact with the upper members of the basal tuff (fig. 2). The tuff of Toiyabe is a gray- to brown-weathering, densely welded, devitrified, massive, and crystal-rich (quartz and feldspar) ash-flow tuff. The presence of relatively abundant sphene (up to $4 \mathrm{~mm}$ long) recognized in hand specimen is a distinguishing characteristic of the tuff. The upper part of the unit is eroded and is unconformably overlain by hornblende-andesite lahars. The unit is locally hydrothermally altered and mineralized along the detachment fault (the Camp Terrill fault of Hardyman and others, 1992). The source of the tuff of Toiyabe is the Toiyabe caldera, located in the southern Toiyabe Range, approximately $110 \mathrm{~km}$ to the southeast along the Walker Lane (Bremm and others, 1985, 1991).

Tuff A (Tta).- This unit is exposed in the extreme northwestern part of the study area (fig. 2) and extends about 2.5 $\mathrm{km}$ northwest along the range front, beyond the map area.
Tuff $A$ is a relatively massive red to reddish-brown-weathering, crystal-rich, rhyolite ash-flow tuff that overlies pre-Tertiary gabbro and diorite in low-angle fault contact. It is intruded by crystal-poor fissure-vent/ash-flow tuff (unit Tv, fig. 2) and is separated from tuff B to the west by a northwest-striking high-angle fault (fig. 2).

The stratigraphic position of tuff $A$ is uncertain because it is nowhere in depositional contact with other Tertiary volcanic units within the Terrill Mountains and it has yet to be correlated with other ash-flow tuffs in the region. Mineralogically, it resembles a tuff in the northern Wassuk Range, approximately $30 \mathrm{~km}$ west-southwest of the Terrill Mountains, which has been dated at 28.6 Ma (Dilles and others, 1993).

Tuff $B(T t b)$.-This map unit is approximately $60-\mathrm{m}$ thick and consists of four concordant and petrologically similar cooling units, which can be divided into seven distinct horizons. The rock types consist of light-brown- and lightgray-weathering, densely welded to moderately welded, devitrified, crystal-rich, moderately biotite rich, quartz-latite ash-flow tuffs. The lower four horizons are poorly welded, green-, purple-, and buff-colored pebble and cobble conglomerate and volcaniclastic rocks. The upper three horizons are black vitrophyre, light-brown, welded, crystal-rich tuff, and white, poorly welded, fine-grained, epiclastic tuff. The top of the unit is capped by intrusive dacite or is eroded. Tuff $B$ is in fault contact with other ash-flow tuff units in the study area and is intruded by rocks of the ash-flow tuff/fissure-vent complex (Tv) and by hypabyssal dacite (Td); the unit was subsequently faulted. The unit dips about $15^{\circ}-20^{\circ}$ southwest and is unmineralized. No regional correlation of this tuff unit has been recognized.

Ash-flow tufflfissure-vent complex (Tv).-An ash-flow tuff/fissure-vent complex is exposed for approximately 4 $\mathrm{km}$ along the east flank of the Terrill Mountains (Hardyman and others, 1992; Dilles and others, 1993). A 2-km-long exposure within the study area, approximately $2 \mathrm{~km}$ northwest of Camp Terrill (fig. 2), is composed of two, crystalpoor rhyolite units ( $<5$ volume percent crystals). Most of the western part of the fissure-vent complex within the map area (fig. 2) and that part of the fissure-vent complex north of the map area consists of lavender- to gray- and reddishbrown-weathering, devitrified, pyroclastic rhyolite containing recognizable pumice lapilli and "bubble-wall" glass shards. The pyroclastic rhyolite grades into red- and redbrown-weathering flow-laminated rhyolite that displays varied but generally steep (and locally internally contorted) flow foliation. Flow-laminated rhyolite forms most of the southeastern part of the fissure-vent complex in the study area. North of the study area, flow-laminated rhyolite is scarce and the fissure-vent complex consists almost entirely of pyroclastic rhyolite. Both textural variants of the fissurevent complex rhyolite intrude older ash-flow tuff units, and locally they may intrude pre-Tertiary gabbro and diorite. Black-green to gray vitrophyre is locally present along the 
margin of the fissure-vent-complex rocks. Silicified breccia and volcaniclastic conglomeratic rocks are locally present at the contact with the pre-Tertiary gabbro and diorite. Crosscutting millimeter-scale quartz veinlets and casts of weathered pyrite(?) cubes in the flow-laminated rhyolite indicate that the fissure-vent-complex rhyolite has been hydrothermally altered. The ash-flow tuff/fissure-vent complex has not been radiometrically dated, but cross-cutting relationships indicate that it is younger than the basal tuff and tuffs A and B. It is older than the hypabyssal dacite that intrudes rocks of the fissure-vent complex. The age relationship between the fissure-vent-complex rhyolite and the tuff of Toiyabe is not constrained by field relations.

Hypabyssal dacite (Td).-Greenish-gray- and brownweathering porphyritic dacite forms extensive outcrops on the east flank of the Terrill Mountains (fig. 2). These exposures form stock-like intrusions a few square kilometers in area and dike, sill, and plug-like intrusions 2-200 m thick. The hypabyssal dacite consists predominantly of mediumand coarse-grained, porphyritic, biotite-hornblende-bearing dacite, but, in one stock in the western part of the study area, hornblende-rich dacite grades into hornblende-poor, biotiterich, medium-grained, equigranular rhyodacite. A sample of the hypabyssal dacite collected near the range front about 1.5 $\mathrm{km}$ northwest of Camp Terrill yielded a K-Ar date of 21.8 Ma (Silberman and McKee, 1972, recalculated). This unit intrudes all the ash-flow tuff units exposed in the east flank of the Terrill Mountains, as well as rocks of the ash-flow tuff fissure-vent complex.

Andesite lavas and lahars (Tal).-Medium-gray, hornblende-andesite lahars and minor interbedded lenses of fluvial epiclastic sedimentary rocks form this unit, which unconformably overlies the ash-flow tuff units exposed on the east flank of the Terrill Mountains. This unit also caps the crest and much of the western slope of the range. Locally, in the study area and to the northwest in the northern part of the range, plagioclase-andesite porphyry lavas underlie the hornblende-andesite lahars and unconformably overlie the sequence of ash-flow tuffs. The hornblende-andesite lahars characteristically form rubbly weathering outcrops of cobble, boulder, and occasional block size, rounded to subrounded clasts of hornblende-andesite in a coarse-grained clastic matrix. The exposed thickness of these rocks is about $180 \mathrm{~m}$, and they dip southwesterly at about $15^{\circ}-20^{\circ}$. The andesite lavas and lahars unit in the Terrill Mountains has not been dated, but it is correlated with lithologically and texturally identical hornblende-andesite lahars to the east, in the Barnett Hills and southern Cocoon Mountains, where a $\mathrm{K}$-Ar date of $18.1 \mathrm{Ma}$ was determined on hornblende (Silberman and McKee, 1972, recalculated).

\section{STRUCTURE}

The Terrill Mountains are a fault-bounded structural block within the zone of northwest-trending strike-slip faults of the central Walker Lane (Hardyman and Oldow, 1991; Hardyman and others, 1992). The main structural features in the Terrill Mountains are northwest-trending high-angle strike-slip faults, low-angle faults, and north- to north-northeast-trending high-angle faults.

Northwest-trending high-angle faults. - The Tertiary volcanic rocks in the Terrill Mountains structural block are locally disrupted by high-angle faults that strike N. $40^{\circ} \mathrm{W}$. The northwest-trending high-angle faults are Walker Lanestyle strike-slip faults and have exposed strike lengths of 1-2 km (fig. 1). They are locally intruded and truncated by the hypabyssal dacite unit. Elongation of several dacite intrusive bodies and of the ash-flow tuff/fissure-vent complex suggests that emplacement of these intrusive units was controlled by northwest-striking structures that predate the 21.8Ma dacite intrusions. Post-intrusion movement on some faults is indicated by slickensided fault surfaces on dacite dike margins and may indicate reactivation of some faults. Scarps in older alluvium occur along the trace of one of the high-angle strike-slip faults that bounds the range front southeast of Camp Terrill and extends beyond the study area. These scarps cut an alluvial surface of probable Pliocene age. Geomorphic evidence along this strike-slip fault indicates that fault movement produced significant right-lateral slip.

Low-angle faults. - The ash-flow tuff units in the Terrill Mountains are locally decoupled from the pre-Tertiary basement rocks along a nearly flat detachment fault. At least two other major low-angle $\left(<10^{\circ}\right.$ to $\left.15^{\circ}\right)$ detachment faults occur within the ash-flow-tuff stratigraphic section (figs. 2 and 3). One of these, the Camp Terrill fault (Hardyman and others, 1992), formed at about $22 \mathrm{Ma}$, after deposition of the tuff of Toiyabe (23-22 $\mathrm{Ma}$ ) and prior to emplacement of the hypabyssal dacite (Td) (21.8 Ma). The Camp Terrill fault is cut by three northwest-striking high-angle faults, one of which has down-dropped the Camp Terrill fault and its upper plate about $200-250 \mathrm{~m}$ to the northeast. The fault is $0.5-$ to 2-m wide and contains phyllonitic gouge and crushed rock that has been hydrothermally altered. The amount of lateral offset, if any, on these northwest-striking high-angle faults is unknown. The high-angle fault and the Camp Terrill detachment faults both are intruded by hypabyssal dacite (Td). The tuff of Toiyabe in the upper plate of the Camp Terrill fault generally dips $35^{\circ}-45^{\circ}$ east, except in a central panel of the fault where it dips $10^{\circ}-20^{\circ}$ west. A separate detachment fault, here termed the Waterfall fault, lies below (ash-flow) tuff $\mathrm{B}$ (figs. 2 and 3); the upper plate of this fault dips $15^{\circ}-20^{\circ}$ west and is subparallel to the basal detachment fault. The Waterfall fault dips north and west in a bowl-like shape, has several anastomosing splays, contains a 0.5- to 1$\mathrm{m}$-thick gouge zone, and is locally filled with pods of mafic volcanic rocks. These features are accompanied by $50-100$ $\mathrm{m}$ of argillic alteration and bleaching that have affected wallrocks 5-100 m outward from the fault. The low-angle fault that dips $10^{\circ}$ west beneath (ash-flow) tuff Tta is approximately $1 \mathrm{~m}$ wide and contains brecciated, hematitic, milky quartz. 


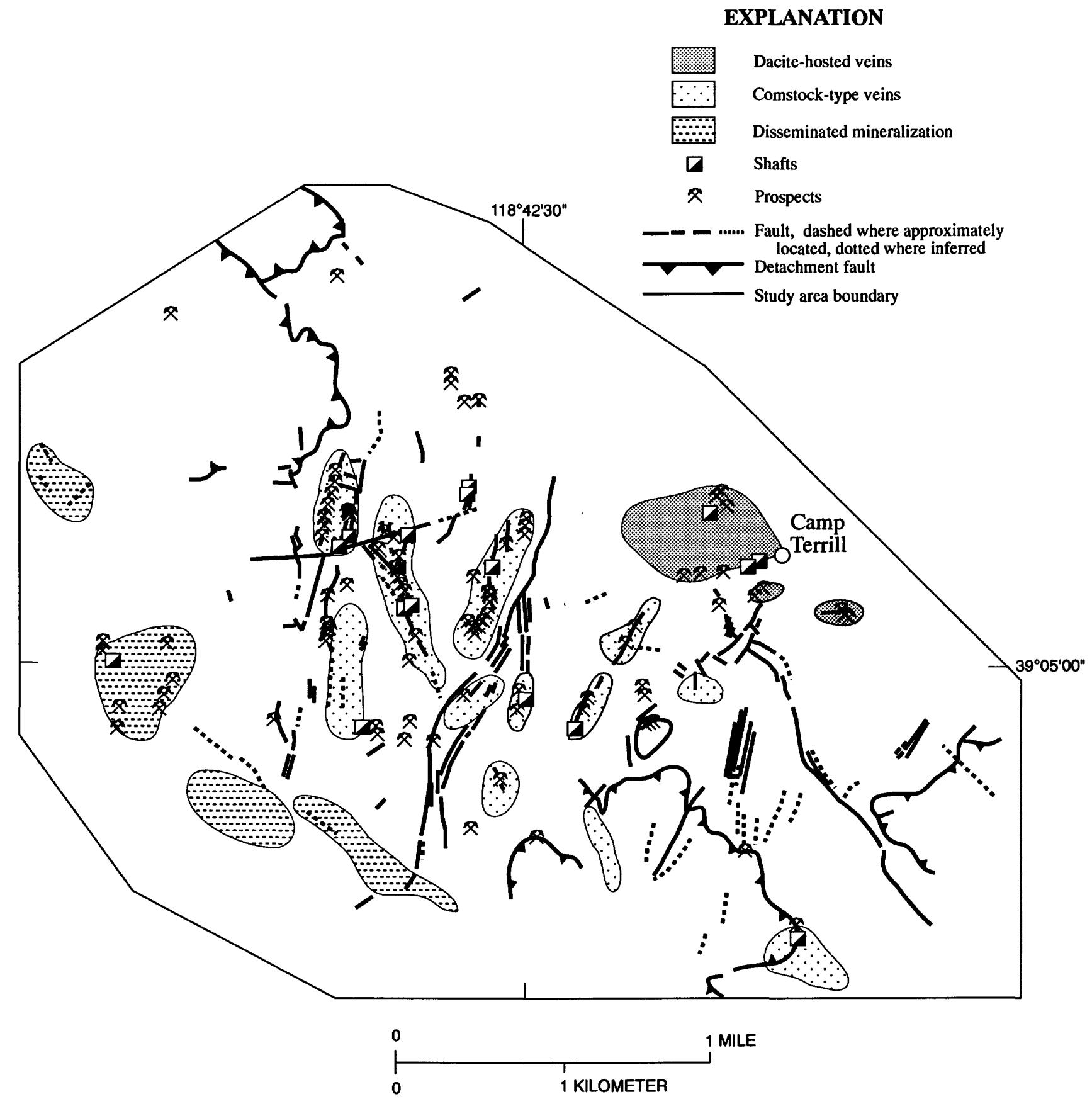

Figure 3. Mineralized areas in the Terrill Mountains portrayed with major faults, prospects, and mines. Each shaded area represents an area of altered rocks, mineral deposits and prospecting, or mining activity.

High-angle northeast-trending faults. - Vertical faults, averaging $\mathrm{N} .20^{\circ} \mathrm{E}$. in strike form several composite systems in the study area. Two main fault systems occur in the central part of the study area (fig. 3). They are the structures that predominantly controlled the flow of hydrothermal solutions in the Terrill Mountains. These faults are commonly 0.5- to 1-m wide and contain extensive gouge, crushed rock, and clay seams. Dips are both west and east, but they are seldom less than $60^{\circ}$. Offset in plan view, interpreted from tuff stratigraphy, may have been as much as $600 \mathrm{~m}$ sinistrally.

Compaction foliation.-Compaction foliation varies throughout the study area, but predominant attitudes are $10^{\circ}-20^{\circ}$ west, particularly in the basal tuff, (ash-flow) tuff B (Ttb), and central occurrences of the tuff of Toiyabe (fig. 2). A central part of the basal tuff and tuffs in the southeast, which are separated by a northwest-striking fault, both dip 
east. These distinct areas of east-dipping compaction foliation define two 1 - by 0.5 -km-long blocks that have been rotated separately by complex, high-angle and low-angle fault movement and hypabyssal dacite intrusion. Moderately steep tilts of the tuff of Toiyabe above the Camp Terrill fault were interpreted by Hardyman and others (1992) to be due to closely spaced domino-style normal faults (not shown on fig. 2) and block rotation associated with the formation of the Camp Terrill detachment fault.

\section{MINERAL DEPOSITS}

Base and precious metals in the Terrill Mountains have been mined from oxidized and unoxidized zones of veins contained within the fault zones. The oxidized veins have been mined mostly for silver and manganese in vertical northeast-striking veins in hypabyssal dacite at the range front near Camp Terrill (fig. 3). At higher elevations on the east flank of the range, both oxidized and unoxidized ore zones in ash-flow tuff were mined for silver and gold (fig. 3). In addition, gold and silver were mined from veins in some flat-lying faults in the upper Camp Terrill fault and in veins within broad altered areas in and near the hypabyssal dacite in the west (fig. 3).

Minerals found in oxidized ores include cerargyrite, cerussite, gold, rhodochrosite, psilomelane, and pyrolusite. Minerals in unoxidized ores are sphalerite, tetrahedrite, chalcopyrite, galena, argentite, arsenopyrite, pyrite, native silver, and electrum. Veins range from $1 \mathrm{~cm}$ to $1 \mathrm{~m}$ in width and contain plunging oreshoots approximately 25 by $100 \mathrm{~m}$ in size. Oxide ore grades of vein material are typically 200 to $20,000 \mathrm{~g} / \mathrm{t}$ silver and 5 to 10 percent manganese; the veins locally yield gold and lead ores. Ore grades of unoxidized vein material are typically 8 to $16 \mathrm{~g} / \mathrm{t}$ silver, 7 to $50 \mathrm{~g} / \mathrm{t}$ gold, 8 to 11 percent lead, and 13 to 17 percent zinc. Veins and oreshoots are most common in the tuffs at the faulted margins of dikes or along the contacts of stocks, plugs, and apophyses of the hypabyssal dacite. There is a distinct spatial association of mineralized rock and hypabyssal dacite intrusive bodies; however, there is no evidence to support a direct genetic relationship between mineralization and the emplacement of the hypabyssal dacite.

Preliminary geochemical studies of mineralized samples from the Terrill Mountains demonstrate a consistent ratio of gold to silver, suggesting possible deposition of both these elements from a single hydrothermal system. The ratio of gold to silver in mineralized rock samples taken throughout the Terrill Mountains is about 1:100 (fig. 4). This constant ratio suggests that the mineralizing system was generated from a single source and that it could have involved a single hydrothermal solution and process. If a single process was involved, local populations of samples with higher or lower gold-silver ratios could have resulted from supergene processes (fig. 4). In addition, a significant

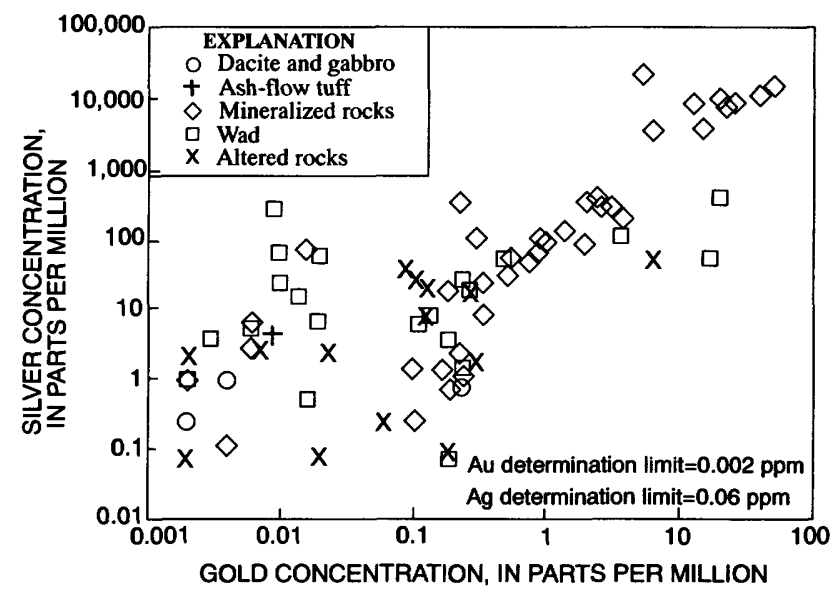

Figure 4. Plot of gold versus silver from rock samples collected as part of this study. The samples represent grab and channel samples of mineralized rock in and around the veins, faults, and altered rock areas in the Terrill Mountains. Gold was determined by standard graphite-furnace analysis; silver was determined was by optical spectroscopy. Chemical analyses conducted by P.H. Briggs, J.M. Motooka, B.M. Adrian, P.L. Hageman, D.M. Hopkins, D.L. Fey, A.H. Love, and L.A. Bradley.

number of samples have gold and silver values of 0.5 to $3 \mathrm{~g} / \mathrm{t}$, which may indicate that these metals are disseminated through a large volume of rock in the area. This suggests that a mineralization event may have taken place in addition to that which formed the high-grade veins.

Alteration proximal to the veins commonly consists of sericite-adularia-quartz (and only locally carbonate minerals). Pyrophyllite is present locally as an alteration mineral in mineralized zones along some shallow-dipping faults. These minerals typically replaced the groundmass and feldspar phenocrysts in hypabyssal dacite without destroying the rock texture. Alteration in the tuffs was more pervasive, and, in some areas, wallrock alteration widened a vein width outward from the center of the host fissure. This relation suggests that fluid flow was focused along faults and fractures and rarely invaded the surrounding rock. Pervasive mineralization that occurred along highly permeable epiclastic sedimentary rock horizons between ash-flow-tuff cooling units, usually but not always adjacent to the main mineralized faults, is a striking exception.

Broad, pervasively altered areas in the western hypabyssal dacite (fig. 3), contain alteration assemblages of kaolinite, illite, quartz, and albite. These alteration zones are distinct in size, style, and mineralogy compared to the sericite-quartz-adularia alteration envelopes around veins to the east, and these alteration zones occur in four, large, northwesterly elongated areas in the western part of the study area (fig. 3). Porosity and permeability appear to have been high in these areas. These altered areas may represent a younger mineralizing event because, locally, the adjacent hornblende-andesite $(18.1 \mathrm{Ma})$ is altered. 
The silver-gold veins and associated altered rocks are similar to Comstock-type veins and associated altered rocks described by Cox and Singer (1986). Distribution of the mineral deposits, uniformity in their gold to silver ratios, and similarity of associated altered rocks suggest that a hydrothermal system of the Comstock type was active over at least a $16-\mathrm{km}^{2}$ area in the Terrill Mountains. The zones of broad, pervasive, hypabyssal-dacite-hosted altered rocks can be interpreted to represent distinct mineralization that represents either a different level of a single hydrothermal system or, possibly, a separate younger event.

\section{CONCLUSIONS}

The Terrill Mountains area of the Holy Cross mining district contains Comstock-type silver-gold veins that, for the most part, are hosted in fault-hosted veins. Northwestand north-northeast-striking high-angle faults within the Terrill Mountains structural block were the predominant conduits for flow of hydrothermal fluids. Low-angle detachment faults locally trapped hydrothermal fluids where adjacent to, or above, high-angle fault conduits. Field relationships suggest that most of the faulting occurred within a short time frame, linked perhaps to one major tectonic event. Mineralization was limited to specific lithologic units in a discrete area, probably because of structural constraints on fluid flow and a focused source of hydrothermal fluids.

Although not precisely constrained, the age of mineralization and alteration in the Terrill Mountains area must postdate the 21.8-Ma intrusive hypabyssal dacite, with which it is associated spatially, but it must predate unaltered, unmineralized 18.1-Ma hornblende-andesite lahars that cap the Terrill Mountains. These constraints suggest that the age of silver-gold mineralization in the Terrill Mountains is essentially the same (about $19 \mathrm{Ma}$ ) as that of precious metal deposits farther to the southeast, in the central Walker Lane (for example at Paradise Peak, and the Santa Fe district), where structural settings are similar. However, it appears that the age of mineralization in the Terrill Mountains is older than mineralization at Rawhide (15-16 Ma), which is the nearest significant precious metal deposit. A possible exception to this is mineralization associated with pervasive alteration in the west part of the Terrill Mountains, which postdates the 18.1-Ma hornblende-andesite lahars.

\section{REFERENCES CITED}

Bingler, E.C., 1978, Geologic map of the Schurz quadrangle: Nevada Bureau of Mines and Geology, Map 60, $1 \mathrm{pl}$.

Black, J.E., Mancuso, T.K., and Gant, J.L., 1991, Geology and mineralization at the Rawhide $\mathrm{Au}-\mathrm{Ag}$ deposit, Mineral County, Nevada, in Raines, G.L., Lisle, R.F., Schaefer, R.W., and Wilkinson, W.H., eds., Geology and Ore Deposits of the Great
Basin: Reno, Nevada, Geological Society of Nevada, Symposium Proceedings, v. 2, p. 1123-1144.

Bremm, G.F., Purdy, T.L., and Snyder, D.B., 1985, Oligocene and Miocene volcanic-tectonic history of the southern Toiyabe and Shoshone Mountains [abs.]: Geological Society of America Abstracts with Programs, v. 17, p. 343.

Bremm, G.F., John, D.A., Nash, J.T., Poole, F.G., and Snyder, D.B., 1991, Mineral resources of the Arc Dome Wilderness Recommendation Area, Nye County, Nevada: U.S. Geological Survey Bulletin 1961, $21 \mathrm{p}$.

Cox, D.P., and Singer, D.A., 1986, Mineral deposit models: U.S. Geological Survey Bulletin 1693, 379 p.

Dilles, J.H., John, D.A., and Hardyman, R.F., 1993, Evolution of Cenozoic magmatism and tectonism along a northeast-southwest transect across the northern Walker Lane, west-central Nevada-Part I, in Lahren, M.M., Trexler, Jr., J.H., and Spinosa, C., eds., Crustal Evolution of the Great Basin and the Sierra Nevada: Reno, Nevada, Department of Geological Sciences, Mackay School of Mines, University of Nevada, Reno, Geological Society of America Field Trip Guidebook, Cordilleran/Rocky Mountain Section meeting, p. 409-428.

Hardyman, R.F., 1980, Geological map of the Gillis Canyon quadrangle, Mineral County, Nevada: U.S. Geological Survey Miscellaneous Investigations Series Map I-1237, scale 1:48,000.

Hardyman, R.F., McKee, E.H., Snee, L.W., and Whitebread, D.H., 1992, The Camp Terrill and Dicalite Summit faults-Two contrasting examples of detachment faults in the central Walker Lane, Western Nevada, in Craig, S.D., ed., Geological Society of Nevada, Proceedings Volume, Walker Lane Symposium, p. 93-113.

Hardyman, R.F., and Oldow, J.S., 1991, Tertiary tectonic framework and Cenozoic history of the central Walker Lane, Nevada, in Raines, G.L., Lisle, R.F., Schafer, R.W., and Wilkinson, W.H., eds., Geology and Ore Deposits of the Great Basin: Reno, Nevada, Geological Society of Nevada, Symposium Proceedings, v. 1, p. 279-301.

Lincoln, F.C., 1923, Mining Districts and Mineral Resources of Nevada: Reno, Nevada, Nevada Newsletter Publishing Company, $295 \mathrm{p}$.

Oldow, J.S., Bally, A.W., Ave 'Lallemant, H.G., and Leeman, W.P., 1989, Phanerozoic evolution of the North American Cordillera-United States and Canada, in Bally, A.W., and Palmer, A.R., eds, The Geology of North America-An Overview: Boulder, Colorado, Geological Society of America, v. A, p. 139-232.

Ross, D.C., 1961, Geology and mineral deposits of Mineral County, Nevada: Nevada Bureau of Mines and Geology Bulletin 58, $98 \mathrm{p}$.

Schraeder, F.C., 1947, Carson Sink area, Nevada: U.S. Geological Survey Open-File Report, 15 p.

Silberman, M.L., and McKee, E.H., 1972, A summary of radiometric age determinations on Tertiary volcanic rocks from Nevada and eastern California-Part II, western Nevada: Isochron/ West, no. 4, p. 7-28.

Vanderburg, W.O., 1940, Reconnaissance of mining districts in Churchill County, Nevada: United States Bureau Mines, Information Circular 7093, p. 30-37.

Willen, R., and Speed, R.C., 1974, Geology and mineral deposits of Churchill County, Nevada: Nevada Bureau of Mines and Geology Bulletin 83, 95 p. 


\title{
TIME-pH- $\mathrm{f}_{2}$ PATHS OF HYDROTHERMAL FLUIDS AND THE ORIGIN OF QUARTZ-ALUNITE-GOLD DEPOSITS
}

\author{
By George V. Albino ${ }^{1}$
}

\begin{abstract}
Quartz-alunite-gold, massive enargite-pyrite, and porphyry copper-gold deposits constitute a related group of deposits associated with magmatic-hydrothermal systems. Alteration assemblages in porphyry deposits indicate mineralization by near-neutral fluids with elevated $\mathrm{f}_{\mathrm{O}_{2}}$ (fugacity of oxygen) and low $\mathrm{f}_{\mathrm{S}_{2}}$ (fugacity of sulfur); those in enargitepyrite deposits show elevated $\mathrm{f}_{\mathrm{O}_{2}}$ and $\mathrm{f}_{\mathrm{S}_{2}}$ associated with very low $\mathrm{pH}$; whereas gold-alunite-pyrite deposits were deposited from fluids with moderate $\mathrm{pH}, \mathrm{f}_{\mathrm{S}_{2}}$, and $\mathrm{f}_{\mathrm{O}_{2}}$. Copper-to-gold ratios and silver-to-gold ratios have similar ranges in porphyry and enargite-pyrite, whereas quartzalunite-gold deposits have much higher gold contents relative to other metals. Where several deposit types are found together, they apparently formed in the order porphyry copper, enargite-pyrite, quartz-alunite-gold. Spatial relations mimic temporal ones, with porphyry deposits formed deepest and quartz-alunite-gold deposits shallowest.

Time relations between different deposit types, combined with the progression of ore-fluid compositions, are consistent with high-grade quartz-alunite-gold deposits having formed by remobilization of gold, in the form of a bisulfide complex, from earlier formed copper-gold mineralization in which both copper and gold were transported as chloride complexes. The near-neutral, relatively reduced fluids responsible for deposition of the high-grade gold ores may have formed as a result of incorporation of meteoric or formation waters into a previously magmaticwater-dominated hydrothermal system.
\end{abstract}

\section{INTRODUCTION}

Temporal and spatial variations in compositions of oreforming fluids have been documented by many workers

\footnotetext{
${ }^{1}$ U.S. Geological Survey Mission, Unit 62101, APO AE 09811-2101.
}

from a variety of different types of ore deposits (Gustafson and Hunt, 1975; Bartos, 1989; Large and others, 1989). The formation of alteration and vein assemblages indicative of fluids with low $\mathrm{pH}$ and elevated $\mathrm{f}_{\mathrm{O}_{2}}$ and (or) $\mathrm{f}_{\mathrm{S}_{2}}$ is a common feature in a variety of precious- and base-metal ores. These include deposits considered to be epithermal (Ashley, 1990; John and others, 1989) as well as those inferred to have formed at relatively high temperatures (Sillitoe, 1983; Brimhall, 1980). In many cases, alteration by acid fluids occurs late in the history of hydrothermal activity (Gustafson and Hunt, 1975), whereas, in others, acid and oxidized fluids have been succeeded by those with higher $\mathrm{pH}$ and lower oxidation state (Beane and others, 1991). The origin of these acid fluids is a matter of debate, with a strong component of direct magmatic addition likely in at least some deposits. In a recent paper, Bartos (1989) proposed that two distinct evolutionary paths can be defined for magmatic-hydrothermal systems. In his terminology, where fluid $\mathrm{pH}$ decreases, and $\mathrm{f}_{\mathrm{O}_{2}}$ and $\mathrm{f}_{\mathrm{S}_{2}}$ increase with time, the system is said to follow a "prograding" path. For the opposite situation, in which later fluids are less acid and have lower $f_{\mathrm{O}_{2}}$ and $\mathrm{f}_{\mathrm{S}_{2}}$, the evolution is defined as "retrograde." Note that this usage differs from that of Hemley and Hunt (1992), who use "prograde" and "retrograde" principally in a thermal sense. Bartos was concerned mainly with base-metal-enriched deposits, but the same ideas may have important implications in discussions of genesis of gold-silver deposits. This is true especially for acid-sulfate (Heald and others, 1987) or high-sulfur-type (Bonham, 1988) deposits, mainly enargite-bearing coppergold deposits, such as Goldfield (Ransome, 1909; Ashley, 1974, 1990; Tolman and Ambrose, 1934) or El Indio (Siddeley and Araneda, 1986; Jannas and others, 1990). Processes controlling formation of silver- and lead-rich acid-sulfate type deposits, such as Paradise Peak, Nevada (John and others, 1989), or La Coipa, Chile (Oviedo and others, 1991), may be different.

In this paper I would like to suggest that high-grade quartz-alunite-gold vein deposits form late in the 
Table 1. Districts containing Au-alunite veins and Au-rich, massive, enargite-pyrite deposits.

[M, million, $\mathbf{K}$, thousand]

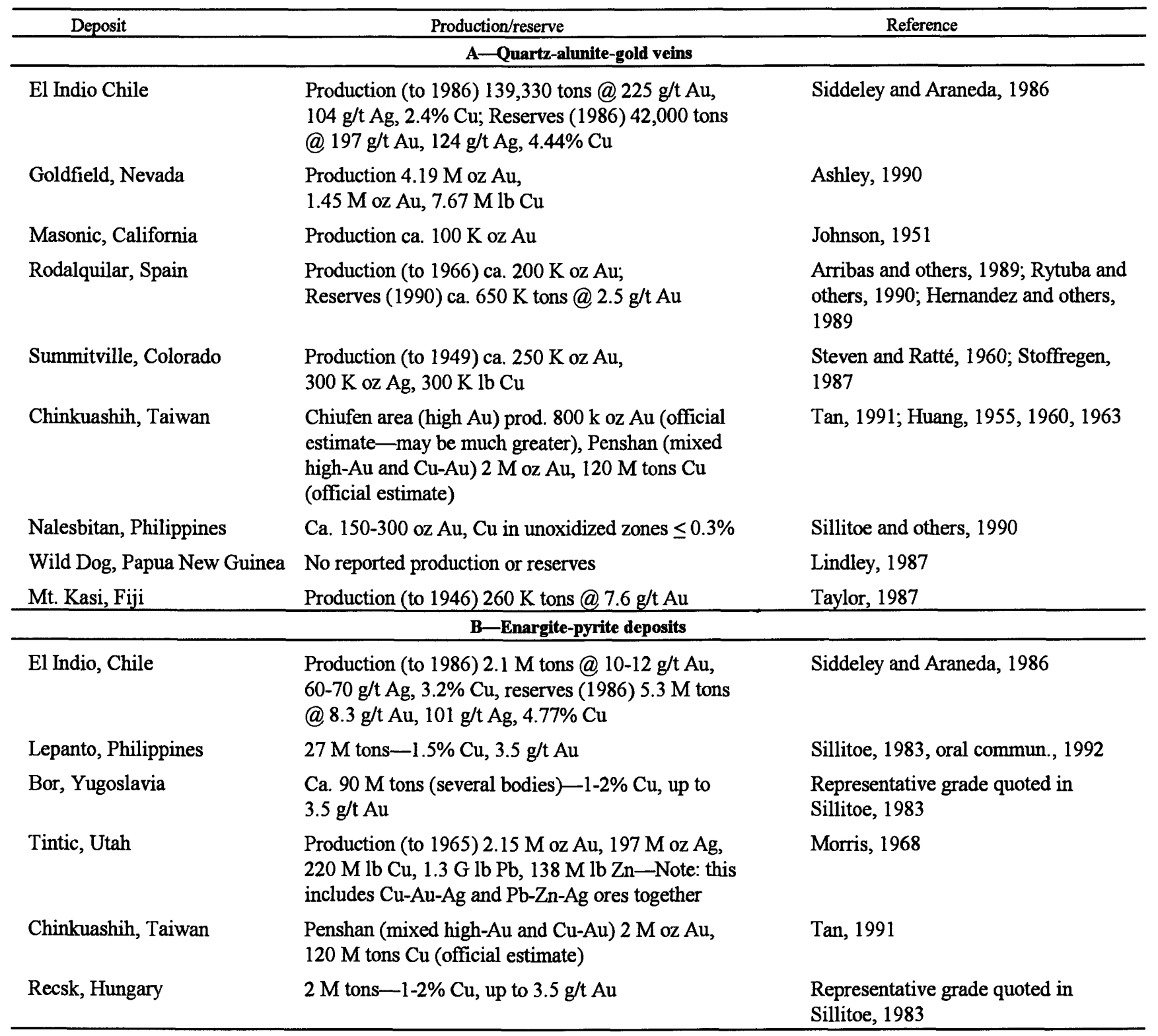

mineralization history of a pluton-centered hydrothermal system, under conditions of moderate $\mathrm{pH}, \mathrm{f}_{\mathrm{O}_{2}}$, and $\mathrm{f}_{\mathrm{S}_{2}}$, following a period of acid leaching (i.e., they are "retrograde" in Bartos' (1989) terminology). The association of high-grade gold with these assemblages is a consequence of the high solubility of gold (as compared to copper) as gold-bisulfide complexes in moderately reduced, near-neutral solutions, which can result in large-scale remobilization of gold from previously formed copper-gold mineralization. Note that the two-stage process proposed below for pluton-related deposits is very similar to that documented by Large and others (1989) for the formation of late-stage, gold-enriched zones in volcanogenic massive sulfide deposits.

\section{QUARTZ-ALUNITE-GOLD DEPOSITS}

\section{GENERAL CHARACTERISTICS}

Quartz-alunite-gold (copper-silver) veins constitute a distinct class of ore deposits (Berger, 1986). Although relatively few deposits of this type are known, they have been important sources of gold production from a number of districts (table 1). They occur in some districts with temporally and spatially related massive enargite-pyrite mineralization of the type described below (El Indio, Chile--Siddeley and Araneda, 1986; Chinkuashih, Taiwan-Tan, 1991), and, in other districts, they occur without such associated deposits 
(Masonic district, California-Johnson, 1951). In some areas (Steven and Ratté, 1960), deeper porphyry-style mineralization has been reported.

The characteristics of these deposits are somewhat variable, but important features in common include their association with mainly andesite, dacite, or quartz-latite tuffs, flows, and minor intrusions (Ashley and Silberman, 1976; Rytuba and others, 1989, 1990; Siddeley and Araneda, 1986; Tan, 1991; Johnson, 1951). In all districts, there are large volumes (at least several cubic kilometers) of rocks that have been intensely altered to clays, quartz, and typically abundant alunite (Arribas and others, 1989; Johnson, 1951; Ashley, 1990). Within these large altered areas are small bodies of extremely high grade gold ores. In districts where copperpredominant deposits occur with quartz-alunite-gold veins, the gold-predominant deposits invariably formed later than the copper-rich deposits (Siddeley and Araneda, 1986; Jannas and others, 1990) and tend to occur above and (or) peripheral to the center of the copper-gold mineralization (Jannas and others, 1990; Arribas and others, 1989; Huang and Yeh, 1977). Early-formed low-grade disseminated gold mineralization (accompanied by copper sulfides) is reported in some districts (Stoffregen, 1987; Tan, 1991).

A further style of gold mineralization accompanying some quartz-alunite-gold deposits is typified by the El Tambo deposit, located approximately $5 \mathrm{~km}$ from El Indio, Chile (Siddeley and Araneda, 1986). Here, gold occurs mainly associated with largely sulfide-free barite-alunite veins that contain jarosite, interpreted as primary in origin (Beane and others, 1991). Apparently this style of mineralization lies above and in sharp contact with deeper enargitebearing veins. Similar very oxidized gold mineralization has also been described from Summitville (Stoffregen, 1987) and Goldfield (Keith and others, 1980; R.P. Ashley, oral commun., 1992).

\section{METAL CONTENT OF QUARTZ-ALUNITE-GOLD VEINS}

Metal ratios in high-grade gold ores are distinct from those in related deposit types, such as porphyry copper and massive enargite-pyrite veins. They are characterized by low $\mathrm{Ag}$-to-Au ratios, typically less than 1 (table 1 , part $\mathrm{A}$ ), and $\mathrm{Cu}$-to-Au ratios commonly between $10^{3}$ and $10^{2}$, and locally lower (see, for example, Johnson, 1951; Siddeley and Araneda, 1986; Vikre, 1989; Mosier and Menzie, 1986).

\section{INTRUSION-RELATED COPPER-GOLD DEPOSITS}

\section{GENERAL CHARACTERISTICS}

Gold and copper occur together in a suite of genetically related deposit types that includes porphyry copper-gold

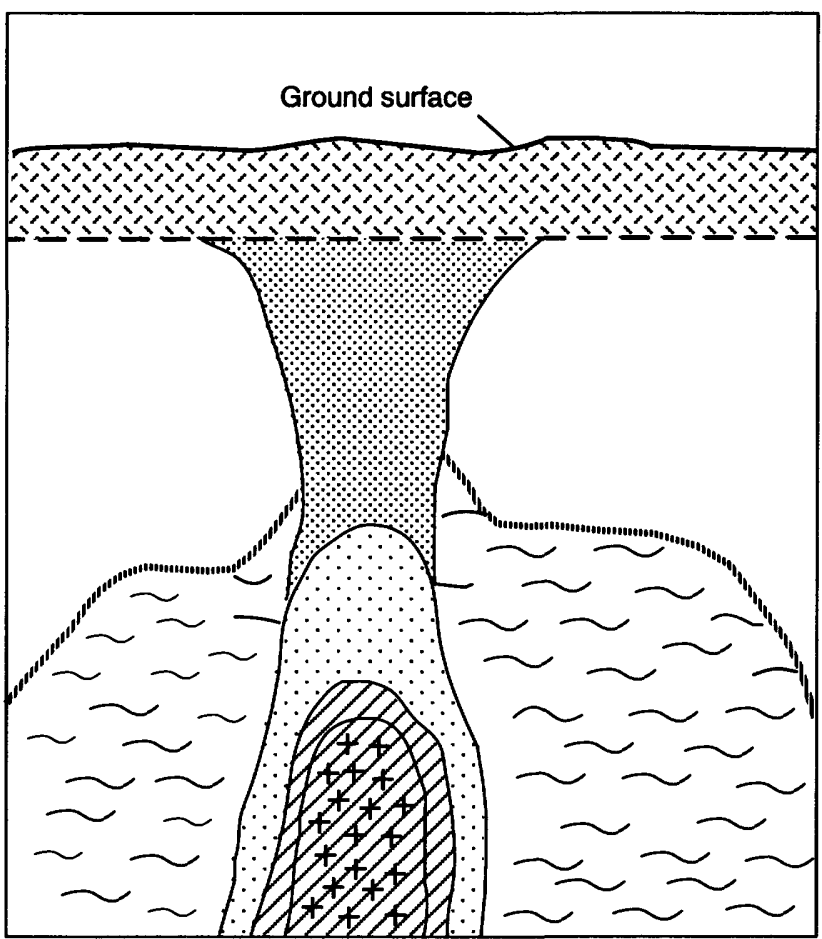

\section{EXPLANATION}

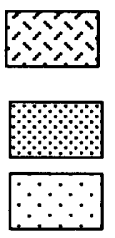

Opal-cristobalite-

Advanced argillic

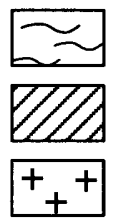

Propylitic

Potassic

Phyllic

Igneous intrusion

Figure 1. Generalized cross-section showing alteration zones developed in association with porphyry copper emplacement. Mineral assemblages characteristic of alteration zones are given in table 2. Modified from Lowell and Guilbert (1970), Gustafson and Hunt (1975), Sillitoe (1973).

deposits, and massive enargite-pyrite veins and replacements, in addition to the high-grade enargite- or tennantitebearing quartz-alunite-gold veins described above (Sillitoe, $1988,1989)$. In porphyry deposits there is a well-documented spatial pattern of alteration and ore and gangue minerals (fig. 1, table 2), in which deeper and more central zones have assemblages indicative of neutral to alkaline fluids with low $\mathrm{f}_{\mathrm{S}_{2}}$ and relatively high $\mathrm{f}_{\mathrm{O}_{2}}$ (Rose and Burt, 1979; Beane and Titley, 1981). Peripheral to many porphyry deposits, and particularly at high levels, alteration and ore-mineral assemblages indicate that mineralizing fluids had higher $\mathrm{H}^{+}$activities and $\mathrm{f}_{\mathrm{S}_{2}}$ (Gustafson and Hunt, 1975; Meyer and Hemley, 1967). These conditions are indicated by phyllic, argillic, and advanced argillic zones (Meyer and Hemley, 1967). In the latter, copper sulfosalts are common, particularly those 
Table 2. Alteration zones and assemblages in porphyry copper deposits.

[Zone names after Lowell and Guilbert, 1970. Data from Lowell and Gnilbert, 1970; Beane, 1982; Beane and Titley, 1981; Sillitoe, 1990]

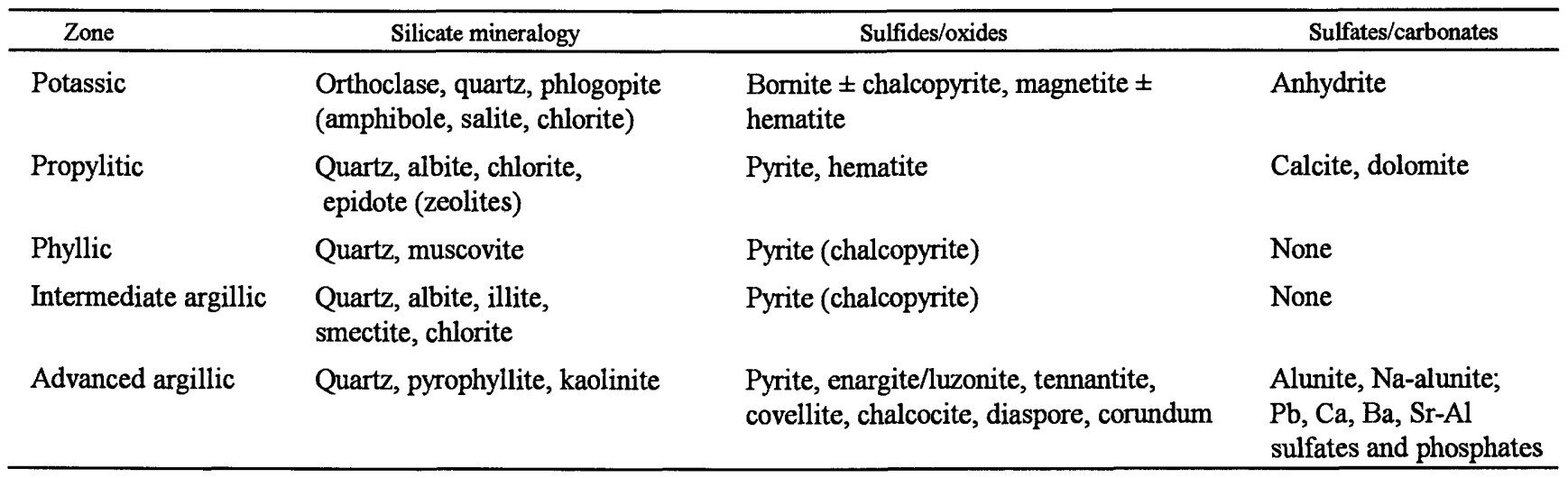

Table 3. Comparative characteristics of different magmatic-related $\mathrm{Cu}-\mathrm{Au}$ deposits.

[Mod, moderate; $f_{\mathrm{O}_{2}}$, fugacity of oxygen; $f_{S_{2}}$, fugacity of sulfur]

\begin{tabular}{llll}
\hline & \multicolumn{1}{c}{ Porphyry copper deposits } & \multicolumn{1}{c}{ Massive enargite-pyrite deposits } & \multicolumn{1}{c}{ Quartz-alunite-gold veins } \\
\hline Alteration & K-feldspar, phlogopite, anhydrite & $\begin{array}{l}\text { Quartz, alunite, dickite/kaolinite, } \\
\text { diaspore, pyrophyllite }\end{array}$ & Kaolinite, sericite, pyrophyllite \\
Opaque mineralogy & $\begin{array}{l}\text { Bornite-chalcopyrite-magnetite } \\
( \pm \text { hematite })\end{array}$ & $\begin{array}{l}\text { Enargite, covellite, chalcocite, } \\
\text { pyrite }\end{array}$ & $\begin{array}{l}\text { Tennantite, chalcopyrite, pyrite, } \\
\text { sphalerite }\end{array}$ \\
$\mathrm{Cu} / \mathrm{Au}$ & $10^{4}$ to $>10^{5}$ & $10^{3.5}-10^{5}$ & $\leq 10^{2}: 1$ \\
$\mathrm{Ag} / \mathrm{Au}$ & $5: 1$ to $20: 1$ & $5: 1$ to $20: 1$ & $<1: 1$ \\
$\mathrm{pH}$ & Alkaline/neutral & Very acid & Acid to near neutral \\
Fugacities & Mod/high $\mathrm{f}_{\mathrm{O}_{2}} ;$ low/very low $\mathrm{f}_{\mathrm{S}_{2}}$ & Very high $\mathrm{f}_{\mathrm{S}_{2}} / \mathrm{f}_{\mathrm{O}_{2}}$ & Moderate to high $\mathrm{f}_{\mathrm{O}_{2}} / \mathrm{f}_{\mathrm{S}_{2}}$ \\
Examples & Grasberg, Irian Jaya; & Lepanto, Philippines; & Goldfield, Nevada; \\
& Bingham, Utah & El Indio, Chile & El Indio, Chile \\
\hline
\end{tabular}

belonging to the enargite-luzonite and tennantite-tetrahedrite solid solutions. These phases, as well as assemblages where the copper sulfides chalcocite and covellite coexist with pyrite, indicate crystallization at elevated $\mathrm{f}_{\mathrm{S}_{2}}$ (Barton and Skinner, 1979). These sulfur-rich ore-mineral assemblages may occur either as widespread disseminations or veinlet fillings in the lithocap above porphyry copper deposits (Corn, 1975; Bodnar and Beane, 1980), or, in some instances (Sillitoe, 1983), they form massive fracture and replacement enargite-pyrite deposits (table 3). A number of these deposits with high-sulfidation mineral assemblages have been important sources of gold as well as copper (table 1, part B). These deposits, in general, are accompanied by abundant primary hypogene alunite, indicating low $\mathrm{pH}$ and high $\mathrm{f}_{\mathrm{O}_{2}}$ in addition to a high sulfidation state. The near-magmatic values of $\delta^{34} \mathrm{~S}$ seen in massive alunite interbanded with enargite at $\mathrm{El}$ Indio
(Jannas and others, 1990) suggest that nearly quantitative oxidation of magmatic sulfur may occur episodically in these systems under hypogene conditions.

\section{METAL CONTENTS OF COPPER-GOLD DEPOSITS}

The range of $\mathrm{Cu}: \mathrm{Au}$ in porphyry deposits (Cox and Singer, 1988; Sillitoe, 1990) is from approximately $10^{6}$ to $10^{4}$ (the latter corresponds to $1 \mathrm{~g} / \mathrm{t}$ gold at a copper grade of 1 percent). In massive enargite deposits, the range is similar (Morris, 1968; Siddeley and Araneda, 1986; Sillitoe, 1983), although more deposits may be somewhat gold rich (Sillitoe, 1983) (table 3). Silver-to-gold ratio data are not available for some districts (for example, deep copper-sulfide-rich ores at Goldfield), but this ratio is apparently typically in excess of 
10:1 (table 3). Note that these ratios are quite similar to those estimated for the crust as a whole and for common igneous rocks (Krauskopf, 1979).

\section{PARAGENETIC RELATIONSHIPS BETWEEN QUARTZ-ALUNITE-GOLD AND ASSOCIATED COPPER-GOLD DEPOSITS}

Changes in mineral assemblages with time are reported in well-studied deposits. At El Indio, for example, copperstage veins contain enargite, whereas later transitional and gold-stage veins contain tennantite and, locally, chalcopyrite (Jannas and others, 1991). An alunite-kaolinite assemblage is associated with the early copper-stage veins, and a sericite-kaolinite \pm pyrophyllite assemblage accompanies highgrade gold-stage veins. At Summitville, pre-ore alunite has been replaced by kaolinite (Stoffregen, 1987). Although unambiguous paragenetic data are not reported from other districts, workers studying other quartz-alunite-gold deposits (Arribas and others, 1989; Wang, 1973; Huang, 1955; Johnson, 1951) commonly report that deposition of enargiteluzonite and intense acid leaching and alunitization predate high-grade gold mineralization. Note that similar relationships have been described by other workers (Berger and Henley, 1989; Beane and others, 1991, Sillitoe, in press), wherein high-grade gold ore was deposited from fluids that do not fit the classic conception of "acid-sulfate" deposits.

\section{TRANSPORT OF GOLD AND COPPER IN PORPHYRY COPPER, ENARGITE- PYRITE, AND QUARTZ-ALUNITE- GOLD DEPOSITS}

The deposits discussed above, namely porphyry copper, massive enargite-pyrite, and quartz-alunite-gold veins (table 3), can be separated on the basis of their Ag-to-Au ratios and more particularly their $\mathrm{Cu}$-to-Au ratios (cf., $\mathrm{Cox}$ and Singer, 1988). The similar ratios of copper and gold in porphyry and massive enargite-pyrite deposits and the sharp contrast between their relative abundances in quartz-alunitegold veins suggests that copper and gold transport and deposition occur by similar mechanisms in porphyry and enargite-pyrite deposits but that gold and copper are somehow separated in the formation of quartz-alunite-gold veins. Under the near-magmatic conditions typical of porphyry and related deposits, copper is transported as a chloride complex, most likely $\mathrm{CuCl}$ (Barnes, 1979). Gold, on the other hand, may be transported as either a bisulfide complex, most likely the neutral species $\mathrm{HAu}(\mathrm{HS})_{2}$ (Hayashi and Ohmoto, 1991), or as the chloride complex $\mathrm{AuCl}_{2}^{-}$(Seward, 1984). Recent experimental work (Hayashi and Ohmoto, 1991) has shown

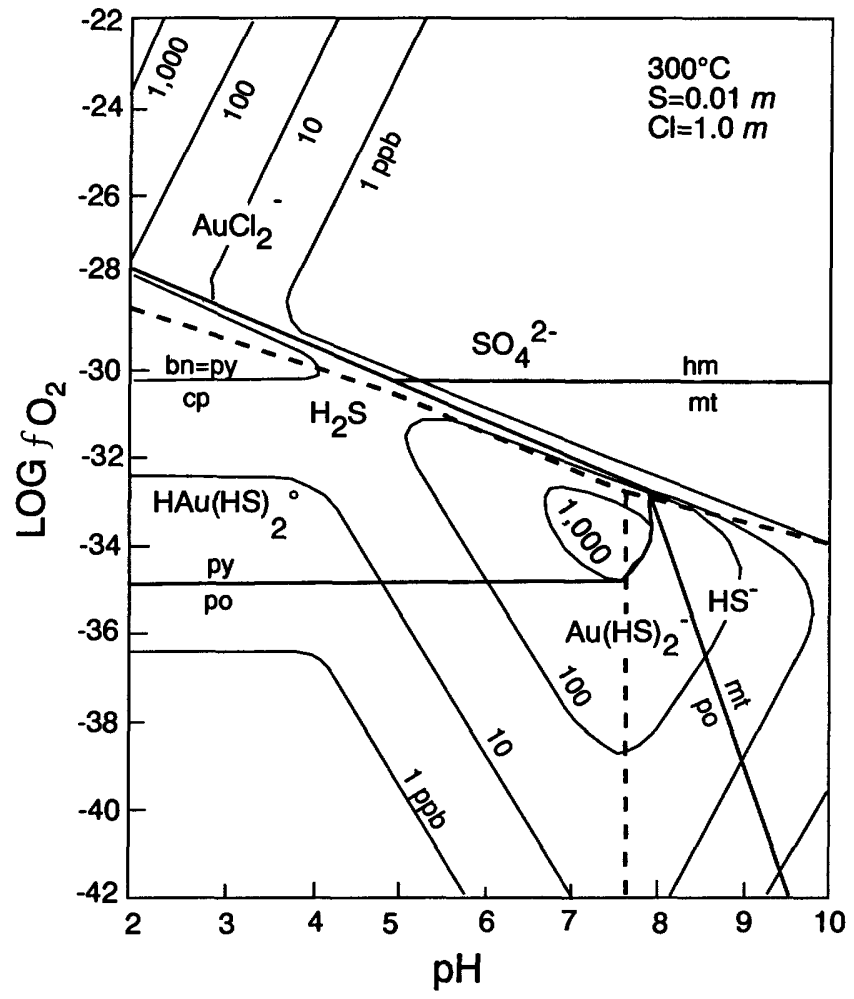

Figure 2. $\log \mathrm{f}_{\mathrm{O}_{2}}$ versus $\mathrm{pH}$ diagram illustrating gold solubility (shown in parts per billion) as $\mathrm{Cl}^{-}$and $\mathrm{HS}^{-}$complexes $\left(\mathrm{AuCl}_{2}{ }^{-}\right.$and $\mathrm{HAu}(\mathrm{HS})_{2}$, respectively). Note the dominance of gold complexed with $\mathrm{Cl}^{-}$under acid and particularly oxidizing conditions, as compared to gold complexed with $\mathrm{HS}^{-}$under relatively reduced conditions (from Hayashi and Ohmoto, 1991). At higher temperatures the solubility of $\mathrm{AuCl}_{2}{ }^{-}$is substantially increased, whereas that for Au-bisulfide complexes is little changed. Heavy lines indicate boundaries of stability fields for solid mineral species. Dashed lines indicate boundaries of stability fields for aqueous species. hm, hematite; mt, magnetite; bn, bornite; py, pyrite; $\mathrm{cp}$, chalcopyrite; po, pyrrhotite.

that, at temperatures between $250^{\circ} \mathrm{C}$ and $350^{\circ} \mathrm{C}$, under most conditions where either pyrite or pyrrhotite is stable, bisulfide complexes predominate (fig. 2). Conditions ${ }^{-}$under which chloride complexes are important in gold transport (fig. 2) are those in which $\mathrm{pH}$ is low and reduced sulfur is not abundant, either because it is subordinate to oxidized sulfur (i.e., an oxidized fluid) or because the total sulfur content is small. Highly saline fluids will also be more likely to carry gold as a chloride complex, both because of the increased complexing ability of $\mathrm{Cl}^{-}$and because of $\mathrm{pH}$ effects (Rose and Burt, 1979). Note that the behavior in solution of silver is intermediate between those of copper and gold (for example, $\mathrm{Cl}^{-}$complexes probably play a dominant role in transport (Seward, 1976)) but, under some circumstances HS $^{-}$ complexes are also important (Gammons and Barnes, 1989). This is in agreement with the $\mathrm{Ag}$-to-Au ratio and $\mathrm{Cu}$-to- $\mathrm{Au}$ ratio data because the variation in Ag-to-Au ratio between deposit types is less extreme than that of $\mathrm{Cu}-$ to- $\mathrm{Au}$. 
Conditions of formation of porphyry copper deposits are indicated by alteration and ore mineral assemblages found in them. In the potassic zone (table 2), assemblages include bornite-magnetite and magnetite-orthoclase-phlogopite. The occurrence of hematite in some deposits, along with the common occurrence of anhydrite, indicates that the fluids were oxidized, with oxidation state close to that of the hematite-magnetite $\mathrm{f}_{\mathrm{O}_{2}}$ buffer. This is consistent with the presence of magnetite+bornite in many (particularly goldrich) porphyry copper deposits (Sillitoe, 1979), which also indicates low fluid $a_{\mathrm{H}_{2} \mathrm{~S}}$ (activity of $\mathrm{H}_{2} \mathrm{~S}$ ). These conditions correspond to conditions under which, according to Hayashi and Ohmoto (1991), gold will be principally carried as $\mathrm{AuCl}_{2}{ }^{-}$. The stability of the $\mathrm{AuCl}_{2}{ }^{-}$complex is much greater at high temperature, such that cooling will be an effective means of precipitating gold (Hayashi and Ohmoto, 1991, table 5). This is in accord with the situation in many goldrich porphyry copper deposits where gold is proportionately much higher in concentration (with respect to copper and silver) in the central part of the deposit (Cuddy and Kesler, 1982; Sillitoe, 1990; Langton and Williams, 1982; Einaudi, 1990).

In highly acid fluids responsible for forming massive enargite-pyrite bodies, low $\mathrm{pH}$ and very oxidized conditions must also result in transport of gold as a chloride complex (Hayashi and Ohmoto, 1991). The similarity of Cu-to-Au ratios in these deposits to those in gold-rich porphyry copper deposits (and again, in turn, with likely compositions of parental magmas) is therefore a reflection of common processes operating in different geochemical environments.

In contrast, the much lower $\mathrm{Cu}$-to-Au ratios typical of high grade quartz-alunite-gold veins probably indicates that some mechanism has operated that has served to separate gold and copper. This may involve either selective transportation or selective precipitation of gold, with selective transport of gold considered the more reasonable cause, given the absence of distal copper-rich zones that would exist if formation of these ores occurred via selective precipitation of gold. Gold-rich, relatively copper poor fluids almost certainly involve transport of gold as a bisulfide complex (Seward, 1991), which is consistent with the character of alteration assemblages associated with quartz-alunite-gold veins. A relatively low salinity is required to account for the low copper grades seen in the gold stage in most examples, in accord with fluid-inclusion data (Jannas and others, 1990).

\section{REMOBILIZATION OF GOLD FROM EARLIER FORMED COPPER-GOLD MINERALIZATION}

Quartz-alunite-gold vein deposits invariably are found within large areas of intensely argillized rock, many of which show some evidence of earlier formed mineralization with much higher $\mathrm{Cu}$-to-Au and Ag-to-Au ratios. This pattern, where main-stage gold deposition follows acid leaching and copper-gold mineralization, is consistent with formation of high-grade gold deposits by remobilization from preexisting, lower grade metal concentrations. The relative solubilities of gold and copper in reduced and nearneutral, as compared to oxidized and acid, fluids would favor preferential leaching of gold (in comparison to copper) in the former, and of copper (in comparison to gold) in the latter.

The situation documented in the Butte district, Montana, is contrary in terms of mobilized components but is conceptually similar to that proposed here: high-grade copper mineralization was formed from remobilization of lowgrade precursor mineralization. At Butte, the high-grade copper sulfosalt ores with advanced argillic alteration selvages cross-cut earlier formed porphyry mineralization that formed under K-silicate-stable conditions. Because copper minerals are volumetrically significant constituents of the early porphyry ores at Butte, Brimhall $(1979,1980)$ was able to convincingly document a history of copper leaching and reconcentration with compositional and textural data. Note that Butte fits the "prograding" sequence of Bartos (1989), and, given the increased solubilities of copper (and other $\mathrm{Cl}^{-}$-complexed metals, including gold under appropriate circumstances) in acid, oxidized fluids, (nonselective) remobilization of base and precious metals during hypogene acidleaching is an expected consequence of the hydrothermal history of the district.

The temporal relations between acid and near-neutral fluids in a retrograding sequence, such as described above for El Indio and Summitville, will not result in large-scale remobilization of copper. It may, however, cause selective. mobilization of gold as a bisulfide species, resulting in formation of the high-grade ores typical of this deposit class.

\section{ORIGIN OF LATE-STAGE NEAR- NEUTRAL REDUCED FLUIDS}

Although quartz-alunite-gold deposits have ore-stage ore-mineral and associated alteration assemblages that are generally similar to those in adularia-sericite-type deposits, the deposit geochemistry (i.e., high concentrations of bismuth and tin-Tolman and Ambrose, 1934; Johnson, 1951; Vikre, 1989; low Ag-to-Au ratio-table 3) is different than most adularia-sericite deposits. This may suggest different mechanisms for the generation of ore-forming fluids in quartz-alunite-gold deposits.

A mechanism for generating these (relatively) reduced fluids is mixing of acidic, magmatic-derived waters with dilute, surface-derived or connate waters that were heated and reduced through interaction with country rocks. The large areas of propylitized rocks associated with argillization in quartz-alunite-gold districts have interacted with considerable volumes of meteoric and (or) formation water. The mineralogical changes associated with propylitization 
(namely formation of epidote, Fe-oxides, carbonates, and chlorite) comprise a set of reactions that result in oxidation of the original country rocks. This must lead to complementary reduction of the circulating fluid. An influx of such a reduced, $\mathrm{Cl}^{-}$-poor fluid into a system previously dominated by acid waters and copper-gold ore deposition could lead to reconcentration of gold into high-grade orebodies. The involvement of such formation waters or highly exchanged meteoric waters in porphyry copper systems has been documented in several areas by oxygen and hydrogen isotope studies (Norman and others, 1991; Bowman and others, 1987).

\section{RELATIONSHIP BETWEEN PORPHYRY COPPER, ENARGITE- PYRITE AND QUARTZ-ALUNITE- GOLD DEPOSITS}

A general spatial and temporal framework for the development of these related ore types emerges from examination of districts where the different deposit types occur together (table 3). The main points of this model are that the sequence "porphyry copper $\rightarrow$ enargite-pyrite massive sulfide (copper and gold bearing) $\rightarrow$ quartz-alunite-gold vein" represents different depths within the overall system, from deepest to shallowest (fig. 3). Quantitative estimates of depth of mineralization for any of these deposit types are scarce, but Vikre (1989) estimates a depth during mineralization at Goldfield of "a few tens of feet to a few hundreds of feet." The occurrence of (apparently) primary jarosite-alunite-barite assemblages at Tambo (Beane and others, 1991) likely represents an extremely shallow level where downwardmoving, oxidized surface waters mixed with ascending, moderately acid fluids. Such a process, which has been documented in more typical hot-spring deposits (Schoen and others, 1974), leads to local, extremely acid conditions and formation of these unusual mineral associations, as well as quantitative precipitation of any gold remaining in solution.

In terms of temporal evolution, field relations in several districts demonstrate that quartz-alunite-gold mineralization postdates deposition of enargite-rich ores (Jannas and others, 1990). The relationship between porphyry-style (K-silicatestable) mineralization and massive enargite-pyrite deposits is less certain, but evidence from Lepanto (Sillitoe, 1983, 1990) and other deposits (R.H. Sillitoe, written commun., 1992) indicates that enargite-pyrite postdates porphyry-style stockwork mineralization. This is in accord with well-documented temporal relations at El Salvador (Gustafson and Hunt, 1975), where advanced argillic assemblages are superimposed on previously formed potassic alteration. The existence of an advanced argillic-enargite-pyrite association, manifested either as massive enargite-pyrite deposits or as an early copper-rich stage in gold veins, seems to be a

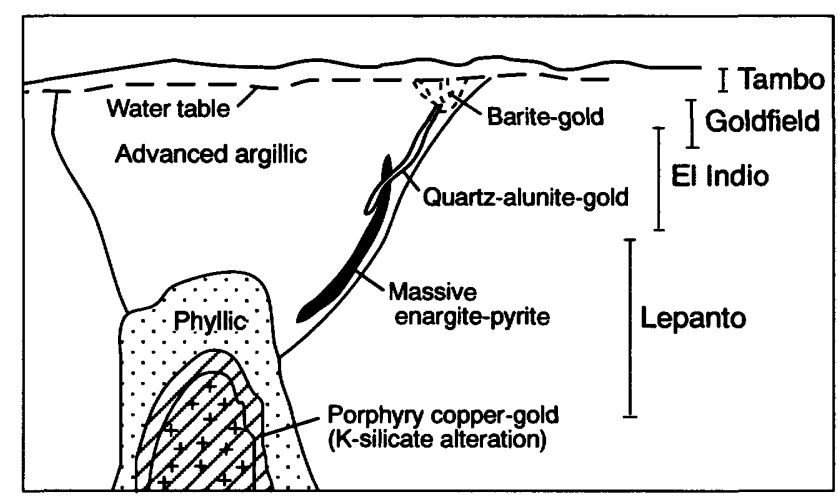

Figure 3. Schematic reconstructed section through mineralized system with porphyry $\mathrm{Cu}$ and related massive enargite-pyrite and quartz-alunite-gold deposits. Note change upward from porphyry copper to massive enargite-pyrite, quartz-alunite-gold veins ( $R$. Araneda, oral commun., 1992), and barite-jarosite vein-hosted Au deposits (Beane and others, 1991). Shown at right are approximate vertical ranges seen in selected districts.

prerequisite for formation of high-grade quartz-alunite-gold deposits, possibly because well-developed structures are necessary for both deposit types.

\section{SUMMARY}

High-grade quartz-alunite-gold deposits are part of a family of magmatic-hydrothermal copper-gold deposits that also includes porphyry copper and massive enargite-pyrite deposits. Porphyry copper deposits generally formed at greatest depth, succeeded upward by enargite-pyrite and quartz-alunite-gold veins. The temporal relations between the different deposit types appears to mimic their spatial relations, with porphyry mineralization earliest, followed by massive enargite-pyrite deposits and finally quartz-alunitegold deposits. The large difference in $\mathrm{Cu}$-to-Au ratios between quartz-alunite-gold and other deposit types indicates that some mechanism has concentrated, and presumably therefore leached and transported, gold preferentially to copper and silver. Gold solubility is high relative to that of copper in reduced, near-neutral fluids. Such fluids may result from a late influx of meteoric water that reacted with heated country rocks. A fluid of this type would be capable of leaching gold from earlier formed copper-gold concentrationsthis is conceptually similar to the mechanism for concentration of copper at Butte.

The observed and inferred history of alteration and fluid chemistry indicates that formation of quartz-alunite-gold deposits is related to the retrograde phase of evolution in systems that have initially followed a prograding path. Not all porphyry copper systems show prograde evolution, and probably fewer still had both well-developed prograde and retrograde stages. This may serve to explain the relative 
scarcity of deposits of this type, in contrast to the abundance of porphyry copper deposits.

Acknowledgments.-This paper is based in part on work done while employed by Corona Gold Inc., and support for research efforts, particularly by Chris Jennings, James Stewart, and Mike Fianacca, is gratefully acknowledged. Discussions with many geologists and comments on various versions of this manuscript by Roger Ashley, Barney Berger, Hal Bonham, Jeff Doebrich, Dick Sillitoe, and James Stewart helped clarify both content and presentation.

\section{REFERENCES CITED}

Arribas, A., Jr., Rytuba, J.J., Rye, R.O., Cunningham, C.G., Podwysocki, M.H., Kelly, W.C., Arribas, A., Sr., McKee, E.H., and Smith, J.G., 1989, Preliminary study of the ore deposits and hydrothermal alteration in the Rodalquilar caldera complex, southeastern Spain: U.S. Geological Survey Open-File Report 89-327, 39 p.

Ashley, R.P., 1974, Goldfield mining district, in Guidebook to the Geology of Four Tertiary Volcanic Centers in Central Nevada: Nevada Bureau of Mines and Geology Report 19, p. 49-66. 1990, The Goldfield gold district, Esmeralda and Nye Counties, Nevada, in Epithermal Gold Deposits-Part I: U.S. Geological Survey Bulletin 1857-H, p. H1-H7.

Ashley, R.P., and Silberman, M.L., 1976, Direct dating of mineralization at Goldfield, Nevada, by potassium-argon and fissiontrack methods: Economic Geology, v. 71, p. 904-924.

Barnes, H.L., 1979, Solubilities of ore minerals, in Barnes, H.L., ed., Geochemistry of Hydrothermal Ore Deposits: New York, John Wiley and Sons, p. 404-460.

Barton, P.B., Jr., and Skinner, B.J., 1979, Sulfide mineral stabilities, in Barnes, H.L., ed., Geochemistry of Hydrothermal Ore Deposits: New York, John Wiley and Sons, p. 278-403.

Bartos, P.J., 1989, Prograde and retrograde base metal lode deposits and their relationship to underlying porphyry copper deposits: Economic Geology, v. 84, p. 1671-1683.

Beane, R.E., 1982, Hydrothermal alteration in silicate rocks: Southwestern North America, in Titley, S.R., ed., Advances in Geology of the Porphyry Copper Deposits, Southwestern North America: Tucson, University of Arizona Press, p. 117-138.

Beane, R.E., Brosnahan, David, Ahler, B., and Jannas, R., 1991, Oxidation of a gold-bearing quartz-sericite-pyrite solutionCalculations and an example from the El Indio district, Chile [abs.]: Geological Society of America, Program with Abstracts, v. 23, p. A464.

Beane, R.E., and Titley, S.R., 1981, Porphyry copper deposits-Part II. Hydrothermal alteration and mineralization, in Skinner, B.J., ed., Economic Geology, 75th Anniversary Volume, p. 235-269.

Berger, B.R., 1986, Descriptive model of epithermal quartz-alunite Au, in Cox, D.P., and Singer, D.A., eds., Mineral Deposit Models: U.S. Geological Survey Bulletin 1693, p. 158.

Berger, B.R., and Henley, R.W., 1989, Advances in the understanding of epithermal gold-silver deposits, with special reference to the Western United States, in Keays, R.R., Ramsay, W.R.H., and Groves, D.I., eds., The Geology of Gold Deposits-The
Perspective in 1988: Economic Geology Monograph 6, p. $405-423$.

Bodnar, R.J., and Beane, R.E., 1980, Temporal and spatial variations in hydrothermal fluid characteristics during vein filling in preore cover overlying deeply buried porphyry copper-type mineralization at Red Mountain, Arizona: Economic Geology, v. 75, p. 876-893.

Bonham, H.F., Jr., 1988, Models for volcanic-hosted epithermal precious metal deposits, in Schafer, R.W., Cooper, J.J., and Vikre, P.G., eds., Bulk Mineable Precious Metal Deposits of the Western United States: Geological Society of Nevada, p. 259-271.

Bowman, J.R., Parry, W.T., Kropp, W.P., and Kruer, S.A., 1987, Chemical and isotopic evolution of hydrothermal solutions at Bingham, Utah: Economic Geology, v. 82, p. 395-428.

Brimhall, G.H., Jr., 1979, Lithologic determination of mass transfer mechanisms of multiple-stage porphyry copper mineralization at Butte, Montana-Vein formation by hypogene leaching and enrichment of potassium-silicate protore: Economic Geology, v. 74, p. 556-589.

-1980 , Deep hypogene oxidation of porphyry copper potassium-silicate protore at Butte, Montana-A theoretical evaluation of the copper remobilization hypothesis: Economic Geology, v. 75, p. 384-409.

Corn, R.M., 1975, Alteration-mineralization zoning at Red Mountain, Arizona: Economic Geology, v. 70, p. 1437-1447.

Cox, D.P., and Singer, D.A., 1988, Distribution of gold in porphyry copper deposits: U.S. Geological Survey Open-File Report $88-46,23$ p.

Cuddy, A.S., and Kesler, S.E., 1982, Gold in the Granisle and Bell Copper porphyry copper deposits, British Columbia, in Levinson, A.A., ed., Precious Metals in the Northern Cordillera: Association of Exploration Geochemists, Special Publication 10, p. 139-155.

Einaudi, M.T., 1990, Zoning of gold and silver in central portions of porphyry copper districts, in Symposium on Geology and Ore Deposits of the Great Basin, Program with Abstracts: Geological Society of Nevada, p. 59-60.

Gammons, C.H., and Barnes, H.L., 1989, The solubility of $\mathrm{AgS}_{2}$ in near-neutral aqueous sulfide solutions at 25 to $300^{\circ} \mathrm{C}$ : Geochimica et Cosmochimica Acta, v. 53, p. 279-290.

Gustafson, L.B., and Hunt, J.P., 1975, The porphyry copper deposit at El Salvador, Chile: Economic Geology, v. 70, p. 857-912.

Hayashi, K-I., and Ohmoto, H., 1991, Solubility of gold in $\mathrm{NaCl}$ and $\mathrm{H}_{2} \mathrm{~S}$-bearing aqueous solutions at $250-350^{\circ} \mathrm{C}$ : Geochimica et Cosmochimica Acta, v. 55, p. 2111-2126

Heald, P., Foley, N.K., and Hayba, D.O., 1987, Comparative anatomy of volcanic-hosted epithermal deposits-Acid-sulfate and adularia-sericite types: Economic Geology, v. 82, p. 1-26.

Hemley, J.J., and Hunt, J.P., 1992, Hydrothermal ore-forming processes in light of studies in rock-buffered systems-II. Some general geologic applications: Economic Geology, v. 87, p. 23-43.

Hernandez, P.A., Garcia-Estrada, P.A., and Cowley, P.N., 1989, Geological setting, alteration and lithogeochemistry of the Transaccion epithermal gold deposit, Rodalquilar mining district, southeast Spain: Transactions, Institute of Mining and Metallurgy, v. 98, p. B78-B80. 
Huang, C.K., 1955, Gold-copper deposits of the Chinkuashih mine, Taiwan, with special reference to the mineralogy: Acta Geologica Taiwanica, v. 7, p. 1-20.

1960, Gold deposits of the Wutanshan area, Taiwan, and their relation to the Chinkuashih deposits: Acta Geologica Taiwanica, v. 8, p. 13-25.

1963, Factors controlling the gold-copper deposits of the Chinkuashih Mine, Taiwan: Acta Geologica Taiwanica, v. 10, p. 1-9.

Huang, C.K., and Yeh, K.S., 1977, Special features of the ore deposits of the Changjen Series, Chinkuashih mine, Taiwan: Acta Geologica Taiwanica, v. 19, p. 1-12

Jannas, R.R., Beane, R.E., Ahler, B.A., and Brosnahan, D.R., 1990, Gold and copper mineralization at the El Indio deposit, Chile: Journal of Geochemical Exploration, v. 36, p. 233-266.

Jannas, R., Bowers, T.S., and Petersen, U., 1991, Fluid chemistry modeling of gold and copper mineralization in acid-sulfate type gold deposits, El Indio mine, Chile [abs.]: Geological Society of America Program with Abstracts, v. 23, p. A464.

John, D.A., Thomason, R.E., and McKee, E.H., 1989, Geology and $\mathrm{K}$-Ar geochronology of the Paradise Peak mine and the relationship of pre-Basin and Range extension to early Miocene precious metal mineralization in west-central Nevada: Economic Geology, v. 631-649.

Johnson, R.F., 1951, Geology of the Masonic mining district, Mono County, California: Berkeley, University of California, M.S. thesis, $51 \mathrm{p}$.

Keith, W.J., Calk, L., and Ashley, R.P., 1980, Crystals of coexisting alunite and jarosite, Goldfield, Nevada: U.S. Geological Survey Professional Paper 1124-A-F, p. Cl-C5.

Krauskopf, K.B., 1979, Introduction to Geochemistry (2nd ed.): New York, McGraw-Hill, 617 p.

Langton, J.M., and Williams, S.A., 1982, Structural, petrological and mineralogical controls for the Dos Pobres orebody, in Titley, S.R., ed., Advances in Geology of the Porphyry Copper Deposits, Southwestern North America: Tucson, University of Arizona Press, p. 335-352

Large, R.R., Huston, D.L., McGoldrick, P.J., Ruxton, P.A., and McArthur, G., 1989, Gold distribution and genesis in Australian volcanogenic massive sulfide deposits and their significance for gold transport models, in Keays, R.R, Ramsay, W.R.H., and Groves, D.I., eds., The Geology of Gold Deposits-The Perspective in 1988: Economic Geology Monograph 6, p. 520-536.

Lindley, I.D., 1987, The discovery and exploration of the Wild Dog gold-silver-copper deposit, East New Britain, P.N.G.: Melbourne, Australasian Institute of Mining and Metallurgy, Proceedings, Pacific Rim Congress 87, p. 283-286.

Lowell, J.D., and Guilbert, J.M., 1970, Lateral and vertical alteration-mineralization zoning in porphyry ore deposits: Economic Geology, v. 65, p. 373-408.

Meyer, C., and Hemley, J.J., 1967, Wall rock alteration, in Barnes, H.L., ed., Geochemistry of Hydrothermal Ore Deposits: New York, Holt, Rinehart, and Winston, p. 166-235.

Morris, H.T., 1968, The main Tintic mining district, Utah, in Ridge, J.D., ed., Ore Deposits of the United States, 1933-1967, The Graton-Sales Volume: American Institute of Mining and Metallurgy, v. II, p. 1043-1073.

Mosier, D.L., and Menzie, W.D., 1986, Grade and tonnage model of quartz-alunite-Au, in Cox, D.P., and Singer, D.A., eds.,
Mineral Deposit Models: U.S. Geological Survey Bulletin 1693, p. 159-161.

Norman, D.K., Parry, W.T., and Bowman, J.R., 1991, Petrology and geochemistry of propylitic alteration at southwest Tintic, Utah: Economic Geology, v. 86, p. 13-28.

Oviedo, L., Fuster, N., Tschischow, N., Ribba, L., Zuccone, A., Grez, E., and Aguilar, A., 1991, General geology of La Coipa precious metal deposit, Atacama, Chile: Economic Geology, v. 85 , p. $1287-1300$.

Rose, A.W., and Burt, D.M., 1979, Hydrothermal alteration, in Barnes, H.L., ed., Geochemistry of Hydrothermal Ore Deposits (2nd ed.): New York, John Wiley, p. 173-235.

Ransome, F.L., 1909, Geology and ore deposits of Goldfield, Nevada: U.S. Geological Survey Professional Paper 66, 258 p.

Rytuba, J.J., Arribas, A., Jr., Cunningham, C.G., McKee, E.H., Podwysocki, M.H., Smith, J.G., Kelly, W.C., and Arribas, A., Sr., 1990, Mineralized and unmineralized calderas in SpainPart II, Evolution of the Rodalquilar caldera complex and associated gold-alunite deposits: Mineralium Deposita, v. 25, p. S29-S35.

Rytuba, J.J., Arribas, A., Jr., Cunningham, C.G., McKee, E.H., Smith, J.G., and Arribas, A., Sr., 1989, Evolution of the Rodalquilar caldera complex and associated gold-alunite deposits, Cabo de Gato volcanic field, southeastern Spain: U.S. Geological Survey Open File Report 89-326, 18 p.

Schoen, R., White, D.E., and Hemley, J.J., 1974, Argillization by descending acid at Steamboat Springs, Nevada: Clays and Clay Minerals, v. 22, p. 1-22.

Seward, T.M., 1976, The stability of chloride complexes of silver in hydrothermal solutions up to $350^{\circ} \mathrm{C}$ : Geochimica et Cosmochimica Acta, v. 40, p. 1329-1341.

1984, The transport and deposition of gold in hydrothermal systems, in Foster, R.P., ed., Gold '82: Rotterdam, A.A. Balkema Publishing, p. 121-134.

1991, The hydrothermal geochemistry of gold, in Foster, R.P., ed., Gold Metallogeny and Exploration: Glasgow, Blackie, p. 37-62.

Siddeley, G., and Araneda, R., 1986, The El Indio-Tambo gold deposits, Chile, in MacDonald, A.J., ed., Proceedings of Gold '86, an International Symposium on the Geology of Gold: Toronto, p. 445-456.

Sillitoe, R.H., 1973, The tops and bottoms of porphyry copper deposits: Economic Geology, v. 68, p. 799-815.

-1979 , Some thoughts on gold-rich porphyry copper deposits: Mineralium Deposita, v. 14, p. 161-174.

1983, Enargite-bearing massive sulfide deposits high in porphyry copper systems: Economic Geology, v. 78, p. $348-352$.

1988, Gold and silver deposits in porphyry systems, in Schafer, R.W., Cooper, J.J., and Vikre, P.G., eds., Bulk Mineable Precious Metal Deposits of the Western United States: Geological Society of Nevada, p. 233-257.

1989, Gold deposits in western Pacific island arcs-The magmatic connection, in Keays, R.R, Ramsay, W.R.H., and Groves, D.I., eds., The Geology of Gold Deposits-The Perspective in 1988: Economic Geology Monograph 6, p. 266-283.

-1990 , Gold-rich porphyry copper deposits of the circum-Pacific region-An updated overview, in Pacific Rim Congress '90, Gold Coast, Queensland 1990, Proceedings, v. 2: 
Melbourne, Australasian Institute of Mining and Metallurgy, p.119-126.

-in press, Epithermal models-Genetic types, geometrical controls, and shallow features, in Kirkham, R.V., ed., Mineral Deposit Modeling: Geological Association of Canada Special Paper.

Sillitoe, R.H., Angeles, C.A., Comia, G.M., Antioquia, E.C., and Abeya, R.B., 1990, An acid-sulfate-type lode gold deposit at Nalesbitan, Luzon, Philippines: Journal of Geochemical Exploration, v. 35 , p. 387-411.

Steven, T.A., and Ratte, J.C., 1960, Geology and ore deposits of the Summitville district, San Juan Mountains, Colorado: U.S. Geological Survey Professional Paper 343, 70 p.

Stoffregen, R., 1987, Genesis of acid-sulfate alteration and $\mathrm{Au}-\mathrm{Cu}-$ Ag mineralization at Summitville, Colorado: Economic Geology, v. 82, p. 1575-1591.
Tan, L-P., 1991, The Chinkuashih gold-copper deposits, Taiwan: Society of Economic Geologists Newsletter, no. 7, v. 1, p. 22-24.

Taylor, G., 1987, Breccia formation and its relation to gold mineralization at Mount Kasi, Fiji: Proceedings Pacific Rim Congress 87: Melbourne, Australasian Institute of Mining and Metallurgy, p. 597-601.

Tolman, C.F., and Ambrose, J.W., 1934, The rich ores of Goldfield, Nevada: Economic Geology, v. 29, p. 255-279.

Vikre, P.G., 1989, Ledge formation at the Sandstorm and Kendall gold mines, Goldfield, Nevada: Economic Geology, v. 84, p. 2115-2138.

Wang, Y., 1973, Wall rock alteration of late Cenozoic mineral deposits in Taiwan-Mineralogical and physicochemical aspects: Acta Geologica Taiwanica, v. 16, p. 1-29. 


\title{
CHAPTER F
}

\section{REMOTE-SENSING SPECTRAL PROPERTIES OF SELECTED INDUSTRIAL MINERALS AND ORES}

\author{
By James K. Crowley ${ }^{1}$
}

\begin{abstract}
Spectral-reflectance and thermal-emission properties of 19 selected industrial minerals and ores were examined to evaluate the possibility of mineral detection using spectroscopic remote-sensing data. The results show that use of visible and near-infrared data is potentially suitable for discerning borates, carbonates, diatomite, gypsum, pyrophyllite, talc, and vermiculite. Thermal-infrared data may be particularly useful for locating concentrations of barite, quartz, perlite, phosphorite, and thenardite. Some minerals, such as zeolites, may not be amenable to remote-sensing detection because of near-infrared absorption interference by atmospheric water vapor and the occurrence of these minerals in fine-grained samples that have low thermal-infrared spectral contrast. Further research is needed to study how weathering processes and mixtures of surficial materials may affect remote sensing of industrial minerals and ores under actual field conditions.
\end{abstract}

\section{INTRODUCTION}

Industrial minerals and ores include a wide variety of commodities, ranging from exotic substances, such as rare earth elements, to more commonplace materials, such as sand and gravel. Because of this diversity, industrial minerals and ores defy a simple definition. Industrial minerals are frequently referred to as "nonmetallics," even though this designation does not precisely fit materials like bauxite ore, lithium concentrates, and titanium oxides. Depending on how limiting a definition is applied, the annual dollar value of industrial minerals produced worldwide is as much as

${ }^{1}$ U.S. Geological Survey, Mail Stop 927, 12201 Sunrise Valley Drive, Reston, VA 22092-0001. twice the annual value of production from precious- and base-metal ore deposits (Bates, 1983).

The purpose of this study is to examine the spectralreflectance and thermal-emission properties of selected industrial minerals and ores and to evaluate prospects for locating mineral commodities with spectroscopic remotesensing data. Sophisticated airborne scanners, such as the NASA airborne visible/infrared imaging spectrometer (AVIRIS), can remotely measure spectral curves that compare favorably in quality and detail to curves obtainable with laboratory spectrometers (Vane and others, 1993). Such spectral curves can be used to observe characteristic absorption features produced by Earth-surface materials, including particular minerals, rocks, soils, and plant types. Also important is the recent development of portable spectrometers that permit real-time measurements of mineral and vegetation spectra in the field. Portable spectrometers are being used for mapping hydrothermally altered rocks and in studies of heavy metal concentrations in mine tailings (Munts and others, 1993; Ebel and others, 1993). Field spectral measurements may also have a useful role in ore quality assessment (J.K. Crowley, unpub. data). Although a number of general reviews dealing with the spectral properties of minerals and rocks are available (e.g., Hunt, 1977; Clark and others, 1990; Salisbury and others, 1991), none deals explicitly with industrial minerals. Similarly, the potential use of remotesensing data as an aid to exploration for industrial minerals has received only limited attention. In a spectral study of carbonatites and associated alkalic rocks, Rowan and others (1986) commented that rare-earth absorption bands might be observable with remote-sensing data, and such features subsequently have been detected (Kingston and Crowley, 1992). Crowley and others (1989) demonstrated that visible and near-infrared (VNIR; 0.4 to $2.5 \mu \mathrm{m}$ ) remote-sensing data might be useful for talc exploration, and Crowley (1993) reported on the use of high-spectral-resolution AVIRIS data for mapping saline evaporite minerals, including borates. Kingston (1989) has also reported on the VNIR spectral 
Table 1. Information on sample deposit types, localities, and mineralogical compositions as determined by $\mathrm{X}$-ray diffraction analysis.

\begin{tabular}{lll}
\hline \multicolumn{1}{c}{ Sample } & \multicolumn{1}{c}{ Deposit type and locality } & \multicolumn{1}{c}{ Composition } \\
\hline Thenardite & Playa; Saline Valley, California & Thenardite \\
Barite 1 & Bedded; Slaven Canyon, Nevada & Barite \\
Barite 2 & Bedded; Osgood Mtns., Nevada & Barite \\
Phosphorite & Marine; Phosphoria Formation, Idaho & $\begin{array}{l}\text { Quartz, calcite, } \\
\text { carbonate-fluorapatite }\end{array}$ \\
& & \\
Quartz & Sandstone; Tuscarora Sandstone, & Quartz \\
& West Virginia & Glass (amorphous) \\
Perlite 1 & Volcanic; Saguache Co., Colorado & Glass (amorphous) \\
Perlite 2 & Volcanic; Mohave Co., Arizona & Quartz, muscovite, calcite, \\
Graphite & Schist; Washington Co., New York & graphite \\
& \multicolumn{2}{c}{ Samples shown in figures 2 and 5 } \\
\hline \multicolumn{3}{c}{ I } \\
\hline Diatomite & Lacustrine; Stewart, Nevada & Amorphous silica \\
Calcite & Limestone; Confusion Range, Utah & Calcite \\
Kimberlite & Volcanic pipe; Zeekoegat, S. Africa & Calcite, phlogopite, serpentine \\
Erionite & Sedimentary tuff; Eureka Co., Nevada & Erionite, merlinoite \\
Phillipsite & Sedimentary tuff; Eureka Co., Nevada & Phillipsite \\
Gypsum & Playa; Mesquite Playa, California & Gypsum \\
\hline \multicolumn{3}{c}{ Samples shown in figures 3 and 6 } \\
\hline Pyrophyllite & Hydrothermal; Pilot Mtn., North Carolina & Pyrophyllite \\
Talc & Metasedimentary; Ruby Mtns., Montana & Talc \\
Vermiculite & Unknown; Llano Co., Texas & Vermiculite, amphibole \\
Ulexite & Lacustrine; Boron, California & Ulexite \\
Colemanite & Lacustrine; Boron, California & Colemanite \\
\hline
\end{tabular}

properties of kimberlites, with a view toward the use of remote-sensing data to explore for diamonds.

The present report will focus on selected industrial minerals and ores that generally meet two criteria: First, the minerals must occur in surficial exposures that potentially are amenable to remote-sensing detection. Second, most of the minerals included have relatively high intrinsic value. Highpurity quartz sand and calcitic carbonate rock samples are also included in the study because of their distinctive spectral properties and the possibility that remote-sensing exploration for these commodities may be economically practical in some situations. The study is not comprehensive because many industrial minerals are not included and the minerals represented here by only one or two samples may exhibit considerable natural variation. Further research is planned to examine additional samples and to investigate other factors, such as weathering stability, which may affect remote-sensing detection of the minerals and ores.

\section{METHODS}

A collection of industrial minerals and ores was obtained from U.S. Geological Survey commodity geologists and supplemented by samples on hand from previous geologic remote-sensing studies (table 1). The samples generally represent the more important deposit types for each industrial mineral, according to deposit descriptions given in Lefond (1983). For most of the minerals and ores, multiple samples were examined spectrally, and representative specimens were then used for this report. Table 1 includes information on sample deposit types, localities, and mineralogical compositions based on X-ray diffraction analysis.

Visible and near-infrared (0.4-2.5 $\mu \mathrm{m})$ reflectance spectra were recorded on a Beckman Instruments UV 5240 spectrometer equipped with an integration sphere. The data were acquired digitally and corrected for errors in the 100 percent line caused by the instrument and the white halon reference material (Crowley and others, 1986). Hemispherical reflectance spectra were measured in the thermal-infrared $(2.5-13.5 \mu \mathrm{m})$ by using a Nicolet 5DXB FTIR spectrometer equipped with a gold-coated integration sphere, a diffuse gold reference plate, and an infrared source (Salisbury and others, 1988). The hemispherical reflectance spectra were subsequently converted to emission spectra by using Kirchoff's law (Salisbury and others, 1988). Because the thermal-infrared (TIR) spectral signatures of principal interest from a remote-sensing standpoint are those within the $8-13.5-\mu \mathrm{m}$ atmospheric transmission window, the present study focuses on this wavelength interval. Whenever 
practical, both VNIR and TIR spectra were measured on natural surfaces of whole-rock sample chips. In cases where the surfaces were too irregular, samples were ground to a coarse powder (approximately $250 \mu \mathrm{m}$ ) and poured into a sample cup for spectral measurements.

To evaluate TIR remote-sensing prospects for industrial minerals and ores, the sample spectra were convolved to the six spectral bandpasses of the NASA thermal-infrared multispectral scanner (TIMS). A spectral library of TIR data for 43 well-characterized igneous and sedimentary rocks (Salisbury and others, 1988; J.W. Salisbury, unpub. data) was also convolved to the TIMS bandpasses, permitting the rock spectral responses and industrial mineral spectral responses to be compared.

\section{RESULTS}

Figures 1 through 3 show VNIR spectra of the industrial minerals and ores examined in this study. Table 2 lists absorption band positions for each sample along with general band assignments. With a few notable exceptions, most of the samples exhibit relatively featureless VNIR spectra, or they show absorption bands that have limited utility from a remote-sensing standpoint because of interference by atmospheric absorption features. In particular, many of the spectra in figures 1 and 2 exhibit absorption bands near 1.4 and $1.9 \mu \mathrm{m}$ related to molecular water (Hunt and Salisbury, 1970; Aines and Rossman, 1984). These water features cannot be observed remotely because the same wavelengths are obscured by atmospheric water-vapor absorption. In contrast, the 2.1-2.45- $\mu \mathrm{m}$ wavelength range has minimal atmospheric interference, and several of the figure 1 spectra show weak features in this wavelength region related to minor clay (present in weathered feldspar), K-mica, and carbonate mineral constituents (table 1). However, none of these spectral features in figure 1 are diagnostic of the contained industrial minerals. The figure 2 samples, in most cases, show greater spectral contrast (absorption band intensity) than the figure 1 samples and do exhibit absorption features that are caused directly by the industrial mineral constituents. In the cases of diatomite and gypsum, diagnostic absorption features in the 2.1-2.45- $\mu \mathrm{m}$ wavelength range produced by structural water molecules would probably permit identification of these minerals in a remote-sensing context. The calcitic carbonate rock shows a strong absorption feature near $2.335 \mu \mathrm{m}$, which is related to vibrational absorption processes involving the $\mathrm{CO}_{3}$ anion group (Hunt, 1977). On the other hand, the calcitic kimberlite sample lacks obvious absorption features, probably because of strong masking absorption by opaque carbonaceous impurities. Remote-sensing detection of the two zeolite minerals would also be problematic because they lack diagnostic features outside the 1.4- and 1.9- $\mu \mathrm{m}$ wavelength regions of atmospheric water-vapor absorption.

The minerals shown in figure 3 all have diagnostic spectral features between 2.1 and $2.45 \mu \mathrm{m}$ that should permit

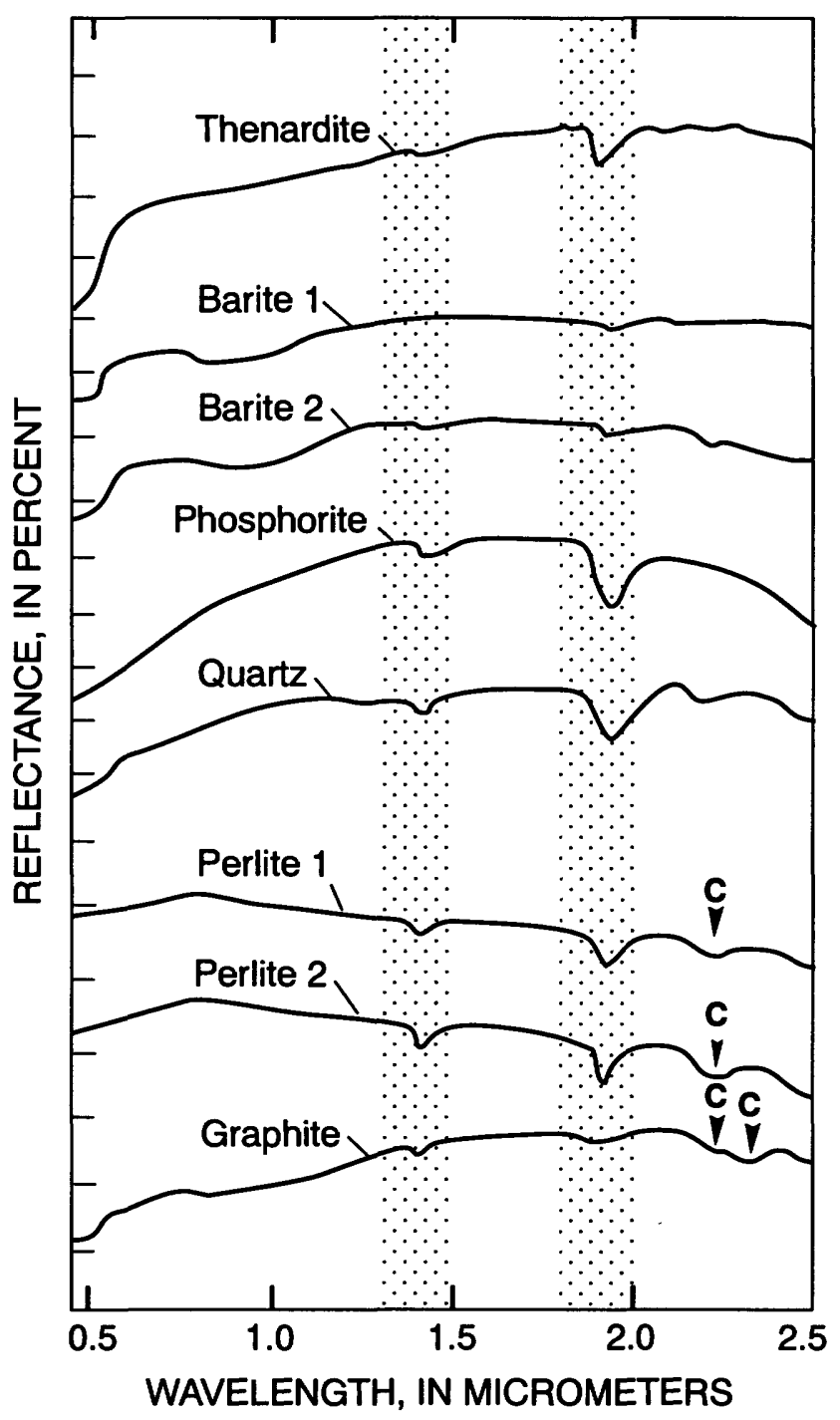

Figure 1. Visible and near-infrared (VNIR) reflectance spectra of industrial minerals and ores. Spectra are offset vertically for viewing purposes. Tickmarks on vertical axis show reflectance intervals of 10 percent. Stippling indicates wavelength regions obscured by atmospheric water-vapor absorption. Arrows with letter "c" indicate absorption features caused by contaminant clay minerals, K-mica, and calcite. Reflectance values of each spectrum at 2.5 $\mu \mathrm{m}$ are (from top to bottom) 69 percent, 26 percent, 25 percent, 26 percent, 54 percent, 8 percent, 7 percent, and 25 percent.

their remote-sensing identification with suitable VNIR data (table 2). In the case of pyrophyllite, the absorption features are caused by vibrational absorption processes involving aluminum and hydroxyl, whereas, in talc and vermiculite, the features are due to vibrational processes involving magnesium and hydroxyl (Hunt, 1977). The two borate minerals, ulexite and colemanite, exhibit bands due to hydrate water molecules and perhaps to vibration modes of the borate anion group (Hunt and others, 1972). Hunt and Salisbury (1970), Hunt (1977), Clark and others (1990), and Crowley (1991) provide additional information on the types of 


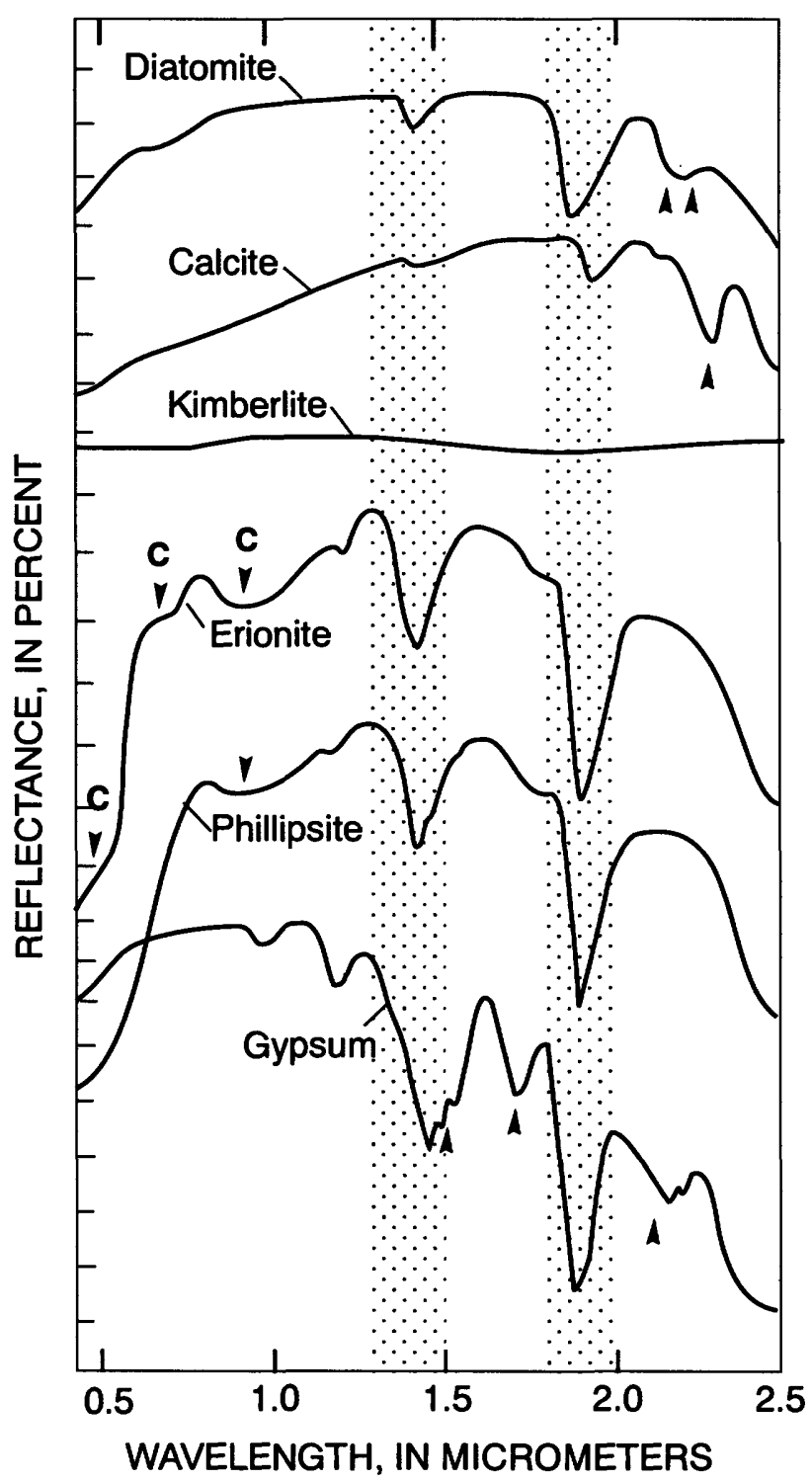

Figure 2. Visible and near-infrared (VNIR) reflectance spectra of industrial minerals and ores. Spectra are offset vertically for viewing purposes. Tickmarks on vertical axis show reflectance intervals of 10 percent. Stippling indicates wavelength regions obscured by atmospheric water-vapor absorption. Plain arrows mark positions of diagnostic absorption features listed in table 2. Arrows with letter "c" indicate absorption features caused by contaminant iron oxide minerals. Reflectance values of each spectrum at $2.5 \mu \mathrm{m}$ are (from top to bottom) 58 percent, 31 percent, 7 percent, 32 percent, 22 percent, and 17 percent.

absorption features commonly observed in the VNIR reflectance spectra of minerals and rocks.

Figures 4 through 6 show TIR emission spectra of the industrial mineral and ore samples. Examination of figure 4 reveals that several samples, which were spectrally featureless in the VNIR wavelength range (fig. 1), exhibit strong TIR spectral features. In particular, the thenardite and barite spectra show features associated with fundamental molecular vibrations of the sulfate anion group, and the phosphorite

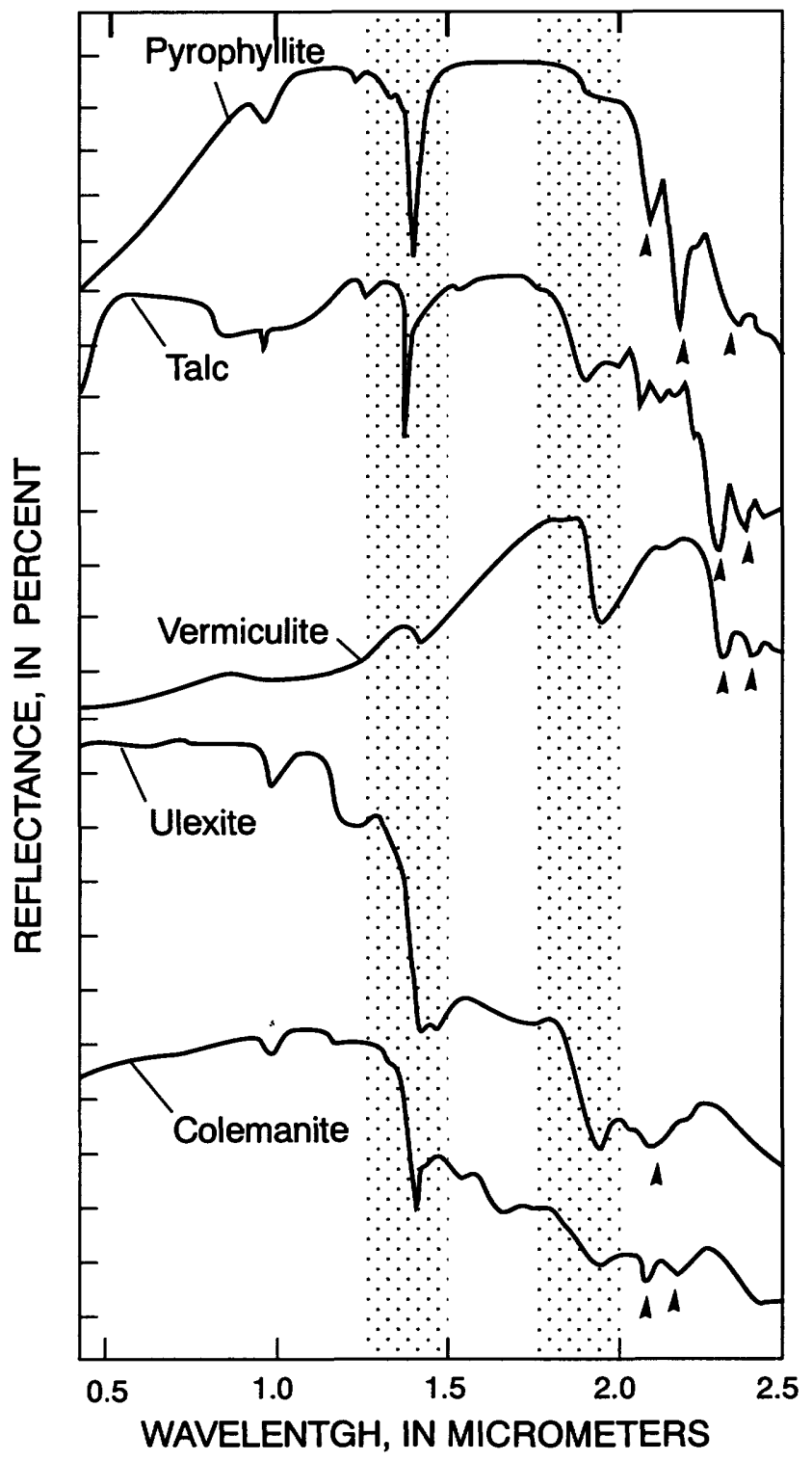

Figure 3. Visible and near-infrared (VNIR) reflectance spectra of industrial minerals and ores. Spectra are offset vertically for viewing purposes. Tickmarks on vertical axis show reflectance intervals of 10 percent. Stippling indicates wavelength regions obscured by atmospheric water-vapor absorption. Arrows mark positions of diagnostic absorption features listed in table 2 . Reflectance values of each spectrum at $2.5 \mu \mathrm{m}$ are (from top to bottom) 18 percent, 22 percent, 16 percent, 11 percent, and 27 percent.

spectrum exhibits features attributable to the phosphate group (Farmer, 1974). The perlite spectra exhibit broad emission features due to silicon-oxygen stretching and bending modes, which evidently extend over a wide range of energies in these structureless silicate glasses. Silicon-oxygen vibrational modes also account for the well-defined features seen in the quartz-sand spectrum.

In contrast with figure 4 , most of the TIR spectra shown in figure 5 are spectrally featureless. The reasons for this are 
Table 2. Diagnostic absorption features and band assignments for industrial minerals and ores.

[Leaders (--) indicate no features present]

\begin{tabular}{|c|c|c|}
\hline Mineral/ore & Band positions $(\mu \mathrm{m})$ & Assignment \\
\hline \multicolumn{3}{|c|}{ Samples shown in figures 1 and 4} \\
\hline Thenardite & $8.46,8.82$ & $\mathrm{SO}_{4}$ \\
\hline Barite 1 & $8.18,8.84$ & $\mathrm{SO}_{4}$ \\
\hline Barite 2 & $8.18,8.85$ & $\mathrm{SO}_{4}$ \\
\hline Phosphorite & $9.02,9.57$ & $\mathrm{PO}_{4}$ \\
\hline Quartz & $8.24,9.17$ & $\mathrm{SiO}_{4}$ \\
\hline Perlite 1 & 9.45 & $\mathrm{SiO}_{4}$ \\
\hline Perlite 2 & 9.17 & $\mathrm{SiO}_{4}$ \\
\hline Graphite & -- & - \\
\hline \multicolumn{3}{|c|}{ Samples shown in figures 2 and 5} \\
\hline Diatomite & $2.195,2.26$ & $\mathrm{Si}-\mathrm{OH}$ \\
\hline Calcite & $2.335,11.24$ & $\mathrm{CO}_{3}$ \\
\hline Kimberlite & 11.34 & $\mathrm{CO}_{3}$ \\
\hline Erionite & -- & - \\
\hline Phillipsite & -- & - \\
\hline Gypsum & $1.53,1.74,2.208,8.65$ & $\mathrm{H}_{2} \mathrm{O}, \mathrm{SO}_{4}$ \\
\hline \multicolumn{3}{|c|}{ Samples shown in figures 3 and 6} \\
\hline Pyrophyllite & $2.08,2.165,2.32,8.73,9.12$ & $\mathrm{Al}-\mathrm{OH}, \mathrm{SiO}_{4}$ \\
\hline Talc & $2.305,2.38,8.98,9.62$ & $\mathrm{Mg}-\mathrm{OH}, \mathrm{SiO}_{4}$ \\
\hline Vermiculite & $2.305,2.38,9.49$ & $\mathrm{Mg}-\mathrm{OH}, \mathrm{SiO}_{4}$ \\
\hline Ulexite & $2.168,11.59$ & $\mathrm{H}_{2} \mathrm{O}, \mathrm{BO}_{3}$ \\
\hline Colemamite & $2.104,2.196,10.47,10.87$ & $\mathrm{H}_{2} \mathrm{O}, \mathrm{BO}_{3}$ \\
\hline
\end{tabular}

twofold: First, some of the figure 5 samples (diatomite, and the two zeolites) are naturally fine grained, a property that sharply reduces the TIR spectral contrast (see Salisbury and others, 1988). Second, whereas the VNIR spectra of these samples (fig. 2) showed features attributable to molecular water, the analogous TIR water-absorption features lie outside the wavelength range covered by the emission spectra. Note that the gypsum emission feature seen in figure 5, similar to the features noted above for thenardite and barite, is due to molecular vibration modes of the sulfate anion group and not to molecular water (Farmer, 1974). The calcite and kimberlite spectra show weak carbonate bands near $11.2 \mu \mathrm{m}$, which in the case of kimberlite may be too subtle for remotesensing detection with TIMS data; however, this spectral feature might be stronger in other kimberlite samples.

Most of the TIR spectra in figure 6 show moderately strong spectral features. The ulexite spectrum is an exception, and its reduced spectral contrast again is a result of this sample's relatively fine particle size. The emission features seen in the spectra of pyrophyllite, talc, and vermiculite all involve internal vibration modes of the silicate anion group; the colemanite emission features observed near $10.6 \mu \mathrm{m}$ are produced by molecular vibrations of the borate anion group (Farmer, 1974).

Table 3 compares TIMS band-ratio values, calculated from igneous and sedimentary rock spectra, to similar band ratios calculated from the industrial mineral TIR spectra. From the table it can be seen that certain industrial minerals

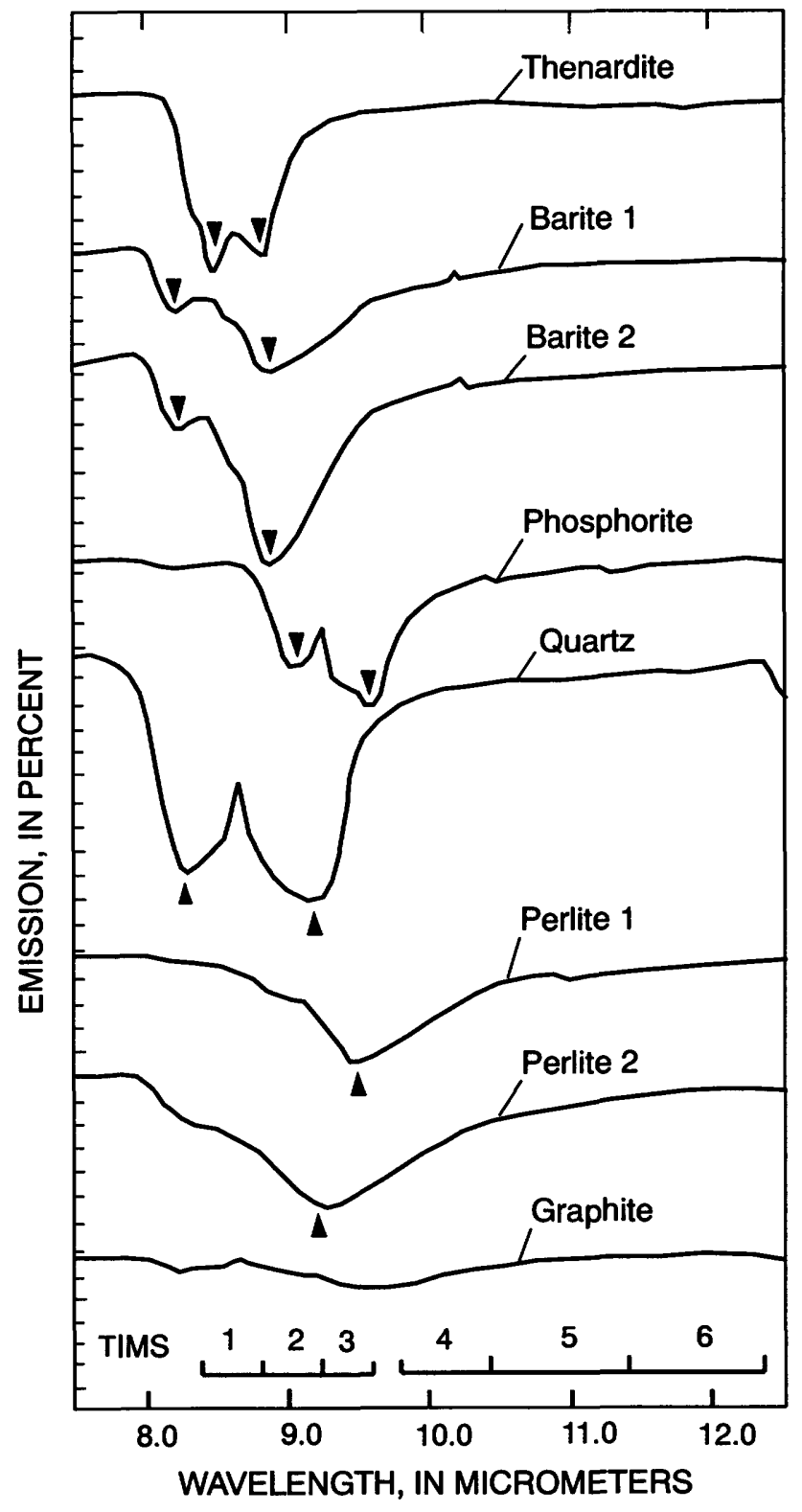

Figure 4. Thermal emission spectra of industrial minerals and ores. Spectra are offset vertically for viewing purposes, and TIMS (thermal-infrared multispectral scanner) bandpasses are shown on the lower part of the figure. Tickmarks on vertical axis indicate emission intervals of 5 percent. Arrows mark positions of diagnostic absorption features listed in table 2. Emission values of each spectrum at $12.5 \mu \mathrm{m}$ are (from top to bottom) 97 percent, 95 percent, 94 percent, 95 percent, 96 percent, 96 percent, 95 percent, and 88 percent.

are spectrally distinct from common rocks that might be encountered in a remote-sensing situation. For example, the thenardite and gypsum samples have relatively high $3 / 1$ ratio values compared to typical sedimentary host rocks. Similarly, the two perlite samples have relatively low $3 / 1$ ratios, making them spectrally distinct from most common igneous rocks. The colemanite sample has a high $4 / 6$ ratio, and the two barites have low $2 / 1$ ratio values, which may permit their 


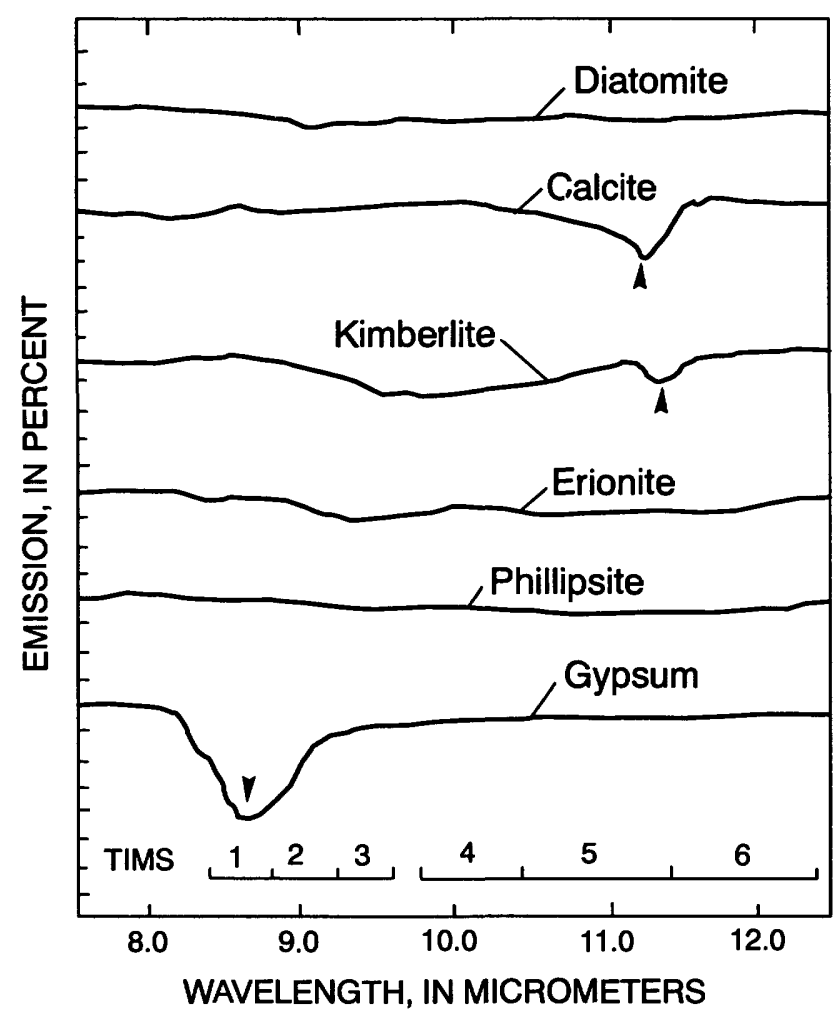

Figure 5. Thermal emission spectra of industrial minerals and ores. Spectra are offset vertically for viewing purposes, and TIMS (thermal-infrared multispectral scanner) bandpasses are shown on the lower part of the figure. Tickmarks on vertical axis indicate emission intervals of 5 percent. Arrows mark positions of diagnostic absorption features listed in table 2. Emission values of each spectrum at $12.5 \mu \mathrm{m}$ are (from top to bottom) 98 percent, 98 percent, 98 percent, 98 percent, 98 percent, and 97 percent.

remote-sensing discrimination. Quartz has a high $4 / 3$ ratio value and phosphorite a relatively high $2 / 3$ ratio compared to analogous ratio values for igneous and sedimentary rocks. The particular band-ratio combinations shown in table 3 were selected by inspection of the 15 possible ratio combinations to find those that were most useful. It should be emphasized that other ratio combinations and other analytical techniques, such as spectral shape matching, may also be effective for distinguishing particular minerals. More importantly, it should be remembered that different samples of particular industrial minerals and ores are likely to exhibit some degree of spectral variation. Table 3 should therefore be regarded only as a preliminary guide to the use TIMS ratios for distinguishing industrial minerals.

\section{DISCUSSION}

The results of the study indicate that VNIR and TIR spectral data may permit remote-sensing discrimination of a variety of industrial minerals and ores. VNIR data may facilitate detection of borates, carbonates, diatomite, gypsum,

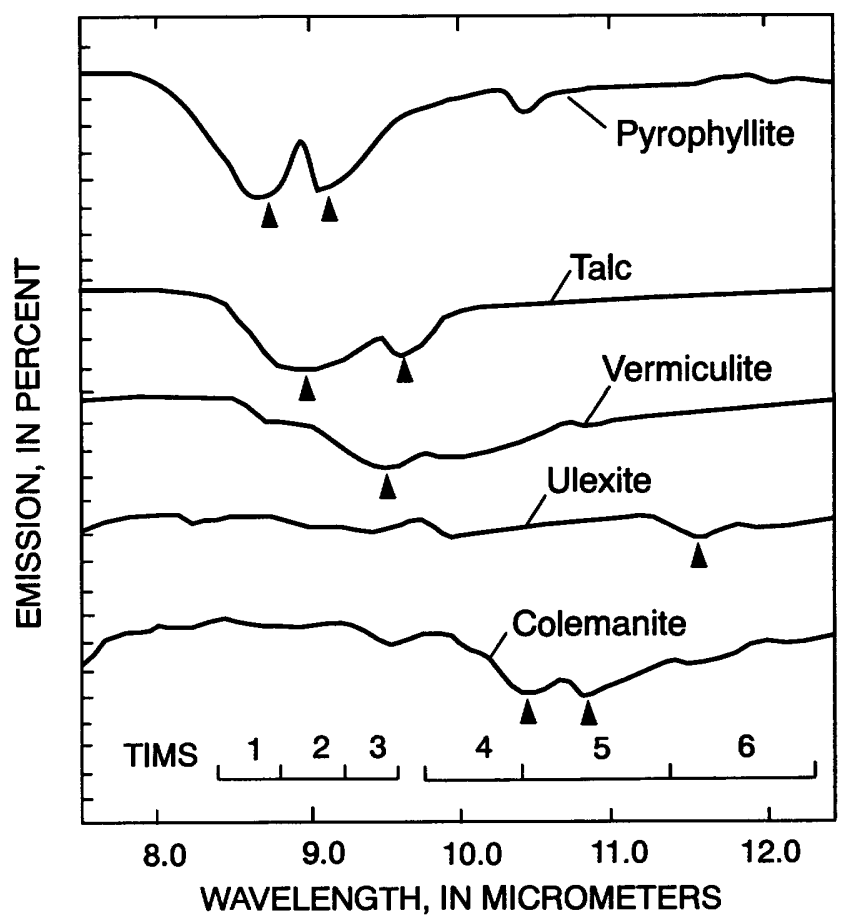

Figure 6. Thermal emission spectra of industrial minerals and ores. Spectra are offset vertically for viewing purposes, and TIMS (thermal-infrared multispectral scanner) bandpasses are shown on the lower part of the figure. Tickmarks on vertical axis indicate emission intervals of 5 percent. Arrows mark positions of diagnostic absorption features listed in table 2. Emission values of each spectrum at $12.5 \mu \mathrm{m}$ are (from top to bottom) 97 percent, 97 percent, 97 percent, 97 percent, and 95 percent.

pyrophyllite, talc, and vermiculite. TIR data appear to be well suited for detecting barite, phosphorite, perlite, quartz sand, and thenardite, none of which display diagnostic VNIR spectral features. Of course, such discrimination would depend on other factors besides the spectral properties of the minerals as measured in a laboratory setting. Chief among these factors is dilution and masking of the industrial mineral spectral signatures by vegetation, soil, and other rock materials. Because remote-sensing observations typically involve mixtures of these surface materials, spectral interpretation of remote-sensing data can be much more complex than laboratory spectral measurements might suggest. Another factor affecting the remote-sensing detection of surface exposures is the weathering stability of particular industrial minerals. Some minerals, such as talc and vermiculite, are relatively stable and may become concentrated in soils under moderate weathering conditions. On the other hand, evaporite minerals and volcanic glasses (e.g., perlite) tend to weather rapidly, which may degrade their spectral response. Even though laboratory spectral data are useful for developing remote-sensing strategies for discerning industrial minerals, working experience with particular mineral deposit types under a variety of terrain and weathering conditions is still needed. 


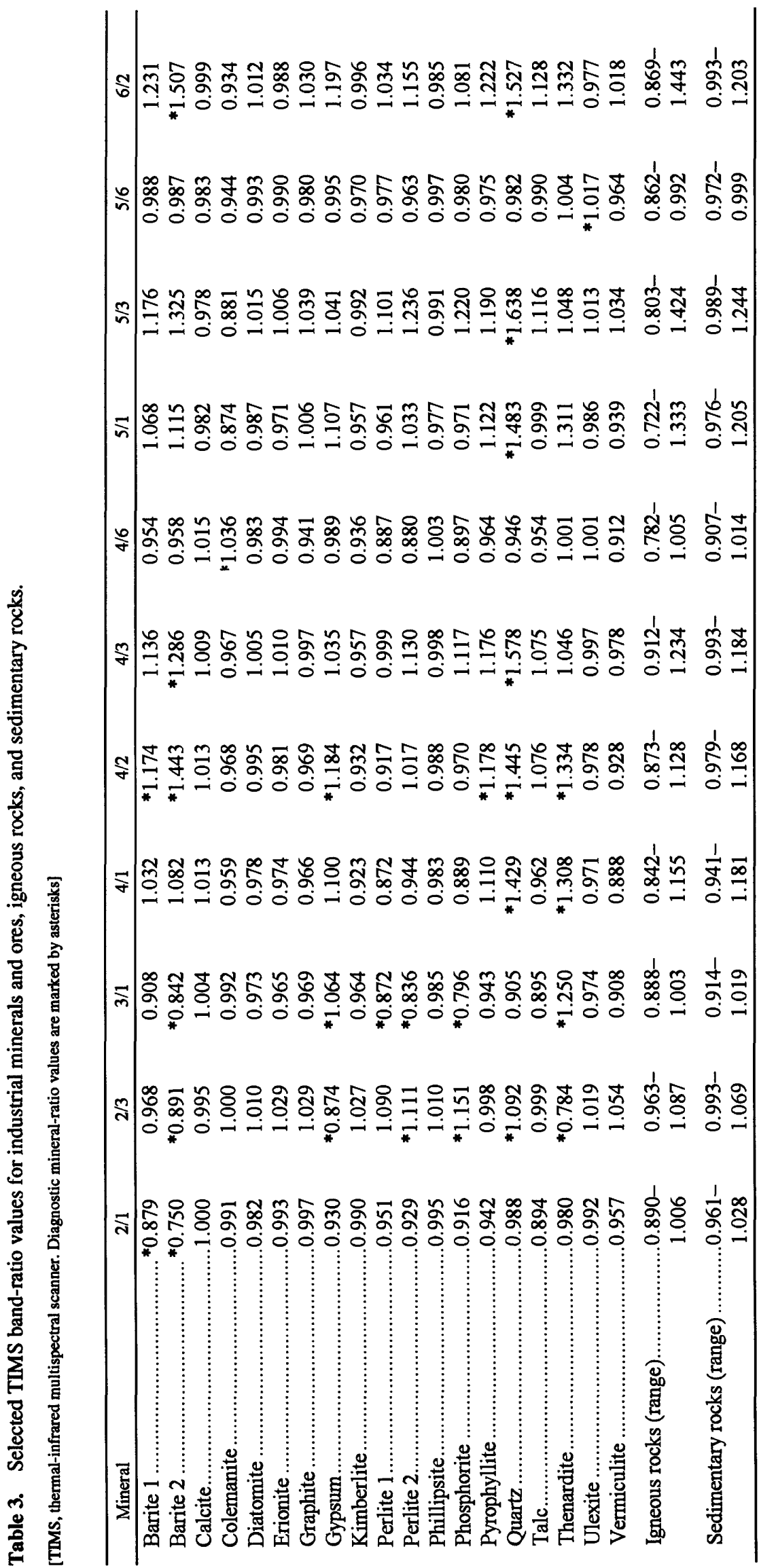


Sensor capabilities also have a determining role in the remote-sensing detection of industrial minerals. To identify minerals with VNIR data generally requires relatively high signal-to-noise and a narrow spectral sampling interval, such as the 11-15-nm interval of the 224-channel AVIRIS scanner (Vane and others, 1993). Passive thermal-infrared scanners, as a rule, have substantially fewer spectral bands, although there are plans to increase the number of bands beyond the six-band design of the current TIMS scanner (Kannari and others, 1992). Recently, an active TIR remotesensing system has been developed based on a rapidly tunable $\mathrm{CO}_{2}$ laser that provides much narrower TIR sampling intervals than passive scanner designs (Whitbourn and Hausknecht, 1990). Continued improvements in the signalto-noise and sampling intervals of both TIR and VNIR remote-sensing systems will enhance the ability to deconvolve spectral components present in mixtures of surface materials and, thus, should facilitate remote-sensing detection of industrial minerals.

\section{CONCLUSIONS}

This laboratory study demonstrates that many industrial minerals and ores exhibit VNIR and (or) TIR spectral features that might be useful for detecting the minerals with spectroscopic remote-sensing data. The two different wavelength ranges are complementary insofar as minerals that lack absorption bands in one range commonly exhibit features in the other. In practice, the remote-sensing detection of industrial minerals is likely to be affected by soil, rock, and vegetation mixtures, as well as by weathering processes. Accordingly, the next phase of this research will examine remote-sensing prospects for particular industrial minerals under actual field conditions.

\section{REFERENCES CITED}

Aines, R.D., and Rossman, G.R., 1984, Water in minerals? A peak in the infrared: Journal of Geophysical Research, v. 89, p. 4059-4071.

Bates, R.L., 1983, Introduction, in Lefond, S.J., ed., Industrial Minerals and Rocks, Volume 1: American Institute of Mining, Metallurgical, and Petroleum Engineers, Inc., 722 p.

Clark, R.N., King, T.V.V., Klejwa, M., and Swayze, G.A., 1990, High spectral resolution reflectance spectroscopy of minerals: Journal of Geophysical Research, v. 95, p. 12653-12680.

Crowley, J.K., 1991, Visible and near-infrared (0.4-2.5 $\mu \mathrm{m})$ reflectance spectra of playa evaporite minerals: Journal of Geophysical Research, v. 96, p. 16231-16240.

1993, Mapping playa evaporite minerals with AVIRIS data-A first report from Death Valley, California: Remote Sensing of Environment, v. 44, p. 337-356.
Crowley, J.K., Brickey, D.W., and Rowan, L.C., 1989, Airborne imaging spectrometer data of the Ruby Mountains, MontanaMineral discrimination using relative absorption band-depth images: Remote Sensing of Environment, v. 29, p. 121-134.

Crowley, J.K., Sherman, D.M., and Bennett, I.J., 1986, A low-cost digital recording and display system for Beckman UV 5200 series spectrophotometers: U.S. Geological Survey Open File Report 86-27, 23 p.

Ebel, P., Hauff, P., Hill, B., Nash, G., Ridd, M., and McGregor, L., 1993, Integrating remote sensing techniques (AVIRIS, TM, TIMS, and field spectroscopy) for exploration: Case historyCuprite, Nevada, in Proceedings of the Ninth Thematic Conference on Geologic Remote Sensing, Feb. 8-11, 1993, Pasadena: Ann Arbor, Environmental Research Institute of Michigan, v. 2, p. 833-843.

Farmer, V.C., ed., 1974, Infrared Spectra of Minerals: London, Adlard and Son, Ltd., Mineralogical Society of London, Monograph No. 4, $539 \mathrm{p}$.

Hunt, G.R., 1977, Spectral signatures of particulate minerals in the visible and near-infrared: Geophysics, v. 42, p. 501-513.

Hunt, G.R., and Salisbury, J.W., 1970, Visible and near-infrared spectra of minerals and rocks-I, Silicate minerals: Modern Geology, v. 1, p. 283-300

Hunt, G.R., Salisbury, J.W., and Lenhoff, C.J., 1972, Visible and near-infrared spectra of minerals and rocks- $V$, Halides, phosphates, arsenates, vanadates and borates: Modern Geology, v. 3, p. 121-134.

Kannari, Y., Mills, F., Watanabe, H., Ezaka, T., Narita, T., and Chang, S., 1992, Comparison of preliminary results from Airborne ASTER Simulator (AAS) with TIMS data, in Summaries of the Third Annual JPL Airborne Geoscience Workshop, June 1-5, 1992, v. 2: Jet Propulsion Laboratory Publication 92 14, p. 13-15.

Kingston, M.J., 1989, Spectral reflectance features of kimberlites and carbonatites-Implications for remote sensing for exploration, in Kimberlites and Related Rocks, v. 2, Proceedings of the Fourth International Kimberlite Conference, Perth, 1986: Geological Society of Australia Special Publication No. 14, p. 1135-1146.

Kingston, M.J., and Crowley, J.K., 1992, AVIRIS as a tool for carbonatite exploration-A comparison of SPAM and Mbandmap data analysis methods, in Summaries of the Third Annual JPL Airborne Geoscience Workshop, June 1-5, 1992, v. 1: Jet Propulsion Laboratory Publication 92-14, p. 116-118.

Lefond, S.J., ed., 1983, Industrial Minerals and Rocks: New York, American Institute of Mining, Metallurgical, and Petroleum Engineers, Inc., $1446 \mathrm{p}$.

Munts, S.R., Hauff, P.L., Seelos, A., McDonald, B., 1993, Reflectance spectroscopy of selected base-metal bearing tailings with implications for remote sensing, in Proceedings of the Ninth Thematic Conference on Geologic Remote Sensing, Feb. 8-11, 1993, Pasadena: Ann Arbor, Environmental Research Institute of Michigan, v. 1, p. 567-578.

Rowan, L.C., Kingston, M.J., Crowley, J.K., 1986, Spectral reflectance of carbonatites and related alkalic igneous rocks: Selected samples from four North American localities: Economic Geology, v. 81, p. 857-871. 
Salisbury, J.W., Walter, L.S. and D'Aria, D., 1988, Mid-infrared $(2.5-13.5 \mu \mathrm{m})$ spectra of igneous rocks: U.S. Geological Survey Open-File Report 88-686, 136 p.

Salisbury, J.W., Walter, L.S. Vergo, N., and D'Aria, D.M., 1991, Infrared (2.1-25 $\mu \mathrm{m})$ Spectra of Minerals: Baltimore, Johns Hopkins University Press, 267 p.

Vane, G., Green, R.O., Chrien, T.G., Enmark, H.T., Hansen, E.G., and Porter, W.M., 1993, The airborne visible/infrared imaging spectrometer (AVIRIS): Remote Sensing of Environment, v. 44, p. 127-143.

Whitbourn, L. B., and Hausknecht, P., 1990, Status of the CSIRO airborne $\mathrm{CO}_{2}$ laser active mid-IR remote sensing project, in Proceedings of the Fifth Australasian Remote Sensing Conference, Perth, October 8-12, 1990: Perth, Committee of the Fifth Australasian Remote Sensing Conference, Inc., v. 1, p. 391-398. 



\title{
CHAPTER G
}

\section{GEOCHEMICAL EXPLORATION STUDIES IN THE PORTUGUESE PYRITE BELT}

\author{
By David J. Grimes ${ }^{1}$ and Delfim de Carvalho ${ }^{2}$ \\ This report was prepared with the support and cooperation of the Luso \\ American Development Foundation, the Serviços Geológicos de \\ Portugal, and the Serviços de Formento Mineiro
}

\begin{abstract}
Geochemical exploration studies were conducted by the U.S. Geological Survey (USGS) and the Serviços Geológicos de Portugal (SGP) in the Portuguese Pyrite Belt (PPB) in southern Portugal during 1987 and 1988. Principal funding for this study was provided by the Luso American Development Foundation and was supplemented by funds from the USGS and the SGP.

The Portuguese Pyrite Belt is the part of the Iberian Pyrite Belt, which trends eastward from Seville, in southern Spain, across southern Portugal. The Iberian Pyrite Belt is about $230 \mathrm{~km}$ long and $30 \mathrm{~km}$ wide and is host to numerous copper-, zinc-, and lead-bearing massive sulfide deposits. The geology of this belt is structurally complex, and the rocks primarily consist of volcanic and sedimentary rocks of late Paleozoic age.

Rock, soil, plant, and water samples were collected near Neves-Corvo, in southern Portugal, where four, or more, clustered massive sulfide deposits, containing high amounts of copper, tin, and zinc and moderate amounts of several other metals, are covered by at least $200 \mathrm{~m}$ of sedimentary rock. In addition, a few plant and water samples were taken from other areas in the PPB where geological and geophysical conditions were considered favorable for massive sulfide deposits. The results of the geochemical surveys indicate that all of the methods tested may have application in the exploration for buried massive sulfide deposits.
\end{abstract}

\footnotetext{
${ }^{1}$ U.S. Geological Survey, P.O. Box 25046, Mail Stop 973, Denver Federal Center, Denver, CO 80225.

${ }^{2}$ Serviços Geológicos de Portugal, Lisbon, Portugal.
}

\section{INTRODUCTION}

Geochemical exploration studies were conducted at selected localities of the Portuguese Pyrite Belt (PPB) as part of a U.S. Geological Survey/Serviços Geológicos de Portugal cooperative program (fig. 1). These studies were designed to determine whether surface geochemical sampling methods combined with sensitive, multielement analytical techniques could be used to detect concealed massive sulfide deposits. A wide range of sample types, including rock, soil, vegetation, and water were collected and analyzed during these studies. Most of these samples were collected over the Neves-Corvo massive sulfide deposits (fig. 1).

\section{NEVES-CORVO STUDY AREA}

The Neves-Corvo area in southern Portugal was selected for these studies because it contains at least four large massive sulfide bodies that are buried by $200 \mathrm{~m}$ or more of weakly mineralized sedimentary and volcanic-sedimentary rocks. At the time of this study, the ground surface above the Neves-Corvo deposit was relatively undisturbed as compared to older mines in the PPB, and there was a lack of ore-treating and milling activities.

The Neves-Corvo study area is about $60 \mathrm{~km}$ south of the town of Beja and covers about $50 \mathrm{~km}^{2}$. The area has a gently rolling topography, and elevations range from about $170 \mathrm{~m}$ to $300 \mathrm{~m}$. According to "Baedeker's Portugal" (1986), the climate in this part of Portugal is influenced by both maritime and continental air masses. The average temperature for January is $8.2^{\circ} \mathrm{C}\left(46.8^{\circ} \mathrm{F}\right)$, and for August, $23^{\circ} \mathrm{C}\left(73.4^{\circ} \mathrm{F}\right)$. Average annual rainfall is $561 \mathrm{~mm}$ (22 in). The lowest monthly average is $2 \mathrm{~mm}$ in August, and the highest is 82 $\mathrm{mm}$ (3.2 in) in November. 


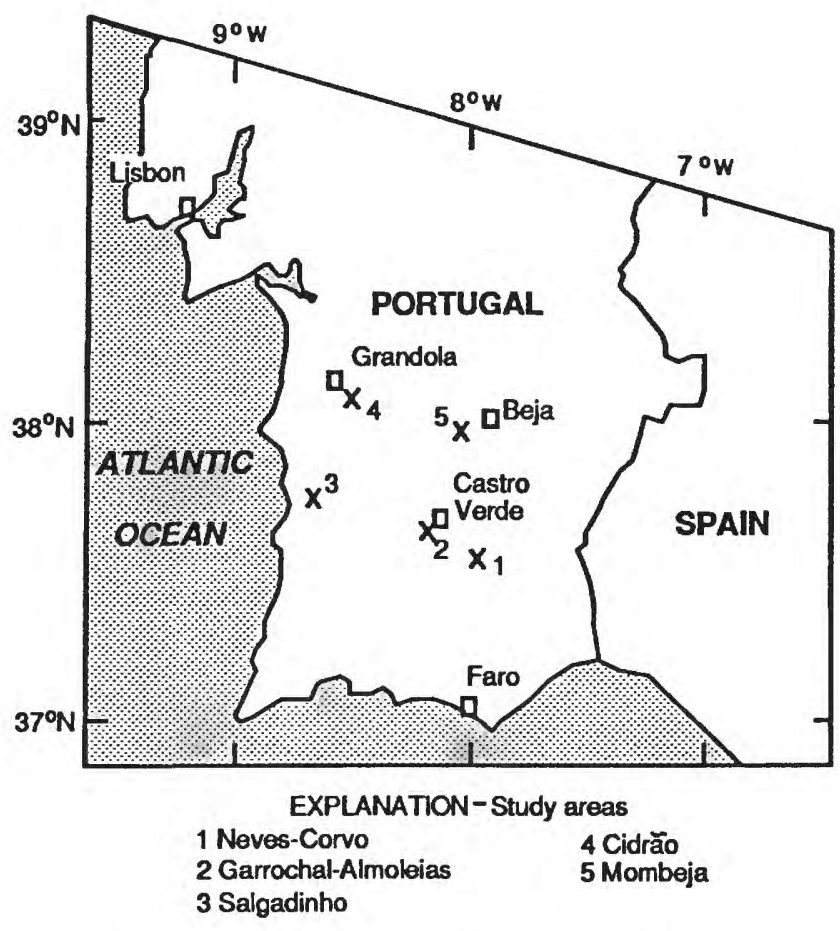

Figure 1. Index map of southern Portugal showing geochemical study areas (crosses). Names of study areas are shown in the explanation and are keyed to the map by number. Open squares indicate towns or cities.

\section{ORE DEPOSITS AND GEOLOGY}

The ore deposits at Neves-Corvo contain over 200 million tons of polymetallic massive sulfides with large reserves of high-grade copper and tin ores; the deposits are the most important supply of these metals in western Europe (Carvalho, 1991). Known reserves are in four clustered deposits called Neves, Corvo, Graça, and Zambujal (fig. 2). Other metals occurring with the ore in these deposits include lead, zinc, and minor amounts of arsenic, antimony, bismuth, indium, cadmium, cobalt, selenium, silver, and gold.

The massive sulfide bodies in the Neves-Corvo area are syngenetic volcanogenic stratabound deposits that are associated with the culmination of felsic volcanism. The deposits are underlain by felsic volcanic rocks and overlain by sedimentary and volcanic-sedimentary rocks. The volcanic and volcanic-sedimentary rocks make up the Volcanic Siliceous Complex (VS), which comprise the host rocks for massive sulfide deposits throughout the Portuguese and Spanish parts of the Iberian Pyrite Belt (Schermerhorn, 1970; Carvalho and others, 1976). In the Neves-Corvo area, as in other parts of the PPB, the VS is overlain by the Culm Group, a flysch sequence of rocks that consists mostly of monotonous, cyclic sequences of graywacke and shale. Although the stratigraphic sequence in the Neves-Corvo area contains some differences as compared to other massive sulfide localities in the PPB, as discussed by Carvalho (1991), the lithologic similarities suggest that geochemical exploration methods developed in the Neves-Corvo area would be applicable to other parts of the Iberian Pyrite Belt and perhaps to other similar metallogenic provinces.

\section{GEOCHEMICAL STUDY-ROCK AND SOIL LEACHATES}

Ore and related elements that are released from primary and secondary minerals by chemical reactions and weathering processes may move in solution from buried deposits to the surface environment along hydrologic pathways, such as open pores, joints, bedding planes, fractures, and faults. At the surface, the mobilized metals may precipitate or be removed from solution at reaction sites on clay, organic material, carbonates, manganese oxides, iron oxides, and secondary sulfides. In exploration geochemistry it is important to determine the distribution of these pathfinder metals in various chemical phases in order to select the optimum dissolution technique to be used in an analytical procedure. This knowledge of the partitioning of ore-associated elements allows dissolution and analysis of only that sample fraction that contains the highest concentration of these elements. Selective dissolution often provides a greater geochemical contrast between anomalous and background values than does total dissolution. The use of partial-dissolution techniques has been shown to enhance geochemical anomalies in soils and sediments (see Bradshaw and others, 1974; Chao and Theobald, 1976) and in rocks and joint coatings (Crone and others, 1984; Filipek and Theobald, 1981).

The geochemical study in the Neves-Corvo area was designed to determine if ore-associated metals were partitioned into one or more chemical phases in rocks and soils above and around the massive sulfide bodies and if this information could be used to delineate the location of the buried mineral deposit.

\section{SAMPLE COLLECTION, PREPARATION, AND ANALYSIS}

In July of 1987, rock and soil samples were collected along northeast to southwest traverses in the Neves-Corvo area (figs. 2 and 3 ). Traverse lines were perpendicular to the trend of the local, dominant, plunging anticline, the central part of which comprises the Volcanic Siliceous Complex, the host formation of the massive sulfide ore deposits. The lines were located approximately $0.5 \mathrm{~km}$ apart, where practical, and the rock and soil sample sites were spaced at intervals of about $0.5 \mathrm{~km}$. Soil samples were collected at depths of $20 \mathrm{~cm}$, air dried in the field, and then sieved to minus -80 mesh $(0.17 \mathrm{~mm})$ in the laboratory. Rock samples containing visible iron or manganese oxide or other signs of alteration in the matrix, as coatings, or along fractures were collected at most sites. These were crushed to approximately minus- 6 $\mathrm{mm}$ in a jaw crusher and split with a riffle-type splitter. A 


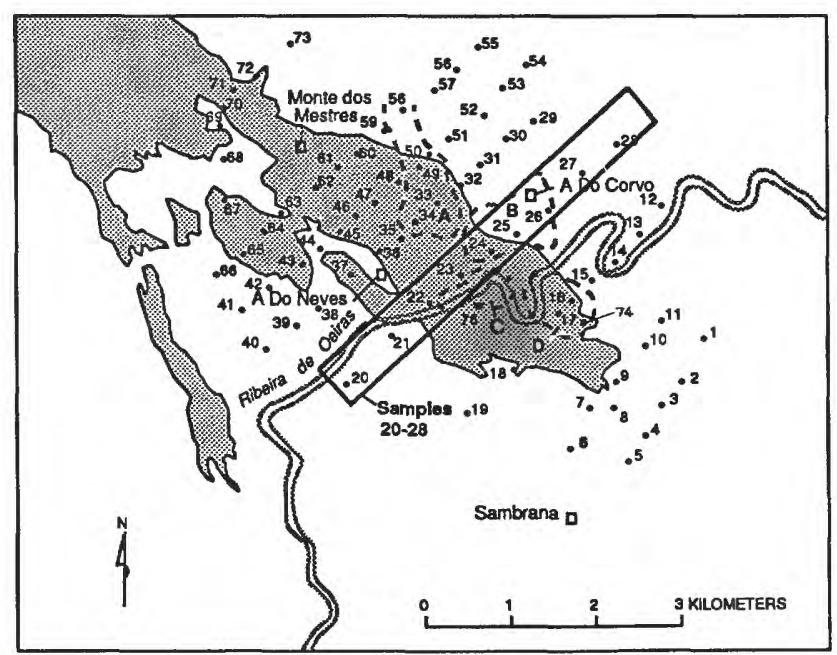

EXPLANATION

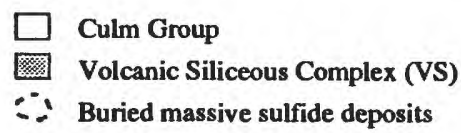
A Neves
B Corvo
C Graça
D Zambujal

Figure 2. Rock sample localities, Neves-Corvo area, southern Portugal. Numbers indicate sites at which rock samples were collected; letters A-D indicate ore deposits; open squares indicate towns.

representative split was then ground to about $0.1 \mathrm{~mm}$ in a vertical pulverizer equipped with ceramic plates.

Rock and soil samples collected along the traverse containing samples 20-28 (figs. 2 and 3 ) were initially subjected to a four-step sequential dissolution scheme modified from a procedure described by Chao (1984). This scheme was designed to solubilize and separate chemical phases of the samples in the following order: (1) Mn-oxides and amorphous Fe-oxides, (2) crystalline Fe-oxides, (3) sulfides and organics, and (4) the residue ("silicate fraction"). The procedure for this four-step sequential dissolution technique is provided in Appendix 1 of this report. A separate total digestion was performed on each of these samples with a fresh 0.5 -g sample split using the same procedure as in step 4, Appendix 1.

Each chemical phase from the sequential dissolution procedure was analyzed for 18 elements at USGS laboratories in Denver, Colo., using induction coupled plasmaatomic emission spectrometry (ICP-AES) with operating parameters described by Motooka and Sutley (1982). Several of the rock samples on the traverse with samples 20-28 were also analyzed by $\mathrm{X}$-ray diffraction to determine the mineralogy of the fracture and surface coatings.

\section{RESULTS OF SEQUENTIAL DISSOLUTION STUDY}

The results of the sequential dissolution and analysis of rock and soil samples from the test traverse are summarized

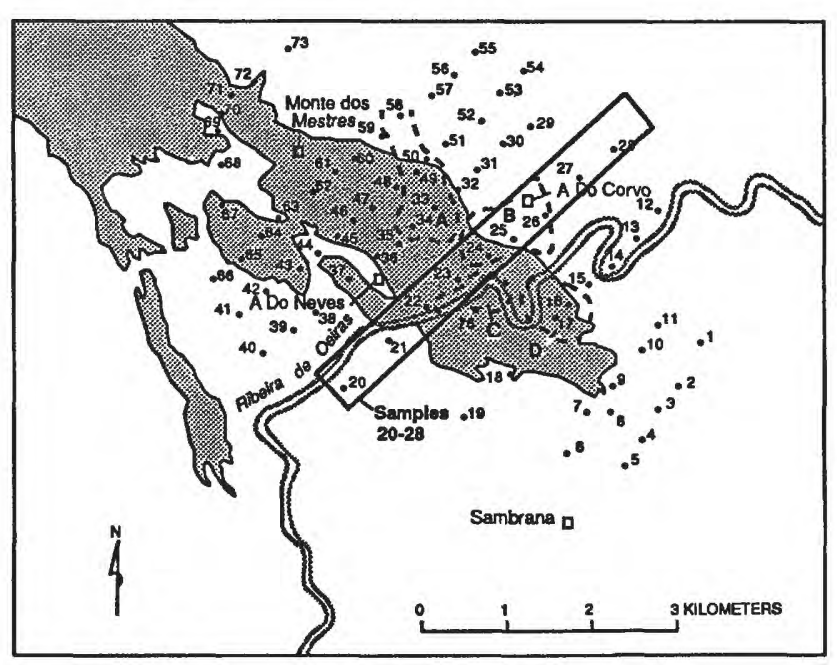

EXPLANATION
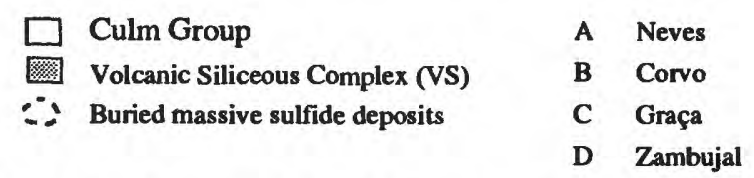

Figure 3. Soil sample localities, Neves-Corvo area, southern Portugal. Numbers indicate sites at which soil samples were collected; letters A-D indicate ore deposits; open squares indicate towns

for selected elements in Appendixes 2 and 3. Analytical results of total digestions for the rock and soil samples are not listed in these appendixes, but the total concentrations were generally within 10 percent of the sum of the concentrations of steps $1-4$, indicating no significant systematic errors due to any of the sequential dissolution steps. In both sample types, arsenic, iron, molybdenum, and zinc are selectively partitioned in the crystalline $\mathrm{Fe}$-oxide fraction (Feox), copper and manganese in the Fe-ox and Mn-oxideamorphous Fe-oxide fractions, sodium primarily in the residue (silicate) fraction, and lead is partitioned into all of the above fractions at different sample sites. Arsenic, copper, and molybdenum show, in most cases, enhanced concentrations in the Fe-ox fraction for both rock and soil samples at sites $22,23,24$, and 25 , all of which are above or very close to the vertical projection to the surface of several of the buried massive sulfide bodies. Iron and zinc, even though selectively partitioned in the Fe-ox fractions, do not show the same degree of enhancement over the ore deposit as do arsenic, copper, and molybdenum. In fact, zinc concentrations for rock and soil samples from sites 22 and 23 indicate a depletion relative to the respective geometric means for zinc (tables 1 and 2). Manganese and lead show no pattern of enrichment over the deposit in either sample type, and sodium is selectively partitioned into the residual fraction, probably reflecting the occurrence of this element in the structure of aluminosilicate minerals.

$\mathrm{X}$-ray diffraction analysis of coatings from several rock samples along the traverse for samples $20-28$ confirms that 
Table 1. Statistical summary of chemical analyses for $4 \mathrm{~N} \mathrm{HCl}$ leachates of 80 rock samples, Neves-Corvo area, southern Portugal.

\begin{tabular}{|c|c|c|c|c|c|}
\hline Variable & Minimum & Maximum & $\begin{array}{c}\text { Geometric } \\
\text { mean }\end{array}$ & $\begin{array}{l}\text { Geometric } \\
\text { deviation }\end{array}$ & $\begin{array}{c}\text { 75th } \\
\text { percentile }\end{array}$ \\
\hline As (ppm) & $<0.3$ & 270 & 10 & 3.1 & 13 \\
\hline $\mathrm{Ba}(\mathrm{ppm})$ & 3.3 & 300 & 31 & 2.2 & 44 \\
\hline $\mathrm{Ca}(\%)$ & 0.004 & 0.86 & 0.051 & 2.6 & 0.10 \\
\hline $\mathrm{Co}(\mathrm{ppm})$ & 0.7 & 40 & 6.5 & 2.7 & 12 \\
\hline $\mathrm{Cr}(\mathrm{ppm})$ & 1 & 47 & 15 & 2.6 & 30 \\
\hline $\mathrm{Cu}(\mathrm{ppm})$ & 3 & 920 & 29 & 3.1 & 62 \\
\hline $\mathrm{Fe}(\%)$ & 0.3 & 13 & 3.5 & 2.0 & 4.6 \\
\hline $\mathrm{K}(\mathrm{ppm})$ & 28 & 1,800 & 420 & 2.2 & 700 \\
\hline $\mathrm{Mg}(\%)$ & 0.003 & 1.1 & 0.24 & 4.8 & 0.75 \\
\hline $\mathrm{Mn}(\%)$ & 0.003 & 0.71 & 0.063 & 2.8 & 0.10 \\
\hline Mo (ppm) & $<1$ & 50 & 1.4 & 3.6 & 2.0 \\
\hline $\mathrm{Na}(\mathrm{ppm})$ & 34 & 560 & 97 & 1.7 & 120 \\
\hline $\mathrm{Ni}(\mathrm{ppm})$ & 1.8 & 140 & 25 & 2.0 & 32 \\
\hline $\mathrm{P}(\mathrm{ppm})$ & 10 & 1,600 & 130 & 3.4 & 320 \\
\hline $\mathrm{Pb}(\mathrm{ppm})$ & $<5$ & 260 & 15 & 2.8 & 22 \\
\hline $\mathrm{Sr}(\mathrm{ppm})$ & 0.51 & 47 & 5.7 & 2.0 & 7.7 \\
\hline Ti (ppm) & 2.3 & 120 & 15 & 1.9 & 21 \\
\hline $\mathrm{Zn}(\mathrm{ppm})$ & 2 & 220 & 39 & 2.2 & 61 \\
\hline
\end{tabular}

most of the iron present in the coatings is crystalline, with goethite ( $80-90$ percent) and hematite (10-20 percent) identified as the principal iron-oxide minerals.

The results of the sequential dissolution study at NevesCorvo indicate that several ore-associated metals, such as arsenic, copper, and molybdenum, are selectively partitioned into the crystalline iron-oxide and manganese-oxide fractions of rock and soil samples and that analysis of these combined fractions may provide a high contrast between anomalous and background values. Thus, the chemical dissolution used for the 80 rock and 74 soil samples collected in the Neves-Corvo study area was that used in step 2, Appendix 1 , of the sequential dissolution scheme. This dissolution solubilizes both the $\mathrm{Fe}$-ox and the $\mathrm{Mn}$-oxide-amorphous $\mathrm{Fe}$ oxide fractions and is hereafter designated as the $4 \mathrm{~N} \mathrm{HCl}$ leachate fraction.

\section{RESULTS OF ANALYSIS OF $4 \boldsymbol{N}$ HCL LEACHATES}

Statistical summaries for selected elements from the ICP-AES analyses of $4 \mathrm{~N} \mathrm{HCl}$ leachates of rock and soil samples collected in the Neves-Corvo area are listed in tables 1 and 2. Other elements, such as antimony, bismuth, and tin, were detected in only a few samples and therefore are not listed. Concentration ranges for most of the elements listed in the tables fall within the analytical determination limits of the method used; however, some elements for several samples were reported as not detected at the lower limit of determination. For statistical computations, these qualified values were arbitrarily replaced with real values equal to 0.7 times the lower determination limit, as described by Miesch (1976). Univariate analysis of these data was used to obtain basic element-distribution information. Inspection of frequency-distribution histograms and the general agreement between the median and geometric mean for most of the elements indicated lognormal distribution of the data. Cumulative frequency diagrams helped determine the threshold value between anomalous and background populations for each element. Where bimodal or mixed populations were found by this method, the threshold value commonly occurred between the 70th and 80th percentiles. Consequently, element threshold values were selected to be those concentrations at the 75th percentile as given in tables 1 and 2. Trace-element concentrations at and above these threshold values are considered to be anomalous.

Trace-element-distribution maps for copper, arsenic, and molybdenum in $4 \mathrm{~N} \mathrm{HCl}$ leachates of rock samples are shown in figures 4,5 , and 6 , and distribution maps for copper, lead, arsenic, and molybdenum in $4 \mathrm{~N} \mathrm{HCl}$ leachates of soil samples are shown in figures 7,8,9, and 10 .

Copper.-Anomalous amounts of copper were found in samples clustered in an area northwest of the town of A Do Neves (figs. 4 and 7). This anomaly may be related to surface and near-surface mineralized chert and sulfidebearing manganese occurrences, which are locally present. Other samples containing anomalous amounts of copper include rock and soil samples over the Graça and Zambujal ore bodies and samples from an area near a known nearsurface sulfide deposit northwest of the town of Monte dos Mestres. 
Table 2. Statistical summary of chemical analyses for $4 \mathrm{NHCl}$ leachates of 74 soil samples, NevesCorvo area, southern Portugal.

[Values preceded by "<"indicate that the element was not detected at the lower limit of determination shown; these values were replaced with values equal to seven-tenths of the lower determination limit (Miesch, 1976) in determining geometric means and geometric deviations]

\begin{tabular}{lccccc}
\hline Variable & Minimum & Maximum & $\begin{array}{c}\text { Geometric } \\
\text { mean }\end{array}$ & $\begin{array}{c}\text { Geometric } \\
\text { deviation }\end{array}$ & $\begin{array}{c}\mathbf{7 5 \text { th }} \\
\text { percentile }\end{array}$ \\
\hline $\mathrm{As}(\mathrm{ppm})$ & 4 & 55 & 12 & 1.9 & 19 \\
$\mathrm{Ba}(\mathrm{ppm})$ & 23 & 320 & 48 & 1.6 & 56 \\
$\mathrm{Ca}(\%)$ & 0.023 & 2.5 & 0.13 & 2.4 & 0.22 \\
$\mathrm{Co}(\mathrm{ppm})$ & 2.5 & 31 & 11 & 1.5 & 14 \\
$\mathrm{Cr}(\mathrm{ppm})$ & 5.3 & 28 & 15 & 1.5 & 20 \\
$\mathrm{Cu}(\mathrm{ppm})$ & 6 & 140 & 27 & 2.1 & 52 \\
$\mathrm{Fe}(\%)$ & 1.5 & 4 & 2.6 & 1.3 & 3.0 \\
$\mathrm{~K}(\mathrm{ppm})$ & 180 & 2,000 & 580 & 1.9 & 950 \\
$\mathrm{Mg}(\%)$ & 0.032 & 0.74 & 0.27 & 2.0 & 0.44 \\
$\mathrm{Mn}(\%)$ & 0.019 & 0.43 & 0.098 & 2.1 & 0.20 \\
$\mathrm{Mo}(\mathrm{ppm})$ & $<1$ & 11 & 1.1 & 2.2 & 2.0 \\
$\mathrm{Na}(\mathrm{ppm})$ & 55 & 340 & 97 & 1.5 & 110 \\
$\mathrm{Ni}(\mathrm{ppm})$ & 5.8 & 48 & 22 & 1.4 & 27 \\
$\mathrm{P}(\mathrm{ppm})$ & 110 & 810 & 290 & 1.5 & 350 \\
$\mathrm{~Pb}(\mathrm{ppm})$ & 7 & 110 & 18 & 1.6 & 22 \\
$\mathrm{Sr}(\mathrm{ppm})$ & 3.1 & 120 & 11 & 1.9 & 16 \\
$\mathrm{Ti}(\mathrm{ppm})$ & 16 & 87 & 30 & 1.4 & 35 \\
$\mathrm{Zn}(\mathrm{ppm})$ & $<5$ & 110 & 36 & 1.6 & 44 \\
\hline
\end{tabular}

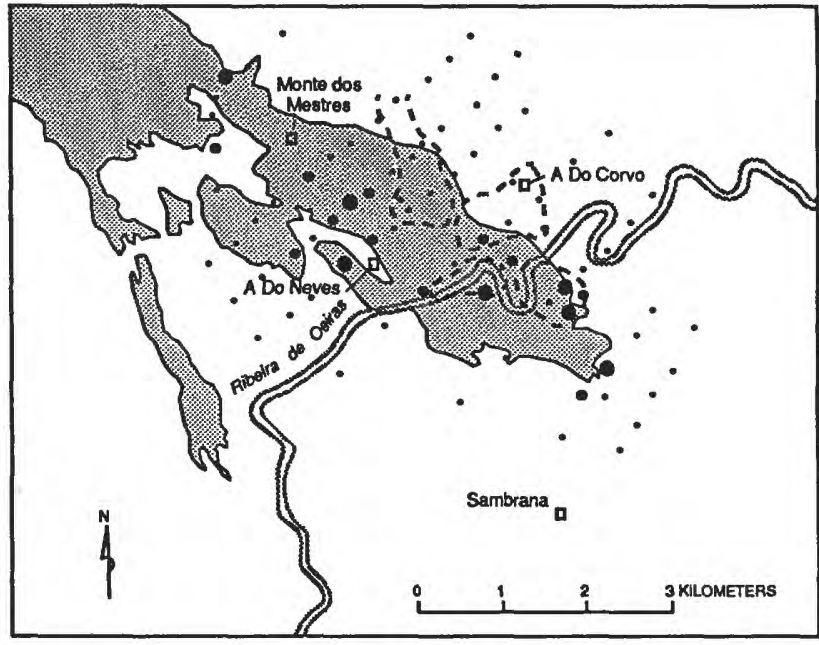

EXPLANATION

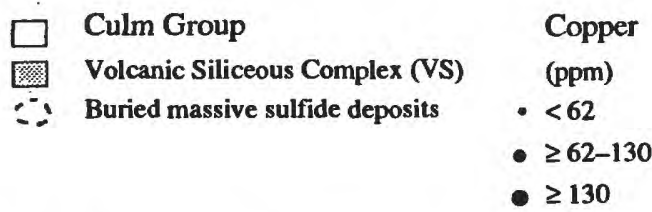

Figure 4. Distribution of copper in rock leachates $(4 \mathrm{~N} \mathrm{HCl})$, Neves-Corvo area, southern Portugal. Open squares indicate towns.

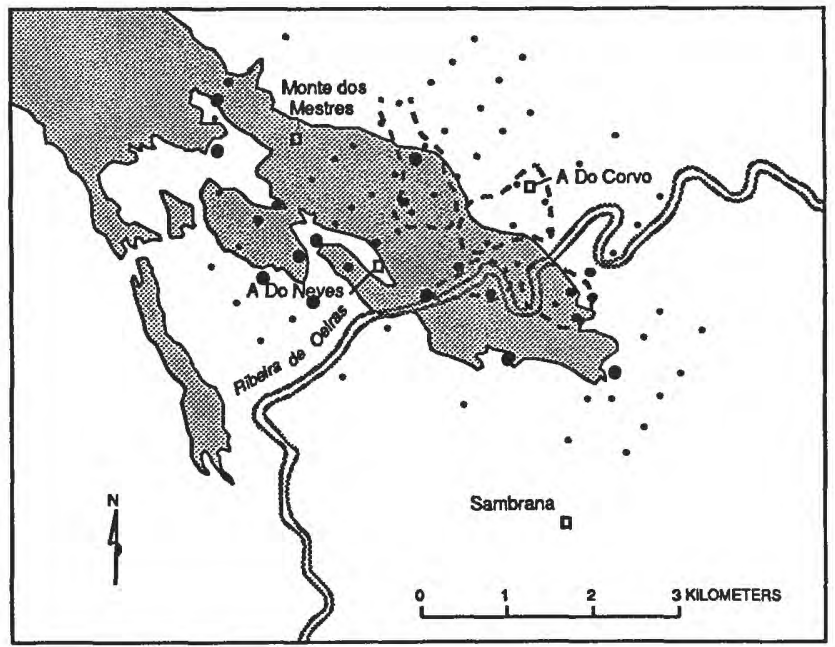

EXPLANATION

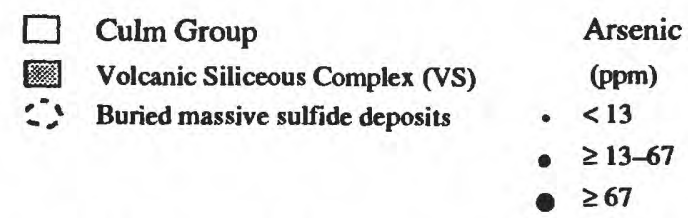

Figure 5. Distribution of arsenic in rock leachates $(4 N \mathrm{HCl})$, Neves-Corvo area, southern Portugal. Open squares indicate towns. 


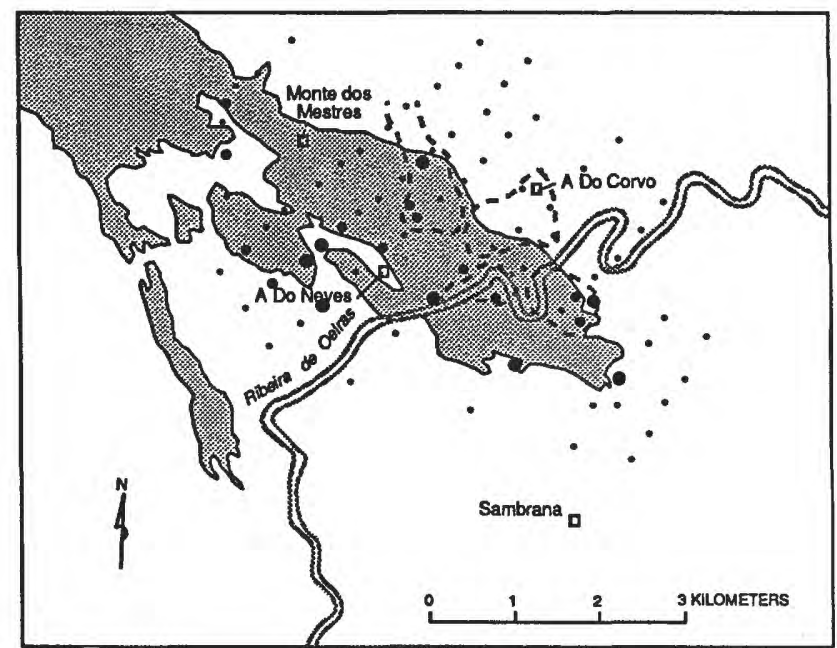

\section{EXPLANATION}

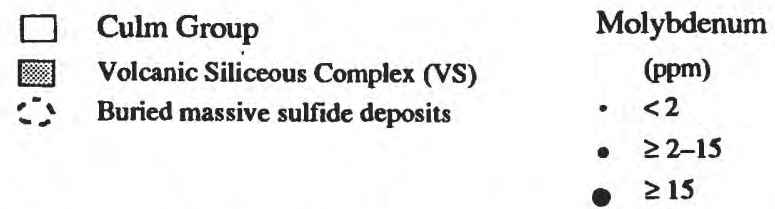

Figure 6. Distribution of molybdenum in rock leachates (4 N $\mathrm{HCl}$ ), Neves-Corvo area, southern Portugal. Open squares indicate towns.

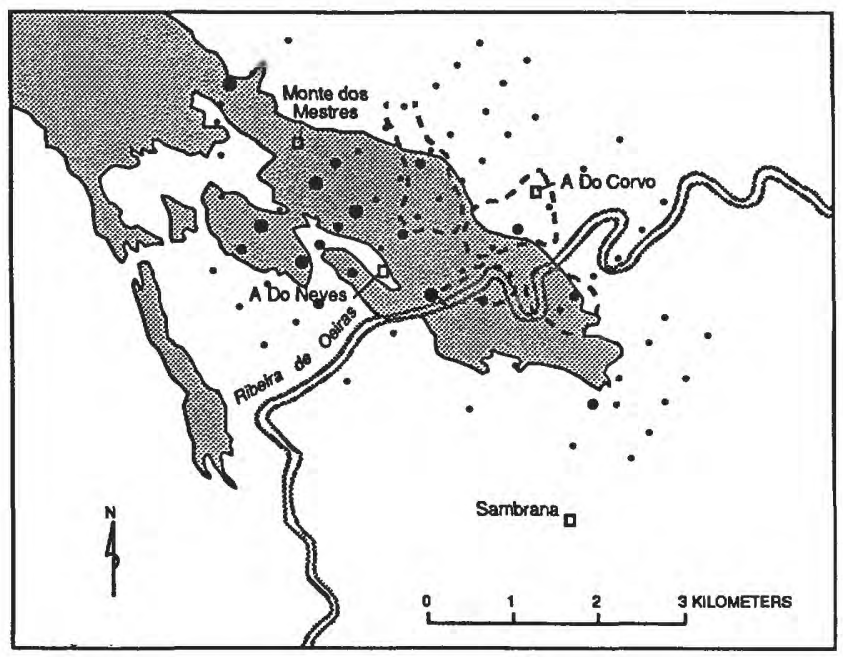

EXPLANATION

$\begin{array}{lll}\square & \text { Culm Group } & \text { Copper } \\ \square & \text { Volcanic Siliceous Complex (VS) } & (\mathrm{ppm}) \\ \because \quad \text { Buried massive sulfide deposits } & <52 \\ & & \bullet \geq 52-69 \\ & & \bullet 69\end{array}$

Figure 7. Distribution of copper in soil leachates $(4 \mathrm{~N} \mathrm{HCl})$, Neves-Corvo area, southern Portugal. Open squares indicate towns.

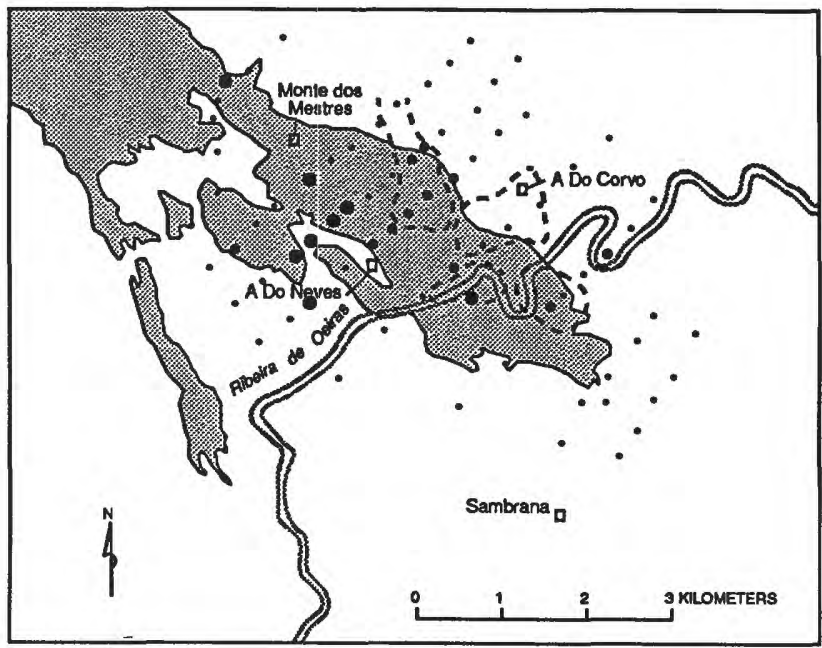

\section{EXPLANATION}

$\begin{array}{lll}\square \text { Culm Group } & \text { Lead } \\ \square \text { Volcanic Siliceous Complex (VS) } & \text { (ppm) } \\ \therefore \text { Buried massive sulfide deposits } & \cdot<22 \\ & & 022-32 \\ & & \geq 32\end{array}$

Figure 8. Distribution of lead in soil leachates $(4 N \mathrm{HCl})$, Neves-Corvo area, southern Portugal. Open squares indicate towns.

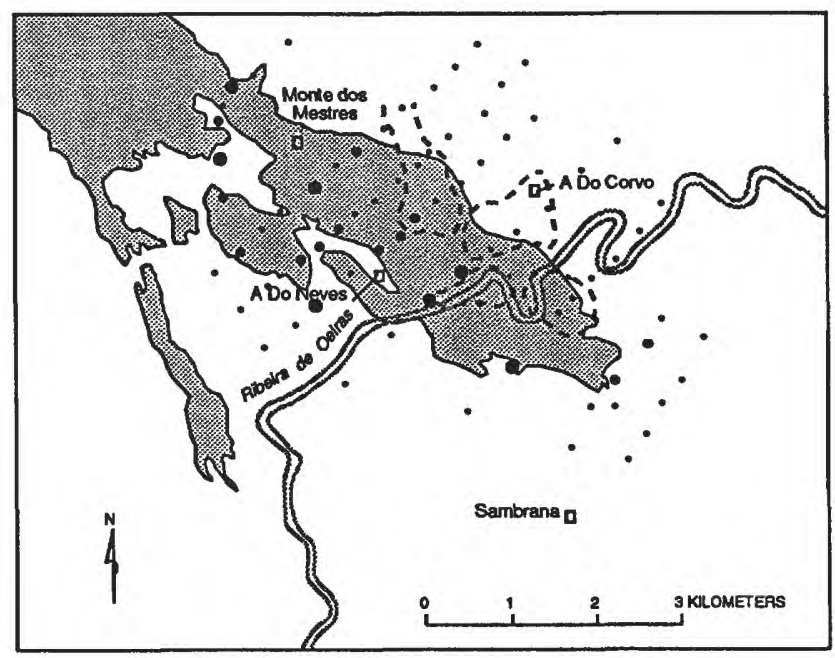

\section{EXPLANATION}

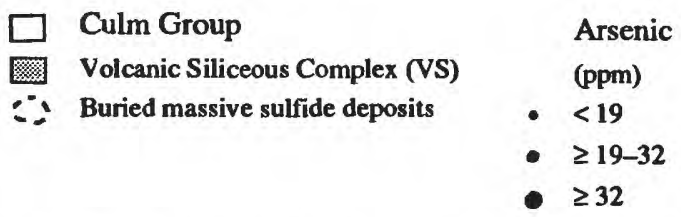

Figure 9. Distribution of arsenic in soil leachates $(4 \mathrm{~N} \mathrm{HCl})$, Neves-Corvo area, southern Portugal. Open squares indicate towns. 


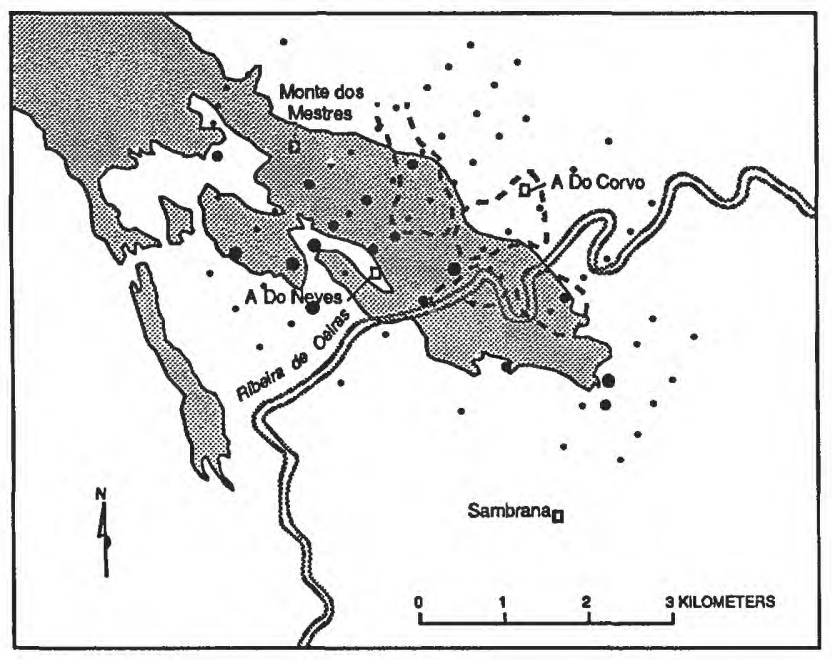

EXPLANATION

$\begin{array}{llc}\square & \text { Culm Group } & \text { Molybdenum } \\ \text { Volcanic Siliceous Complex (VS) } & \text { (ppm) } \\ \because \text { Buried massive sulfide deposits } & -<2 \\ & & \bullet \geq 2-5 \\ & -\geq 5\end{array}$

Figure 10. Distribution of molybdenum in soil leachates (4 N $\mathrm{HCl}$ ), Neves-Corvo area, southern Portugal. Open squares indicate towns.

Lead.-Soil leachates contain anomalous amounts of lead over the Graça orebody, over the southern part of the Neves orebody, and northwest of A Do Neves (fig. 8).

Arsenic-Figures 5 and 9 show that elevated levels of arsenic are present in the leachates northwest of A Do Neves, near a known near-surface sulfide deposit northwest of the town of Monte dos Mestres, and over the Graça orebody.

Molybdenum.-High concentrations of molybdenum (figs. 6 and 10) also delineate anomalous areas northwest of A Do Neves and adjacent to the Graça orebody.

Other elements.-Anomalous patterns for zinc were not found in rock and soil leachates; however, high zinc concentrations were found at scattered locations, such as at sample sites 71 (220 ppm in rock; $110 \mathrm{ppm}$ in soil), 47 (160 ppm in rock), and 34 ( $83 \mathrm{ppm}$ in soil). Antimony was detected in samples at sites 62 (36 ppm in rock; $8 \mathrm{ppm}$ in soil), 42 (25 ppm in rock), 70 (15 ppm in rock), and 22 (13 ppm in rock). Also, a rock sample collected at site 62 contained 7 ppm silver in the $4 \mathrm{~N} \mathrm{HCl}$ leachate fraction.

\section{SUMMARY OF LEACHATE STUDY}

Analytical results of the selective leaching of crystalline Fe-oxide and Mn-oxide-amorphous Fe-oxide fractions of rocks and soils in the Neves-Corvo study area appear to delineate anomalies spatially associated with a known nearsurface sulfide deposit, Cerro do Algare, northwest of the town of Monte dos Mestres, and results also appear to delineate the concealed Graça and Zambujal massive sulfide bodies. An anomalous area northwest of the town of A Do Neves, probably related to nearby mineralized chert and sulfide-bearing manganese occurrences, but possibly related to unknown buried sulfide deposits, was also defined. Both sample media indicated similar element-distribution patterns; however, the anomalies appear to be more intense in rock leachates as compared to soil leachates, especially for arsenic, copper, and molybdenum. All of these anomalies occur within the boundaries of the Volcanic Siliceous Complex, and they may indicate lithologies favorable for massive sulfide deposits rather than delineating the deposits themselves.

Significant anomalies were not found over the deeper massive sulfide bodies of Neves and Corvo, particularly in those areas of outcropping shales and graywackes of the Culm Group. The lack of anomalies in these areas suggests that leachates may be most useful in the PPB for exploration for near-surface mineral deposits or in defining lithologies favorable for hosting massive sulfide deposits.

\section{BIOGEOCHEMICAL STUDY}

The use of biogeochemistry-the collection and analysis of vegetation-in the search for concealed ore deposits has been successfully applied as an exploration tool in many countries. The basic principles of biogeochemical prospecting and applications in various geological environments are discussed in detail by Levinson (1974), Brooks (1972), and Kovalevskii (1974). The biogeochemical study in the NevesCorvo area was designed to determine if analysis of surface vegetation would reflect the presence of buried massive sulfide bodies, and, if so, could this method be applied to other areas in the PPB in exploration for similar hidden ore deposits. This investigation, to our knowledge, is the first biogeochemical exploration study to be undertaken in the PPB.

The vegetation found in the Neves-Corvo study area is predominated by evergreens, most of which are Holm oak with a lesser amount of Cork oak. The Holm oak (Quercus ilex) was described by Humphries and others (1985) as a broadly domed evergreen tree as much as $25 \mathrm{~m}$ high with brownish-black bark cracked into shallow, square plates. The Cork oak (Quercus suber) was described as an evergreen tree as much as $20 \mathrm{~m}$ high with thick and corky bark that forms sinuous interconnecting ridges and is pale grayish-brown in color but reveals a smooth and red-brown trunk where the bark has been stripped. The undergrowth in the study area is covered by grasses and aromatic herbs and shrubs such as Esteva cistus. The oak, or azinheira, was selected for the biogeochemical investigation because of its widespread distribution in this area and in other parts of the PPB and also because of its deep root system, which gives this tree the potential for accumulating ore-associated 
elements from deep below the ground surface. An example of the use of biogeochemical analysis of the twigs and leaves of oak trees to detect buried mineral deposits in the Appalachian Piedmont in Virginia was documented by Leavitt and Goodell (1979).

\section{SAMPLE COLLECTION, PREPARATION, AND ANALYSIS}

In July of 1987, samples of Holm oak trees (Quercus ilex) were collected at most of the soil sample localities along the same traverse lines previously described (fig. 3). At each oak tree sample site, the first-year growth (new leaves and stems), older stems (2- to 5-year growth), and, where available, the new acorns were collected. Tree loppers and hand pruners were used to collect composite samples from around the perimeter of individual trees. An attempt was made to sample trees of similar size and most vigorous growth. At several sites, samples were taken from individual Holm oak trees with trunk diameters ranging from 10 to 50 $\mathrm{cm}$, as measured from a point $1 \mathrm{~m}$ above ground level, to determine the influence of tree size on trace-element content. Trees from three sample sites were resampled in August, November, and December of 1987 to determine the effects of seasonal variation on trace-element concentrations. No Cork oak trees (Quercus suber) were found growing in the vicinity of the buried ore deposit; however, several Cork oaks were sampled near sample site 2 (fig. 3 ) for the purpose of comparing its biogeochemical response to that of Holm oak. In addition to samples of oak trees, samples of leaves and stems of Esteva cistus were collected at many of the same sample sites.

The plant samples were stored in cloth bags and air dried in the field. In the laboratory, the samples were washed with deionized water, dried in an oven at $35^{\circ} \mathrm{C}$ for 24 hours, ground in a Wiley mill, ashed in a muffle furnace at $450^{\circ} \mathrm{C}$ for $\mathbf{8}$ hours, and homogenized in a shaker.

In the vegetation-digestion procedure, $3 \mathrm{~mL}$ of concentrated $\mathrm{HCl}$ was added to a centrifuge tube containing $0.36 \mathrm{~g}$ of plant ash. One $\mathrm{mL}$ of hydrogen peroxide was then added and the mixture was left to stand for 1 hour. The solutions were then heated in a water bath at $95^{\circ} \mathrm{C}$ for 20 minutes, cooled, and diluted with $5 \mathrm{~mL}$ of deionized water to give 4 $M \mathrm{HCl}$ solutions with a dilution factor of 1:25. Finally, the sample solutions were agitated, centrifuged, and decanted.

Each solution was analyzed for 17 elements at USGS laboratories in Denver, Colo., using ICP-AES with operating parameters described by Motooka and Sutley (1982). Some of the plant samples collected along the traverse for samples 20-28 (fig. 3) were also analyzed for several additional elements, including antimony, bismuth, indium, and tin, employing a very sensitive inductively coupled plasmamass spectrographic (ICP-MS) technique (Lichte and others, 1987) using the same sample solutions as described above.
For this technique, cadmium was added to each sample solution as an internal standard to correct for sample matrix variation and instrumental fluctuations. The sample solutions were then analyzed directly using a Sciex Elan model 250 ICP-MS system and compared to calibration standards which contained $100 \mu \mathrm{g} / \mathrm{L}$ of the elements of interest. All samples and standards were corrected for background matrix effects and blank effects.

\section{RESULTS OF BIOGEOCHEMICAL STUDY}

Preliminary evaluation of the analytical data from vegetation collected over the buried massive sulfide deposit at Neves-Corvo indicated a biogeochemical response for several ore-associated elements. The most favorable anomalyto-background ratios were found in parts of the Holm oak tree, which contained relatively high amounts of arsenic and copper. The first-year growth (leaves and stems) of the Holm oak contained the highest concentrations of these elements, with lower amounts in the older stems (2- to 5-year growth), the new acorns, and the leaves and stems of $E$. cistus. Consequently, the new growth of Holm oak, hereafter referred to as "oak leaves," was selected as the optimum biogeochemical sample medium for this study area.

At a given site, leaves from trees with trunk diameters ranging in size from 15 to $50 \mathrm{~cm}$ contained essentially the same trace-element content. However, at the same sites, trees with diameters less than $15 \mathrm{~cm}$ gave concentrations that were 20 to 40 percent lower. The higher concentration of trace elements found in trees with the larger trunk diameters may be due to their deeper root penetration. Also, samples of oak leaves that were collected in the months of July and August, during the active growing season, had 20 to 30 percent higher concentrations of arsenic and copper than did leaves from the same trees sampled in November and December. A visual comparison of the analytical results from the ash of Holm oak leaves to the ash of Cork oak leaves, which were collected from site 2 (fig. 3), indicated that both species had a similar biogeochemical response. Percent ash was measured for most samples and showed only minor variation for oak leaves, with values ranging from 2.8 to 3.1 percent.

Statistical summaries for the ICP-AES analysis of the ash from oak leaves collected in the Neves-Corvo area are listed in table 3. Concentration ranges for most of the elements listed in the tables fall within the analytical determination limits of the method used; however, some elements for several samples were reported as not detected at the lower limit of determination. For statistical computations, these qualified values were arbitrarily replaced with real values equal to 0.7 times the lower determination limit, as described by Miesch (1976). Univariate analysis of these data was used to obtain basic element-distribution information. Inspection of frequency-distribution histograms and the general 
Table 3. Statistical summary of chemical analyses for 73 samples of ash from oak leaves, NevesCorvo area, southern Portugal.

[Values preceded by " $<$ " indicate that the element was not detected at the lower limit of determination shown; these values were replaced with values equal to seven-tenths of the lower determination limit (Miesch, 1976) in determining geometric means and geometric deviations. See text for definition of "oak leaves"]

\begin{tabular}{lccccc}
\hline Variable & Minimum & Maximum & $\begin{array}{c}\text { Geometric } \\
\text { mean }\end{array}$ & $\begin{array}{c}\text { Geometric } \\
\text { deviation }\end{array}$ & $\begin{array}{c}\text { 75th } \\
\text { percentile }\end{array}$ \\
\hline $\mathrm{As}(\mathrm{ppm})$ & $<3.5$ & 81 & 9.4 & 1.8 & 14 \\
$\mathrm{Ba}(\mathrm{ppm})$ & 64 & 310 & 130 & 1.4 & 160 \\
$\mathrm{Ca}(\%)$ & 10 & 28 & 18 & 1.2 & 20 \\
$\mathrm{Co}(\mathrm{ppm})$ & 2.7 & 32 & 9.8 & 1.7 & 14 \\
$\mathrm{Cr}(\mathrm{ppm})$ & 4.5 & 46 & 11 & 1.4 & 13 \\
$\mathrm{Cu}(\mathrm{ppm})$ & 120 & 1,600 & 180 & 1.4 & 200 \\
$\mathrm{Fe}(\%)$ & 0.2 & 2.4 & 0.49 & 1.6 & 0.68 \\
$\mathrm{~K}(\%)$ & 5.9 & 12 & 8.9 & 1.2 & 10 \\
$\mathrm{Mg}(\%)$ & 3.2 & 9.8 & 5.7 & 1.3 & 6.4 \\
$\mathrm{Mn}(\%)$ & 0.6 & 6.2 & 2.4 & 1.6 & 3.5 \\
$\mathrm{Na}(\%)$ & 0.5 & 3.3 & 1.3 & 1.6 & 1.7 \\
$\mathrm{Ni}(\mathrm{ppm})$ & 19 & 240 & 62 & 2.0 & 100 \\
$\mathrm{P}(\%)$ & 1.2 & 3 & 2.0 & 1.2 & 2.3 \\
$\mathrm{~Pb}(\mathrm{ppm})$ & $<6$ & 65 & 14 & 1.9 & 21 \\
$\mathrm{Sr}(\mathrm{ppm})$ & 280 & 1,000 & 560 & 1.3 & 680 \\
$\mathrm{Ti}(\mathrm{ppm})$ & 21 & 97 & 48 & 1.4 & 60 \\
$\mathrm{Zn}(\mathrm{ppm})$ & 310 & 1,300 & 500 & 1.2 & 560 \\
\hline
\end{tabular}

agreement between the median and geometric mean for most of the elements indicated lognormal distribution of the data. Cumulative frequency plots helped determine the threshold value between anomalous and background populations for each element. Where bimodal or mixed populations were found by this method, the threshold value commonly occurred between the 70 th and 80 th percentiles. Consequently, the element-threshold values were selected to be those concentrations at the 75th percentile as given in table 3. Trace-element concentrations at and above these threshold values are considered to be anomalous.

Trace-element distribution maps for copper and arsenic in the ash of oak leaves are shown in figures 11 and 12 , and the relationship of the element pairs arsenic and copper, antimony and indium, and bismuth and tin in the ash of oak leaves to buried massive sulfide deposits along the traverse for samples 20-28 at Neves-Corvo are shown in figures 13-15.

Copper-Anomalous concentrations of copper were found in samples of the ash of oak leaves at sites clustered over buried massive sulfide bodies at Neves-Corvo in locations south and west of the town of A Do Corvo (fig. 11). The highest concentrations of copper in these areas occur over the Corvo orebody, the main copper deposit. Figure 13 shows the relationship of copper in oak leaves to the subsurface massive sulfide deposit at sample sites along the traverse for samples 20-28. The highest biogeochemical response for copper is shown between sample sites 24 and 26 over the Corvo orebody, in an area where near-surface faults are known to penetrate the ore zone. These faults and

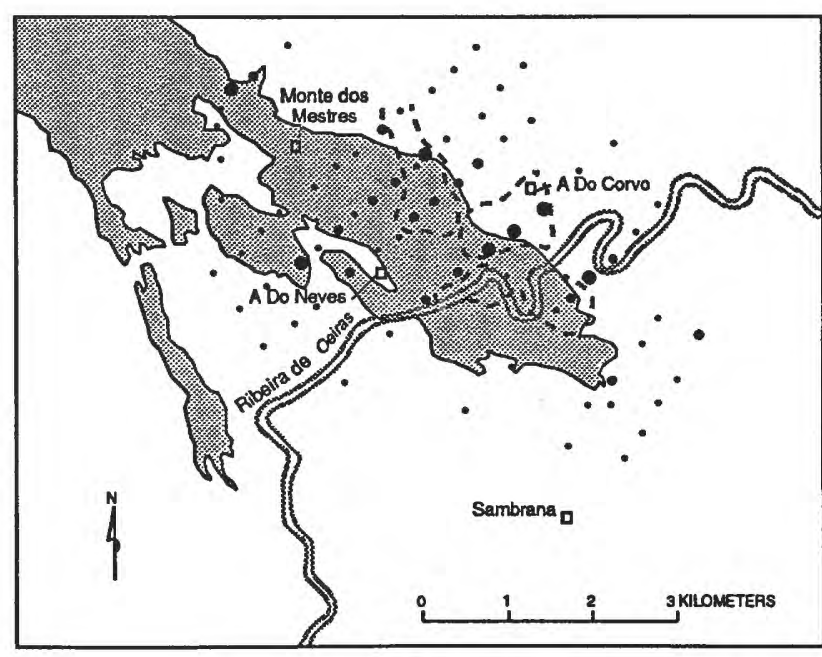

EXPLANATION

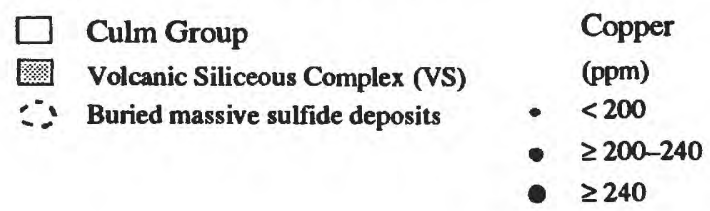

Figure 11. Distribution of copper in the ash of oak leaves, Neves-Corvo area, southern Portugal. Open squares indicate towns. See text for definition of oak leaves.

associated fractures may provide conduits for movement of ore-related metals from subsurface mineral deposits to the near-surface environment, where they are available for uptake by the oak trees. 


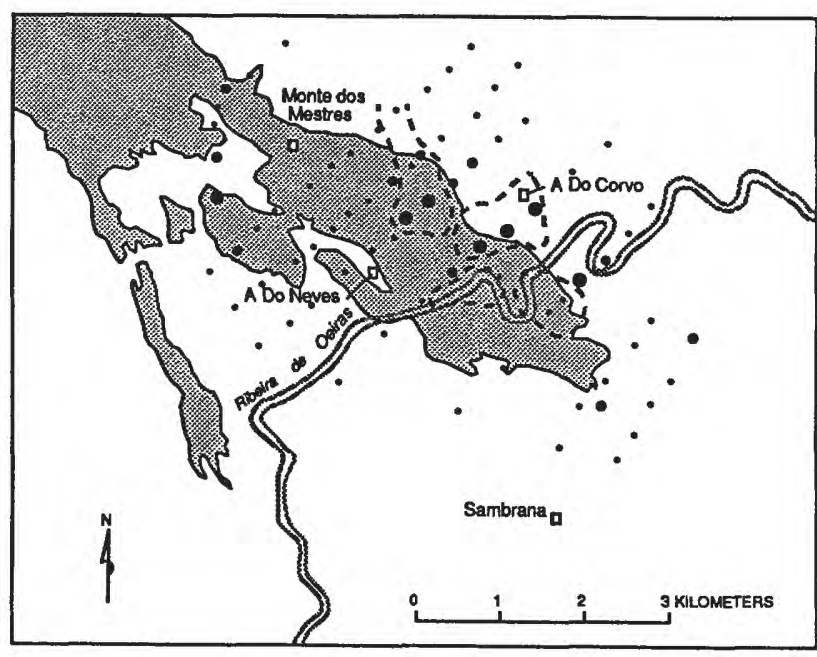

EXPLANATION

$\begin{array}{lll}\square & \text { Culm Group } & \text { Arsenic } \\ \square \text { Volcanic Siliceous Complex (VS) } & \text { (ppm) } \\ \because \quad \text { Buried massive sulfide deposits } & -<14 \\ & & \geq 14-20 \\ & -\geq 20\end{array}$

Figure 12. Distribution of arsenic in the ash of oak leaves, Neves-Corvo area, southern Portugal. Open squares indicate towns. See text for definition of oak leaves.

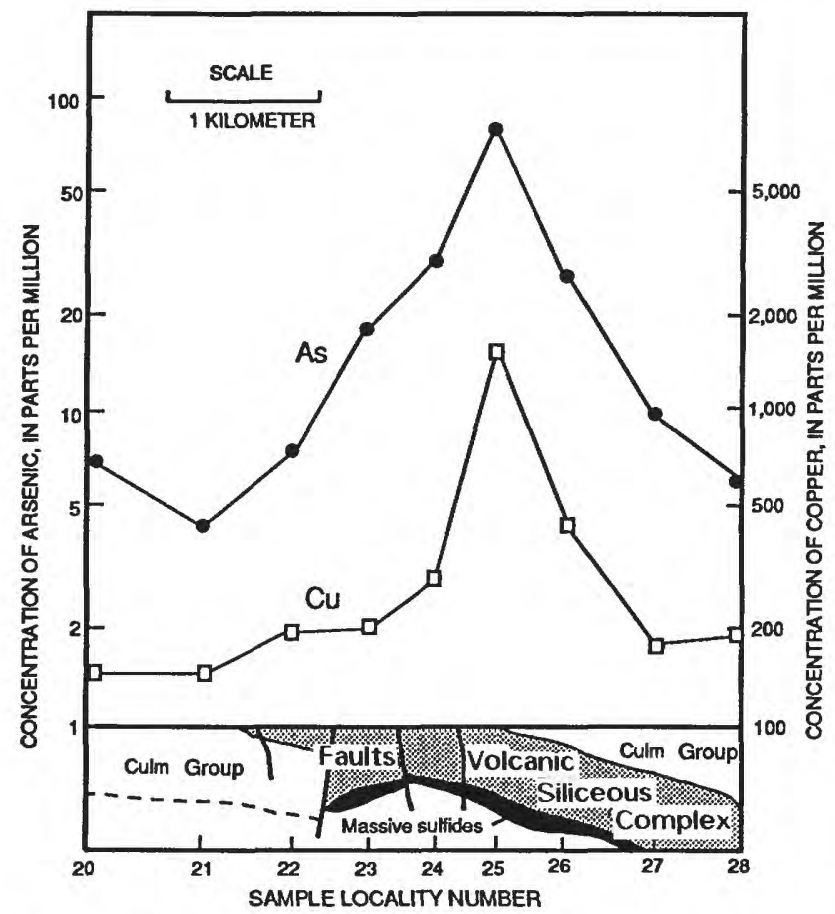

Figure 13. Transect along traverse containing sample localities 20-28 (see fig. 2), Neves-Corvo area, southern Portugal. Graph in upper part of figure shows relationship of arsenic and copper concentrations in the ash of oak leaves to buried massive sulfide deposits that are shown in the cross section in the bottom part of figure. See text for definition of oak leaves. Vertical scale on cross section is diagrammatic.

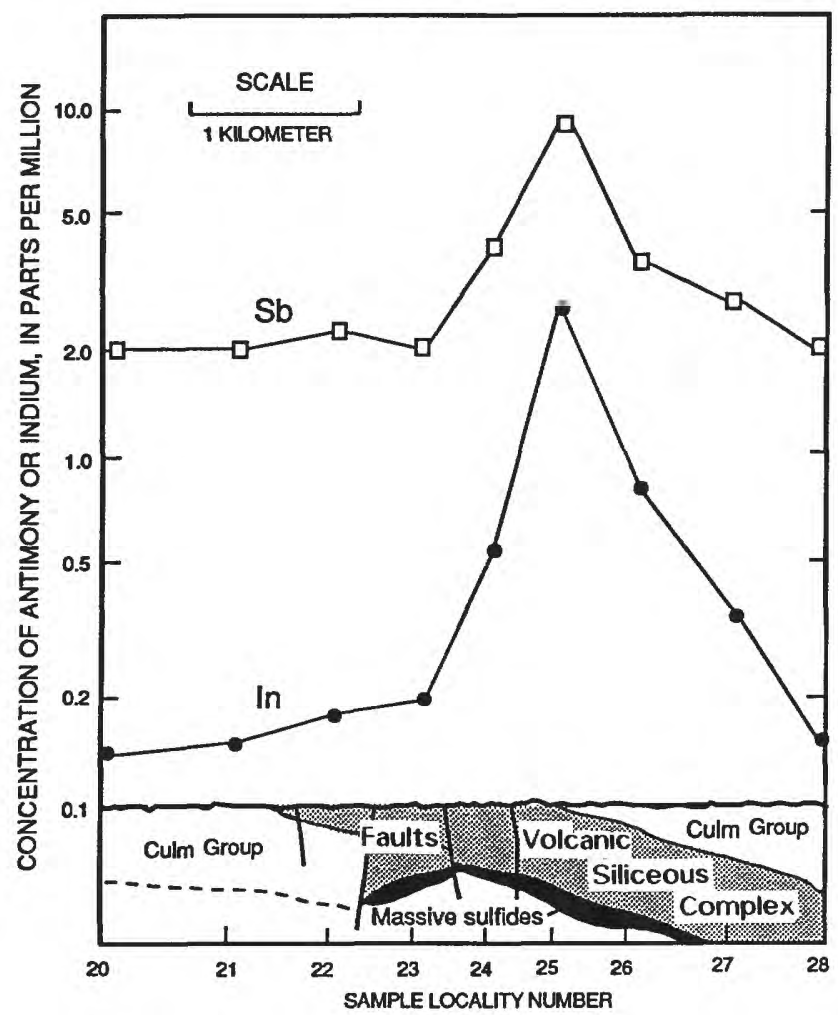

Figure 14. Transect along traverse containing sample localities 20-28 (see fig. 2), Neves-Corvo area, southern Portugal. Graph in upper part of figure shows relationship of antimony and indium concentrations in the ash of oak leaves to buried massive sulfide deposits that are shown in the cross section in the bottom part of figure. See text for definition of oak leaves. Vertical scale on cross section is diagrammatic.

Other locations containing anomalous concentrations of copper include samples over the known shallow sulfide deposit northwest of the town of Monte dos Mestres and northwest of A Do Neves where the anomalies may possibly be associated with local mineralized chert and sulfide-bearing manganese occurrences.

Arsenic.-Anomalous concentrations of arsenic were found in samples of oak leaves from sites clustered over buried massive sulfide bodies south and west of the town of A Do Corvo (fig. 12). The highest concentrations of arsenic in these areas occur over the Neves and Corvo orebodies. Figure 13 shows the relationship of arsenic in oak leaves to the subsurface massive sulfide deposit at samples sites along the traverse for samples 20-28. Arsenic exhibits a pattern similar to that of copper over the ore deposit; however, the biogeochemical response appears to be more widespread and intense for arsenic, with a greater anomaly-to-background ratio. This pattern may have resulted from a higher mobility for arsenic relative to copper from the ore zone to the nearsurface environment or from unique physiological mechanisms of arsenic uptake and translocation by the oak trees.

Antimony, bismuth, indium, and tin.-The distribution and relationship of these elements in the ash of oak leaves to 


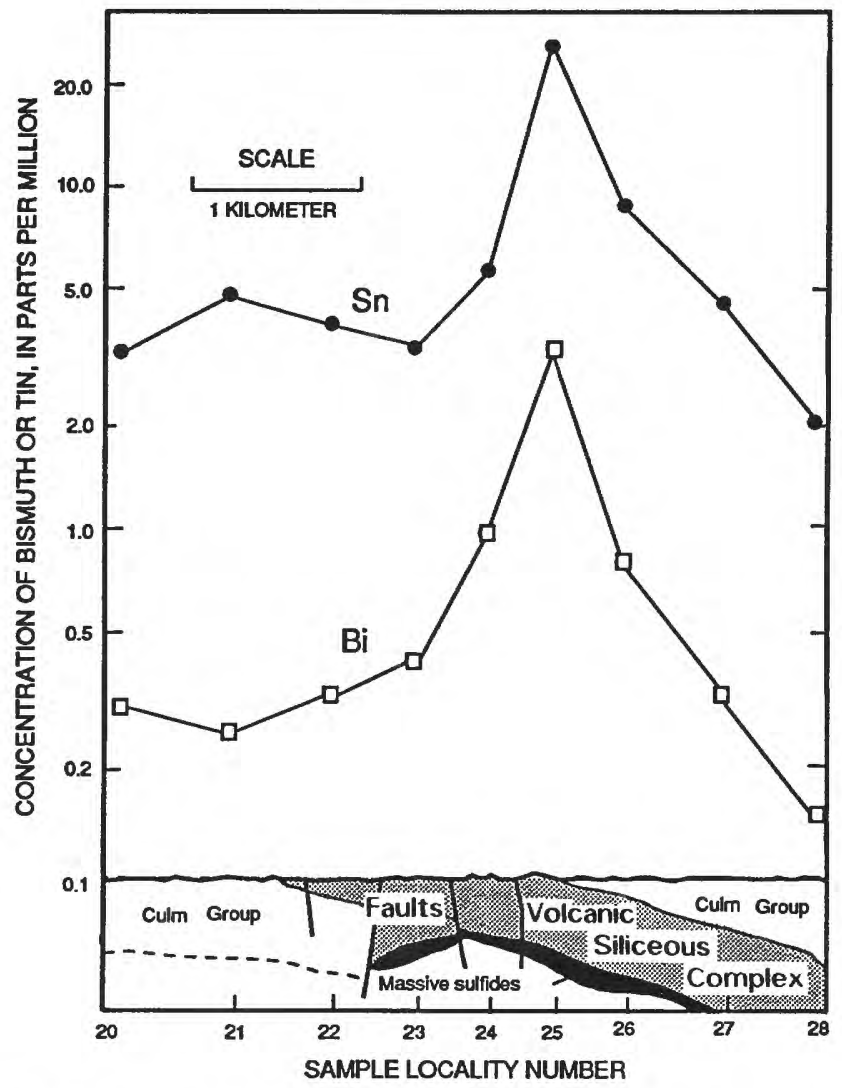

Figure 15. Transect along traverse containing sample localities 20-28 (see fig. 2), Neves-Corvo area, southern Portugal. Graph in upper part of figure shows relationship of bismuth and tin concentrations in the ash of oak leaves to buried massive sulfide deposits that are shown in the cross section in the bottom part of figure. See text for definition of oak leaves. Vertical scale on cross section is diagrammatic.

the buried massive sulfide deposits are shown in figures 14 and 15. Each of these ore-related elements shows a biogeochemical response above the buried ore zones along this traverse, with the highest concentrations located between sample sites 24 and 26 above the Corvo massive sulfide body. Bismuth and indium display the greatest response, with relatively higher anomaly-to-background ratios as compared to antimony and tin.

Other elements.-Anomalous clusters for lead and zinc (not shown here) were not found in the ash of oak leaves; however, high lead and zinc concentrations were obtained at scattered locations such as at sample sites 14 (lead $=36$ ppm), $25($ lead $=65 \mathrm{ppm}), 48($ lead $=37 \mathrm{ppm}), 54($ zinc $=720$ ppm), 59 (zinc $=720 \mathrm{ppm})$, and over a known near-surface sulfide deposit at site 71 ( $\mathrm{zinc}=1,300 \mathrm{ppm}$ ).

\section{SUMMARY OF BIOGEOCHEMICAL STUDY}

Analytical results by ICP-AES and ICP-MS techniques on samples of vegetation collected in the Neves-Corvo study area delineate several anomalous areas, some of which are associated with known, buried massive sulfide deposits. The highest concentrations of ore-related elements, such as antimony, arsenic, bismuth, copper, indium, and tin, were found in the first-year growth of leaves and stems of Holm oak (Quercus ilex). Optimum biogeochemical response for oreassociated elements occurred in samples collected during the active growing season (July-August) and from trees that had trunk diameters greater than $15 \mathrm{~cm}$. The overall best biogeochemical indicator of sulfides in the Neves-Corvo study area seems to be arsenic in the ash of Holm oak leaves, possibly resulting from the high mobility of this element in the subsurface environment and unique translocation mechanisms in Holm oak trees. Additional elements that occur in anomalous concentrations in the oak leaves above the buried deposit include antimony, bismuth, copper, indium, and tin. Other trace elements that were determined, such as lead and zinc, did not show an obvious spatial relationship with the ore deposit.

The results of the biogeochemical study in the NevesCorvo area indicate that biogeochemical exploration methods, specifically the sampling and analysis of the first-year growth of oak trees during the active growing season, may be useful to exploration programs in the Portuguese Pyrite Belt in the search for concealed massive sulfide deposits.

\section{HYDROGEOCHEMICAL STUDY}

Circulating ground water in contact with buried ore deposits may dissolve and transport trace elements that are associated with the deposits and form aqueous dispersion patterns. The detection of these dispersion patterns, by collecting and analyzing ground water, forms the basis of hydrogeochemical exploration. Applications of hydrogeochemical exploration methods in various climates and geochemical environments have been discussed by Boyle and others (1971) and Miller (1979). The hydrogeochemical study in the Neves-Corvo area was undertaken to determine if the chemistry of ground water, collected from wells, would reveal the presence of the concealed massive sulfide deposit. If positive results were obtained from this study, then hydrogeochemical techniques could be used advantageously in exploration programs in the PPB, and possibly in other areas of Portugal because of the large number and general distribution of water wells available to sample.

\section{SAMPLE COLLECTION, PREPARATION, AND ANALYSIS}

In July of 1987 and 1988, samples of ground water were collected from open water wells and from pumped wells in the Neves-Corvo area (fig. 16). The water samples were collected from the wells by lowering a polyethylene bottle into the well with a nylon cord and filling the bottle with water. 
Table 4. Analytical methods used of analysis of water samples, Portuguese Pyrite Belt, Portugal.

\begin{tabular}{lll}
\hline \multicolumn{1}{c}{ Variable } & \multicolumn{1}{c}{ Method } & \multicolumn{1}{c}{ Reference } \\
\hline Alkalinity & Gran's plot potentiometric titration & Orion Research Inc. (1978) \\
$\mathrm{Cl}, \mathrm{F}, \mathrm{SO}_{4}$ & Ion chromatography & Fishman and Pyen (1979) \\
$\mathrm{Ca}, \mathrm{K}, \mathrm{Mg}, \mathrm{Na}, \mathrm{SiO}_{2}$ & Flame atomic absorption spectrophotometry & Perkin-Elmer Corp. (1976) \\
$\mathrm{Fe}, \mathrm{Mn}$ & Flameless atomic absorption spectrophotometry & Perkin-Elmer Corp. (1977) \\
$\mathrm{As}, \mathrm{Co}, \mathrm{Cr}, \mathrm{Cu}, \mathrm{Mo}, \mathrm{Ni}, \mathrm{Pb}, \mathrm{Sb}, \mathrm{Zn}$ & Inductively coupled plasma-mass spectrometry & Lichte and others (1987) \\
$\mathrm{Au}$ & Anion exchange-flameless atomic absorption & McHugh (1986) \\
\hline
\end{tabular}

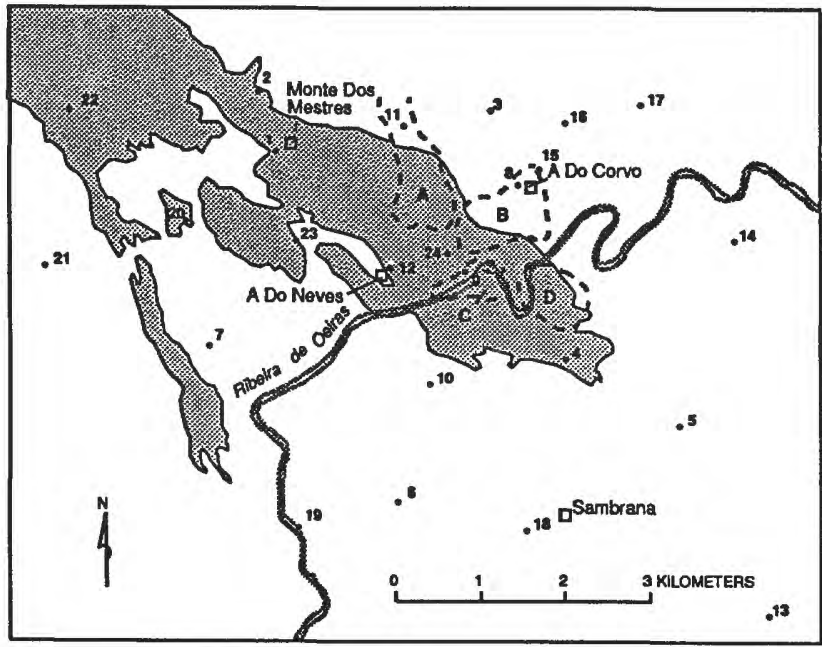

EXPLANATION

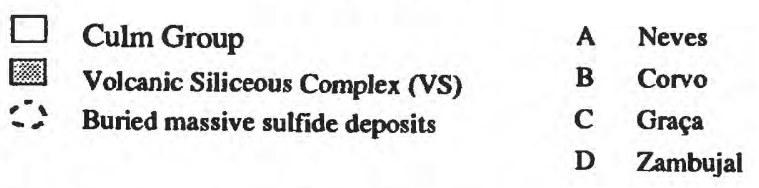

Figure 16. Water sample localities, Neves-Corvo area, southern Portugal. Numbers indicate sites at which water samples were collected; letters A-D indicate ore deposits; open squares indicate towns.

Where pumps were encountered (sample sites 8 and 12), the water was allowed to flow from the pump for at least $5 \mathrm{~min}$ utes before a sample was collected. At each sample site, a $50-\mathrm{mL}$ aliquot of water was filtered through a $0.45-\mu \mathrm{m}$ membrane filter and acidified to a $\mathrm{pH}$ of approximately 2 with five drops of reagent-grade, concentrated nitric acid. A $250-\mathrm{mL}$ aliquot of water was collected at each site and left untreated. At two sample sites (8 and 24), 1-L aliquots of untreated water were also collected. All the water samples were stored in acid-rinsed polyethylene bottles.

Water temperature, $\mathrm{pH}$, and specific conductivity were measured at each site. Antimony, As, $\mathrm{Co}, \mathrm{Cu}, \mathrm{Cr}, \mathrm{Fe}, \mathrm{Mn}$, $\mathrm{Mo}, \mathrm{Ni}, \mathrm{Pb}, \mathrm{SiO}_{2}$, and $\mathrm{Zn}$ were determined using the filtered and acidified samples. Alkalinity, chloride, sulfate, fluoride, calcium, magnesium, potassium, and sodium were determined on the untreated samples. Gold was determined on the two 1-L samples after filtration and acidification in the laboratory. The analytical techniques used for each constituent measured in the water samples are listed in table 4.

\section{RESULTS OF HYDROGEOCHEMICAL STUDY}

Analytical results for water samples collected during orientation studies in July 1987 in the Neves-Corvo area showed that anomalous concentrations of several ore-associated elements were present in the ground-water system above the buried massive sulfide deposit. Additional sampling of ground water in the Neves-Corvo area and in other geochemical study areas in southern Portugal (discussed later in this report), was carried out in July 1988. Statistical summaries of the chemical analyses for water samples are listed in table 5. Concentration ranges for most of the variables listed in the tables fall within the analytical determination limits of the respective methods used; however, some variables for several samples were reported as not detected at the lower limit of determination. For the statistical computations, these qualified values were arbitrarily replaced with real values equal to 0.7 times the lower determination limit, as described by Miesch (1976). Univariate analysis of these data was used to obtain basic distribution information on the variables measured. Inspection of frequency-distribution histograms and the general agreement between the median and geometric mean for most of the variables indicated lognormal distribution of the data. Cumulative frequency plots helped determine the threshold value between anomalous and background populations for each variable. Where bimodal or mixed populations were found by this method, the threshold value commonly occurred between the 70th and 80 th percentiles. Consequently, the threshold values were selected to be those concentrations at the 75th percentile, as given in table 5. Concentrations at and above these threshold values are considered to be anomalous. Trace-element distribution maps for copper, arsenic, antimony, molybdenum, and sulfate in ground-water samples collected in the NevesCorvo area are shown in figures 17-21.

Copper.-Anomalous concentrations of copper were found in samples of water from sites in the vicinity of the buried ore deposit at locations between the towns of A Do Neves and A Do Corvo (fig. 17). The highest concentrations of copper in this area are from samples collected from a 
Table 5. Statistical summary of chemical analyses for $\mathbf{5 5}$ water samples, Neves-Corvo and other geochemical study areas, southern Portugal.

[Values preceded by "<"indicate that the element was not detected at the lower limit of determination shown; these values were replaced with values equal to seven-tenths of the lower determination limit (Miesch, 1976) in determining geometric means and geometric deviations. Arithmetic mean and standard deviation are shown below for $\mathrm{pH}$ ]

\begin{tabular}{lccccc}
\hline Variable & Minimum & Maximum & $\begin{array}{c}\text { Geometric } \\
\text { mean }\end{array}$ & $\begin{array}{c}\text { Geometric } \\
\text { deviation }\end{array}$ & $\begin{array}{c}75 \text { th } \\
\text { percentile }\end{array}$ \\
\hline Alkalinity $(\mathrm{mg} / \mathrm{L})$ & 5.0 & 620 & 160 & 3.1 & 343 \\
$\mathrm{As}(\mu \mathrm{g} / \mathrm{L})$ & 1.0 & 90 & 2.0 & 3.0 & 3 \\
$\mathrm{Ca}(\mathrm{mg} / \mathrm{L})$ & 5.0 & 120 & 32 & 2.2 & 59 \\
$\mathrm{Cl}(\mathrm{mg} / \mathrm{L})$ & 6.0 & 560 & 76 & 2.4 & 150 \\
$\mathrm{Co}(\mu \mathrm{g} / \mathrm{L})$ & $<0.1$ & 8.6 & 0.21 & 2.7 & 0.31 \\
$\mathrm{Cond}(\mu \mathrm{s})$ & 110 & 2,300 & 660 & 1.8 & 980 \\
$\mathrm{Cr}(\mu \mathrm{g} / \mathrm{L})$ & $<0.1$ & 14 & 0.56 & 3.2 & 0.66 \\
$\mathrm{Cu}(\mu \mathrm{g} / \mathrm{L})$ & 1.0 & 160 & 3.3 & 2.0 & 5 \\
$\mathrm{~F}(\mathrm{mg} / \mathrm{L})$ & $<0.1$ & 2.0 & 0.30 & 2.5 & 0.54 \\
$\mathrm{Fe}(\mu \mathrm{g} / \mathrm{L})$ & $<10$ & 690 & 27 & 2.3 & 40 \\
$\mathrm{~K}(\mathrm{mg} / \mathrm{L})$ & 0.1 & 23 & 0.76 & 3.2 & 1.3 \\
$\mathrm{Mg}(\mathrm{mg} / \mathrm{L})$ & 3.0 & 75 & 18 & 2.2 & 32.8 \\
$\mathrm{Mn}(\mu \mathrm{g} / \mathrm{L})$ & $<10$ & 13,000 & 26 & 5.3 & 32.5 \\
$\mathrm{Mo}(\mu \mathrm{g} / \mathrm{L})$ & $<0.1$ & 16 & 0.47 & 4.0 & 1 \\
$\mathrm{Na}(\mathrm{mg} / \mathrm{L})$ & 13 & 420 & 67 & 1.9 & 91.5 \\
$\mathrm{Ni}(\mu \mathrm{g} / \mathrm{L})$ & $<0.1$ & 18 & 1.5 & 2.9 & 3 \\
$\mathrm{~Pb}(\mu \mathrm{g} / \mathrm{L})$ & $<0.1$ & 29 & 0.50 & 4.0 & 1.45 \\
$\mathrm{pH}$ & 4.7 & 9.1 & 7.3 & 1.1 & 7.8 \\
$\mathrm{SO}(\mathrm{mg} / \mathrm{L})$ & 4.0 & 270 & 34 & 2.3 & 48.0 \\
$\mathrm{Sb}(\mu \mathrm{g} / \mathrm{L})$ & $<0.1$ & 120 & 0.22 & 5.0 & 0.30 \\
$\mathrm{SiO}(\mathrm{mg} / \mathrm{L})$ & $<1.5$ & 47 & 15 & 2.0 & 22 \\
$\mathrm{Temp}\left({ }^{\circ} \mathrm{C}\right)$ & 16.7 & 28.9 & 20.6 & 0.6 & 21.7 \\
$\mathrm{Zn}(\mu \mathrm{g} / \mathrm{L})$ & $<0.1$ & 400 & 4.8 & 3.2 & 8.2 \\
\hline
\end{tabular}

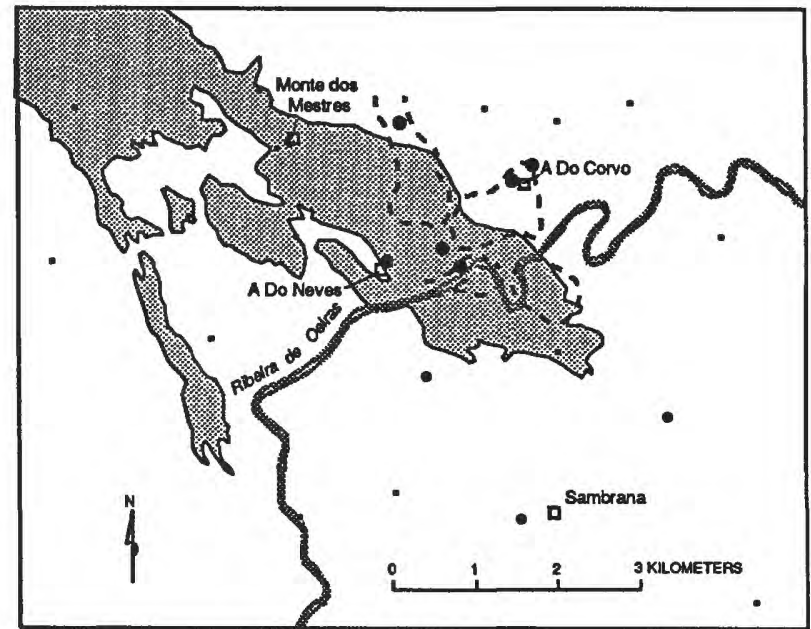

EXPLANATION

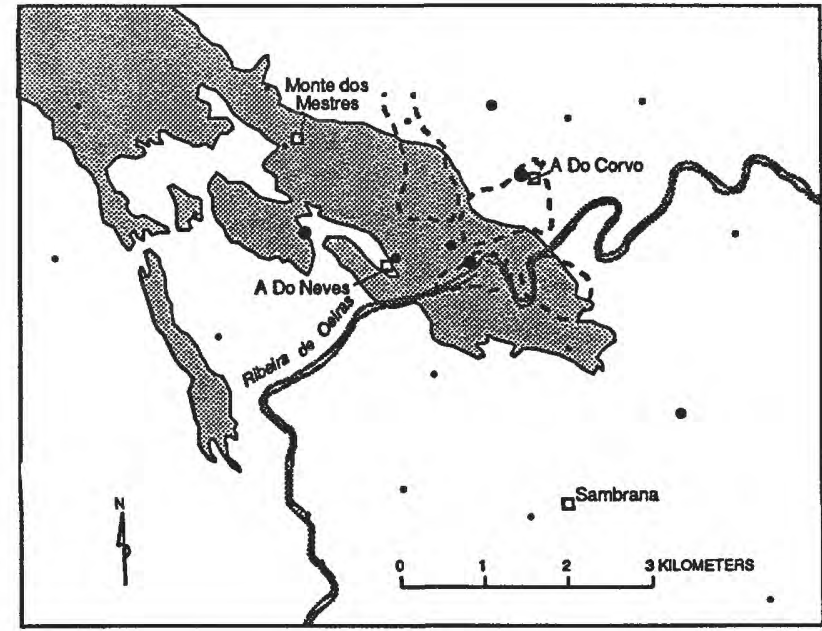

EXPLANATION

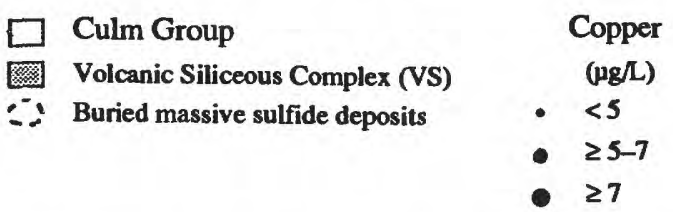

Figure 17. Distribution of copper in water, Neves-Corvo area, southern Portugal. Open squares indicate towns.

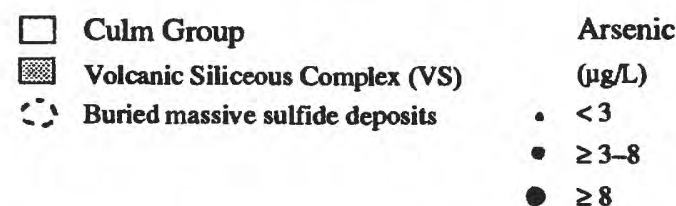

Figure 18. Distribution of arsenic in water, Neves-Corvo area, southern Portugal. Open squares indicate towns. 


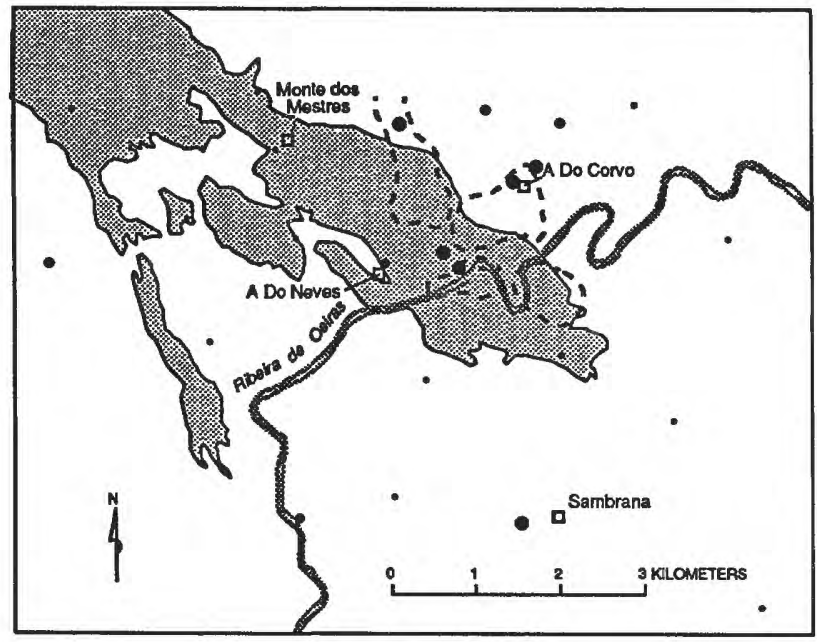

EXPLANATION

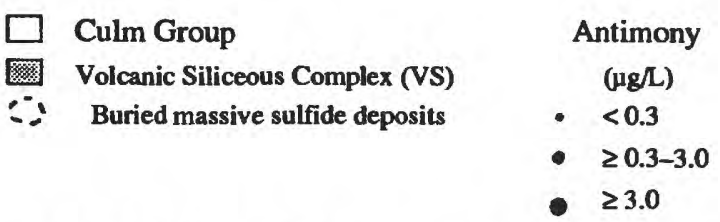

Figure 19. Distribution of antimony in water, Neves-Corvo area, southern Portugal. Open squares indicate towns.

pump, near A Do Corvo, at site $8(9 \mu \mathrm{g} / \mathrm{L})$, and from a well located adjacent to the Ribeira de Oeiras, at site $9(8 \mu \mathrm{g} / \mathrm{L})$. By contrast, the geometric mean for copper in water is 3.3 $\mu \mathrm{g} / \mathrm{L}$ (table 5). Background values for copper from wells located away from known massive sulfide deposits in areas dominated by rocks of the Culm Group, at sites 6, 7, 13, and 14 (fig. 16), ranged from 3 to $4 \mu \mathrm{g} / \mathrm{L}$. Similarly, water collected from wells in areas dominated by rocks of the Volcanic Siliceous Complex, at sites $1,4,20$, and 22, contained copper concentrations ranging from 2 to $4 \mu \mathrm{g} / \mathrm{L}$. A sample of mine water, originating from beneath the ore horizon at a depth of $600 \mathrm{~m}$ below ground level and pumped to the surface through steel pipes, was collected at site 24 . The mine water was alkaline ( $\mathrm{pH}>7.0$ ), with a measured $\mathrm{pH}$ of 9.1, and contained only a moderately anomalous concentration of copper $(6 \mu \mathrm{g} / \mathrm{L})$. This relatively low concentration of copper probably results from the limited mobility of many metallic cations, including $\mathrm{Cu}^{++}$, in alkaline waters. The $\mathrm{pH}$ of hydrolysis, which is the $\mathrm{pH}$ at which elements in solution begin to precipitate as hydroxides, is only 5.3 for $\mathrm{Cu}^{++}$(Britton, 1955). The highest concentration of copper in ground water at Neves-Corvo was from a well at site 23 , northwest of the town of A Do Neves. That water contained $160 \mu \mathrm{g} / \mathrm{L}$ copper and was acidic ( $\mathrm{pH}<7.0)$, with a measured $\mathrm{pH}$ of 6.7 . The lower $\mathrm{pH}$ of the water in this well is more favorable for copper solubility and mobility. The chemistry of the water of this sample is likely affected by the exposed and near-surface mineralized chert and sulfide-bearing manganese occurrences that are locally present; however, the high

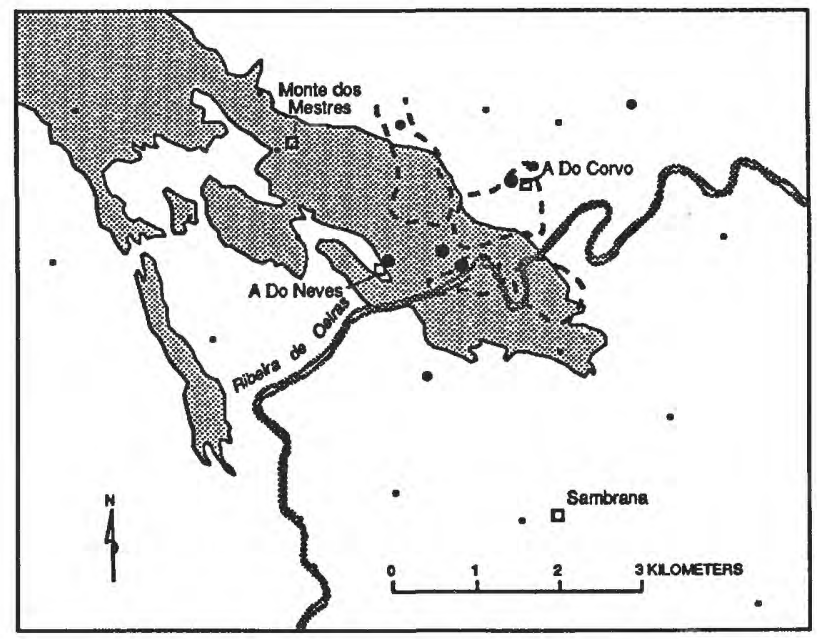

EXPLANATION

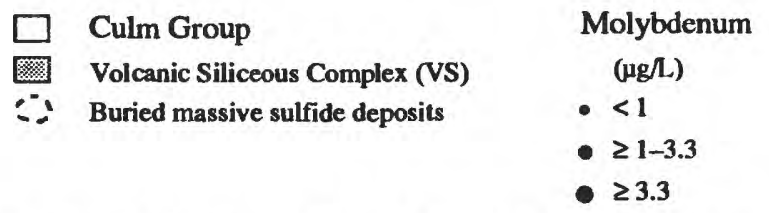

Figure 20. Distribution of molybdenum in water, Neves-Corvo area, southern Portugal. Open squares indicate towns.

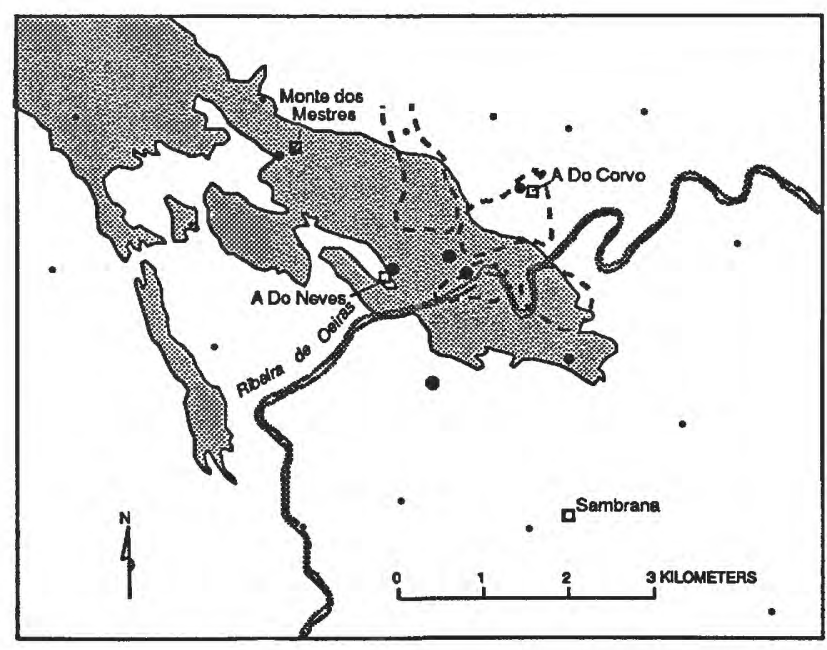

EXPLANATION

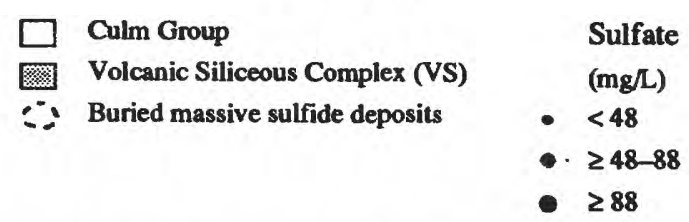

Figure 21. Distribution of sulfate in water, Neves-Corvo area, southern Portugal. Open squares indicate towns.

copper concentration and low $\mathrm{pH}$ of the water here could have resulted from contact with unknown buried sulfide minerals. 
Arsenic.-Anomalous concentrations of arsenic were found in water samples from sites over and peripheral to the buried sulfide deposit (fig. 18). Highest concentrations of arsenic in this area are from samples collected from a pump in the town of A Do Corvo, at site $8(12 \mu \mathrm{g} / \mathrm{L})$; from a well near the Ribeira de Oeiras, at site $9(36 \mu \mathrm{g} / \mathrm{L})$; from a well east of Monte dos Mestres, at site $11(8 \mu \mathrm{g} / \mathrm{L})$; from a well northeast of A Do Corvo, at site $15(15 \mu \mathrm{g} / \mathrm{L})$; and from the sample of mine water originating from below the ore horizon at site $24(90 \mu \mathrm{g} / \mathrm{L})$. By contrast, the geometric mean for arsenic in water is $2.0 \mu \mathrm{g} / \mathrm{L}$ (table 5). Background values for arsenic from wells located away from known sulfide deposits in areas dominated by rocks of the Culm Group, at sites 6, 7,13 , and 14 (fig. 16), ranged from $<1.0$ to $2.0 \mu \mathrm{g} / \mathrm{L}$. Similarly, water collected from wells in areas dominated by Volcanic Siliceous Complex rocks, at sites 1, 4, 20, and 22, contained arsenic concentrations ranging from $<1.0$ to 2.0 $\mu \mathrm{g} / \mathrm{L}$. The $\mathrm{pH}$ of the water from the anomalous sample sites ranged from 7.2 to 9.1. This alkaline water favors the solubility and mobility of arsenic as complex anionic species and may be a controlling factor in the anomalous dispersion pattern of this element. The alkalinity may also have caused a higher anomaly-to-background ratio for arsenic than for copper above the buried massive sulfide deposit. A water sample collected from a well west of the town of Sambrana also contained high concentrations of arsenic $(28 \mu \mathrm{g} / \mathrm{L})$. The cause of this anomaly is unknown; however, based on the topographic relief in this area, the ground-water source at this well is likely from the south or southwest, suggesting that the area to the south could contain buried sulfide mineral deposits.

Antimony and Molybdenum.-Anomalous concentrations of antimony and molybdenum were also found in water samples from the area around the buried sulfide deposit at Neves-Corvo (figs. 19 and 20). The highest concentrations of antimony and molybdenum are in samples of water collected from pumps, near A Do Corvo and A Do Neves, at sites $8(6 \mu \mathrm{g} / \mathrm{L} \mathrm{Sb}$ and $8 \mu \mathrm{g} / \mathrm{L} \mathrm{Mo})$ and $12(18$ and $5 \mu \mathrm{g} / \mathrm{L})$; from a well, near the Ribeira de Oeiras, at site 9 (11 and 7 $\mu \mathrm{g} / \mathrm{L})$; from a well, east of Monte dos Mestres, at site 11 ( 0.4 and $3.3 \mu \mathrm{g} / \mathrm{L}$ ); from well water, northeast of A Do Corvo, at site $15(0.4$ and $7 \mu \mathrm{g} / \mathrm{L})$; and from the sample of mine water at site $24(120$ and $16 \mu \mathrm{g} / \mathrm{L})$. By contrast, the geometric means for antimony and molybdenum in water are $0.22 \mu \mathrm{g} / \mathrm{L}$ and $0.47 \mu \mathrm{g} / \mathrm{L}$ respectively (table 5). Background values for antimony and molybdenum from wells located away from known sulfide deposits in areas dominated by rocks of the Culm Group, at sites 6, 7, 13, and 14 (fig. 16), ranged from 0.1 to $0.2 \mu \mathrm{g} / \mathrm{L}$ for antimony and from 0.2 to $0.7 \mu \mathrm{g} / \mathrm{L}$ for molybdenum. Similarly, water samples collected from wells in areas dominated by rocks of the Volcanic Siliceous Complex, at sites $1,4,20$, and 22 , contained concentrations of antimony ranging from $<0.1$ to $0.2 \mu \mathrm{g} / \mathrm{L}$ and concentrations of molybdenum ranging from 0.3 to $0.8 \mu \mathrm{g} / \mathrm{L}$. The distribution of anomalous antimony and molybdenum in the water samples is similar to that of arsenic and probably resulted from the occurrence of these elements as complex anionic species, which are also relatively mobile in the alkaline ground-water environment.

Sulfate.-Anomalous concentrations of sulfate were found in water samples in the vicinity of the buried ore deposit at locations between the towns of A Do Neves and A Do Corvo (fig. 21). The highest concentrations of sulfate in this area occurred in samples from pumps, near A Do Corvo and A Do Neves, at sites $8(87 \mathrm{mg} / \mathrm{L})$ and $12(220 \mathrm{mg} / \mathrm{L})$; from a well, near the Ribeira de Oeiras, at site $9(130 \mathrm{mg} / \mathrm{L})$; from well water collected south of A Do Neves, at site 10 ( 97 $\mathrm{mg} / \mathrm{L})$; and from the mine water at site $24(270 \mathrm{mg} / \mathrm{L})$. By contrast, the geometric mean for sulfate is $34 \mathrm{mg} / \mathrm{L}$ (table 5). Background values for sulfate in water from wells located away from known sulfide deposits in areas dominated by rocks of the Culm Group, at sites 6, 7, and 14 (fig. 16), ranged from 31 to $37 \mathrm{mg} / \mathrm{L}$. Similarly, water samples collected from wells in areas dominated by rocks of the Volcanic Siliceous Complex, at sites 20, and 22, contained sulfate concentrations ranging from 30 to $38 \mathrm{mg} / \mathrm{L}$. The anomalous sulfate concentrations are probably derived from the dissolution of sulfide minerals associated with the buried ore deposit.

Other elements.-Other variables that were measured in the water samples in the Neves-Corvo area did not show a spatial relationship with the buried ore deposit; however, several samples from individual sites did contain high concentrations of some variables. A water sample collected from a well northwest of A Do Neves, at site 23, near the mineralized chert and sulfide-bearing manganese occurrences, contained $29 \mu \mathrm{g} / \mathrm{L}$ lead and $400 \mu \mathrm{g} / \mathrm{L}$ zinc. The $\mathrm{pH}$ for this sample (6.7) favors the solubility and mobility of lead and zinc as cationic species. The sample of mine water from site 24 , with the $\mathrm{pH}$ of 9.1 , contained only $0.3 \mu \mathrm{g} / \mathrm{L}$ lead and $2 \mu \mathrm{g} / \mathrm{L}$ zinc, which demonstrates the limited mobility of these elements in alkaline waters.

Anomalous concentrations of gold were reported in the two 1-L samples collected from a pump, near A Do Corvo, at site $8(2 \mathrm{ng} / \mathrm{L})$, and from the sample of mine water at site $24(4 \mathrm{ng} / \mathrm{L})$. These gold values probably reflect gold associated with the buried massive sulfide deposit at Neves-Corvo, and they suggest limited solubility and mobility of gold in high-pH waters around these types of deposits.

\section{DISCUSSION OF HYDROGEOCHEMICAL RESULTS}

Mine development activities prior to our hydrogeochemical study in the Neves-Corvo area included mine dewatering processes to reduce the inflow of water into active underground workings. Mine water is pumped to the surface through steel pipes from $600 \mathrm{~m}$ below the ground level and is discharged into the Ribeira de Oeiras at a point approximately $200 \mathrm{~m}$ east of water sample site 9 (fig. 16). Analysis of a sample of this mine water, collected at site 24, indicated anomalous amounts of chromium $(8 \mu \mathrm{g} / \mathrm{L})$, a water 
temperature of $28.8^{\circ} \mathrm{C}$, and a high $\mathrm{pH}$ of 9.1 . The high temperature and $\mathrm{pH}$ are normal for mine water from this depth (Fernandez-Rubio and others, 1988), and the high chromium may have resulted from the dissolution of this metal from contact of water with the $600 \mathrm{~m}$ of steel pipe. A water sample collected in a nearby well, adjacent to the Ribeira de Oeiras at site 9, contained slightly elevated levels of chromium $(1.3 \mu \mathrm{g} / \mathrm{L})$, a temperature measured at $26.7^{\circ} \mathrm{C}$, and a relatively high $\mathrm{pH}$ of 7.8. The chemistry of this sample is similar in some respects to the chemistry of the sample from site 24 , which suggests that it may be partly influenced by mine water pumped to the surface during mine dewatering. Other nearby water samples collected from sites 8 and 12 , at locations at least $1 \mathrm{~km}$ away from the point of discharge of the pumped mine water, have temperatures of $19.4^{\circ} \mathrm{C}$ and $20.0^{\circ} \mathrm{C}$ and $\mathrm{pH}$ readings of 7.2 and 7.0. The chromium concentrations in the water samples from these two sites are 0.5 and $0.3 \mu \mathrm{g} / \mathrm{L}$, respectively. These findings are considered normal, and it is deemed unlikely that the water at sites 8 and 12 has been contaminated to any degree by the pumped mine water.

In a hydrologic study at the Neves-Corvo deposit, Fernandez-Rubio and others (1988) defined three hydrologic units: (1) a surface-system aquifer including the alluvial terrace and the zone of weathering, (2) an intermediate-system aquifer with primary permeability provided by vertical faults, and (3) a deep-system aquifer with permeability supported by microfissures in the ore deposits. In more recent studies of the local hydrology, Nunes and others (1990) describe the surface system as including the zone of decompression of the rock mass to a depth of approximately $30 \mathrm{~m}$, with the water table following local topography and flowing toward the Ribeira de Oeiras, with the exception of the zone of influence of the mine. Hanes and others (1990) stated that the intermediate hydrologic system acts purely as a water transfer system between the deep system, in contact with the ore deposit, and the surface system. They further noted that the deep system, with intense fracturing around the orebodies, would have a high fracture permeability. This would, in effect, provide a large surface area of contact between the ground water in the deep system and the ore and accessory minerals in the buried massive sulfide deposit. The large surface area of contact would favor dissolution of ore-related elements from the deposit into the deep ground-water system. Nunes and others (1990) concluded that, prior to mine development, vertical ascent of water would take place along decompression zones, such as faults and fractures. This ascent of water from the deep system to the surface system would provide a possible mechanism of vertical hydromorphic dispersion of ore-related elements to the near-surface ground-water environment.

The sample of mine water, collected from site 24 (fig. 16) and originating from the deep hydrologic system in contact with the massive sulfide orebodies, contained highly anomalous concentrations of arsenic $(90 \mu \mathrm{g} / \mathrm{L})$, molybdenum (16 $\mu \mathrm{g} / \mathrm{L})$, and antimony $(120 \mu \mathrm{g} / \mathrm{L})$. This demonstrates that ore-related elements are being dissolved and dispersed into the lower ground-water system at NevesCorvo. Samples of water, collected from pumps at sites 8 and 12 (fig. 16), contain moderately anomalous concentrations of arsenic ( 12 and $5 \mu \mathrm{g} / \mathrm{L}$ ), antimony ( 6 and $18 \mu \mathrm{g} / \mathrm{L}$ ), and molybdenum ( 8 and $5 \mu \mathrm{g} / \mathrm{L}$ ). The source of the water from these pumped wells is at a depth of 30 to $60 \mathrm{~m}$ below ground level, which corresponds to the intermediate hydrologic system of Fernandez-Rubio and others (1988) and the water transfer system of Nunes and others (1990). The analytical results of these pumped samples demonstrates that anomalous concentrations of ore-related elements are being hydromorphically dispersed from the deep hydrologic system, in contact with the orebodies, into the intermediate hydrologic system at Neves-Corvo. Samples of water collected from wells at sites 11 and 15 (fig. 16) at depths of $1.5 \mathrm{~m}$ and $3.5 \mathrm{~m}$ below ground level, contained anomalous concentrations of arsenic ( 8 and $15 \mu \mathrm{g} / \mathrm{L}$ ), antimony $(0.4$ and $0.4 \mu \mathrm{g} / \mathrm{L}$ ), and molybdenum ( 3.3 and $7 \mu \mathrm{g} / \mathrm{L}$ ). By contrast, background concentrations for arsenic, antimony, and molybdenum in water samples from wells located away from the ore deposit in areas dominated by rocks of the Volcanic Siliceous Complex, at sites $6,7,13$, and 14 (fig. 16), ranged from $<1.0$ to $2.0 \mu \mathrm{g} / \mathrm{L}$ for arsenic, from $<0.1$ to $0.2 \mu \mathrm{g} / \mathrm{L}$ for antimony, and from 0.3 to $0.8 \mu \mathrm{g} / \mathrm{L}$ for molybdenum. The analysis of these water samples from wells in the surface hydrologic system demonstrates the hydromorphic dispersion of anomalous concentrations of ore-related elements from the deep hydrologic system to the surface ground-water environment.

\section{SUMMARY OF HYDROGEOCHEMICAL STUDY}

Analytical results by ICP-MS and other sensitive analytical techniques on samples of water collected from open wells and pumping wells in the Neves-Corvo area show anomalous hydrogeochemical dispersion patterns associated with the subsurface massive sulfide bodies. Strongly anomalous concentrations of antimony, arsenic, and molybdenum (10-100 times background) and weakly anomalous concentrations of copper, lead, sulfate, and zinc (2-10 times background) were found in the ground-water system above the buried deposit. Alkaline waters, which predominate in the Neves-Corvo area and in most of the Portuguese Pyrite Belt, favor the solubility and mobility of the ore-associated elements antimony, arsenic, and molybdenum as complex anionic species, but these waters greatly diminish the solubility and mobility of other ore-related metals that form cationic species, such as copper, lead, and zinc. This relationship is illustrated by the chemistry of the mine water originating from below the ore zone (site 24), which had a $\mathrm{pH}$ of 9.1 and contained $120 \mu \mathrm{g} / \mathrm{L}$ antimony, $90 \mu \mathrm{g} / \mathrm{L}$ arsenic, $16 \mu \mathrm{g} / \mathrm{L}$ molybdenum, but only normal to slightly elevated levels of copper $(6 \mu \mathrm{g} / \mathrm{L})$, lead $(0.3 \mu \mathrm{g} / \mathrm{L})$, and zinc 
$(2 \mu \mathrm{g} / \mathrm{L})$. In contrast, the sample of water collected from a well in the area of near-surface mineralized chert and sulfide-bearing manganese occurrences (site 23) had a $\mathrm{pH}$ of 6.7 and contained highly anomalous concentrations of copper $(160 \mu \mathrm{g} / \mathrm{L})$, lead $(29 \mu \mathrm{g} / \mathrm{L})$, and zinc $(400 \mu \mathrm{g} / \mathrm{L})$, but only normal concentrations of antimony $(0.1 \mu \mathrm{g} / \mathrm{L})$, arsenic $(<1$ $\mu \mathrm{g} / \mathrm{L})$, and molybdenum $(0.1 \mu \mathrm{g} / \mathrm{L})$. These facts underscore the importance in hydrogeochemical exploration studies of knowing the ore-associated elements, understanding the fundamental chemical controls that may affect trace-element solubility and mobility, and having the ability to measure these elements at very low concentrations by sensitive multielement analytical techniques.

The results of the hydrogeochemical study in the Neves-Corvo area indicate that ground water in contact with the buried massive sulfide mineral deposit is solubilizing and dispersing several of the ore-related elements, especially antimony, arsenic, and molybdenum, into the local groundwater system. The dispersion patterns of these elements define anomalous areas associated with the buried massive sulfide deposit at Neves-Corvo, and the patterns demonstrate the potential use of hydrogeochemical techniques in exploration programs for concealed massive sulfides in the Portuguese Pyrite Belt and in other geologically favorable areas.

\section{GEOCHEMICAL STUDIES IN AREAS OF POSITIVE GRAVITY ANOMALIES}

Biogeochemical and hydrogeochemical sampling was carried out in July and August of 1988 in several areas of southern Portugal where earlier geophysical studies had delineated strong, positive gravity anomalies. Samples of oak leaves and well water from these areas were collected, prepared, and analyzed by procedures previously described in this report. These studies were undertaken to determine if biogeochemical and hydrogeochemical data would help to evaluate and interpret these gravity anomalies in the search for concealed ore deposits in the Portuguese Pyrite Belt. Sampling time was limited to one day for each of these four anomalous areas, and, as a result, these studies are considered to be preliminary in nature.

\section{SALGADINHO STUDY AREA}

The Salgadinho study area is located in the Cercal-Salgadinho region of the PPB (fig. 1). This area contains buried volcanogenic disseminated sulfide mineral deposits in felsic volcanic rocks that have been investigated by diamond drilling in recent years and found to contain subeconomic amounts of copper, gold, lead, silver, and zinc. Narrow zones were found that contained as much as $16 \mathrm{ppm}$ gold and 80 ppm silver in drill-core samples. Sulfide minerals consist

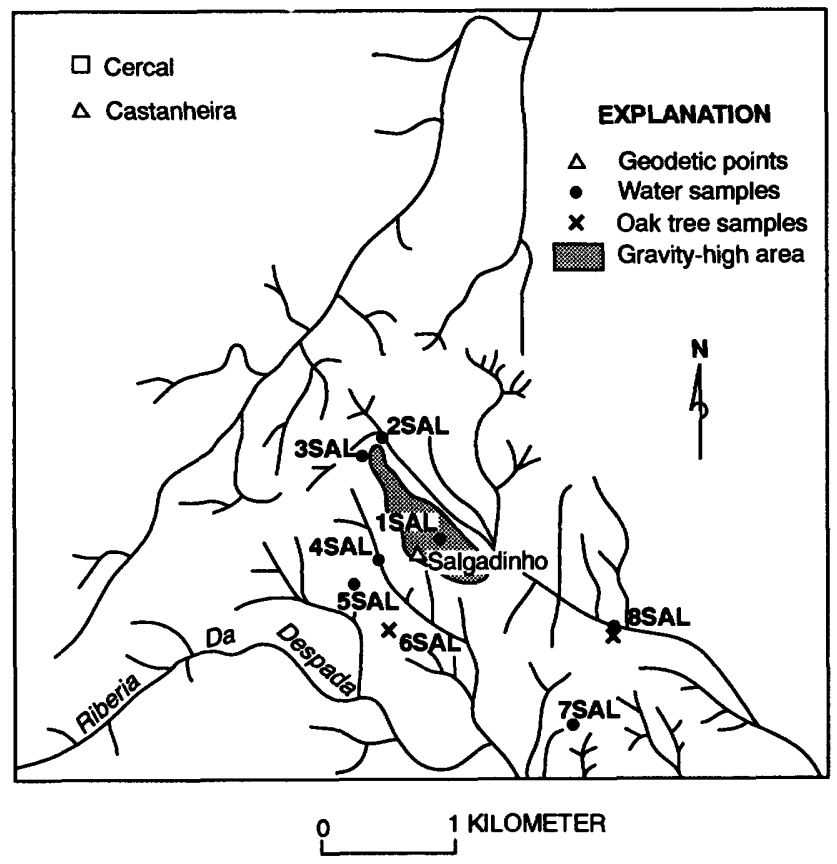

Figure 22. Water and oak tree sample localities, Salgadinho area, southern Portugal. Numbers (i.e., 8SAL) indicate sites at which water and (or) oak tree samples were collected. Open square indicates town.

primarily of pyrite and local concentrations of chalcopyrite, sphalerite, tetrahedrite, and galena. The geology, mineralogy, and alteration at Salgadinho is discussed in detail by Plimer and Carvalho (1982).

Samples of leaves from Cork oak trees (Quercus suber) at 3 sample sites and water from 8 wells were collected during August of 1988 at localities above and around the gravity high at Salgadinho (fig. 22). Analytical results for selected elements in the water samples and in the ash of the Cork oak leaves from this area are listed in tables 6 and 7.

Anomalous amounts of antimony, arsenic, and molybdenum were found in a water sample collected from a well at sample site $1 \mathrm{SAL}$, approximately $130 \mathrm{~m}$ to the east of the Salgadinho geodetic point (fig. 22). The water from this site was alkaline $(\mathrm{pH}=7.4)$, which favors the solubility and mobility of antimony, arsenic, and molybdenum as complex anions. Well water from site $2 \mathrm{SAL}$ was acidic $(\mathrm{pH}=6.1)$ and contained anomalous concentrations of copper and zinc, and water from site 3SAL had a very low pH (4.7) and contained high concentrations of zinc and detectable gold. The low $\mathrm{pH}$ of these water samples, which probably resulted from the release of hydrogen ions $\left(\mathrm{H}^{+}\right)$to the ground-water system as a result of oxidation of sulfides, favors the solubility and mobility of copper and zinc as cations. Dissolution of the sulfides may also cause the release of small amounts of gold to the ground water, resulting in the gold anomaly at site 3SAL. Anomalous concentrations of zinc and low $\mathrm{pH}$ values were also found in water samples from wells at sites 7SAL and 8SAL in an area $1 \mathrm{~km}$ southeast of the Salgadinho 
Table 6. Selected analytical results for water samples from geochemical study areas, southern Portugal.

[Values preceded by " $<$ " indicate that the element was not detected at the lower limit of determination shown]

\begin{tabular}{|c|c|c|c|c|c|c|c|c|}
\hline $\begin{array}{l}\text { Sample } \\
\text { number }\end{array}$ & $\begin{array}{c}\mathrm{Au} \\
(\mathrm{ng} / \mathrm{L})\end{array}$ & $\begin{array}{c}\mathrm{Cr} \\
(\mu \mathrm{g} / \mathrm{L}) \\
\end{array}$ & $\begin{array}{c}\mathrm{Cu} \\
(\mu \mathrm{g} / \mathrm{L})\end{array}$ & $\begin{array}{c}\text { Mo } \\
(\mu \mathrm{g} / \mathrm{L})\end{array}$ & $\begin{array}{c}\mathrm{Pb} \\
(\mu \mathrm{g} / \mathrm{L})\end{array}$ & $\mathrm{pH}$ & $\begin{array}{c}\mathrm{Sb} \\
(\mu \mathrm{g} / \mathrm{L})\end{array}$ & $\begin{array}{c}\mathrm{Zn} \\
(\mu \mathrm{g} / \mathrm{L})\end{array}$ \\
\hline \multicolumn{9}{|c|}{ Salgadinho geochemical study area } \\
\hline 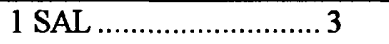 & $<1$ & 0.4 & 3 & 1.1 & 0.1 & 7.4 & 3.3 & 1 \\
\hline 2 SAL $\ldots \ldots \ldots \ldots \ldots \ldots \ldots \ldots \ldots \ldots \ldots$ & $<1$ & 0.4 & 5 & 0.1 & 0.2 & 6.1 & 0.1 & 25 \\
\hline $3 \mathrm{SAL} \ldots \ldots \ldots \ldots \ldots \ldots \ldots \ldots \ldots$ & 1 & 0.3 & 3 & $<0.1$ & 0.2 & 4.7 & 0.1 & 65 \\
\hline $4 \mathrm{SAL} \ldots \ldots \ldots \ldots \ldots \ldots \ldots \ldots \ldots \ldots$ & $<1$ & 0.4 & 3 & $<0.1$ & 0.4 & 5.6 & 0.1 & 8 \\
\hline $5 \mathrm{SAL} \ldots \ldots \ldots \ldots \ldots \ldots \ldots \ldots \ldots$ & $<1$ & 0.5 & 2 & $<0.1$ & 0.1 & 6.2 & 0.2 & 6 \\
\hline $7 \mathrm{SAL} \ldots \ldots \ldots \ldots \ldots \ldots \ldots \ldots \ldots \ldots \ldots$ & $<1$ & 0.5 & 2 & $<0.1$ & 0.2 & 5.7 & 0.1 & 31 \\
\hline $8 \mathrm{SAL} \ldots \ldots \ldots \ldots \ldots \ldots \ldots \ldots \ldots \ldots \ldots$ & $<1$ & 0.4 & 3 & $<0.1$ & 0.8 & 5.7 & 0.1 & 19 \\
\hline \multicolumn{9}{|c|}{ Garrochal-Almoleias geochemical study area } \\
\hline 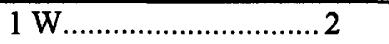 & & 0.5 & 3 & 0.7 & 4.0 & 7.0 & 0.1 & 3 \\
\hline 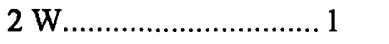 & & 0.6 & 3 & 0.1 & 3.8 & 5.7 & 0.2 & 8 \\
\hline 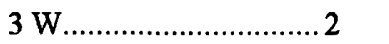 & & 0.5 & 6 & $<0.1$ & 3.9 & 6.3 & 0.3 & 10 \\
\hline $4 \mathrm{~W}$ & & 5.0 & 1 & 3.0 & 0.1 & 7.4 & 0.4 & 8 \\
\hline 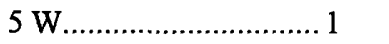 & $<1$ & 0.6 & 2 & 0.4 & 4.0 & 7.5 & $<0.1$ & 3 \\
\hline $6 \mathrm{~W} \ldots \ldots \ldots \ldots \ldots \ldots \ldots \ldots \ldots \ldots \ldots \ldots \ldots \ldots \ldots \ldots$ & $<1$ & 0.5 & 2 & 0.2 & 3.8 & 7.5 & $<0.1$ & 4 \\
\hline \multicolumn{9}{|c|}{ Cidrão geochemical study area } \\
\hline 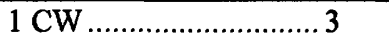 & & 0.4 & 2 & 3.0 & 3.0 & 7.6 & 0.3 & 5 \\
\hline $2 \mathrm{CW}$ & & 0.3 & 3 & 1.1 & 3.3 & 8.4 & 1.5 & 2 \\
\hline $3 \mathrm{CW}$ & $<1$ & 0.3 & 2 & 0.4 & 3.8 & 6.7 & 0.3 & 3 \\
\hline $4 \mathrm{CW}$ & & 1.3 & 3 & 2.0 & 3.7 & 8.3 & 3.0 & 7 \\
\hline $5 \mathrm{CW}$ & & 0.8 & 5 & 0.4 & 3.8 & 7.3 & 0.4 & 11 \\
\hline \multicolumn{9}{|c|}{ Mombeja geochemical study area } \\
\hline 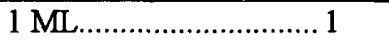 & $<1$ & 0.8 & 2 & 0.2 & 0.3 & 7.4 & $<0.1$ & 3 \\
\hline $2 \mathrm{ML}$ & 2 & 0.2 & 2 & 0.3 & 0.1 & 7.3 & 0.1 & 1 \\
\hline 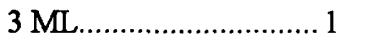 & $<1$ & 1.4 & 3 & 0.6 & 0.4 & 7.9 & 0.1 & 3 \\
\hline $4 \mathrm{ML} \ldots \ldots \ldots \ldots \ldots \ldots \ldots \ldots \ldots \ldots$ & $<1$ & 0.5 & 2 & 0.4 & 0.3 & 7.2 & $<0.1$ & 1 \\
\hline 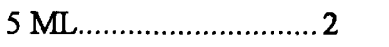 & $<1$ & 0.6 & 2 & 0.3 & $<0.1$ & 7.5 & 0.1 & 2 \\
\hline $6 \mathrm{ML} \ldots \ldots \ldots \ldots \ldots \ldots \ldots \ldots . . . . . . . . . . . . . .1$ & $<1$ & 0.6 & 2 & 0.3 & 0.1 & 7.2 & 0.1 & 1 \\
\hline $7 \mathrm{ML} \ldots \ldots \ldots \ldots \ldots \ldots \ldots \ldots \ldots \ldots \ldots \ldots \ldots$ & $<1$ & 6.0 & 2 & 0.1 & 2.5 & 7.4 & 0.1 & 1 \\
\hline $8 \mathrm{ML} \ldots \ldots \ldots \ldots \ldots \ldots \ldots \ldots \ldots \ldots \ldots$ & $<1$ & 12.0 & 2 & 0.1 & 0.1 & 7.3 & 0.1 & $<1$ \\
\hline $9 \mathrm{ML}$ & & 8.0 & 2 & 0.3 & 1.4 & 7.9 & 0.1 & 2 \\
\hline $10 \mathrm{ML}$ & & 14.0 & 2 & 0.1 & 0.8 & 7.3 & 0.7 & 1 \\
\hline $11 \mathrm{ML}$ & $<1$ & 1.2 & 2 & 0.3 & 0.5 & 8.1 & 0.2 & 9 \\
\hline
\end{tabular}

gravity high. These anomalies may be related to an extension of the Salgadinho mineralized zone.

Anomalous concentrations of copper were found in the ash of leaves from Cork oak trees at sample sites 6SAL and 8SAL (fig. 22). High concentrations of lead were also found in oak leaves from sites $1 \mathrm{SAL}$ and 6SAL.

\section{DISCUSSION OF RESULTS- SALGADINHO STUDY AREA}

Analytical results for samples of Cork oak leaves and well water collected in the Salgadinho study area show biogeochemical and hydrogeochemical anomalies in an area of known disseminated sulfide deposits and in an area $1 \mathrm{~km}$ southeast of the known deposits. Where the ground water is acidic, the best geochemical pathfinder seems to be zinc in well water. Where the ground water is alkaline, antimony, arsenic, and molybdenum are found in anomalous concentrations associated with sulfide minerals. The zinc anomaly at site 8SAL may be related to ground water moving southeastward from the Salgadinho area. However, the zinc anomaly at site $7 \mathrm{SAL}$, which is stronger than that at site 8SAL, suggests an unknown mineralized source in this area and may warrant further study.

\section{GARROCHAL-ALMOLEIAS STUDY AREA}

The Garrochal-Almoleias study area is located $10 \mathrm{~km}$ southwest of Castro Verde (fig. 1) and is part of the Estação de Ourique-Neves volcanic lineament, along which occur 
Table 7. Selected analytical results for samples of ash from oak leaves from geochemical study areas, southern Portugal.

[Values preceded by " $<$ " indicate that the element was not detected at the lower limit of determination shown]

\begin{tabular}{|c|c|c|c|}
\hline $\begin{array}{l}\text { Sample } \\
\text { number }\end{array}$ & $\underset{\text { (ppm) }}{\mathrm{Cu}}$ & $\begin{array}{c}\mathrm{Pb} \\
(\mathrm{ppm})\end{array}$ & $\begin{array}{c}\mathrm{Zn} \\
\text { (ppm) }\end{array}$ \\
\hline \multicolumn{4}{|c|}{ Salgadinho geochemical study area } \\
\hline $1 \mathrm{SAL} \ldots \ldots \ldots \ldots<1$ & 160 & 24 & 480 \\
\hline $6 \mathrm{SAL} \ldots \ldots \ldots \ldots<1$ & 250 & 22 & 530 \\
\hline $8 \mathrm{SAL} \ldots \ldots \ldots \ldots 1$ & 340 & $<6$ & 470 \\
\hline \multicolumn{4}{|c|}{ Garrochal-Almoleias geochemical study area } \\
\hline $1 \mathrm{~L} \ldots \ldots \ldots \ldots \ldots \ldots \ldots \ldots$ & 260 & 12 & 440 \\
\hline $2 \mathrm{~L} \ldots \ldots \ldots \ldots \ldots \ldots 1$ & 190 & 13 & 310 \\
\hline $3 \mathrm{~L} \ldots \ldots \ldots \ldots \ldots \ldots \ldots \ldots$ & 130 & 28 & 340 \\
\hline $4 \mathrm{~L} \ldots \ldots \ldots \ldots \ldots . . . .<1$ & 160 & 11 & 320 \\
\hline $5 \mathrm{~L} \ldots \ldots \ldots \ldots \ldots \ldots 1$ & 190 & 14 & 520 \\
\hline $6 \mathrm{~L} \ldots \ldots \ldots \ldots \ldots \ldots \ldots \ldots$ & 170 & 8 & 420 \\
\hline $7 \mathrm{~L} \ldots \ldots \ldots \ldots \ldots \ldots<1$ & 130 & 8 & 300 \\
\hline $8 \mathrm{~L} \ldots \ldots \ldots \ldots \ldots \ldots 1$ & 170 & 17 & 300 \\
\hline $9 \mathrm{~L} \ldots \ldots \ldots \ldots \ldots \ldots 1$ & 140 & 9 & 330 \\
\hline $10 \mathrm{~L} \ldots \ldots \ldots \ldots \ldots<1$ & 150 & 11 & 350 \\
\hline \multicolumn{4}{|c|}{ Cidrão geochemical study area } \\
\hline $1 \mathrm{CL} \ldots \ldots \ldots \ldots \ldots 1$ & 120 & 10 & 370 \\
\hline $2 \mathrm{CL} \ldots \ldots \ldots \ldots \ldots 1$ & 150 & 24 & 470 \\
\hline $3 \mathrm{CL} \ldots \ldots \ldots \ldots<1$ & 160 & 36 & 570 \\
\hline $4 \mathrm{CL} \ldots \ldots \ldots \ldots \ldots 1$ & 150 & 17 & 420 \\
\hline
\end{tabular}

the major sulfide deposits of Neves-Corvo. The rocks in the study area belong to the Volcanic Siliceous Complex and include felsic volcanic rocks, spilites, diabase sills, and siliceous shales. Although the results of drilling did not, as yet, prove the existence of mineral deposits, the potential of this target remains to be fully evaluated.

Samples of leaves from Cork oak trees $(Q$. suber $)$ at 10 sample sites and water from six wells were collected during July of 1988 in the vicinity of the high gravity areas (fig. 23). Analytical results for selected elements in water samples and in the ash of Cork oak leaves from this area are listed in tables 6 and 7. Anomalous concentrations of copper, lead, and zinc were found in a water sample collected from a well at sample site $3 \mathrm{~W}$, approximately $1 \mathrm{~km}$ northwest of the Almoleias geodetic point (fig. 23). The water from this site had a pH of 6.3, which favors the dissolution and mobility of copper, lead, and zinc. A water sample from a well at site $2 \mathrm{~W}$ also had a low $\mathrm{pH}$ (5.7) and contained $3.8 \mu \mathrm{g} / \mathrm{L}$ lead but only background concentrations of copper and zinc. Anomalous concentrations of antimony, arsenic, chromium, and molybdenum were measured in a water sample from a well at site $4 \mathrm{~W}$, approximately 0.5 $\mathrm{km}$ west of a small gravity anomaly. The high chromium value in the water at this site may be due to the dissolution of this metal from weathering of exposed mafic sills that are present in the area. However, the reason for the antimony, arsenic, and molybdenum anomalies at this site is unknown.

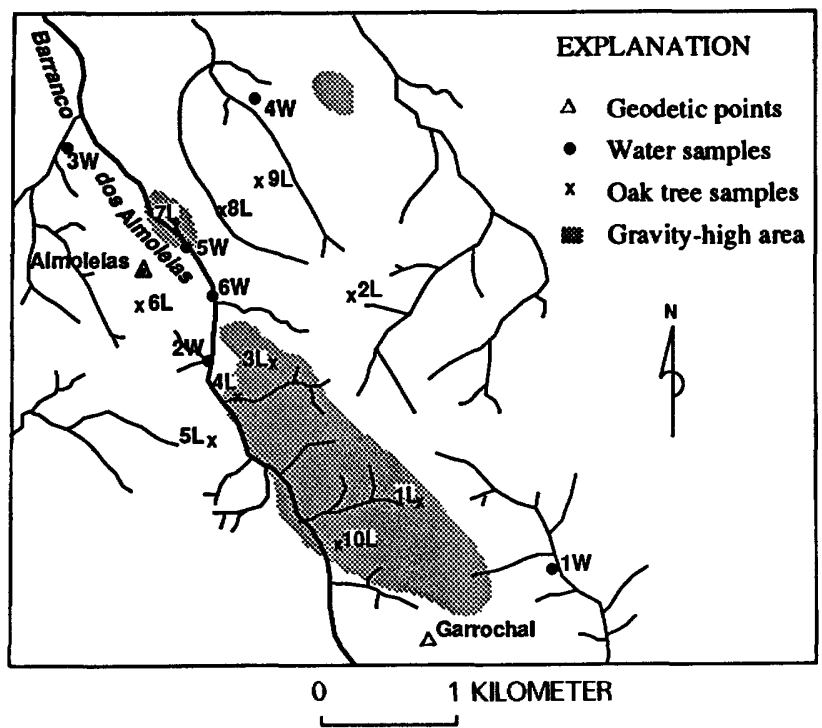

Figure 23. Water and oak tree sample localities, Garrochal-Almoleias area, southern Portugal. Numbers (i.e., 9L, 6W) indicate sites at which water or oak tree samples were collected.

Anomalous concentrations of copper in the ash of Cork oak leaves was found at site $1 \mathrm{~L}$, and leaves from an oak tree at site 3L contained anomalous concentrations of lead. Both of these sample locations are on hills within the large gravity anomaly north of the Garrochal geodetic point. No vegetation samples in this study area contained detectable concentrations of arsenic.

\section{DISCUSSION OF RESULTS- GARROCHAL-ALMOLEIAS STUDY AREA}

Analytical results on samples of Cork oak leaves and ground water collected in the Garrochal-Almoleias study area revealed two multielement hydrogeochemical anomalies. The cause of the copper, lead, and zinc anomaly in the water from site $3 \mathrm{~W}$ is unknown; however, the low $\mathrm{pH}$ of the sample suggests that the oxidation of sulfides with subsequent release of hydrogen ions to the ground water may be responsible. Based on the topographic relief in this area, the direction of ground-water flow to this site is likely from the south or southwest, and detailed geochemical studies in this area may help in revealing the cause of this anomaly. The second multielement hydrogeochemical anomaly is from a well sample at site $4 \mathrm{~W}$. The water at this location contains relatively high concentrations of antimony, arsenic, and molybdenum and a pH of 7.4. The source of this anomaly is also unknown; however, the probable direction of ground-water flow to this site is from the east and southeast, from an area containing a positive gravity anomaly. Detailed geochemical studies around this gravity high may provide additional information on the source of this 


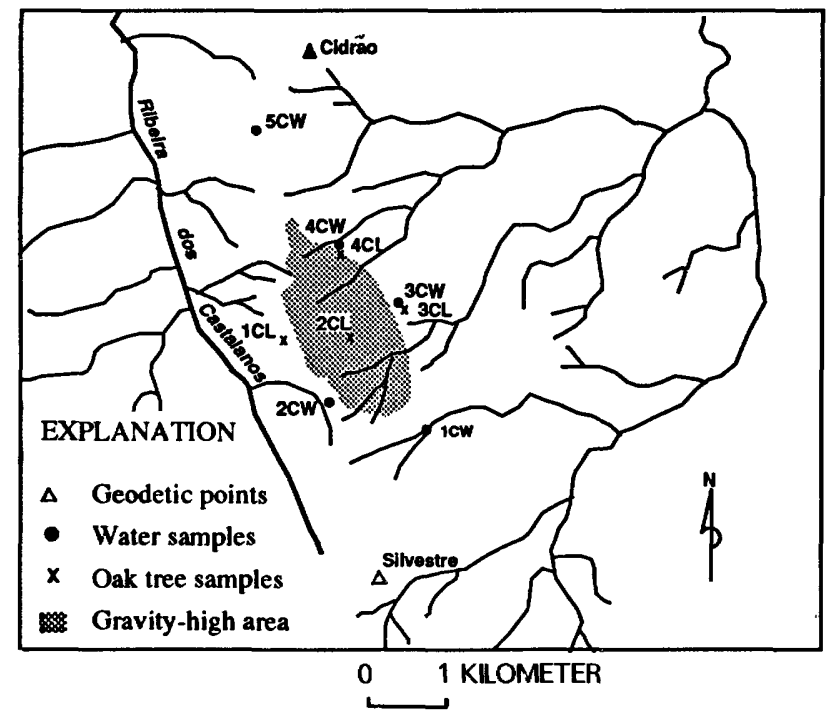

Figure 24. Water and oak tree sample localities, Cidrão area, southern Portugal. Numbers (i.e., $2 \mathrm{CL}, 4 \mathrm{CW}$ ) indicate sites at which water and (or) oak tree samples were collected.

antimony, arsenic, and molybdenum hydrogeochemical anomaly. Five of the six water samples collected in this area contained lead in concentrations greater than $3.8 \mu \mathrm{g} / \mathrm{L}$. These high lead concentrations may be a result of higher local background for lead.

\section{CIDRÃO STUDY AREA}

The Cidrão study area is located in the northwestern part of the Portuguese Pyrite Belt, near Grandola (fig. 1). The rocks in the study area correspond to the distal or terminal facies of the Volcanic Siliceous Complex and include tuffites, siliceous shales, and black shales. Shales and graywackes of the Culm Group are also present in the area. A gravity anomaly in this area was investigated by drilling in recent years without finding any evidence of mineral deposits. The explanation for the gravity anomaly in this area remains an open question.

Samples of leaves from Cork oak trees ( $Q$. suber) at four sample sites and water samples from five wells were collected during August of 1988 in the vicinity of the gravity high, approximately $3 \mathrm{~km}$ south of the Cidrão geodetic point (fig. 24). Analytical results for selected elements in water samples and in the ash of oak leaves from this study area are listed in tables 6 and 7.

Anomalous concentrations of antimony, arsenic, and molybdenum were found in water samples collected from wells at sample sites $2 \mathrm{CW}$ and $4 \mathrm{CW}$, and a water sample from site $1 \mathrm{CW}$ contained anomalous arsenic and molybdenum. These ground-water samples were all alkaline, with $\mathrm{pH}$ values ranging from 7.6 to 8.4 . Water collected from a well at site $5 \mathrm{CW}$, located $1 \mathrm{~km}$ southwest of the Cidrão geodetic point, contained $5 \mu \mathrm{g} / \mathrm{L}$ copper, $3.8 \mu \mathrm{g} / \mathrm{L}$ lead, and $11 \mu \mathrm{g} / \mathrm{L}$ zinc. Anomalous concentrations of lead and zinc were measured in the ash of oak leaves collected from site 3CL. A water sample collected from a well at site $3 \mathrm{CW}$ had a $\mathrm{pH}$ of 6.7. All of the water samples collected in the Cidrão area contained lead in excess of $3.0 \mu \mathrm{g} / \mathrm{L}$, which may indicate a high local background concentration for lead.

\section{DISCUSSION OF RESULTS-CIDRÃO STUDY AREA}

Analytical results on samples of Cork oak leaves and well water collected in the Cidrão study area indicate hydrogeochemical and biogeochemical anomalies in the area of a gravity high. Ground water in the gravity-high area contains anomalous concentrations of antimony, arsenic, and molybdenum at several sites, and water from a well located $1.5 \mathrm{~km}$ north of the gravity area contains high copper, lead, and zinc. High concentrations of lead and zinc were also measured in oak leaves from a site on the east edge of the gravity high. The source of these anomalies is unknown, but they could be related to water-rock reactions involving buried mineral deposits. Additional water sampling at lower elevations around this anomaly, where contributions from a deeper ground-water source are available, may help answer this question.

\section{MOMBEJA STUDY AREA}

An additional study was conducted in the Mombeja area, which is located immediately to the north of the PPB, approximately $25 \mathrm{~km}$ west of Beja in south-central Portugal (fig. 1). The Mombeja study area is underlain by mafic to ultramafic rocks consisting of amphibolite, gabbro, serpentinite, and listwaenite (altered serpentinite). These rocks are intruded locally by plagiogranite. The listwaenites consist primarily of quartz, ankerite, and chromium muscovite (fuchsite or mariposite); they are important hosts for gold deposits.

Samples of ground water were collected from 11 wells during August of 1988 along a northwest-trending alignment of listwaenite outcrops and around a gravity high located 4 $\mathrm{km}$ east of the town of Mombeja (fig. 25). Analytical results for selected elements in the water samples from this study area are listed in table 6.

Anomalous concentrations of chromium, ranging from 6 to $14 \mu \mathrm{g} / \mathrm{L}$, were found in water samples from wells at sample sites $7 \mathrm{ML}, 8 \mathrm{ML}, 9 \mathrm{ML}$, and $10 \mathrm{ML}$ in an area around this gravity high. At sample site $2 \mathrm{ML}$, in an area with exposed listwaenite, the well water contained detectable amounts of gold.

\section{DISCUSSION OF RESULTS-MOMBEJA STUDY AREA}

Analytical results on samples of well water collected in the Mombeja study area indicate that high concentrations of chromium are present in the ground-water system around the 


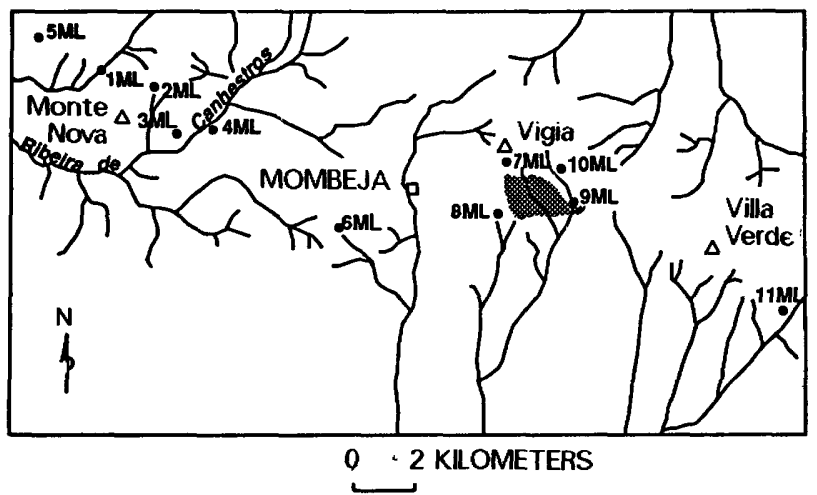

\section{EXPLANATION}

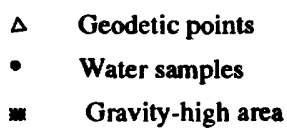

Figure 25. Water sample localities, Mombeja area, southern Portugal. Numbers (i.e., 6ML) indicate sites at which water samples were collected. Open square indicates town.

gravity anomaly east of town. The chromium anomaly may be from water-rock reactions involving buried mafic and ultramafic rocks and suggests that the gravity high in this area may be related to unexposed rocks of similar composition. The cause of the anomalous gold concentration in the water sample collected from a well at location $2 \mathrm{ML}$ is not known, but it could be related to local occurrences of gold associated with listwaenites. Additional geochemical investigations in this area could help explain this high gold value.

\section{CONCLUSIONS}

The exploration geochemical studies conducted at Neves-Corvo and other selected localities in and near the Portuguese Pyrite Belt indicate that surface geochemical sampling methods combined with sensitive multielement analytical techniques can be used to detect concealed polymetallic massive sulfide deposits.

Analytical results of the selective leaching of the crystalline Fe-oxide and Mn-oxide-amorphous Fe-oxide fractions of rocks and soils in the Neves-Corvo area appear to delineate anomalies spatially associated with known nearsurface sulfide deposits. The anomalies are more intense in the rock leachates as compared to soil leachates, especially for arsenic, copper, and molybdenum. Significant leachate anomalies were not found in rock and soil samples collected over the deeper massive sulfide bodies of Neves and Corvo, particularly in areas covered by shales and graywackes. This suggests that leachate geochemistry may be most useful in the PPB for exploration for near-surface mineral deposits or in defining lithologies favorable for hosting massive sulfide deposits.
Analytical results on samples of vegetation collected in the Neves-Corvo area delineate several anomalous areas, some of which are associated with known buried massive sulfide deposits. The highest concentrations of ore-related elements, such as antimony, arsenic, bismuth, copper, indium, and tin, were found in the first-year growth of leaves and stems of Holm oak (Quercus ilex). Optimum biogeochemical response for ore-associated elements occurred in samples collected during the active growing season (July-August) and from trees that had trunk diameters greater than $15 \mathrm{~cm}$. The best overall biogeochemical indicator of sulfides in the Neves-Corvo study area seems to be arsenic in the ash of Holm oak leaves, possibly resulting from the high mobility of this element in the subsurface environment and unique translocation mechanisms in Holm oak trees. The results of the biogeochemical study in the NevesCorvo area indicate that biogeochemical exploration methods, specifically the sampling and analysis of the first-year growth of oak trees during the active growing season, may be useful to exploration programs in the PPB in the search for concealed massive sulfide deposits.

Analytical results by ICP-MS and other sensitive analytical techniques on samples of water collected from open wells and pumping wells in the Neves-Corvo area show anomalous hydrogeochemical dispersion patterns associated with subsurface massive sulfide bodies. Strongly anomalous concentrations of antimony, arsenic, and molybdenum (10-100 times background) and weakly anomalous concentrations of copper, lead, sulfate, and zinc (2-10 times background) were found in the ground-water system above the buried deposit. Alkaline waters, which predominate in the Neves-Corvo area and in most of the PPB, favor the solubility and mobility of the ore-associated elements antimony, arsenic, and molybdenum as complex anionic species, but these waters greatly diminish the solubility and mobility of other ore-related metals that form cationic species, such as copper, lead, and zinc. The results of the hydrogeochemical study in the Neves-Corvo area indicate that ground water in contact with the buried massive sulfide mineral deposit is solubilizing and dispersing several of the ore-related elements, especially antimony, arsenic, and molybdenum, into the local ground-water system. The dispersion patterns of these elements define anomalous areas associated with the buried massive sulfide deposit at Neves-Corvo, and the patterns demonstrate the potential use of hydrogeochemical techniques in exploration programs for concealed massive sulfides in the Portuguese Pyrite Belt and in other geologically favorable areas.

Acknowledgments. - This study was funded principally by the Luso American Development Foundation, who we gratefully acknowledge. Other financial, technical, and logistical support was provided by the U.S. Geological Survey (USGS), the Serviços Geológicos de Portugal (SGP), and the Serviços de Formento Mineiro (SFM). 
Special thanks go to Robert Earhart (USGS), Jose Oliveira (SGP), and Vitor Oliveira (SFM) for their assistance in field orientation and sampling. Thanks are also extended to the mining company, Somincor, for allowing geochemical samples to be collected at Neves-Corvo. We especially acknowledge the assistance and hospitality provided by David Richards and Pedro Carvalho, geologists employed by Somincor.

The authors are grateful for the analytical assistance given by Walter Ficklin, Allen Meier, Jerry Motooka, and Richard Sanzolone of the Branch of Geochemistry, USGS.

\section{REFERENCES CITED}

Baedeker's Portugal, 1968, Englewood Cliffs, New Jersey, Prentice Hall Inc., 264 p.

Boyle, R.W., Hornbrook, E.H.W., Allan, R.J., Dyck, Willy, and Smith, A.V., 1971, Hydrogeochemical methods-Applications in the Canadian shield: Bulletin of the Canadian Institute of Mining and Metallurgy, v. 64, p. 60-71.

Bradshaw, P.M.D., Thomson, Ian, Smee, B.W., and Larsson, J.O., 1974, The application of different analytical extractions and soil profile sampling in exploration geochemistry: Journal of Geochemical Exploration, v. 3, p. 209-225.

Britton, H.T.S., 1955, Hydrogen Ions (4th ed.): London, Chapman and Hall, $187 \mathrm{p}$.

Brooks, R.R., 1972, Geobotany and Biogeochemistry in Mineral Exploration: New York, Harper and Row, 290 p.

Carvalho, D., 1991, Case history of the Neves-Corvo massive sulfide deposit, Portugal, and implications for future discoveries, in Grauch, R.I., and Hutchinson, R.W., eds., Mineral Deposit Research, Symposium at the Geological Society of America Centennial Meeting: Monograph 8, Society of Economic Geolologists, p. 314-334.

Carvalho, D., Conde, L., Enrile, J.H., Oliveira, V., and Schermerhorn, L.J.G.S., 1976, Livro-Guia das excursões geologicas na Faixa Piritosa Ibérica: Comunicações dos Serviços Geológicos de Portugal, v. 60, p. 271-315.

Chao, T.T., 1984, Use of partial dissolution techniques in geochemical exploration: Journal of Geochemical Exploration, v. 20, p. 101-135.

Chao, T.T., and Theobald, P.K., 1976, The significance of secondary iron and manganese oxides in geochemical exploration: Economic Geology, v. 71, p. 1560-1569.

Crone, W.W., Larson, L.T., Carpenter, R.H., Chao, T.T., and Sanzolone, R.F., 1984, A comparison of iron oxide-rich joint coatings and rock chips as geochemical sampling media in exploration for disseminated gold deposits: Journal of Geochemical Exploration, v. 20, p. 161-178.

Fernandez-Rubio, Rafael, Carvalho, Pedro, and Real, Fernando, 1988, Mining-hydrological characteristics of the underground copper mine of Neves Corvo, Portugal: Third International Mine Water Congress, Melbourne, Australia, 1988, 15 p.
Filipek, L.H., and Theobald, P.K. Jr., 1981, Sequential extraction techniques applied to a porphyry copper deposit in the Basin and Range Province: Journal of Geochemical Exploration, v. 14, p. 155-174.

Fishman, M.J., and Pyen, Grace, 1979, Determination of selected anions in water by ion chromatography: U.S. Geological Survey Water Resources Investigations 79-101, $30 \mathrm{p}$.

Humphries, C.J., Press, J.R., and Sutton, D.A., 1985, Trees of Britain and Europe: Feltham, Middlesex, England, Hamlin Publishing Group Limited, $320 \mathrm{p}$.

Kovalevskii, A.L., 1974, Biogeochemical Exploration for Mineral Deposits: Moscow, Nedra Publishers, 136 p.

Leavitt, S.W., and Goodell, H.G., 1979, Evaluation of biogeochemical prospecting methods in the search for sulfide deposits in the Appalachian Piedmont, Virginia, USA: Journal of Geochemical Exploration, v. 11, p. 89-100.

Levinson, A.A., 1974, Introduction to Exploration Geochemistry: Maywood, Ill., Applied Publishing Ltd., 612 p.

Lichte, F.E., Meier, A.L., and Crock, J.G., 1987, Determination of the rare earth elements in geological materials by inductively coupled plasma mass spectrometry: Analytical Chemistry, v. 59 , no. 8, p. 1150-1157.

McHugh, J.B., 1986, Determining gold in water by ion-exchange batch extraction: Talanta, v. 33, p. 349-351.

Miesch, A.T., 1976, Geochemical survey of Missouri-Methods of sampling, laboratory analysis, and statistical reduction of data: U.S. Geological Survey Professional Paper 954-A, 39 p.

Miller, W.R., 1979, Application of hydrogeochemistry to the search for base metals, in Hood P.J., ed., Special Volume, Pa. pers Given at Exploration 77, Ottawa: Canada Economic Geology Report 31, Geological Survey of Canada, p. 479-487.

Motooka, J.M., and Sutley, S.J., 1982, Analysis of oxalic leachates of geologic materials by inductively coupled plasma-atomicemission spectroscopy: Applied Spectroscopy, v. 36, p. 524-533.

Nunes, J.F., Richards, D.G., and Gama, H.A., 1990, Mine water and environmental protection-the Somincor case, in Norton, P.J., ed., International Symposium Lisboa 90-Acid Mine Water in Pyritic Environments, Lisbon, Portugal, p. 237-251.

Orion Research, Inc., 1978, Orion Research Analytical Guide (9th ed.): Cambridge, Mass., 48 p.

Perkin-Elmer Corporation, 1976, Analytical Methods for Atomic Absorption Spectrophotometry: Norwalk, Conn., Perkin-Elmer Corp., $586 \mathrm{p}$.

1977, Analytical Methods for Atomic Absorption Spectrophotometry Using the HGA Graphite Furnace: Norwalk, Conn., Perkin-Elmer Corp., 208 p.

Plimer, I.R., and Carvalho, D., 1982, The geochemistry of hydrothermal alteration at the Salgadinho copper deposit, Portugal: Berlin, Mineralium Deposita, v. 17, no. 2, p. 193-211.

Schermerhorn, L.J.G., 1970, The deposition of volcanics and pyritite in the Iberian Pyrite Belt: Berlin, Mineralium Deposita, v. 5 , no. 3, 273-279. 


\section{APPENDIX 1: SEQUENTIAL DISSOLUTION PROCEDURE USED IN THE NEVES-CORVO STUDY AREA}

Rock and soil samples collected along the traverse containing sample sites 20-28 (figs. 2 and 3) were initially subjected to a four-step sequential dissolution scheme modified from a procedure described by Chao (1984). This scheme was designed to solubilize and separate chemical phases of the samples in the following order: (1) Mn-oxides and amorphous Fe-oxides, (2) crystalline Fe-oxides, (3) sulfides and organics, and (4) the residue ("silicate fraction").

In step $1,25 \mathrm{~mL}$ of $0.25 \mathrm{M}$ hydroxylamine hydrochloride in $0.25 \mathrm{~N}$ hydrochloric acid $(\mathrm{HCl})$ were added to $1.0 \mathrm{~g}$ of sample and heated in a water bath at $50^{\circ} \mathrm{C}$ for 30 minutes. The samples were then centrifuged and decanted, with the leachate saved for analysis.

In step $2,25 \mathrm{~mL}$ of $4 \mathrm{~N} \mathrm{HCl}$ were added to the residual material from step 1 and heated in a water bath at $95^{\circ} \mathrm{C}$ for 30 minutes. The samples were centrifuged and decanted, with the leachate saved for analysis.

In step $3,2 \mathrm{~g}$ of potassium chlorate and $10 \mathrm{~mL}$ of concentrated $\mathrm{HCl}$ were added to the residual material from step
2. The samples were left to stand at room temperature for $\mathbf{4 5}$ minutes and then diluted with $15 \mathrm{~mL}$ of water. The samples were centrifuged and decanted, with the leachate saved for analysis.

In step $4,10 \mathrm{~mL}$ of concentrated nitric acid were added to $50-\mathrm{mL}$ Teflon beakers containing the residual material from step 3, and the resultant solutions were heated on a hot plate at $110^{\circ} \mathrm{C}$ for 10 minutes. Ten $\mathrm{mL}$ of perchloric acid and $10 \mathrm{~mL}$ of 48 percent hydrofluoric acid were added, and the sample solutions were heated on a hot plate at $220^{\circ} \mathrm{C}$ until a moist bead was obtained. Twenty-five $\mathrm{mL}$ of $4 \mathrm{~N} \mathrm{HCl}$ were added and the samples heated at $100^{\circ} \mathrm{C}$ for 30 minutes. The solutions were transferred to test tubes, centrifuged, and decanted, with the liquid saved for analysis.

A separate total digestion was performed on each of these samples with a fresh $0.5 \mathrm{~g}$ sample split using the same procedure as in step 4 in order to compare the "total" metal concentrations to the sum of the sequential dissolutions of steps 1-4. 


\section{APPENDIX 2: ANALYTICAL RESULTS OF SEQUENTIAL EXTRACTIONS OF ROCK SAMPLES FROM THE NEVES-CORVO AREA (SAMPLES 20-28)}

Appendix 2. Analytical results of sequential extractions of rock samples 20-28, Neves-Corvo area, southern Portugal.

[Analysis by inductively coupled plasma-emission spectrographic analysis of extracted fractions. See fig. 2 for sample locations. Values preceded by "<" indicate that the elemen was not detected at the lower limit of determination shown]

\begin{tabular}{|c|c|c|c|c|}
\hline $\begin{array}{l}\text { Sample } \\
\text { number }\end{array}$ & $\begin{array}{l}\text { Mn-oxides } \\
\text { and amorphic } \\
\text { Fe-oxides }\end{array}$ & $\begin{array}{l}\text { Crystalline } \\
\text { Fe-oxides }\end{array}$ & $\begin{array}{l}\text { Sulfides and } \\
\text { organics }\end{array}$ & Residue \\
\hline \multicolumn{5}{|c|}{ As (ppm) } \\
\hline 20 & $<3$ & $<3$ & $<3$ & $<3$ \\
\hline 21 & $<3$ & 11 & $<3$ & $<3$ \\
\hline 22 & $<3$ & 390 & 130 & 340 \\
\hline 23 & $<3$ & 28 & 8 & $<3$ \\
\hline 24 & $<3$ & 9 & $<3$ & $<3$ \\
\hline 25 & $<3$ & 10 & $<3$ & $<3$ \\
\hline 26 & $<3$ & 6 & $<3$ & $<3$ \\
\hline 27 & $<3$ & 5 & $<3$ & $<3$ \\
\hline 28 & $<3$ & 6 & $<3$ & $<3$ \\
\hline \multicolumn{5}{|c|}{ Cu (ppm) } \\
\hline 20 & 1 & 3 & $<1$ & $<1$ \\
\hline 21 & 2 & 15 & 1 & 2 \\
\hline 22 & 14 & 180 & 42 & 270 \\
\hline 23 & 3 & 67 & 14 & 18 \\
\hline 24 & 29 & 100 & 13 & 15 \\
\hline 25 & 2 & 33 & 4 & 1 \\
\hline 26 & 2 & 16 & 2 & 2 \\
\hline 27 & 1 & 10 & 1 & 3 \\
\hline 28 & 2 & 4 & $<1$ & $<1$ \\
\hline \multicolumn{5}{|c|}{$\mathrm{Fe}(\%)$} \\
\hline 20 & 0.03 & 0.29 & 0.01 & 0.01 \\
\hline 21 & 0.18 & 4.20 & 0.05 & 0.59 \\
\hline 22 & 0.07 & 11.00 & 1.70 & 7.90 \\
\hline 23 & 0.05 & 7.80 & 1.10 & 1.40 \\
\hline 24 & 0.10 & 3.30 & 0.50 & 1.10 \\
\hline 25 & 0.15 & 3.80 & 0.45 & 0.59 \\
\hline 26 & 0.23 & 4.50 & 0.37 & 0.25 \\
\hline 27 & 0.14 & 3.60 & 0.20 & 0.23 \\
\hline 28 & 0.09 & 0.56 & 0.02 & 0.03 \\
\hline \multicolumn{5}{|c|}{ Mn (ppm) } \\
\hline 20 & 14 & 21 & $<8$ & $<8$ \\
\hline 21 & 590 & 390 & 47 & 23 \\
\hline 22 & 25 & 22 & 16 & 51 \\
\hline 23 & $<8$ & 17 & $<8$ & 38 \\
\hline 24 & 4,900 & 600 & 48 & 92 \\
\hline 25 & 320 & 570 & 83 & 51 \\
\hline 26 & 90 & 370 & 32 & $<8$ \\
\hline 27 & 910 & 380 & 23 & $<8$ \\
\hline 28 & 460 & 200 & $<8$ & $<8$ \\
\hline
\end{tabular}

\begin{tabular}{|c|c|c|c|c|}
\hline $\begin{array}{l}\text { Sample } \\
\text { number }\end{array}$ & $\begin{array}{c}\text { Mn-oxides } \\
\text { and amorphic } \\
\text { Fe-oxides }\end{array}$ & $\begin{array}{l}\text { Crystalline } \\
\text { Fe-oxides }\end{array}$ & $\begin{array}{l}\text { Sulfides and } \\
\text { organics }\end{array}$ & Residue \\
\hline \multicolumn{5}{|c|}{ Mo (ppm) } \\
\hline 20 & $<1$ & $<1$ & $<1$ & $<1$ \\
\hline 21 & $<1$ & $<1$ & $<1$ & $<1$ \\
\hline 22 & $<1$ & 52 & 19 & 47 \\
\hline 23 & $<1$ & 2 & $<1$ & $<1$ \\
\hline 24 & $<1$ & 1 & $<1$ & $<1$ \\
\hline 25 & $<1$ & $<1$ & $<1$ & $<1$ \\
\hline 26 & $<1$ & $<1$ & $<1$ & $<1$ \\
\hline 27 & $<1$ & $<1$ & $<1$ & $<1$ \\
\hline 28 & $<1$ & $<1$ & $<1$ & $<1$ \\
\hline \multicolumn{5}{|c|}{ Na (ppm) } \\
\hline 20 & $<2$ & 3 & $<2$ & 330 \\
\hline 21 & $<2$ & 54 & $<2$ & 20,000 \\
\hline 22 & $<2$ & 47 & $<2$ & 1,100 \\
\hline 23 & $<2$ & 50 & $<2$ & 3,300 \\
\hline 24 & $<2$ & 54 & $<2$ & 1,300 \\
\hline 25 & $<2$ & 72 & $<2$ & 12,000 \\
\hline 26 & $<2$ & 78 & $<2$ & 17,000 \\
\hline 27 & $<2$ & 71 & $<2$ & 16,000 \\
\hline 28 & $<2$ & 48 & $<2$ & 150 \\
\hline \multicolumn{5}{|c|}{$\mathrm{Pb}$ (ppm) } \\
\hline 20 & $<5$ & $<5$ & $<5$ & $<5$ \\
\hline 21 & $<5$ & 7 & $<5$ & $<5$ \\
\hline 22 & 21 & 150 & 18 & 49 \\
\hline 23 & $<5$ & 10 & $<5$ & 65 \\
\hline 24 & $<5$ & $<5$ & $<5$ & $<5$ \\
\hline 25 & $<5$ & $<5$ & $<5$ & $<5$ \\
\hline 26 & 8 & 8 & $<5$ & $<5$ \\
\hline 27 & 7 & $<5$ & $<5$ & $<5$ \\
\hline 28 & $<5$ & $<5$ & $<5$ & $<5$ \\
\hline \multicolumn{5}{|c|}{ Zn (ppm) } \\
\hline 20 & $<1$ & 4 & 1 & $<1$ \\
\hline 21 & 6 & 53 & 8 & 9 \\
\hline 22 & 1 & 16 & 4 & 29 \\
\hline 23 & 1 & 15 & 3 & 4 \\
\hline 24 & 3 & 32 & 6 & 12 \\
\hline 25 & 3 & 50 & 8 & 8 \\
\hline 26 & 8 & 67 & 6 & 3 \\
\hline 27 & 3 & 55 & 4 & 3 \\
\hline 28 & 1 & 6 & 1 & 1 \\
\hline
\end{tabular}




\section{APPENDIX 3: ANALYTICAL RESULTS OF SEQUENTIAL EXTRACTIONS OF SOIL SAMPLES FROM THE NEVES-CORVO AREA (SAMPLES 20-28)}

Appendix 3. Analytical results of sequential extractions of soil samples 20-28, Neves-Corvo area, southern Portugal.

[Analysis by inductively coupled plasma-emission spectrographic analysis of extracted fractions. See fig. 3 for sample locations. Values preceded by "<" indicate that the element was not detected at the lower limit of determination shown]

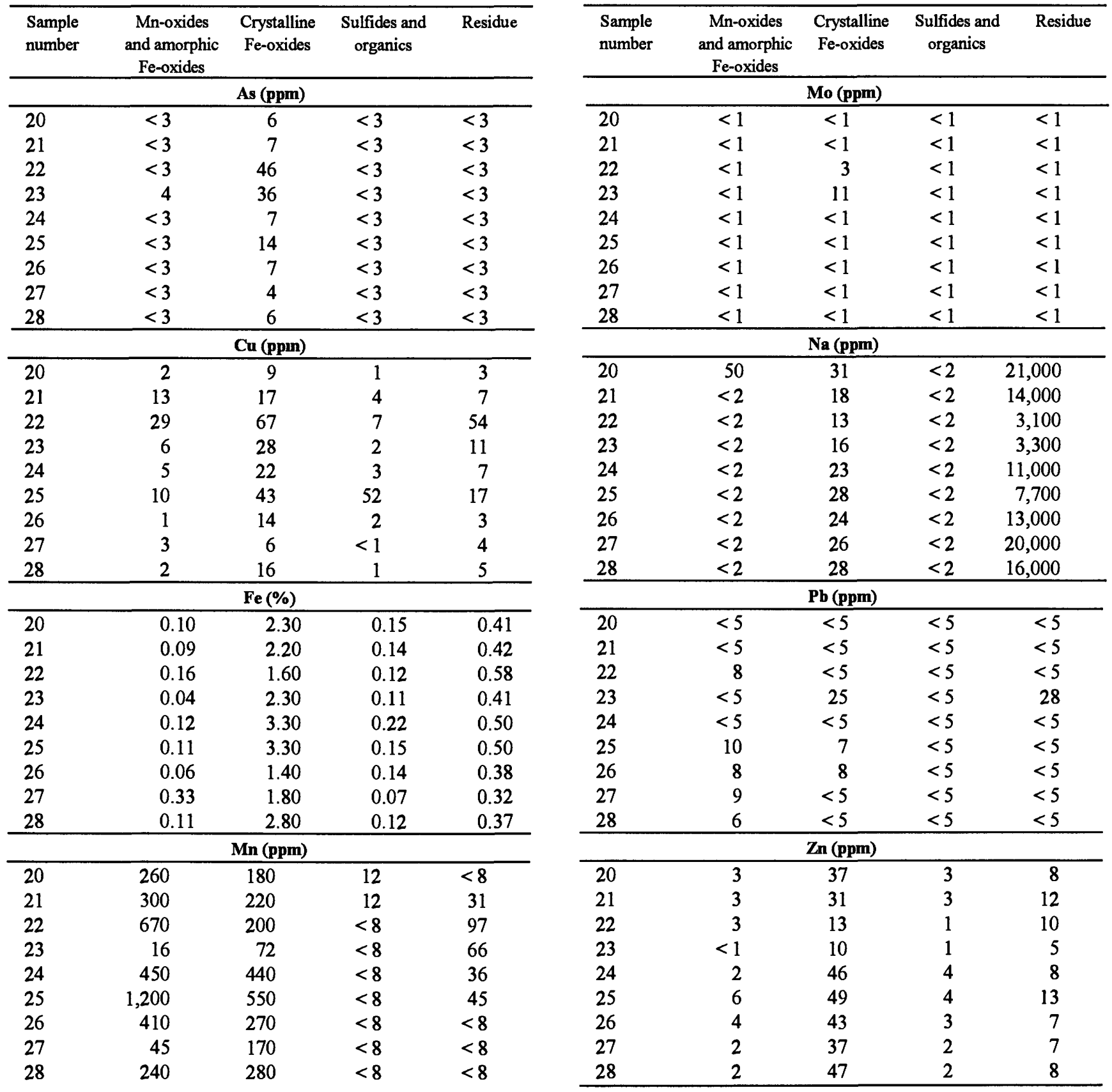






